UNIVERSIDAD DE SALAMANCA

INSTITUTO DE NEUROCIENCIAS DE CASTILLA Y LEÓN

LABORATORIO DE NEUROFISIOLOGÍA DE LA AUDICIÓN

\title{
FUNCTIONAL MECHANISMS OF STIMULUS-SPECIFIC ADAPTATION IN NEURONS OF THE AUDITORY THALAMUS AND ITS CORTICAL MODULATION
}
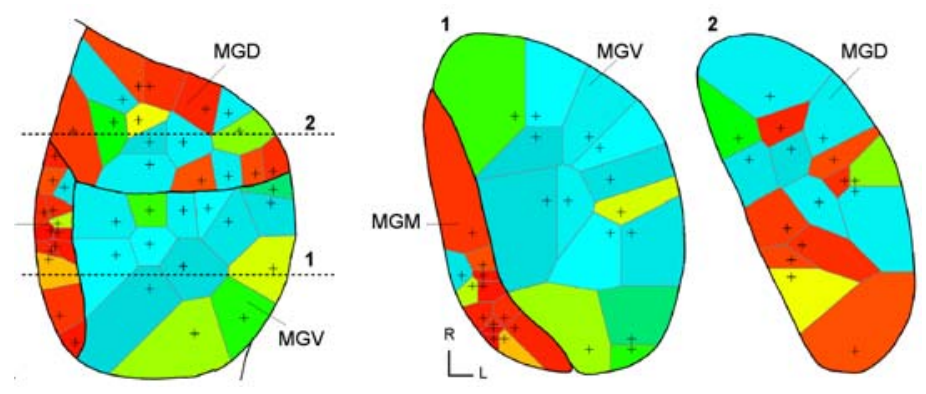

Flora Maria Ferreira Antunes

Salamanca, May 2011 


\title{
UNIVERSIDAD DE SALAMANCA INSTITUTO DE NEUROCIENCIAS DE CASTILLA Y LEÓN LABORATORIO DE NEUROFISIOLOGÍA DE LA AUDICIÓN Doctoral Program in Neurosciences
}

\section{FUNCTIONAL MECHANISMS OF STIMULUS-SPECIFIC ADAPTATION IN NEURONS OF THE AUDITORY THALAMUS AND ITS CORTICAL MODULATION}

\author{
Thesis submitted for the degree of \\ Doctor in Neurosciences and Doctor Europeus
}

By

Flora Maria Ferreira Antunes

This work was carried out under the supervision of

Prof. Dr. Manuel Sánchez Malmierca

Salamanca, May 2011 
MANUEL SÁNCHEZ MALMIERCA, PROFESOR TITULAR DE UNIVERSIDAD DEL DEPARTAMENTO DE BIOLOGÍA CELULAR Y PATOLOGÍA DE LA UNIVERSIDAD DE SALAMANCA E INVESTIGADOR DEL INSTITUTO DE NEUROCIENCIAS DE CASTILLA Y LEÓN

\section{CERTIFICA}

Que la tesis doctoral titulada:

\section{FUNCTIONAL MECHANISMS OF STIMULUS-SPECIFIC ADAPTATION IN NEURONS OF THE AUDITORY THALAMUS AND ITS CORTICAL MODULATION}

ha sido redactada en inglés, contiene un resumen en español de más de 25 páginas, y describe el trabajo de investigación realizado por Dña. Flora Maria Ferreira Antunes bajo mi dirección durante los últimos 4 años.

La memoria de este estudio recoge un análisis detallado y exhaustivo de los mecanismos de adaptación específicos a estímulos en el tálamo auditivo y su modulación cortical. Los datos presentados en esta memoria constituyen una aportación original y puedo afirmar que ponen de manifiesto un gran avance y progreso en el área de las Neurociencias.

Por todo ello, considero que esta tesis reúne la calidad y rigor científicos necesarios para que sea defendida en la Universidad de Salamanca como requisito para que Dña. Flora Maria Ferreira Antunes opte a los grados de 'Doctor' y 'Doctor Europeus’ por la Universidad de Salamanca.

Y para que as conste, firmamos el presente certificado en Salamanca a 18 de Mayo de 2010.

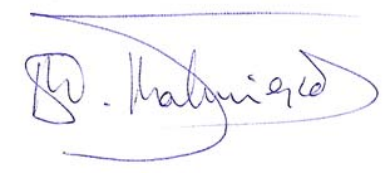


... à parte disso, tenho em mim todos os sonhos do mundo.

Álvaro de Campos (Fernando Pessoa). A Tabacaria, 1928. 
This work has been supported by a fellowship from the Spanish Ministry of Education and Science (MEC; BES-2007-15642), a fellowship for short visits to other R \& D centres of the sub-program FPI-MICINN (Spanish Ministry of Science and Innovation), a Spanish MEC grant (BFU2006-572), a JCYL-UE grant (GR221), an EU ERA net Neuron grant (EUI2009-04083), and a Spanish MICINN grant (BFU2009-07286). 


\section{ACKNOWLEDGMENTS}

First and foremost I would like to acknowledge the debt I owe to my supervisor, Dr. Manuel Malmierca, for the patient guidance, advice and inspiration he has provided me throughout all these years. His passion and enthusiasm for neuroscience is contagious and his intelligent pragmatism deserves my best admiration. I wish I could emulate these qualities throughout my career. 'Manolo, he aprendido contigo mucho más de lo que te puedas imaginar, te estoy infinitamente grata por todo.’

I must express my deepest gratitude to Ignacio Plaza, an outstanding technician who taught me almost everything I know about histology. 'Nacho, ha sido un lujo para mí poder recibir tu sabiduría y amistad a lo largo de estos años: és excepcional, bem hajas!'

I am deeply indebted to Dr. Israel Nelken (Hebrew Univ., Israel) who has contributed in a fundamental way to improving my work with his suggestions, creative ideas and invaluable help. I am also in great debt to Dr. Ellen Covey (Univ. Seattle, USA) for her enormous help and support in the first part of my thesis.

I am particularly grateful to many people who contributed with thoughtful and valuable comments on my work over these years: Dr. Adrian Rees (Univ. Newcastle, UK); Dr. Alan Palmer (Univ. Nottingham, UK); Dr. Daniel Llano (Univ. Chicago, USA); Dr. Carles Escera (Univ. Barcelona, Spain); Dr. Bernhard Gaese (Goethe Univ., Germany); and Dr. Xiaoqin Wang (Johns Hopkins Univ., USA).

I am sincerely thankful to Dr. Minna Huotilainen (Univ. Helsinki, Finland), and Dr. Piia Astikainen (Univ. Jyväskylä, Finland), for receiving me so nicely in their labs as a visiting student, during my stay in Finland. I am also grateful to all the people in these labs that made my stay there a great and fruitful experience.

I have learned much from Dr. Olga Hernández, who extremely kindly received me when I arrived to the lab 4 years ago; and from Dr. Anchieta, a resourceful scientist who was always ready and willing to help me with a friendly smile and word. I gratefully acknowledge both of them for everything. 
I would also like to extend my gratitude to all my colleagues from the auditory neuroscience group at the INCyL, specially to: Salvatore, for helping me to isolate the first neurons of my thesis; Jorge Martín and Dr. Enrique Lopez-Poveda, for help with some figures and statistical analysis; Dr. David Pérez-González, for preparing the macro that I used for some analysis; and Dr. Miguel Merchán, Dr. Enrique Saldaña and Dr. Dolores López for many helpful suggestions.

To all my colleagues and friends, whose names I cannot continue listing and who have assisted me in one way or another, especially in challenging me with alternative views, I feel very much indebted.

I would like to finish with a special thank to two colleagues/friends that accompanied me over the last year in the lab: 'Dan y Yan, it is simply a privilege to work and share a laugh with special people like you'.

I could not have accomplished this project and all projects in my life without the constant support and inspiration from my family: 'Mãe, pai e mano, sois os melhores do mundo!' 


\section{ORIGINAL PUBLICATIONS}

This thesis is based on the following publications:

Peer reviewed published article:

1. Antunes FM, Nelken I, Covey E and Malmierca MS (2010). Stimulus-specific adaptation in the auditory thalamus of the anesthetized rat. PloS ONE 5(11): e14071.

Proceeding article:

1. Antunes FM, Covey E and Malmierca MS (2009). Is there stimulus-specific adaptation in the auditory thalamus? In "Advances in Auditory Physiology, Psychophysics and Models", edited by EA Lopez-Poveda, AR Palmer and R Meddis (Springer, New York).

Article in preparation:

1. Antunes FM and Malmierca MS (2011). Top-down modulation of stimulus-specific adaptation in the medial geniculate body of the rat. In prep. 


\section{ABBREVIATIONS}

AC Auditory cortex

A1 Primary auditory cortex

CSI Common stimulus-specific index

FRA Frequency response area

IC Inferior colliculus

MGB Medial geniculate body

MGD Dorsal subdivision of the medial geniculate body

MGM Medial subdivision of the medial geniculate body

MGV Ventral subdivision of the medial geniculate body

MMN Mismatch negativity

PSTH Peristimulus time histogram

SI Frequency-specific index

SSA Stimulus-specific adaptation

TRN Thalamic reticular nucleus 


\section{TABLE OF CONTENTS}

$\begin{array}{ll}\text { INTRODUCTION } & 3\end{array}$

The auditory system and hearing $\quad 5$

The corticofugal pathway 14

The corticothalamic projections 15

Deviance detection in the auditory system 17

Stimulus-specific adaptation (SSA) 18

SSA in the auditory thalamus $\quad 19$

SSA and sensory memory $\quad 21$

SSA beyond the auditory system $\quad 22$

MATERIALS AND METHODS 25

$\begin{array}{ll}\text { Animals and anesthesia } & 27\end{array}$

$\begin{array}{ll}\text { Surgical procedures } & 27\end{array}$

Acoustic stimuli $\quad 28$

Electrophysiological recordings

Stimulus presentation paradigms

Location of neurons and histological verification of recording sites

Reversible cooling AC deactivation

Data analysis $\quad 36$

RESULTS 39

PART I: STIMULUS-SPECIFIC ADAPTATION IN THE MEDIAL GENICULATE BODY OF THE ANESTHETIZED RAT $\quad 42$

The common SSA index (CSI) to quantify SSA

Responses of the population of MGB neurons across stimulation conditions 44

General characterization of SSA across the MGB population 48

Characterization of SSA across MGB subdivisions $\quad 51$

Characterization of SSA within MGB subdivisions $\quad 54$

Temporal dynamics of SSA in the MGB 58

SSA in relation to discharge patterns and latencies

PART II: CORTICUFUGAL MODULATION OF STIMULUS-SPECIFIC ADAPTATION IN THE

MEDIAL GENICULATE BODY

Effect of AC deactivation on SSA in the MGB 66

Effect of AC deactivation on the temporal dynamics of SSA 69

Effect of $A C$ deactivation on the firing rate of $M G B$ neurons 72

Effect of AC deactivation on the latency of MGB neurons 76

$\begin{array}{lr}\text { DISCUSSION } & \mathbf{8 1}\end{array}$

SSA in the MGB: comparison with previous studies $\quad 84$

Hyperacuity to frequency differences in the MGB 88

May SSA be generated in a bottom-up fashion? 89

Gain control mechanism on the MGB responses but not on SSA by the AC 90

Technical considerations on the deactivation experiments 93

Multiple time-scales of SSA and sensory memory 94

Synaptic depression as a possible mechanism underlying SSA 96

Final remarks 97

CONCLUSIONS $\quad 99$

$\begin{array}{lr}\text { SUMMARY IN SPANISH } & 103\end{array}$

CONCLUSIONS IN SPANISH 133

$\begin{array}{ll}\text { CONCLUSIONS IN PORTUGUESE } & 137\end{array}$

$\begin{array}{lr}\text { REFERENCE LIST } & 141\end{array}$

$\begin{array}{lr}\text { ORIGINAL PUBLICATIONS } & 157\end{array}$ 
INTRODUCTION 
Life and death depends critically on one's ability to detect acoustic relevant signals, such as the call of a predator in the deafening jungle or a sound that pops out when we cross a noisy street. Rare sounds in the environment may therefore indicate events of behavioural importance to which an individual should attend for survival. How single neurons throughout the auditory system behave to participate in this task represents a challenging as much as attracting research topic in today's neuroscience.

The detection of rare sounds in the environment and its bio-ecological relevance is one of many reasons why audition is a fascinating and especially important aspect of sensation, and more generally of brain function. In humans, loss of hearing can be socially more debilitating than blindness, even though we are highly visual creatures. Hence, it is not surprising that the auditory system has evolved to be one of the engineering masterpieces of the human body (Purves et al., 2001)

\section{The auditory system and hearing}

The biological importance of the auditory system of vertebrates lies in its ability to provide animals with information about what the sounds mean and where sounds arise. In many animals, sounds also serve as a basis for communication. The task of extracting useful information from the representation of the physical characteristics of sound, its meaning and the location of its source, is a complex one to which animals have devoted a significant proportion of their brains (Oertel, 2002).

The ear transduces the mechanical energy in sound into electrical signals that provide the brain with the ongoing representation of the physical characteristics of sounds arriving at the two ears (Fig. 1; Oertel, 2002). At the basis of the system is an array of miniature acoustical detectors, packed into a space that in humans is no larger 
than a pea: the cochlea (Fig. 1). These cells, the hair cells, can faithfully transduce vibrations as small as the diameter of an atom, and they can respond a thousand times faster than visual photoreceptors (Fuchs et al., 2010). The cochlea originates a fundamental organization principle of the auditory system: the tonotopy, which depends on individual neurons being sensitive to different frequency ranges (von Bèkèsy, 1960).

a

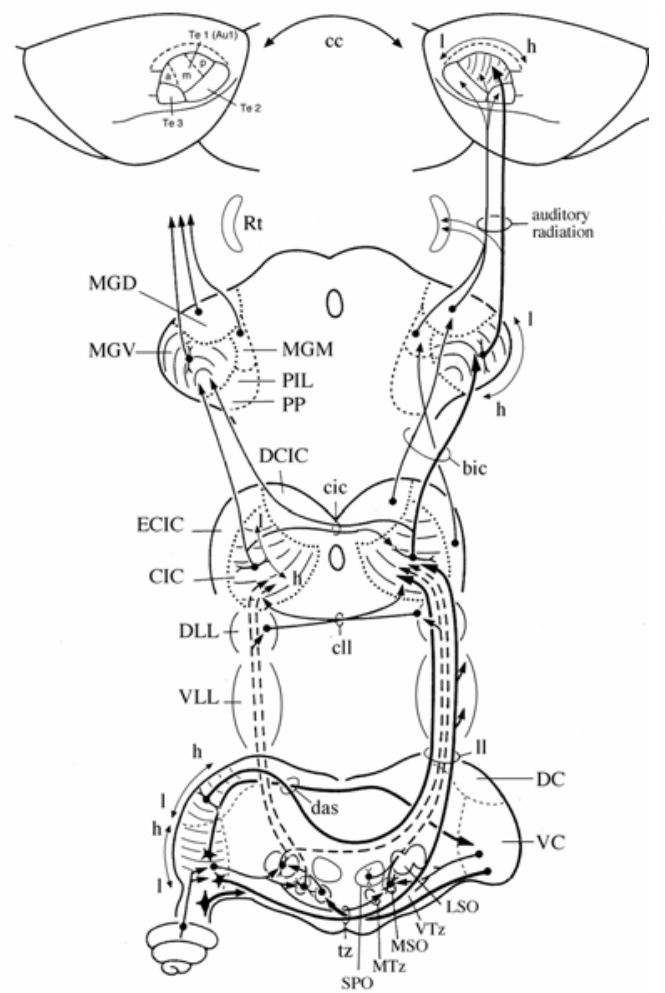

b

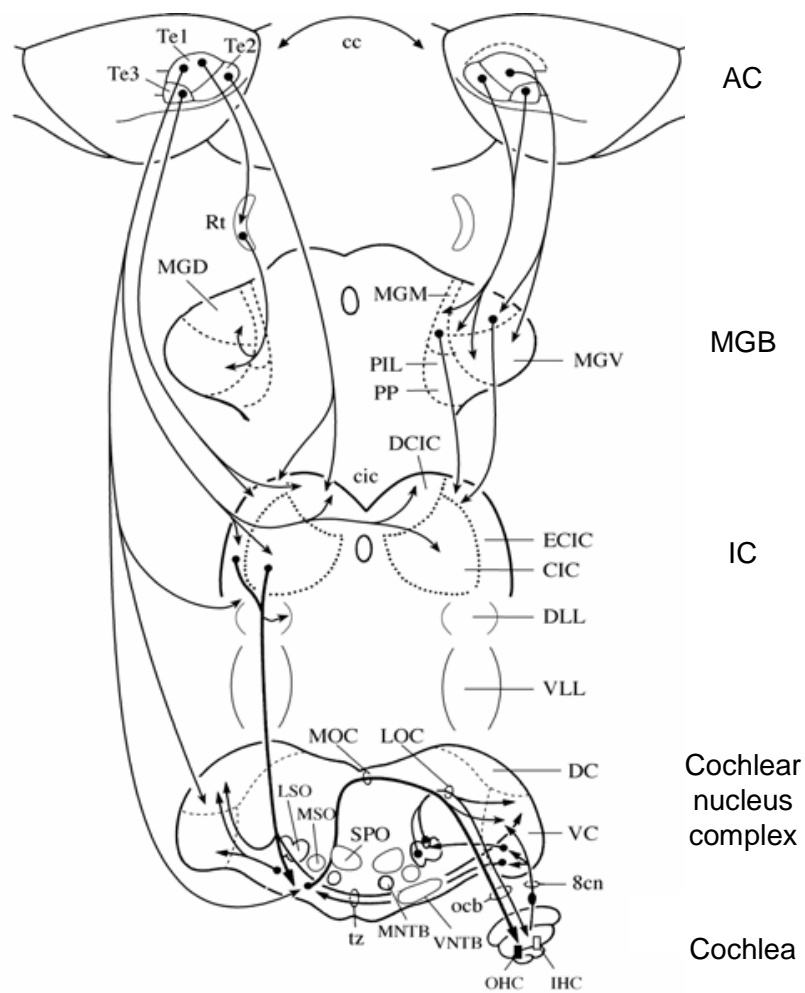

Figure 1. The auditory pathway: ascending (a) and descending projections (b) (From Malmierca, 2003; with permission of the author).

Projections from the cochlea travel via the eighth nerve to the divisions of the cochlear nucleus, from where a series of parallel channels emerge (Fig. 1). These projections include the superior olivary complex and nuclei of the lateral lemniscus (for review see Malmierca, 2003; Malmierca and Hackett, 2010), and the inferior colliculus (IC). The IC, on the auditory midbrain, is the target of all auditory pathways originating in the lower brainstem, and it is the principal source of input to the auditory thalamus 
(medial geniculate body, MGB). From the IC and upwards, the auditory pathway can be divided into a 'lemniscal projection' where the tonotopic organization is clear and a 'non-lemniscal projection' where it is less clear (Malmierca, 2003).

Projections from the IC reach the MGB, a nucleus that lies on the posterolateral surface of the thalamus as a rounded eminence (Figs. 1-3). It represents the main auditory centre of the thalamus and is the last centre for auditory processing before inputs reach the auditory cortex (AC; Fig. 1). Although the MGB plays a central role in auditory processing, it has received less attention than other subcortical structures. Traditionally, the MGB has been considered as a simple relay station for sensory information reaching the AC. Nevertheless, growing evidence from auditory and other sensory systems suggest that the MGB and the other thalamic nucleus actively regulate the flow of sensory information and modulate sensory signals (Alitto and Usrey, 2003; Sherman and Guillery, 1998; Sherman, 2007). This modulation in the MGB is enabled by dynamic interactions between ascending inputs from brain stem nuclei, and corticofugal projections (Scannell et al., 1999) that act as 'drivers' and 'modulators' (Sherman and Guillery, 1998).

The MGB has three main subdivisions: ventral (MGV), dorsal (MGD) and medial (MGM), defined on the basis of cytoarchitectonic and functional studies (Bordi and LeDoux, 1994a; Bordi and LeDoux, 1994b; Morest, 1964; Morest, 1965b; Morest, 1965a; Winer and Morest, 1983; Winer and Morest, 1984; Figs. 2 and 3). The MGV contains large (principal), bi-tufted, thalamocortical 'relay' neurons that typically receive input from the ipsilateral tonotopically-organized central nucleus of the IC and respond transiently, sensitively, and discretely to pure tone stimulation of the contralateral ear (Winer et al., 2005; Fig. 3). MGV bi-tufted cells have specialized and highly oriented dendritic arbors arranged in parallel with the afferent fibres, resulting in 
a laminar organization, i.e. the fibrodendritic laminae (Cetas et al., 2003; Winer et al., 1999; Fig 3). McMullen and colleagues (2005) propose a model in which the cellular laminae, the oriented dendritic arbors and the tectothalamic axons are the basis for the tonotopic map at this level of the auditory system, for the rabbit, which is similar to that described in rat (Winer et al., 1999). Despite their close synaptic relationship and similar tonotopic representation, the MGV and the central nucleus of the IC possess quite different functional architectures (Cetas et al., 2003; McMullen et al., 2005).

a

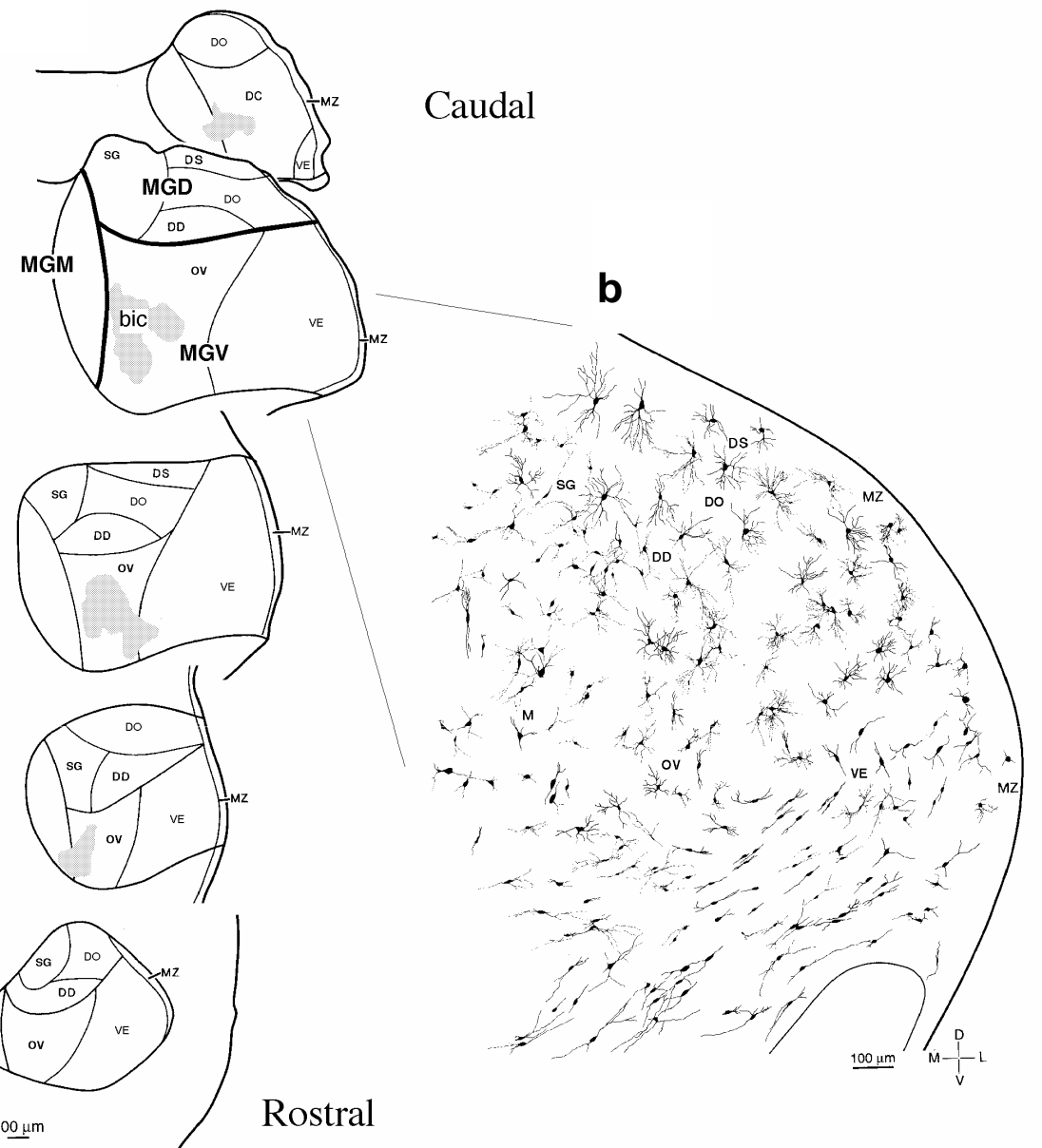

Figure 2. The medial geniculate body (MGB) of the rat. (a) Schematic caudal-rostral representations of the MGB in the transverse plane. (b) Neuronal types in the different MGB subdivisions (From Winer et al., 1999). 


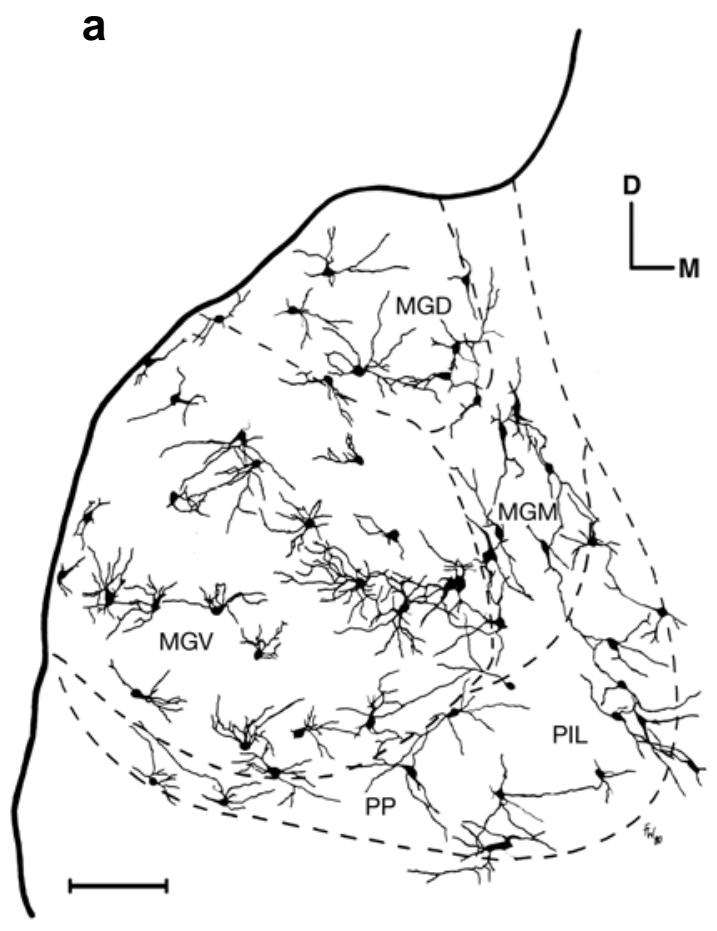

b

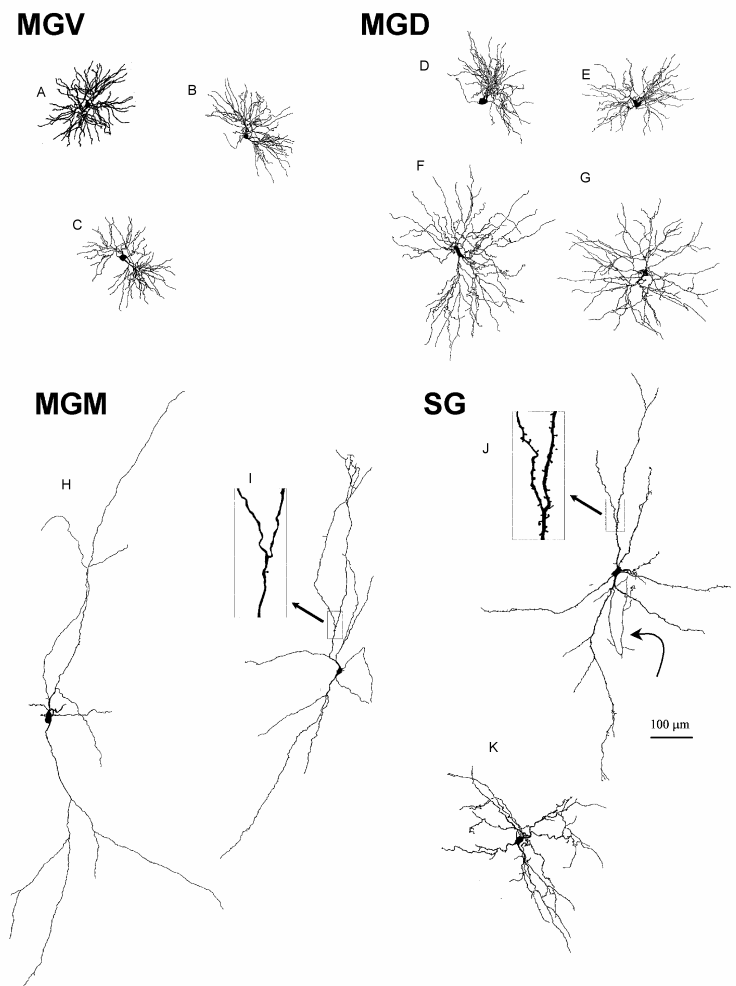

Figure 3. Neurons in the ventral (MGV), dorsal (MGD) and the medial (MGM) subdivisions of the MGB (in the present work I included the suprageniculate (SG) within the MGD subdivision; (a) adapted from Ryugo and Weinberger, 1976; (b) Bartlett and Smith, 1999).

The MGD contains two types of neurons: tufted neurons with a similar structure, although not identical, to those of the MGV; and stellate neurons with radiate dendrites (Bartlett and Smith, 1999; Clerici and Coleman, 1990; Winer et al., 1999; Fig. 3). Neither the cell bodies nor the dendrites appear to be oriented in any particular fashion and the MGD is not tonotopically organized. The biophysical properties of the MGD neurons resemble those of the MGV (Fig. 3). Both cell types of the MGD receive excitatory and inhibitory inputs from the IC, excitatory inputs from the cortex and inhibitory inputs from the thalamic reticular nucleus (TRN; Fig. 4). The MGM extends the full length of the MGB as a flat lentiform nucleus about $200 \mu \mathrm{m}$ wide and contains a diverse population of neurons, the most usual ones being the magnocellular neurons (Figs. 2 and 3). The MGM cells have large stomata and low packing density, and have 
broad auditory tuning (Ojima and Rouiller, 2011; Fig. 3). The MGM has a tonotopic map in its anterior sector that is less ordered than in MGV (Aitkin, 1973). Neurons in the MGM and MGD typically respond less well to pure-tones than to more complex stimuli. The MGM receives projections from the external cortex of the IC; and the MGD receives projections from the external and dorsal cortices of the IC (Malmierca, 2003). Both subdivisions have been implicated in multisensory interactions, processing of communication signals, auditory learning and emotional significance of auditory stimuli (Kimura et al., 2007; Komura et al., 2001; Komura et al., 2005; Winer et al., 2005).

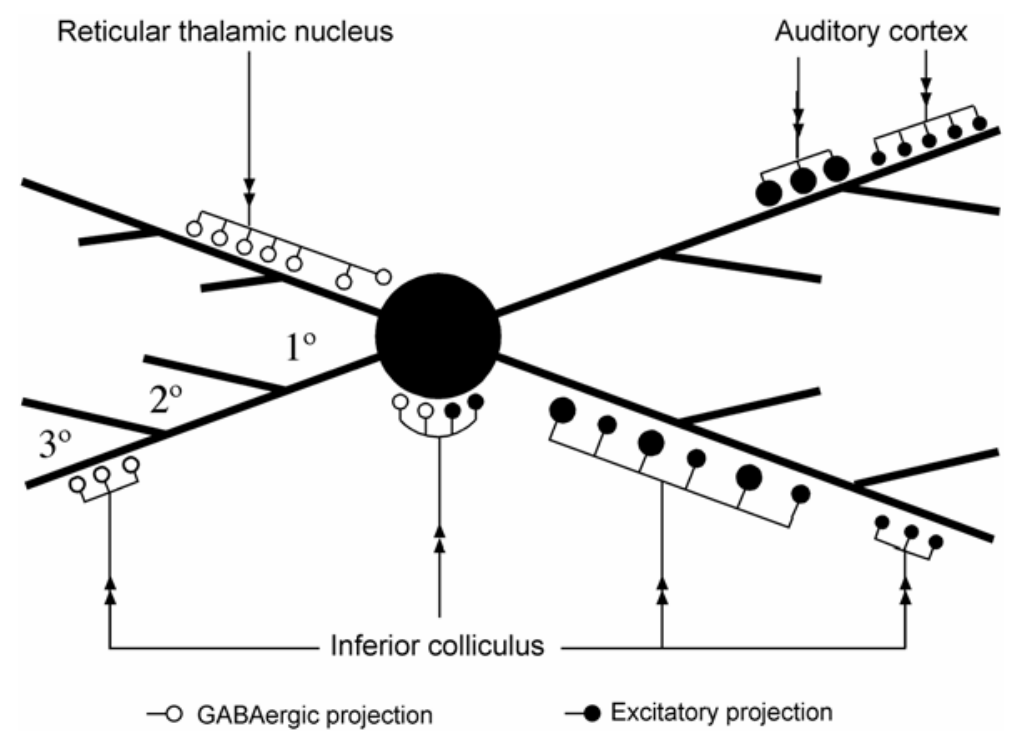

Figure 4. The inputs of a thalamic neuron. Excitatory inputs from the auditory cortex and inferior colliculus; and inhibitory (GABAergic) inputs from the reticular thalamic nucleus and inferior colliculus (schematic representation from Malmierca, 2003; with permission of the author).

The MGD mainly projects to two non-primary discrete regions of the AC in rat: the dorsal fringe of caudal primary auditory area, designated as posterodorsal area, and the ventral margin of rostral primary auditory area, designated as ventral area (Donishi et al., 2006; Kimura et al., 2007). Both areas relay information from the MGD to higher 
cortical information processing, and are thought to serve important non-lemniscal functions in tandem for cortical and subcortical processing (Donishi et al., 2006; Kimura et al., 2007). The posterodorsal area sends a prominent projection to the posterior parietal cortex and is assumed to play a pivotal role in auditory spatial processing for directed attention (Kimura et al., 2004; Kimura et al., 2007). As the counterpart of posterodorsal area, the ventral area is assumed to give rise to another major stream of cortical information processing, most probably related to emotion (Kimura et al., 2007; Kimura et al., 2010). The ventral area relays input from the MGD to the insular cortex, which, receiving cortical and thalamic somatosensory inputs (Zhang and Giesler, Jr., 2005), has been considered pivotal for affective memory formation (Kimura et al., 2007). It has also been implicated in several aspects of auditory processing such as attention to novel sounds, and temporal and phonological recognition (Augustine, 1996; Bamiou et al., 2003).

The MGM receives convergent inputs from auditory, somatosensory and visual structures and can respond to one or more of these multiple modalities (Smith and Spirou, 2002). It is well known that MGM is the main direct input to the amygdala. Early reports indicated that the MGM is unique in its ability to show physiological plasticity or long-term potentiation during classical conditioning paradigms that pair a somatosensory with and auditory stimulus (Gerren and Weinberger, 1983; Ryugo and Weinberger, 1978). Since then, the MGM has been implicated in the learning-induced expression of the conditioned fear response to auditory stimuli, via the amygdala (LeDoux, 1995; LeDoux and Muller, 1997), and the expression of long term plasticity in the AC as well (Weinberger et al., 1995; Weinberger and Bakin, 1998). A recent study by Antunes and Moita (2010) suggested that the MGM-amygdala direct pathway is important to suppress fear of neutral or safe auditory stimuli, thereby affecting the 
acquisition and recall of discriminative fear (involving the suppression of fear to a tone that is not followed by shock) as well as the extinction of fear of an auditory cue that was previously paired with shock.

The AC is part of the temporal cortex (for a review see Malmierca, 2003) and represents the site of termination of fibres ascending from the MGB (Figs. 1, 5 and 6). The AC shows large variations between species and has been mostly studied in the cat. In all mammals studied, a core koniocortex, with one or more complete and orderly representations of audible frequencies was found to be surrounded by belt areas with less sharp frequency representation (for review see De Ribaupierre, 1997; Kelly, 1990; Winer, 1992). In the rat, several cortical maps have been proposed (e.g., Doron et al., 2002; Malmierca and Hackett, 2010; Polley et al., 2007), however, the lack of gross anatomical landmarks makes the comparison of the various maps difficult. On the basis of the patterns of thalamocortical, corticothalamic and callosal input, as well as on physiological responses, the $\mathrm{AC}$ of rat can be divided into a primary auditory cortex (A1) and a surrounding belt region that includes the secondary auditory areas (reviewed in Kelly, 1990; Fig. 1).

Based on Nissl-stained and Golgi-impregnated material obtained, (Games and Winer, 1988) have analysed the neuronal architecture of A1 in rat (Figs. 5 and 6). They distinguished 6 layers, extending over about 1.1 to $1.2 \mathrm{~mm}$ (Figs. 5 and 6): layer I, with very few neurons and extending about $140 \mu \mathrm{m}$ from the pial surface; layer II, with many small neurons and densely packed (125 $\mu \mathrm{m}$ thick); layer III, populated by both pyramidal and non-pyramidal neurons, whose dendritic arbors are heterogeneous in orientation (190 $\mu \mathrm{m}$ thick); layer IV, in which the main cell type is the small stellate (100 $\mu \mathrm{m}$ thick); layer $\mathrm{V}$, with pyramidal cells and lower neuronal packing density than layer IV (270 $\mu \mathrm{m}$ thick); and finally, layer VI that contains both pyramidal (including 
inverted pyramidal neurons whose 'basal' dendritic arbor is directed towards the white matter) and non-pyramidal cell (bitufted and multipolar neurons) types that are closely packed (245 $\mu \mathrm{m}$ thick). Layers V and VI are of particular interest because their cells form part of the projection to the thalamus, subthalamic nuclei and also to the contralateral cortex (Feliciano and Potashner, 1995; Games and Winer, 1988; Hefti and Smith, 2000; Moriizumi and Hattori, 1991; Ojima, 1994; Saldana et al., 1996; Weedman and Ryugo, 1996a; Weedman and Ryugo, 1996b; Fig. 6)

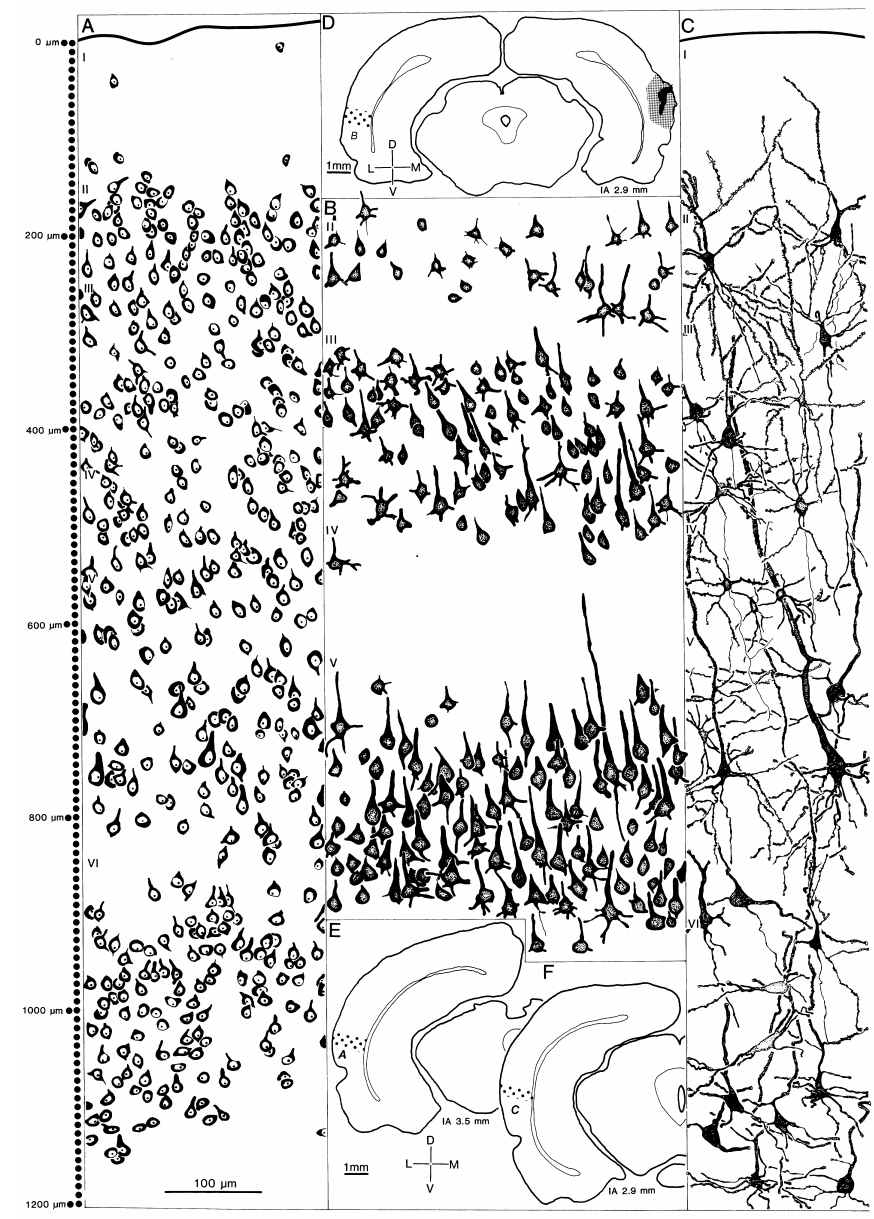

Figure 5. The cytoarchitecture of the auditory cortex of the rat (from Games and Winer, 1988). 


\section{The corticofugal pathway}

Recent anatomical and physiological studies have challenged the view of 'bottom-up' hierarchical processing in the auditory system, revealing massive descending pathways that stream from all regions of the $\mathrm{AC}$ to subcortical brain structures, by direct or indirect pathways (Winer and Lee, 2007; Figs.1 and 6b). These extensive corticofugal projections have been implicated in gain control, signal filtering and other dynamic functions (Liu et al., 2010; Luo et al., 2008; Robinson and McAlpine, 2009; Sun et al., 2007). It has been demonstrated that the corticofugal projections modulate lower brain centres, such as the cochlear nucleus (Liu et al., 2010; Luo et al., 2008), and presumably, can exert influences to the level of cochlear hair cells (Winer and Lee, 2007). In view of these findings, the corticofugal pathway was suggested to implement a selective processing taking place at the initial levels of sound processing as a way to reduce irrelevant sound information reaching the brain (Luo et al., 2008).

As understanding of the importance of 'top-down' processing in the brain expands, the MGB is receiving increasing attention because of its position at the crossroads of auditory processing. Although medullar and midbrain auditory centres form topographic maps and analyse acoustic parameters, survival requires that the auditory thalamus and cortex extract and transform information representing biologically and ecologically aspects of the sound that are essential for perceptual analysis and behaviour. Communicative, predatory, and reproductive behaviours rely on the thalamocortical system, a key nexus that combines, transforms and distributes virtually all acoustic information relevant to survival (Winer et al., 2005). 
a

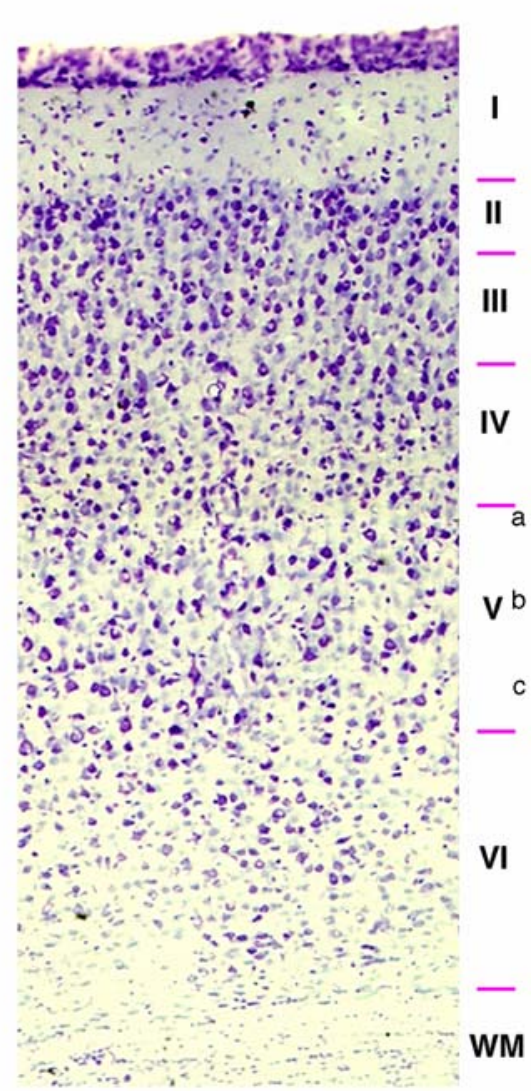

b

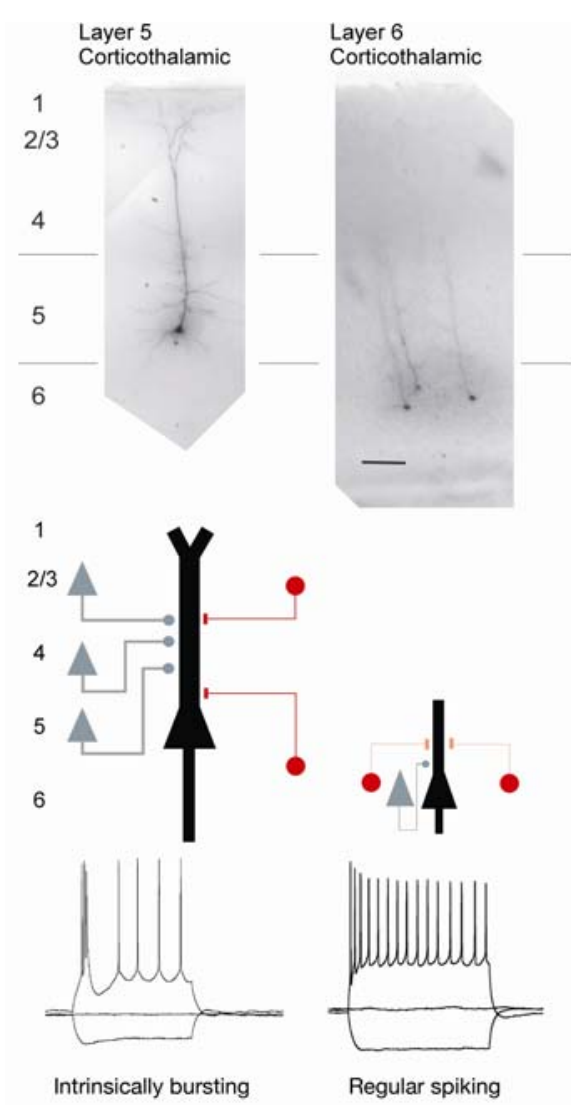

Figure 6. The layers of the primary auditory cortex (A1) in rat. (a) Nissl stained section showing the six layers of A1 (adapted from Doucet et al., 2003). (b) Neurons from layers V and VI of AI that project to the thalamus (adapted from Llano and Shermann , 2008).

\section{The corticothalamic projections}

The massive set of corticofugal projections the MGB receives is one of its most remarkable features. In rat, these projections outnumber the ascending projections by a factor of 10 (Kimura et al., 2004; Kimura et al., 2005; Kimura et al., 2007; Ojima and Rouiller, 2011; Winer, 2006; Winer and Lee, 2007). All three MGB subdivisions receive corticofugal projections, either terminating on MGB principal neurons, and/or on GABAergic projection neurons in the thalamic reticular nucleus (TRN), which project to the MGB and exerts a strong inhibitory effect on its non-lemniscal subdivisions (He, 2003a; He, 2003b; Villa, 1990; Yu et al., 2004; Figs. 1b and 4). 
Tonotopic AC areas target tonotopic MGB divisions preferentially, nontonotopic areas project largely to non-tonotopic thalamic nuclei. Polimodal associative MGB regions, such as the MGM, receive input from all $\mathrm{AC}$ areas and from nonauditory cortex (Winer et al., 2001; Winer et al., 2005). The corticothalamic projection mainly originates in layer VI pyramidal neurons from the $\mathrm{AC}$, whose terminals are small and modulatory in nature (Fig. 6 and 7). A numerically smaller corticothalamic projection arises from layer $\mathrm{V}$ neurons and produces large terminals that are able to drive post-synaptic responses (Bajo et al., 1993; Bartlett et al., 2000; Llano and Sherman, 2008; Ojima, 1994; Rouiller and Welker, 1991; Rouiller and Welker, 2000; Fig. 6 and 7).

Llano and Shermann (2008) propose a model of non-reciprocal organization of the mouse auditory thalamocortical-corticothalamic projection systems, in that there are two types of circuits: i) a reciprocal circuit originating in the MGV or MGD, projecting mainly to layers IV and VI of the lemniscal or non-lemniscal AC, respectively, and then projecting from layer VI of the thalamic region of origin via modulator terminals; and ii) a non-reciprocal circuit, originating in layer $\mathrm{V}$ of the lemniscal $\mathrm{AC}$, projecting to the MGD via driver terminals, and then projecting mainly to layers IV and VI of the nonlemniscal AC (Fig. 7).

It is well known that the corticofugal pathway strongly modulates the responses of MGB neurons, as demonstrated by several studies that used different techniques, such as cortical cooling or electrical stimulation (He, 2002; He, 2003a; Palmer et al., 2007; Ryugo and Weinberger, 1976; Villa et al., 1991; Villa et al., 1999). Hence, the cortical 'feedforward' to the thalamus has been suggested as a gain-control mechanism modulating the ascending transmission of sensory information en route to higher levels (He, 2003a; Suga and Ma, 2003; Villa et al., 1991). 


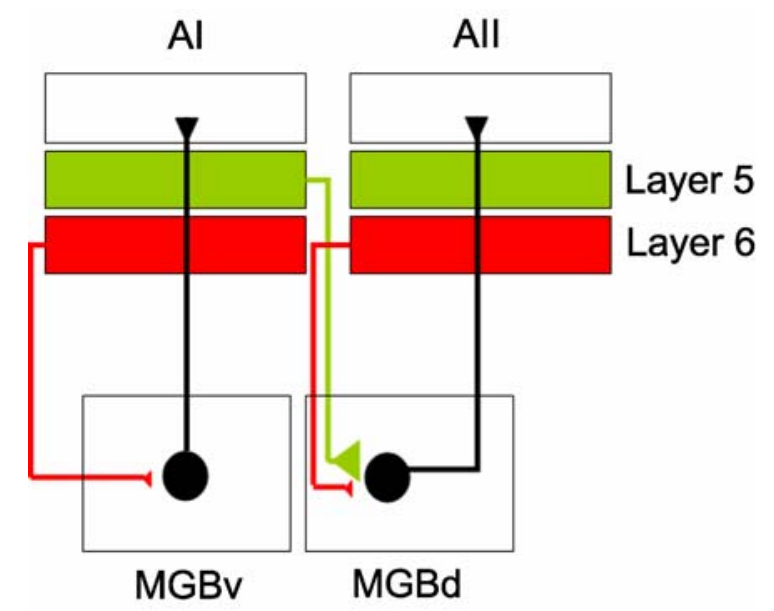

Figure 7. Diagram illustrating the cortico-thalamo-cortical model of cortical processing proposed by Llano and Shermann (2008).

\section{Deviance detection in the auditory system}

An important task of the auditory system is to alert the animals to the presence of danger. An animal must quickly detect new auditory events or objects in a dynamic and noisy acoustic environment for survival. The detection of such changes requires an online modulation of activity in the auditory system and represents one of the challenges the auditory system faces continuously. Given its importance, it is not surprising that the brain has evolved specific mechanism to distinguish new acoustic events embedded in a background of familiar or repetitive ones.

Indeed, deviance detection is a phenomenon well known to occur in the auditory cortex in humans (Escera et al., 1998; Escera et al., 2003; Näätänen, 1992; Tiitinen et al., 1994), monkeys (Javitt et al., 1994) and cats (Csepe et al., 1987b; Csepe et al., 1987a), as measured by the mismatch negativity event-related potential (MMN; Fig. 8). MMN is elicited by sounds violating some aspect in the regularity of the stimulus sequence, as deduced from the preceding stimulation (e.g., in frequency, amplitude, spatial location and frequencies sweep direction) and occurs even in the absence of 
attention (Csepe et al., 1987b; Csepe et al., 1987a; Kraus et al., 1994; Näätänen, 1992). MMN is measured in an oddball design, where rare sounds (deviants) are randomly embedded within sequences of common sounds (standards); it is defined as the difference between the event-related potentials for the deviants and the standards (Fig. 8). This phenomenon is sensitive to the stimulus history and its magnitude depends on the probability of the deviant stimuli. The enhanced responses to the deviants are usually interpreted as an indication that the brain effectively stores a 'memory trace' of the standard stimuli, to which the incoming stimuli are compared, leading to stronger responses elicited by the mismatching deviants (Naatanen et al., 2001; Naatanen et al., 2007; Näätänen, 1992).

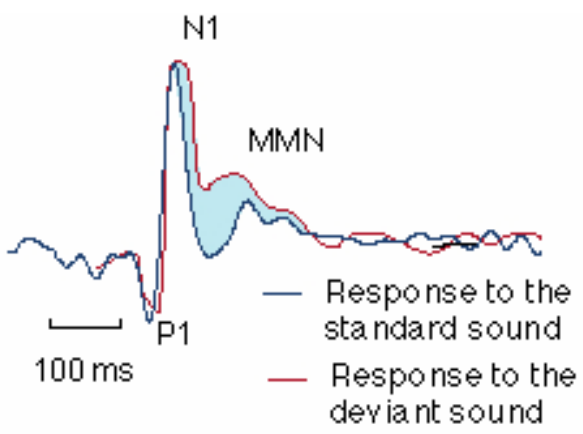

Figure 8. The response of the human brain to standard and deviant sounds, as measured by event-related potentials. The mismatch negativity is defined as the difference between the eventrelated potentials for the deviants and the standards (MMN, blue).

\section{Stimulus-specific adaptation (SSA)}

At the single neuron level, the detection of rare acoustic events is reflected by stimulusspecific adaptation (SSA), whereby neurons adapt to frequently occurring stimuli, but resume firing when 'surprised' by rare or new ones. When sounds are presented using an oddball paradigm similar to that used to evoke mismatch negativity (MMN; Escera et 
al., 1998; Escera et al., 2003; Näätänen, 1992; Fig. 9), neurons in the auditory cortex (AC; Szymanski et al., 2009; Ulanovsky et al., 2003; Ulanovsky et al., 2004; von der Behrens et al., 2009) and inferior colliculus (IC; Malmierca et al., 2009; Perez-Gonzalez et al., 2005; Reches and Gutfreund, 2008; Zhao et al., 2011) adapt in a stimulus-specific manner. This form of adaptation is rapid and highly sensitive to stimulus statistics: it depends on the relative probabilities of the standard and deviant stimuli, on the contrast between both frequencies, and on presentation rate (Lumani and Zhang, 2010; Malmierca et al., 2009; Reches and Gutfreund, 2008; Ulanovsky et al., 2003; Ulanovsky et al., 2004; Zhao et al., 2011). In the AC, SSA has been demonstrated to show high frequency sensitivity (hyperacuity) and to occur mainly in the sustained part of the neuronal response (Ulanovsky et al., 2003). For this reason, Ulanovsky and colleagues (2003) proposed that intra-cortical processing contributed to SSA in A1, leading to the observed long latency of SSA. On the other hand, neurons exhibiting SSA in the IC tend to be mainly onset responders with short latencies (Malmierca et al., 2009; Zhao et al., 2011). These results suggest that, as opposed to SSA in A1 neurons that seems to be modulated and/or enhanced by intracortical mechanisms, neurons in the midbrain may participate in a bottom-up generation of SSA (Malmierca et al., 2009).

\section{SSA in the auditory thalamus}

SSA is known to be present in the thalamus: Yu and colleagues (2009) demonstrated strong SSA in the reticular nucleus. However, the contribution of the medial geniculate body (MGB) and its main subdivisions to SSA and detection of rare sounds remains poorly characterized. Ulanovsky and colleagues (2003) found very low levels of SSA in the MGB of the cat, presumably in the ventral subdivision, but no details were given, 
for the same parameter range that elicited strong SSA in A1. The values found in the MGB in Ulanovsky and colleagues' study were similar to those found in the IC central nucleus of rat by Malmierca and colleagues (2009), but very low comparatively to those observed in the non-lemniscal IC subdivisions by these authors. A recent report of SSA in the MGB of mice (Anderson et al., 2009) showed substantially weaker levels of adaptation than those found in AC (Ulanovsky et al., 2003; von der Behrens et al., 2009) or IC (Lumani and Zhang, 2010; Malmierca et al., 2009; Zhao et al., 2011), in both lemniscal and non-lemniscal MGB subdivisions.

Given its connections with the AC and the IC (Fig. 1), one would expect neurons in the MGB to show strong SSA as well. In particular, the differences in the SSA exhibited by neurons in the three main subdivisions of the MGB need to be clarified. The mouse MGB study showed SSA in the MGM and in the lemniscal MGV but not in the non-lemniscal MGD subdivision. Nevertheless, the studies of the rat IC (Malmierca et al., 2009; Perez-Gonzalez et al., 2005) demonstrated stronger SSA in the nonlemniscal regions than in the lemniscal central nucleus. This is in accordance with earlier studies that showed that adaptation in non-primary auditory cortices (Schreiner and Cynader, 1984) and in association cortices (Irvine and Huebner, 1979) is stronger than in A1.

Even though SSA is strong in the non-lemniscal subcortical regions (Malmierca et al., 2009; Perez-Gonzalez et al., 2005), AI is the first lemniscal station where it is widespread and strong (Ulanovsky et al., 2003). Thus, SSA may emerge in the AC (Ulanovsky et al., 2003; Ulanovsky et al., 2004), as a high order feature of sensory processing that can be inherited by subcortical nuclei via the corticofugal pathway (Nelken and Ulanovsky, 2007). However, this hypothesis remains so far unexplored. 


\section{SSA and sensory memory}

One of the most interesting characteristics of SSA resides in its dependence on the history of the stimulation rather than on the activity of the neuron (Reches et al., 2010; Ulanovsky et al., 2004; Zhao et al., 2011). In this way, SSA differs from other forms of adaptation that depend mostly on the previous activity of the neuron, such as 'fatigue' (e.g., Carandini, 2000; Sanchez-Vives et al., 2000a; Sanchez-Vives et al., 2000b) or 'exhaustion' (Avissar et al., 2007).

Neurons showing SSA integrate sensory information to create a predictive model of the stimulation and detect deviant features in the environment. SSA may therefore function as a kind of novelty detection, adjusting the strength of the response of a neuron based on the information that it receives (Wark et al., 2007). Such a neuron would continuously compare current input with past stimulation conditions through network computations (Abbott et al., 1997; Eytan et al., 2003).

An intriguing possibility is that SSA leaves a short term memory trace that guides the response of the neuron to subsequent stimulation (Jaaskelainen et al., 2007; Nelken et al., 2003; Nelken and Ulanovsky, 2007; Reches and Gutfreund, 2008). This suggests SSA as a candidate neuronal mechanism for auditory sensory memory as reported in MMN studies (Haenschel et al., 2005; Jaaskelainen et al., 2007; Nelken and Ulanovsky, 2007). Ulanovsky and colleagues (2004) reported that the auditory memory trace ranges from milliseconds to tens and possibly hundreds of seconds in A1 neurons, leading to multiple timescales of adaptation. These timescales are similar to the duration of sensory memory reported in MMN studies (Bottcher-Gandor and Ullsperger, 1992). A recent study in humans (Haenschel et al., 2005) demonstrated that the MMN memory trace effect was related to a repetition positivity wave, with 50 to $250 \mathrm{~ms}$ latency, in the standard event-related potential. These authors suggest that the repetition positivity 
component is a human event-related potential correlate of rapid SSA in AC neurons (Haenschel et al., 2005).

Several functional roles have been attributed to adaptation in general, and specially to those forms of adaptation that like SSA create a dependence on the history of the stimulation, such as: gain control and neural coding optimization (Dean et al., 2008; Schwartz and Simoncelli, 2001; Wark et al., 2007; Wark et al., 2009); maximization of information transmission (Brenner et al., 2000; Fairhall et al., 2001; Smirnakis et al., 1997); increment in the discriminability of the incoming stimuli (Malone and Semple, 2001; Malone et al., 2002; Muller et al., 1999); and economization of spikes (deCharms and Merzenich, 1996). In the auditory brain, SSA has been linked to auditory memory, recognition of acoustic objects and scene analysis (Nelken, 2004; Winkler et al., 2009).

\section{SSA beyond the auditory system}

SSA is not an exclusive phenomenon of the auditory system. Similar types of adaptation occur in the visual and somatosensory systems (auditory: Anderson et al., 2009; Baeuerle et al., 2009; Malmierca et al., 2009; Perez-Gonzalez et al., 2005; Reches and Gutfreund, 2008; Reches et al., 2010; von der Behrens et al., 2009; Yu et al., 2009; Zhao et al., 2011; visual: Dragoi et al., 2000; somatosensory: Katz et al., 2006), suggesting that sensory adaptation is often stimulus-specific over different sensory modalities. Beyond sensory neuroscience, SSA has been demonstrated in networks of cortical neurons developing ex-vivo (Eytan et al., 2003), indicating the importance of this property as a basic brain mechanism. Moreover, SSA may be a component of short- 
term memory in neuronal networks since it creates a non-trivial dependence of neuronal responses on the history of the stimulation (Ulanovsky et al., 2004). 
MATERIALS AND METHODS 


\section{Animals and anesthesia}

In my $\mathrm{PhD}$ research I performed the experiments on 51 female adult pigmented rats (Rattus norvegicus, Rj: Long-Evans) with body weights between 150-250 g. Of the 51 animals, I used 34 to record neurons throughout the MGB aiming to characterize SSA in this nucleus (Results section, Part I). Subsequently, I used 17 animals to address if the $\mathrm{AC}$ conveys SSA to the MGB, using the cooling technique to deactivate the $\mathrm{AC}$, while recording neurons throughout the MGB (Results section, Part II).

I carried out all the experiments at the University of Salamanca with the approval of, and using methods conforming to the standards of, the University of Salamanca Animal Care Committee. I induced and maintained surgical anaesthesia of the animals with urethane $(1.5 \mathrm{~g} / \mathrm{Kg}, 20 \%$ solution i.p.; Sigma-Aldrich Inc., St Louis, MO, USA), and gave supplementary doses (0.5 g/Kg, i.p.) as needed. I selected urethane as the anaesthetic because its effects on multiple aspects of neural activity, including inhibition and spontaneous firing, are known to be less than those of barbiturates and other anaesthetic drugs (Hara and Harris, 2002).

\section{Surgical procedures}

At the beginning of the surgical procedures, I cannulated the trachea of the animals and administered atropine sulphate $(0.05 \mathrm{mg} / \mathrm{kg}$, s.c. $)$ subcutaneously to reduce bronchial secretions. I used a thermostatically controlled blanket to monitor and maintain the body temperature of the animals at $38^{\circ} \mathrm{C} \pm 1^{\circ} \mathrm{C}$. I placed the animals in a stereotaxic frame in which the ear bars were replaced by hollow perspex speculi that accommodated a sound delivery system. Then, I performed a craniotomy to expose the cerebral cortex overlying the MGB on one side (in all animals, both set of experiments) and furthermore the 
auditory cortex on the same side in the cooling experiments (17 animals). I removed the dura overlying the cerebral cortex to allow the electrode to reach the MGB for extracellular recordings, in all experiments. In selected cooling experiments (3 out of 17) I removed also the dura overlying the $\mathrm{AC}$, to record in the $\mathrm{AC}$ in order to confirm its deactivation during cooling.

\section{Acoustic stimuli}

The animals were situated inside a double-walled sound attenuation room and stimuli were delivered through a closed acoustic system based on two electrostatic loudspeakers (TDT- EC1) housed in an alloy enclosure and coupled to damped probe tubes $(3 \mathrm{~mm}$ diameter) which fitted into perspex specula. The loudspeakers were driven by two TDTED1 modules.

I used pure tone bursts that were delivered to the ear contralateral to the MGB where the recordings were performed in all animals. The pure tone bursts were delivered under computer control using TDT System 2 (Tucker-Davis Technologies) hardware and custom software (Faure et al., 2003; Malmierca et al., 2009; PerezGonzalez et al., 2006). I calibrated the output of the system at each ear in situ using a 1/4,' condenser microphone (Brüel and Kjær 4136, Nærum, Denmark) and a DI-2200 spectrum analyser (Diagnostic Instruments Ltd., Livingston, Scotland, UK). The maximum output of the TDT system was flat from $0.3-5 \mathrm{kHz}(\sim 100 \pm 7 \mathrm{~dB}$ SPL $)$ and from $5-40 \mathrm{kHz}(90 \pm 5 \mathrm{~dB}$ SPL). The highest frequency produced by this system was limited to $40 \mathrm{kHz}$. The second and third harmonic components in the signal were $40 \mathrm{~dB}$ or more below the level of the fundamental at the highest output level (Hernandez et al., 2005; Malmierca et al., 2008). 


\section{Electrophysiological recordings}

To record the extracellular single unit responses in the MGB I used tungsten electrodes (1-2 M ; Merryll and Ainswoth, 1972) that I lowered through the cortex to reach the MGB. I advanced the electrode using a Burleigh microdrive. To record the action potentials of neurons in the MGB I used a BIOAMP amplifier (TDT), the 10x output of which was further amplified and bandpass-filtered (TDT PC1; $\mathrm{f}_{\mathrm{c}}, 500 \mathrm{~Hz}$ and $3 \mathrm{kHz}$ ) before passing through a spike discriminator (TDT SD1). Spike times were logged on a computer by feeding the output of the spike discriminator into an event timer (TDT ET1) synchronized to a timing generator (TDT TG6). I used custom software to control stimulus generation and on-line data visualization. Spike times were displayed as dot rasters ordered by the acoustic parameter varied during testing. I used pure tones or noise bursts as search stimuli.

I determined audiovisually the approximate frequency tuning of the neurons, to the extent possible. To obtain the minimum threshold and best frequency of the neurons I used an automated procedure with 2-5 stimulus repetitions at each frequency step and intensity level. Next, I used a randomized stimulus presentation paradigm (frequency steps and intensity levels) to obtain automatically the monaural frequency response area (FRA, i.e., the combination of frequencies and intensities capable of evoking a response; e.g., Fig. 9), which I plotted using MATLAB. The stimuli that I used to generate FRAs in single units were pure tones with $75 \mathrm{~ms}$ duration and a $5 \mathrm{~ms}$ rise/fall time. I varied the frequency and intensity of the stimulus randomly $(0-100 \mathrm{~dB}$ attenuation in 5 or $10 \mathrm{~dB}$ steps and in 25 frequency steps from $0.5-40 \mathrm{kHz}$ to cover approximately 2-3 octaves above and below the best frequency; Hernandez et al., 2005; Malmierca et al., 2008). 


\section{Stimulus presentation paradigms}

In all experiments, I presented the stimuli in an oddball paradigm similar to that used to record mismatch negativity responses in human studies (Näätänen, 1992), and more recently in the cat auditory cortex (Ulanovsky et al., 2003; Ulanovsky et al., 2004) and rat inferior colliculus (Malmierca et al., 2009). Stimuli consisted of two different pure tones (f1 and $\mathrm{f} 2$ ), at a level of 10-40 dB above threshold, selected from within the FRA of each neuron (Fig. 9). The oddball paradigm consisted of a train of 400 stimuli containing both frequencies in a pseudo-random order, at a specific repetition rate, varying the probability of each frequency: f1 was presented with high probability (standard frequency; $90 \%$ or $70 \%$ probability) and f 2 had low probability (deviant; $10 \%$ or $30 \%$ ) within the sequence (Fig. 9). After obtaining one data set, I presented a second train of 400 stimuli, in which the probabilities of the two frequencies were reversed (f2 as standard; f1 as deviant; Fig. 9).

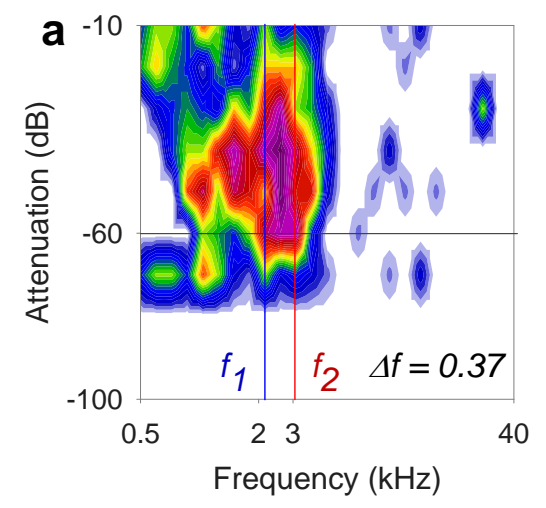

b

Figure 9. The oddball paradigm. (a) Example of the frequency response area (FRA) of a neuron from where I selected the frequencies ( $\mathrm{fl}$ and $\mathrm{f} 2$; vertical lines) for the oddball paradigm; the black horizontal line shows the attenuation level. (b) The oddball paradigm consisted of two sequences of 400 trials each, in which the two frequencies were presented with different probabilities, and reversed between the two sequences. 
The sound frequencies of each pair were chosen to elicit similar spike counts when presented individually, to ensure that all differences in response were due to the statistics of the stimulus ensemble. The same paradigm was repeated varying the probability of the standard/deviant stimuli $(90 / 10 \%$ and $70 / 30 \%)$, the inter-stimulus interval (ISI $=2000 \mathrm{~ms}, 500 \mathrm{~ms}, 250 \mathrm{~ms}$, and $125 \mathrm{~ms}$, onset-to-onset; $75 \mathrm{~ms}$ stimuli duration), and the frequency contrast between the standard and deviant stimulus $(\Delta \mathrm{f})$. The custom software allowed to independently varying these stimulation conditions (probability ratios, frequency contrasts, and repetition rates). I choose the $\Delta \mathrm{fs}$ to be as close as possible to values that have been used in other studies to allow direct comparisons of the data, i.e., $\Delta \mathrm{f}=0.37,0.10$ and 0.04 ; where $\Delta \mathrm{f}=(\mathrm{f} 2-\mathrm{f} 1) /(\mathrm{f} 2 * \mathrm{f} 1)^{1 / 2}$ is the normalized frequency difference (Malmierca et al., 2009; Ulanovsky et al., 2003). These values correspond to frequency ratios of $0.526,0.141$ and 0.057 octaves, respectively.

I used the SSA indices to quantify SSA as described previously (Malmierca et al., 2009; Ulanovsky et al., 2003). I calculated the frequency-specific SSA index, SI(f $\left.f_{i}\right)$ $(\mathrm{i}=1$ or 2$)$, as $\mathrm{SI}(\mathrm{fi})=[\mathrm{d}(\mathrm{fi})-\mathrm{s}(\mathrm{fi})] /[\mathrm{d}(\mathrm{fi})+\mathrm{s}(\mathrm{fi})]$ where $\mathrm{d}(\mathrm{fi})$ and $\mathrm{s}(\mathrm{fi})$ were responses (in spike counts/stimulus) to frequency $\mathrm{f}_{\mathrm{i}}$ when it was deviant or standard, respectively. The amount of SSA for both frequencies at each condition (Common SSA index, CSI) was calculated as CSI $=[\mathrm{d}(\mathrm{f} 1)+\mathrm{d}(\mathrm{f} 2)-\mathrm{s}(\mathrm{f} 1)-\mathrm{s}(\mathrm{f} 2)] /[\mathrm{d}(\mathrm{f} 1)+\mathrm{d}(\mathrm{f} 2)+\mathrm{s}(\mathrm{f} 1)+\mathrm{s}(\mathrm{f} 2)]$. These indices reflect the extent to which the response to a tone, when standard, was smaller than the response to the same tone, when deviant. The indices range between -1 to +1 , being positive if the response to a tone, when deviant, was greater than the response to the same tone, when standard. In the first set of experiments, to thoroughly quantify the conditions that elicited SSA in a given neuron, I calculated the indices for the different combination of conditions tested (probability ratios, frequency contrasts, and repetition 
rates). For each neuron, this resulted in a set of SI(fi) and CSI values for all of the conditions that were tested.

In the AC deactivation experiments, I used only the combination of stimulation conditions that most effectively elicited SSA in the previous set of experiments: a frequency ratio of 0.141 octaves $(\Delta f=0.10)$, presented with $250 \mathrm{~ms}$ ISI and $90 / 10 \%$ probability ratio (standard/deviant). For this reason, all neurons tested in the $\mathrm{AC}$ deactivation experiments were tested for the same stimulation conditions, varying the AC activity condition (control, cool and recovery).

\section{Location of neurons and histological verification of recording sites}

I located the neurons in the MGB based on stereotaxic coordinates, physiological criteria of tonotopicity and response properties (Bordi and LeDoux, 1994b; Bordi and LeDoux, 1994a; Edeline et al., 1999). Moreover, at the end of most experiments (26 out of 34 in the first set of experiments, Part I, all of the 17 cooling experiments, Part II), I performed electrolytic lesions $(5-10 \mu \mathrm{A}$ for 5-10 s) to mark the tracks and recording sites for subsequent histological verification of the localization of the neurons recorded (Malmierca et al., 2009).

I anesthetized the animals with a lethal dose of sodium pentobarbital and perfused them transcardially with phosphate buffered saline $\left(0.5 \% \mathrm{NaNO}_{3}\right.$ in $\left.\mathrm{PBS}\right)$ followed by fixative (a mixture of $1 \%$ paraformaldehyde and $1 \%$ glutaraldehyde in rat Ringer's solution). Then I cutted the brains from the skull, postfixed them in the same solution overnight and crioprotected in $30 \%$ sucrose in $0.1 \mathrm{M} \mathrm{PB}$ solution, for two days, under gentle agitation at $4^{\circ} \mathrm{C}$. I used a freezing microtome (Microm HM 400; Heidelberg, Germany) to section the brains into $40-\mu \mathrm{m}$-thick sections in the transverse 
plane. I collected the serial sections in $0.1 \mathrm{M}$ PB solution for histology. I mounted the sections in gelatine coated slides that after air drying I dehydrated with ethanol and xylene. I Nissl stained the sections using Cresyl Violet (0.1\%; Sigma-Aldrich), to facilitate the identification of cytoarchitectural boundaries (Winer et al., 1999). I coversliped the sections using Entelan as mounting media, and finally examined them using light microscopy (Leica, Wetzlar, Germany).

I used the stained sections with the lesions to localize each track mediolaterally, dorsoventrally and rostrocaudally in the Paxinos rat brain atlas (Paxinos and Watson, 2005). To determine the three main MGB subdivisions (Clerici and Coleman, 1990; Winer et al., 1999) I used Nissl staining patterns as well as cell packing density and cytoarchitectonic criteria, i.e., cell shape and size. I complemented and confirmed this information with the stereotaxic coordinates used during the experiment to localize the MGB. After assigning a section to each track/lesion, I used the electrophysiological coordinates from each experiment and recording unit, i.e., beginning and end of the MGB, as well as the depth of the neuron, as complementary references to localize each neuron within a track. I excluded from the analysis the neurons localized at the border between subdivisions and those recorded in the animals that I did not perfuse. I constructed topographic maps of SSA using Voronoi tessellations of the recording sites (e.g. Kilgard and Merzenich, 1999), based on selected conditions for which a large number of tested neurons were localized $(\Delta \mathrm{f}=0.10$ at ISI $=500 \mathrm{~ms})$. Each polygon of the maps was coloured according to the CSI of the unit recorded at that site.

I photographed two Nissl stained sections showing the MGB in the transverse plane at high resolution with a Zeiss Axioskop 40 microscope using a Zeiss AxioCam MRc 5 digital camera (Carl Zeiss, Oberkochen, Germany) and plan semi-apochromatic 
objective lenses 5x (NA 0.15). I adjusted the brightness and contrast of images with Adobe Photoshop software (Adobe, San José, CA, USA).

\section{Reversible cooling AC deactivation}

I recorded 51 single units from the MGB before, during and after deactivating the ipsilateral AC using the cooling technique. This technique enables the reversible deactivation of discrete regions of the brain (Lomber, 1999a; Lomber et al., 2010; Palmer et al., 2007; Payne et al., 1996; Fig. 10). Is has been extensively used to study functional interactions between cortical areas (e.g., Carrasco and Lomber, 2009a; Carrasco and Lomber, 2009b; Carrasco and Lomber, 2010; Lomber and Payne, 2004; Lomber and Malhotra, 2008; Malhotra et al., 2008) and the corticofugal modulation of subcortical nuclei in various sensory systems (Baker et al., 1977; Ghosh et al., 1994; Lomber et al., 2007; Nakamoto et al., 2008; Nakamoto et al., 2010; Rushmore et al., 2005; Villa et al., 1991; Villa et al., 1999).

Since corticofugal fibres terminating in the MGB are entirely ipsilateral (Bajo et al., 1995; Winer et al., 2001; Winer et al., 2005; Fig. 1), I assumed that ipsilateral AC cooling deactivated all the descending inputs to the MGB. To cool the AC, I used a 4 $\mathrm{mm}$ diameter cryoloop that was made by shaping a loop of 23-gauge stainless steel hypodermic tubing to conform to the AC surface (Lomber et al., 1999; Fig. 10). I positioned the loop stereotaxically over the $\mathrm{AC}$, encompassing both the primary and secondary cortical field (Doron et al., 2002). I deactivated the whole AC in order to avoid specific effects due to partial deactivation.

To achieve cooling I pumped methanol cooled by dry ice through the cryoloop using a peristaltic pump. I monitored the temperature continuously by a 
microthermocouple (Omega HH506RA multiterm) attached to the union of the loop and accurately governed by controlling the flow of methanol, to get a loop temperature of $3^{\circ} \pm 1^{\circ} \mathrm{C}$ (Lomber et al., 1999). A stable cortical temperature was reached in $\sim 5$ min of initiating cooling. I started the MGB recordings 5 min later to ensure deactivation of the deeper AC layers where the corticofugal projection to the MGB originates (mostly form layer VI with a minor proportion from layer V; Bajo et al., 1995; Bartlett et al., 2000; Kimura et al., 2004; Kimura et al., 2005; Kimura et al., 2007; Kimura et al., 2009; Ojima and Rouiller, 2011; Winer and Prieto, 2001; Figs. 6 and 7).

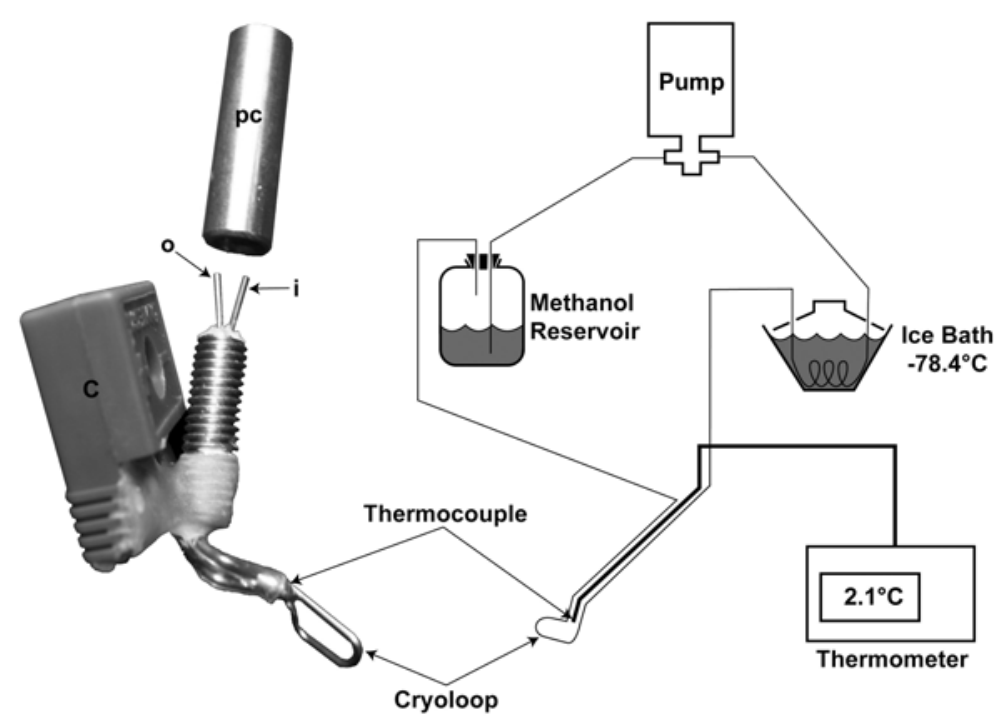

Figure 10. Schematic representation of the cooling setup (from Lomber and McMillan, 2011).

Cooling the cryoloop to $3 \pm 1{ }^{\circ} \mathrm{C}$ is sufficient to deactivate all six layers of cortex beneath the cryoloop (Lomber et al., 1999; Lomber and Payne, 2000; Lomber et al., 2007) as it places the critical $20^{\circ} \mathrm{C}$ deactivation isotherm necessary to block synaptic transmission at the gray-white matter interface or deeper (Lomber et al., 1999). I confirmed such deactivation in selected cases (3 animals) where AC responses were 
recorded up to $1000 \mu \mathrm{m}$ in depth, corresponding to layers V/VI in rat (Games and Winer, 1988b; Fig. 5 and 6) by the cessation of activity, as recorded by microelectrodes.

I recorded continuously the responses of the MGB neurons (FRAs and SSA, in an alternate order) during $\sim 15$ min of AC deactivation, after which I turned off the cryoloop pump. The normal AC surface temperature was regained in a few min, though cortical and MGB responses took longer to return to normal (Nakamoto et al., 2008). After $30 \mathrm{~min}$, the responses of the neurons returned to normal, since cooling disrupts neither the structural nor functional integrity of the cooled area (Lomber et al., 1999; Lomber, 1999; Yang et al., 2006).

I removed from all analysis the few neurons (3 out of 51) that did not recover to within $20 \%$ of the pre-cooling maximum spike count. In some neurons I observed a moderate higher firing rate in the recovery, a rebound presumably due to a higher synaptic release probability during re-warming (Volgushev et al., 2004).

\section{Data analysis}

In the first set of experiments, in order to analyse SSA across MGB subdivisions I performed a fixed-effect 3-way ANOVA (factors: subdivisions x $\Delta \mathrm{f}$ x ISI), followed by Post hoc comparisons (Tukey's HSD, $p<0.05$ ). To analyse the effect of neuron on SSA I performed the 3-way ANOVA augmented into a nested design (neurons within subdivisions). To analyse the effects of neuron, $\Delta \mathrm{f}$ and ISI on SSA within subdivisions, I performed 3-Way ANOVAs for each subdivision separately, with neurons considered as a random factor. I have done all analyses using the statistical toolbox of Matlab (MathWorks). 
In the $\mathrm{AC}$ deactivation experiments, I used the non-parametric (two-sided) Wilcoxon signed rank test to test differences between distribution medians of varying conditions (warm, cool and recovery). I performed multiple comparisons by using TwoWay Repeated Measures ANOVAs (One factor repetition; repeated factor: condition). I performed the correlation coefficients using Pearson's correlation. I calculated the standard deviation $(S D)$ for the CSI of each individual neuron using 1000 repetition bootstrapping. I have done the analyses using the statistical toolbox of Matlab (MathWorks) and Sigmaplot 11 (Systat Software, Inc).

In all experiments, I considered statistical tests to be significant when $p<0.05$. I have done the analysis and figures using Matlab (MathWorks) and Sigmaplot 11 (Systat Software, Inc). 
RESULTS 
My PhD research focused on characterising SSA throughout the MGB and on examining if the AC exerts an effect on the SSA exhibited by neurons in this thalamic nucleus. To achieve these goals, I performed two series of experiments, that are described in two separate parts: In the first part I will describe the results of the experiments conducting to the characterization of SSA in the MGB, using the oddball paradigm; and in the second part the results of the experiments in which I reversibly deactivated the AC by cooling, to silence its neurons and the descending (ipsilateral) projections to the auditory thalamus. 
To characterize SSA in the MGB I recorded the responses of single neurons $(n=93)$ in the anesthetised rat, while stimulating the animals with an oddball paradigm. This paradigm was developed by Ulanovsky and colleagues (2003) and consisted of sequences of tones with two different frequencies (f1 and $\mathrm{f} 2 ; 400$ stimulus presentations) each of which presented with two different probabilities, one common (standard) and one rare (deviant), interleaved in the sequence (Fig. 9). I used two different probability ratios for the standard and deviant frequencies $(90 / 10 \%$ or $70 / 30 \%)$, as well as different frequency intervals between the standard and deviant $(\Delta \mathrm{f}=$ $0.37,0.10$ or 0.04 ) and different repetition rates (ISIs $=2000 \mathrm{~ms}, 500 \mathrm{~ms}, 250 \mathrm{~ms}$ or 125 $\mathrm{ms}$; onset-to-onset, for a $75 \mathrm{~ms}$ tone duration). To determine if SSA in the MGB varies with the subdivision where the neurons were localized I have done electrolytic lesions at the end of the experiments and processed the brains histologically. Based on Nissl stained sections, I localized 60 of the 93 units recorded to one of the three main MGB subdivisions: 24 units were localized to the MGD; 18 to the MGM; and 18 to the MGV. The remaining units could not be localized with confidence and included units close to the borders between subdivisions (15 out of 33 ).

My main finding in this work is that many neurons in the MGB showed a much stronger response to the deviant than to the standard stimulus, i.e., they adapted specifically to the standard stimulus (Fig. 1a), indicating the presence of strong SSA in the auditory thalamus. I have also found some neurons that did not show SSA in the MGB. These neurons without SSA had a similar response to the standard and to the deviant stimulus (Fig. 1b). 

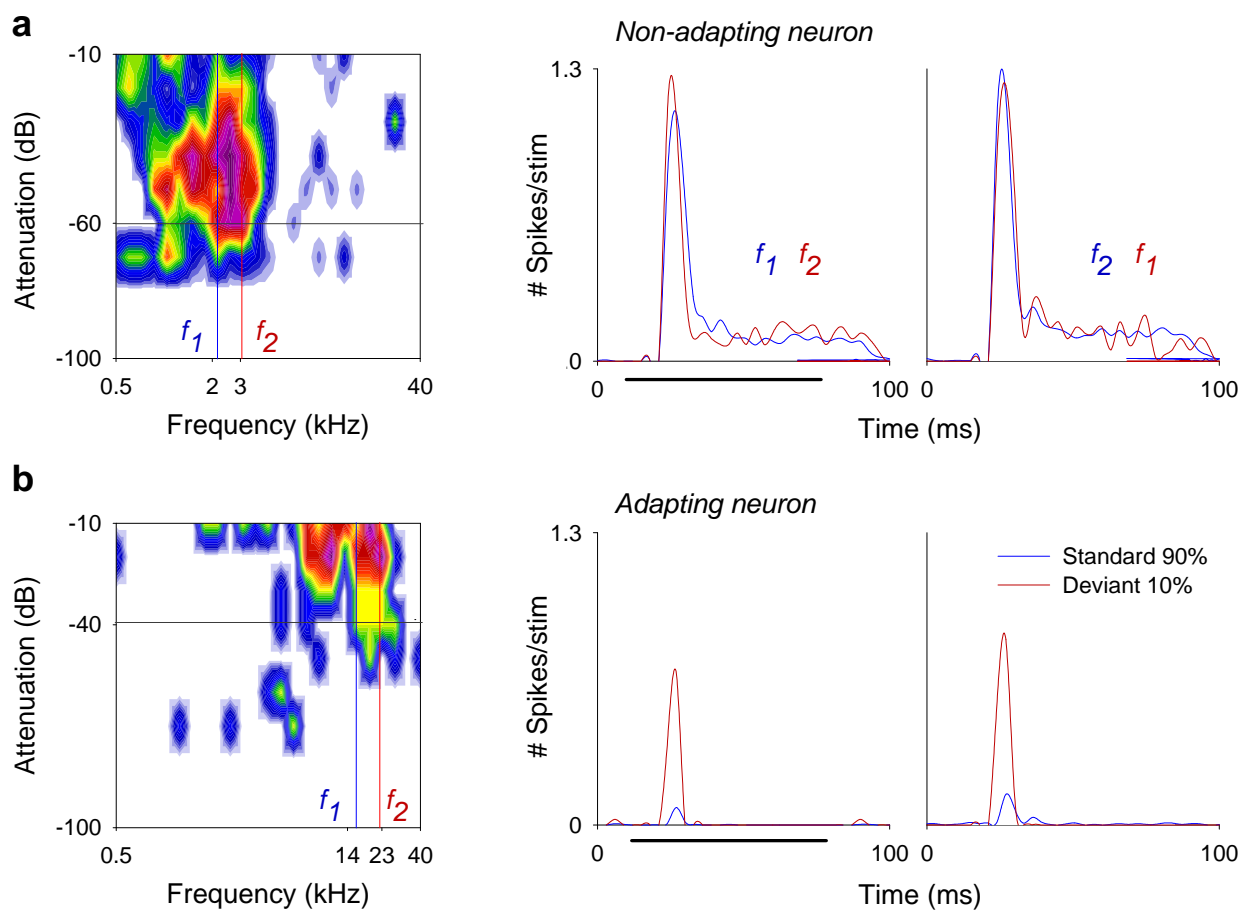

Figure 11. Response of two neurons to pure-tone stimuli of two frequencies ( $\mathrm{f} 1$ and $\mathrm{f} 2$ ), selected from within the frequency response area of the neuron (left panels), presented in an oddball paradigm (ISI $=500 \mathrm{~ms} ; \Delta \mathrm{f}=0.37$ ). Red and blue lines in the peri-stimulus time histograms (PSTHs; second and third panels) represent the neuronal activity (number of spikes/stimulus; bin duration: $3 \mathrm{~ms}$; number of bins: 168$)$ elicited by the deviant tone (10\% probability) and standard tone (90\% probability) respectively, in the first block of stimuli (left PSTHs; f1 as standard, f2 as deviant) and in the second block of stimuli (right PSTHs; $\mathrm{f} 2$ as standard, $\mathrm{f1}$ as deviant). Black horizontal lines below the PSTHs in the second panels indicate the duration of the stimulus $(75 \mathrm{~ms})$. The non-adapting neuron (a) has a similar response to the standard and to the deviant frequencies in both blocks of stimuli. In contrast, the adapting neuron (b) shows a much stronger response to the deviant than to the standard frequency in both blocks of stimuli.

\section{The common SSA index (CSI) to quantify SSA}

I have quantified the degree of SSA exhibited by the MGB neurons, by calculating the common SSA index (CSI) of each neuron, for each condition tested, as developed by Ulanovsky and colleagues (2003). In order to illustrate how CSI vary with the responses of the neurons, I plotted the responses evoked by the deviant versus the standard stimulus, and used different colors for the different CSI values obtained (Fig. 12). This figure shows the responses of the neurons to all conditions tested. For this reason, there 
are more data points than the number of neurons recorded $(n=372$ data points for the 93 neurons recorded). For those neurons having CSI values close to 0 (blue) for a certain condition, the responses elicited by the standard were similar to those elicited by the deviant stimulus. Since the negative values found were so close to zero, they are probably the result of variability in the spike counts. For this reason, I took the most negative CSI value in the data set, -0.18 , to represent the most extreme variance due to random fluctuations in spike counts. Using this measure, I consider the range of CSI between -0.18 and +0.18 as indicating lack of adaptation. CSI values greater than 0.18 indicate that a neuron showed a stronger response to a given stimulus when it was presented as the deviant relative to the response when it was presented as the standard, i.e., the neuron showed SSA. CSI values close to +1 (red color) indicate near-complete cessation of the responses to the standards (Fig. 12).

\section{Responses of the population of MGB neurons across stimulation conditions}

To determine if the discharge rate of the MGB neurons varied with the stimulation conditions I calculated the average responses of the entire population for the different frequency contrasts and repetition rates tested at the 90/10\% standard-todeviant probability ratio (Fig. 13). On average, the firing rate decreased as the ISI decreased, i.e., firing rate was highest at low stimulus repetition rates. Since this effect occurred in the responses evoked by both the standard and the deviant stimulus, it presumably represents a form of non-specific adaptation that affects similarly the responses to all stimuli. 


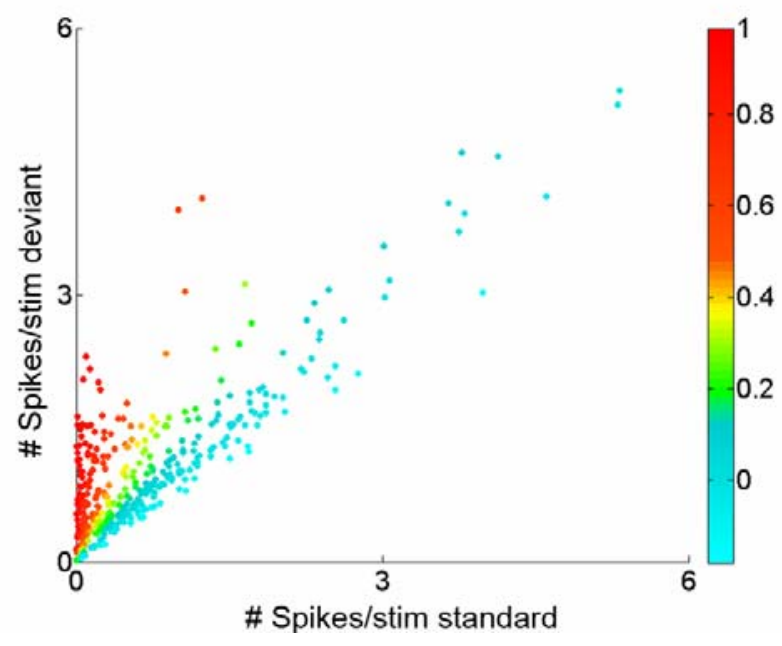

Figure 12. Responses of MGB neurons to the deviant and standard tones across the CSI range. Scatterplot of the response of all neurons to the deviant tone vs response to the standard tone, with points color-coded according to the CSI value (different colors, right color bar). Low CSI values (around 0 ) correspond to neurons having a similar response to the standard and deviant stimuli, i.e., non-adapting neurons. Higher CSI values reflect a stronger response to the deviant than to the standard stimulus, i.e., adaptation to the standard. CSI values close to +1 (red color) indicate near-complete cessation of the responses to the standard tone. The most strongly responding neurons tended to be non-adapting.

The neurons that had the largest overall reduction in their responses at high repetition rates where those that exhibited the highest levels of SSA at the intermediate repetition rates (ISI $=250$ and/or $500 \mathrm{~ms}[4 / \mathrm{s}$ or $2 / \mathrm{s}]$ ). In the extreme case, many units (27/47) that exhibited high levels of SSA for an ISI of $250 \mathrm{~ms}$ completely ceased firing at the shortest ISI $(125 \mathrm{~ms})$. These units were not included in the analysis for this condition. For this reason, the data collected at the highest repetition rate tested (ISI $=$ $125 \mathrm{~ms}[8 / \mathrm{s}])$ required special treatment. The remaining units (20/47) maintained some firing when tested at the $125 \mathrm{~ms}$ ISI condition, resulting in high CSI values for all these conditions. Figure 14 displays the responses of one of these high-SSA neurons, localized in the MGM subdivision. This neuron reduced substantially but not completely its responses when stimulated at the highest repetition rate (ISI $=125 \mathrm{~ms})$. 


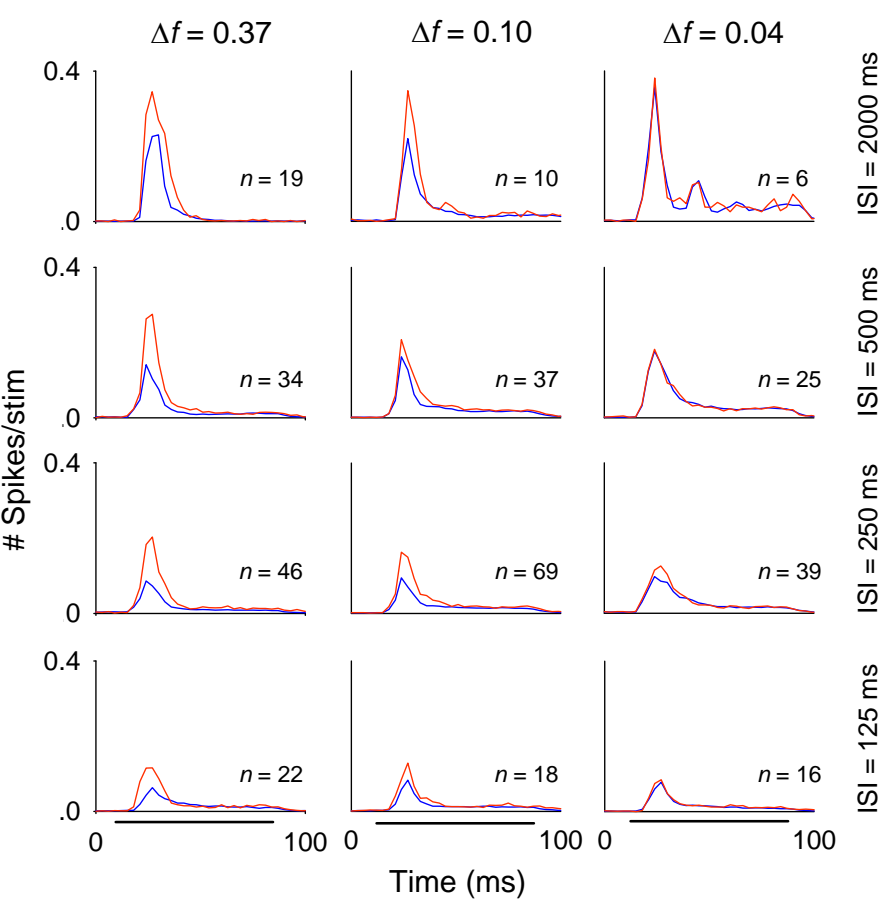

Figure 13. Averaged post-stimulus time histograms (Bin duration: $3 \mathrm{~ms}$ ) for the entire population of MGB neurons across the different conditions tested ( $\Delta \mathrm{f}$ and ISI) for the $90 / 10 \%$ probability condition. The mean firing rate elicited by both stimuli (standard, blue lines; deviant, red lines) decreased directly with ISI (ISI $=2000,500,250$ and $125 \mathrm{~ms}$; from first to fourth rows, respectively), for the different $\Delta \mathrm{fs}$ tested ( $\Delta \mathrm{f}=0.37,0.10$ and 0.04 ; from first to third columns, respectively). Numbers in each plot indicate the number of neurons for each condition. Black horizontal lines under the PSTHs of the bottom row indicate the duration of the stimulus (75 ms).

The population analysis shows that the mean firing rate in response to the deviant was significantly higher than that to the standard under all conditions, except when $\Delta f$ was 0.04 (with a small effect for ISI $=250 \mathrm{~ms}$; i.e., at a repetition rate of $4 / \mathrm{s}$; Fig. 13). This indicates the presence of neurons exhibiting SSA in all but the smallest $\Delta f$ condition. However, a population analysis of this type is biased disproportionately by neurons with high firing rates. Since the neurons with the largest responses tended to be non-adapting (e.g., compare neurons in Fig. 11a and b, tested for the same conditions; see Fig. 12 for population analysis), the responses of the highly-adapting neurons with lower firing rates are downplayed in Fig. 13. Next, I analyzed the responses of each neuron under each condition tested in order to quantify and describe SSA across the MGB population. 

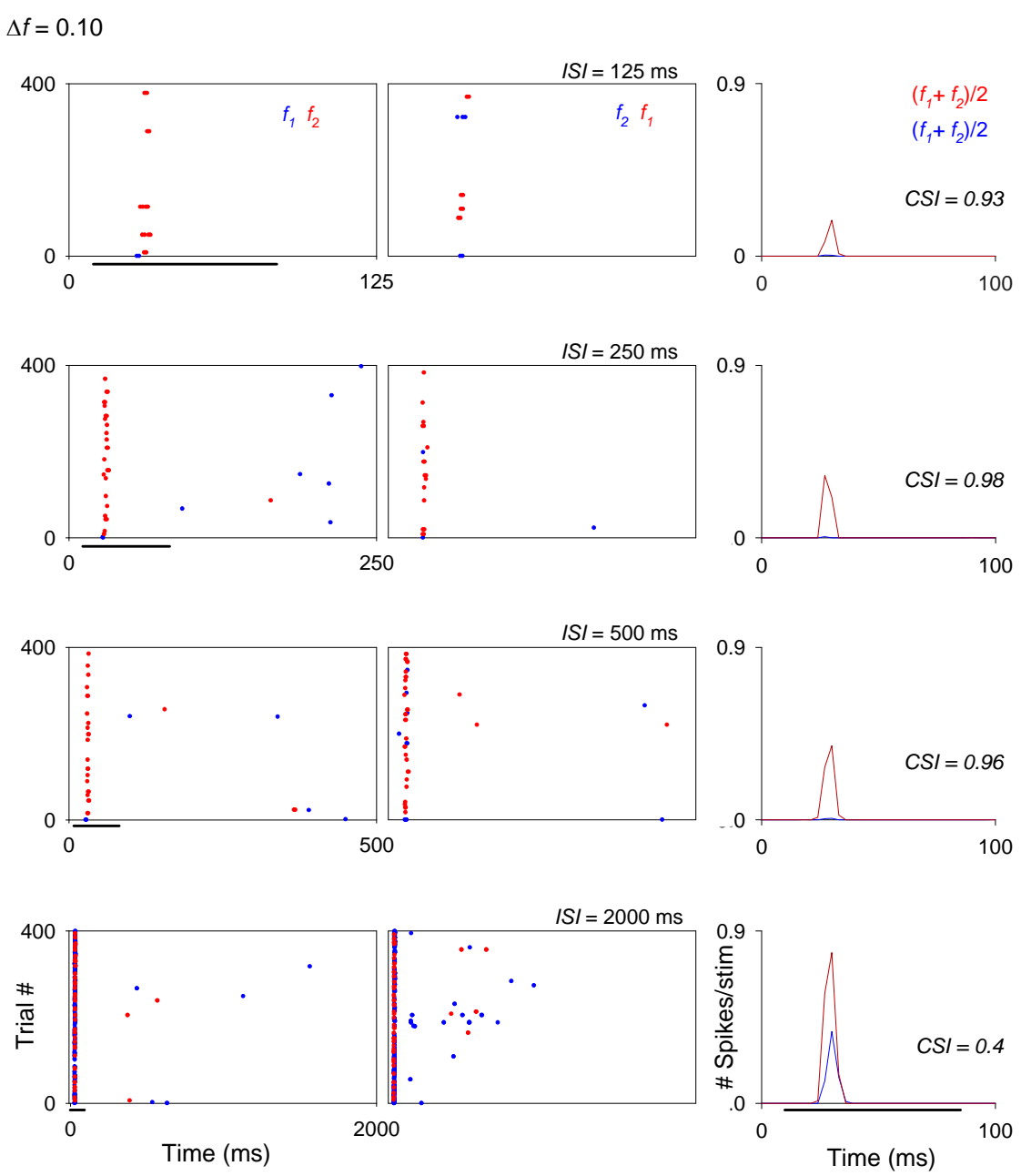

Figure 14. Example of an MGM neuron showing strong SSA across different ISIs $(125,250$, 500 and $2000 \mathrm{~ms}$; from the first to the fourth rows, respectively) at the same $\Delta \mathrm{f}(0.10)$. The firing rate of this neuron decreased with decrease in ISI, it exhibited strong SSA even under extreme conditions, i.e., at the combination of a $\Delta \mathrm{f}=0.10$ and ISI $=2000 \mathrm{~ms}$ (fourth row). In this figure and subsequent ones (e.g., Figs. 6, 8, 9, 11 and 13), the plots show responses as dot rasters, which plot individual spikes (red dots indicate responses to the deviant; blue dots indicate responses to the standard). Stimulus presentations are stacked along the y-axis (trial \#; 400 trials each block). The time (ms) between trials (ISI) corresponds to the $\mathrm{x}$-axis and is also indicated at the top right of each pair of raster plots. Because we tested different ISIs, the plots in the different rows have different $\mathrm{x}$-axis scales corresponding to the ISI tested. Left and middle columns in each row represent the two blocks tested for each frequency pair ( $\mathrm{fl} / \mathrm{f} 2$ as standard/deviant; and f2/f1 as standard/deviant, respectively). PSTHs in the right column show the number of spikes/stimulus averaged over the two blocks $[(\mathrm{f} 1+\mathrm{f} 2) / 2$; when standard, blue line; when deviant, red line]. Black horizontal lines under the plots indicate the duration of the stimulus ( $75 \mathrm{~ms}$ ). The CSI calculated for each ISI condition (each row) is noted as inset on the PSTHs. 


\section{General characterization of SSA across the MGB population}

To characterize SSA in the MGB neurons, I calculated the frequency-specific SSA index (SI) for the different conditions tested separately (Fig. 15; the different colors in the plots indicate the neurons that were located in the different MGB subdivisions: Red, MGM; Orange, MGD; Blue, MGV; and Gray, non-localized units). For the majority of conditions, the plots show SI(fi) values located above the reverse diagonal, which indicates the presence of SSA (Ulanovsky et al., 2003). Since we selected two frequencies for the oddball sequence that elicited a similar firing rate in each neuron, the SI values for each frequency pair [SI(f1) and SI(f2)] were very similar, leading to a distribution around the diagonal in the upper right quadrant of the plot for most of the values (Fig. 15); this demonstrates that the response did not depend on the frequencies presented, but reflected genuine adaptation elicited by the standard-deviant combination.

In the whole population, the highest SSA values were found for the largest $\Delta \mathrm{fs}$ (0.37 and 0.10$)$ at intermediate ISIs $(250$ and $500 \mathrm{~ms})$ and the lowest deviant probability $(90 / 10 \%)$ conditions (Fig. 15). The plots for these conditions show a cluster of points in the upper right corner (Fig. 15); these points correspond to neurons with an SI(fi) $>0.6$ for both $\mathrm{f} 1$ and $\mathrm{f} 2$. These neurons represent the highest degree of selectivity to the rare tone. Under these conditions, a high percentage of neurons showed CSI values in the range from 0.6 to 0.99 , demonstrating strong SSA $(56 \%$ and $27 \%$ at ISI $=500$, for $\Delta \mathrm{f}=$ 0.37 and 0.10 , respectively; $46 \%$ at ISI $=250 \mathrm{~ms}$ for both $\Delta \mathrm{fs}$; Fig. 15). Figures 14 and 16 show two examples of the responses of such neurons, localized to the MGM and MGD, respectively (For the units in Figs. 14 and 16, CSI $>0.82$ when $\Delta f \geq 0.1$ and ISI $=250$ or $500 \mathrm{~ms}$ ). As I explained before, some neurons failed to respond at all for the shortest ISI $(125 \mathrm{~ms})$ and for this reason fewer neurons are represented in these plots 
(Fig. 15). Even so, some neurons maintained a high degree of SSA under this condition (Fig. 14 , first row; $\Delta \mathrm{f}=0.1$ and $\mathrm{SOA}=125 ; \mathrm{CSI}=0.93$ ).

The amount of SSA was reduced for the largest ISI $(2000 \mathrm{~ms})$ and the smallest $\Delta \mathrm{f}(0.04)$ tested. Nevertheless, we recorded neurons that exhibited robust SSA under each of these extreme conditions (Fig. 15). Figure 14 shows the responses of a neuron that had a reduced, but still high degree of adaptation at an ISI of $2000 \mathrm{~ms}$ (fourth row: $\Delta \mathrm{f}=0.10, \mathrm{CSI}=0.40 ;$ compared to CSI $>0.9$ for shorter ISIs). Other neurons had CSI $>$ 0.6 at the largest ISI $(2000 \mathrm{~ms})$. For the smallest $\Delta \mathrm{f}(0.04)$ some neurons had CSI $>0.6$ as well (for ISI $=250 \mathrm{~ms}$ and $500 \mathrm{~ms}$, respectively; Fig. 15). Figure 16 shows an example of a neuron that had a reduced, but still high degree of adaptation with $\Delta \mathrm{f}=$ $0.04(\mathrm{ISI}=250 \mathrm{~ms}, \mathrm{CSI}=0.58)$. However, no neurons showed SSA when tested with the combination of $\Delta \mathrm{f}=0.04$ and $\mathrm{SOA}=2000 \mathrm{~ms}$. This was in fact the only combination out of the 15 tested that did not elicit any SSA in the MGB population (Fig. 15).

Although some neurons exhibited high SI values under the $70 / 30 \%$ condition, they were lower than for the $90 / 10 \%$ condition at the same ISI and $\Delta$ fs (Fig. 15; compare row 3 and row 5). Therefore, lower deviant probabilities in the sequence elicited higher degrees of SSA. 


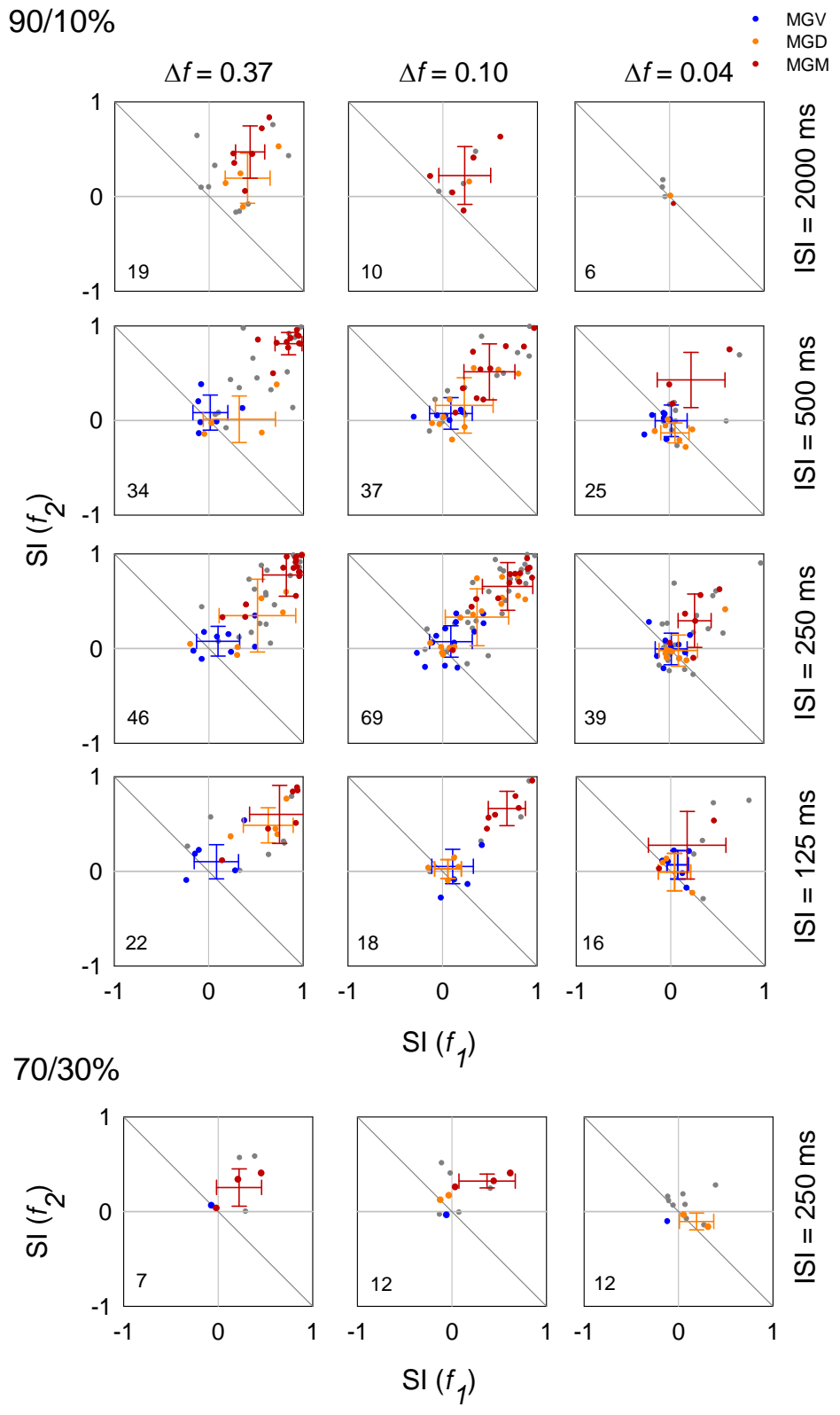

Figure 15. Analysis of SSA across MGB subdivisions in the population of recorded neurons. Scatterplots of SI(f1) versus (f2), for the different $\Delta \mathrm{fs}(0.37,0.10$ and 0.04 , from first to third columns), ISIs (2000 ms, $500 \mathrm{~ms}, 250 \mathrm{~ms}$, and $125 \mathrm{~ms}$, from first to fourth rows) and probabilities tested $(90 / 10 \%$ and $70 / 30 \%)$. Each dot in each panel represents data from one neuron. Neurons that were tested for more than one set of conditions are represented in more than one panel. Numbers in the lower left quadrant of the plots represent the number of neurons tested for each condition. Blue dots represent neurons from the MGV; yellow from the MGD and red from the MGM. Grey dots represent neurons that could not be assigned with certainty to one subdivision. Crosses indicate the mean and standard deviation for the localized neurons (blue for MGV; orange for MGD; and red for MGM). For the majority of conditions SI (fi) values lie above the reverse diagonal indicating the presence of SSA. SSA was strongest for the intermediate ISIs (205 and $500 \mathrm{~ms}$ ), the largest $\Delta \mathrm{fs}(0.37$ and 0.10$)$ and the $90 / 10 \%$ conditions. SSA was strongest in the MGM, intermediate in the MGD and weaker in the MGV subdivision. 

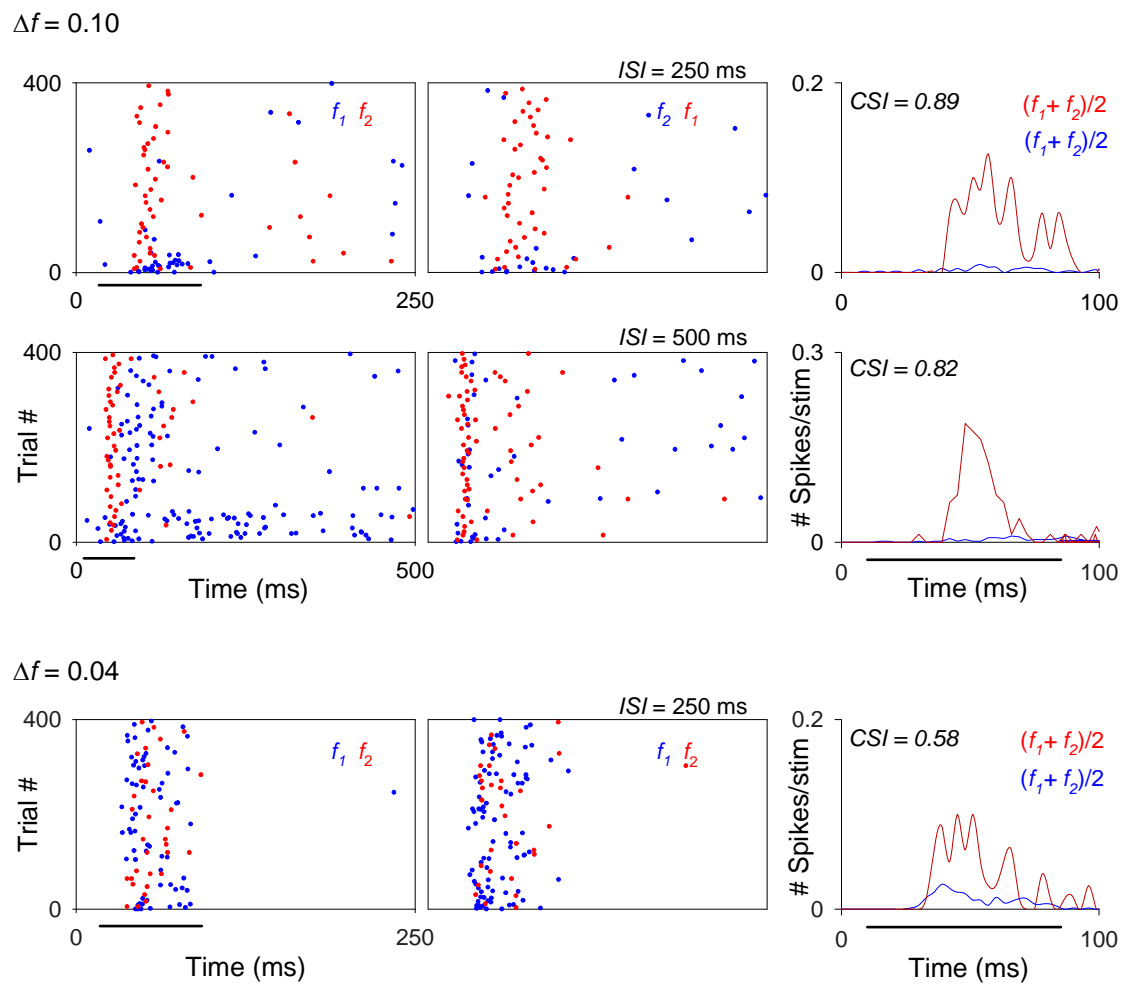

Figure 16. Example of sustained responses recorded from a neuron in the MGD, exhibiting high levels of SSA when tested at two different $\Delta \mathrm{fs}(0.10$, first and second rows; 0.04 , third row). This neuron had a reduced but still high degree of adaptation for the smallest $\Delta \mathrm{f}$ tested $(0.04)$, revealing its ability to discriminate between two very close frequencies. Details of dot rasters and PSTHs are the same as in figure 14.

\section{Characterization of SSA across MGB subdivisions}

The degree of SSA varies across MGB subdivisions: neurons located in the MGM showed the highest SI values; followed by neurons located in the MGD with intermediate values; and finally neurons in the MGV with the lowest values (Fig. 15, red, orange and blue dots, respectively). Figure 17A shows Nissl stained-sections of the MGB with marked electrolytic lesions, corresponding to the location of neurons recorded in the different MGB subdivisions. To analyze the topographical organization of SSA within the MGB subdivisions, I constructed Voronoi tessellations (Kilgard and Merzenich, 1999) for the combination of conditions for which the sample was largest $(\Delta \mathrm{f}=0.10$ at ISI $=500 \mathrm{~ms}$; Fig. 17B $)$, using a color scale for the CSI values as in Figure 
2. This analysis confirmed that SSA was strongest throughout the entire medial subdivision (MGM) followed by the caudal, medial and dorsal regions of the dorsal subdivision (MGD) (Fig. 17B). SSA was weaker in the ventral subdivision (MGV), being essentially non-existent in the center and somewhat greater in the periphery (Fig. 17B).

To look for statistically significant effects on the CSI and interactions between subdivisions and the conditions tested I performed a 3-Way ANOVA using the 90/10\% probability condition data. The analysis of CSI across subdivisions (factors: subdivision $\mathrm{x} \Delta f \mathrm{x}$ ISI) indicated that all the factors had significant effects on the CSI $\left[F_{(2,211)}=89.6\right.$, $F_{(2,211)}=28.4$ and $F_{(3,211)}=7.6$, respectively; $p<0.001$ in all cases]. Post hoc comparisons (Tukey's HSD, $p<0.05$ ) confirmed that the average CSI in the MGV (0.01) was not different from zero and was significantly smaller than that in the MGM and in the MGD (0.52 and 0.17, respectively); SSA in the MGM was significantly larger than in the MGD as well. CSI was significantly dependent on $\Delta f$, and decreased monotonically with $\Delta \mathrm{f}$ (mean CSI $0.39,0.25$ and 0.07 for $\Delta \mathrm{f}=0.37, \Delta \mathrm{f}=0.1$ and $\Delta \mathrm{f}=$ 0.04, respectively; all significantly larger than 0 , and all pairwise differences significant). SSA depended significantly on the ISI and was smaller for the largest ISI (2000 ms; mean 0.06) than for the other ISIs $(0.25,0.34$ and 0.29 for ISI $=500 \mathrm{~ms}, 250$ $\mathrm{ms}$ and $125 \mathrm{~ms}$ respectively); SSA levels at the three faster rates were not significantly different from each other. 
A
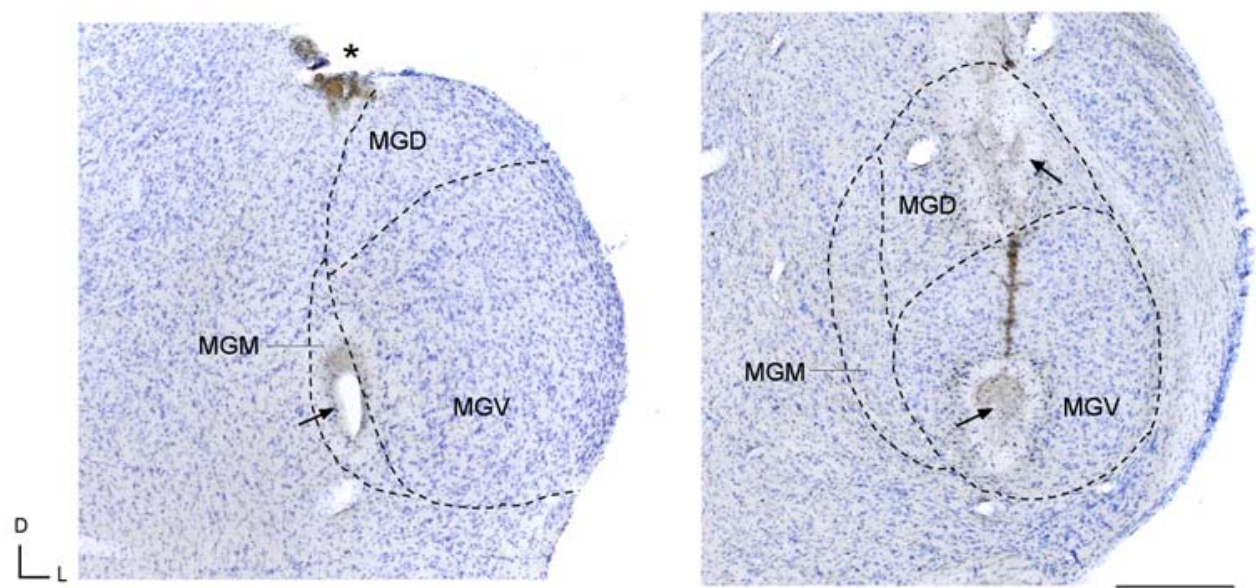

B
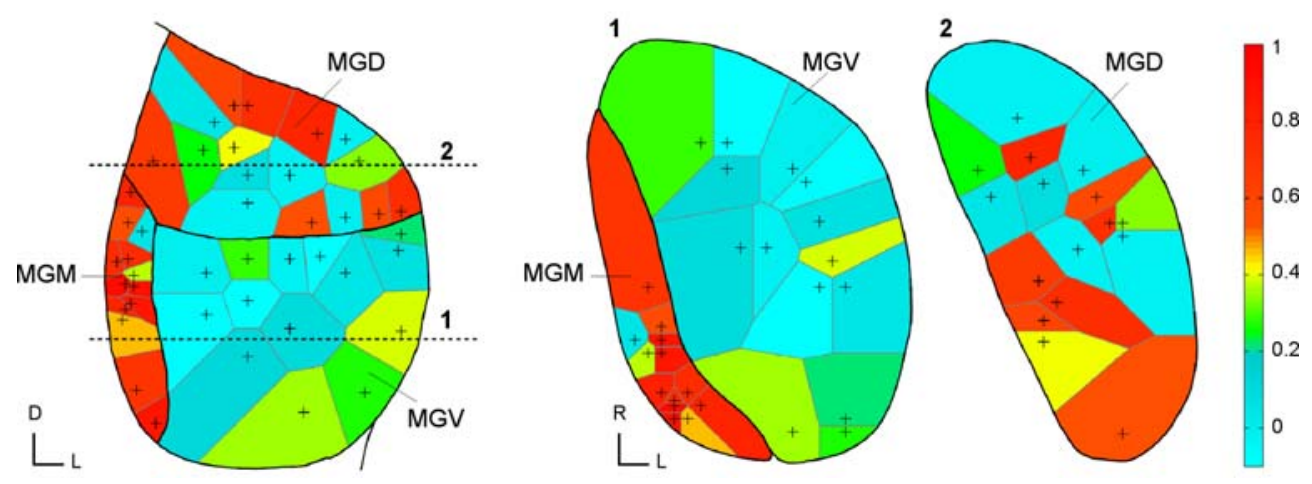

Figure 17. (A) Nissl stained sections showing the MGB in the transverse plane. On the left (caudal), arrows indicate the electrolytic lesion in the MGM marking the recording site of the neuron shown in figure 19. Asterisk indicates another lesion for reference. On the right (rostral), arrows indicate an electrolytic lesion in the MGD and another one in the MGV, marking the recording site of the neuron shown in figure 18. Asterisk shows the recording track. D, dorsal; $\mathrm{L}$, lateral; Calibration bar $=500 \mu \mathrm{m}$. (B) Topographical organization of SSA within the MGB subdivisions, for the $\Delta \mathrm{f}=0.10$ at ISI $=500 \mathrm{~ms}$ condition. The centre of tessellated polygons in the maps represents the sites at which the neurons were recorded. Each polygon was coloured according to the CSI value of the neuron recorded at that site. The bar on the right represents the colour scale used for the CSI range. Both the transverse projection (on left) and the horizontal projections through the MGV/MGM (section 1) and MGD (section 2) show that SSA was strongest throughout the entire MGM followed by the caudal, medial and dorsal regions of the MGD. SSA was weaker in the MGV, being essentially non-existent in its centre and somewhat greater in its periphery. 
Then, I looked for interactions between the different factors. In this analysis, the data corresponding to ISI $=2000 \mathrm{~ms}$ were removed because this condition was not tested in the MGV subdivision at all. The main effects of subdivision and $\Delta \mathrm{f}$ were similar to the previous analysis (both the order and the significance of the pairwise comparisons were preserved in the presence of possible interactions). The ISI had a non-significant main effect $\left[F_{(2,182)}=2.6 ; p=0.08\right]$. This was not surprising given the finding that only the ISI $=2000 \mathrm{~ms}$ condition had significantly different SSA from the other ISIs. The only significant interaction was between subdivision and $\Delta f\left[F_{(4,182)}=\right.$ 3.97; $p<0.01$ ]. Post hoc comparisons (Tukey's HSD) revealed that in the MGV the average CSI at all $\Delta$ fs were not significantly different from 0 and from each other $(0.11$, 0.07 and 0.02 for $\Delta f=0.37,0.1$ and 0.04 respectively); In the MGD the mean CSI at $\Delta f$ $=0.04$ was not significantly different from $0(0.005)$, but at the other $\Delta$ fs was larger than 0 (0.36 and 0.23 for $\Delta f=0.37$ and 0.10 , respectively); in the MGM the mean CSI at all three $\Delta \mathrm{fs}$ were significantly larger than $0(0.79,0.61$ and 0.29 for $\Delta \mathrm{f}=0.37,0.1$ and 0.04 respectively). Furthermore, in both MGD and MGM, the effects at $\Delta \mathrm{f}=0.04$ were significantly smaller than at the other two $\Delta \mathrm{fs}$; the effect at $\Delta \mathrm{f}=0.37$ was larger than at $\Delta \mathrm{f}=0.1$, but the two were not significantly different from each other in any subdivision.

\section{Characterization of SSA within MGB subdivisions}

The CSI values for the same neuron under different conditions tended to be correlated. However, the previous analysis did not account for a possible effect of neuron on $\Delta f$ and ISI, and therefore is conservative. Here, I analyzed the effect of neuron on SSA by performing a 3-Way ANOVA with a nested design (introducing units within 
subdivisions). This analysis demonstrated a strong effect of neuron on the variation of $\operatorname{SSA}\left(F_{(73,138)}=5.26 ; p<0.0001\right)$.

Next, I looked for the effects of neuron, $\Delta f$, and ISI on SSA within the different subdivisions: I performed 3-Way ANOVAs for each subdivision separately, with the neurons as a random factor. This analysis demonstrated a significant effect of neuron in each subdivision separately $\left[F_{(21,39)}=2.75 ; p<0.01 ; F_{(28,34)}=14.92 ; p<0.001\right.$; and $F_{(24,56)}=3.10 ; p<0.001$, for the MGV, MGD and MGM respectively]. Within subdivisions, after controlling for neuron, the effect of $\Delta \mathrm{f}$ was not significant in the ventral and dorsal subdivisions $\left[F_{(2,21)}=2.06 ; p=0.1\right.$ and $F_{(2,34)}=1.69 ; p=0.2$, respectively], but was significant in the medial subdivision $\left[F_{(2,56)}=5.06 ; p<0.01\right]$. These results are consistent with the analysis of the interactions between $\Delta \mathrm{f}$ and subdivision presented above, which showed that the effect of $\Delta \mathrm{f}$ was more pronounced in the MGM, weaker in the MGD and absent in the MGV. Most importantly, the analysis within subdivisions reveals a strong effect of ISI. CSI had a monotonicallyinverse relationship with ISI in all three subdivions $\left[F_{(2,39)}=5.49 ; p<0.01 ; F_{(3,34)}=\right.$ $21.78 ; p<0.001$; and $F_{(3,56)}=10.47 ; p<0.001$, for the MGV, MGD and MGM respectively].

Post hoc comparisons showed that in the MGV, SSA at the shortest ISI (125 ms) was significantly larger than at ISI $=250 \mathrm{~ms}$; the other comparisons were not significant. Figure 18 shows an example of a neuron, localized to the MGV, that exhibited SSA at ISI $=125(\mathrm{CSI}=0.34$; first row $)$ but not at $\mathrm{ISI}=250 \mathrm{~ms}(\mathrm{CSI}=0.03$; not shown) or ISI $=500 \mathrm{~ms}(\mathrm{CSI}=0.03$; second row). In the MGD, as in the MGV, SSA at ISI of $125 \mathrm{~ms}$ was significantly larger than at $250 \mathrm{~ms}$. In the MGM, on the other hand, there was no significant difference between ISIs of 125, 250 and 500 ms. Figure 14 shows an example of a neuron, localized to the MGM, that exhibited the same degree 
of adaptation for all of these different ISIs (first, second and third rows; 125, 250 and $500 \mathrm{~ms}$, respectively). In the MGD and the MGM, SSA at the longest ISI (2000 ms) was significantly reduced with respect to the other ISIs. Figure 19 shows an example of a neuron, localized to the MGM, that showed reduced CSI at the longest ISI (second row in a and b) compared to shorter ISIs (first row in a and b), for two different $\Delta \mathrm{fs}(0.37$ and 0.10$)$.
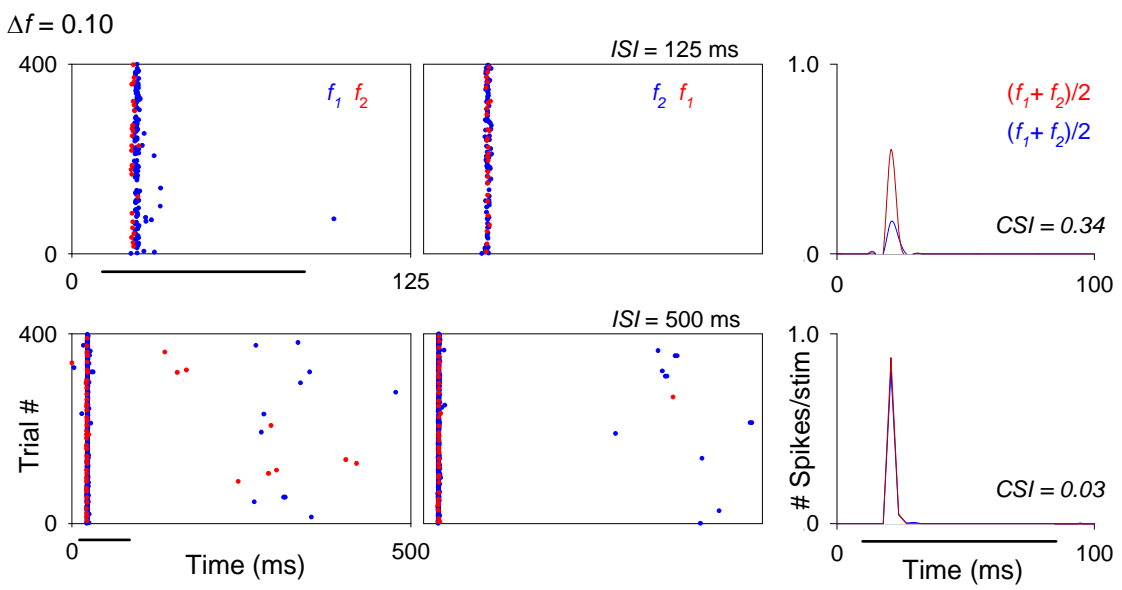

Figure 18. Example of an onset neuron from the MGV tested at two different ISIs (500 and $125 \mathrm{~ms})$ for the same $\Delta \mathrm{f}(0.37)$. This neuron did not show SSA for the longest ISI tested (500 ms, second row) but did show some adaptation at the shortest ISI (125 ms, first row). Details of dot rasters and PSTHs are the same as in figure 14. The location of this neuron is shown in figure 17A. 

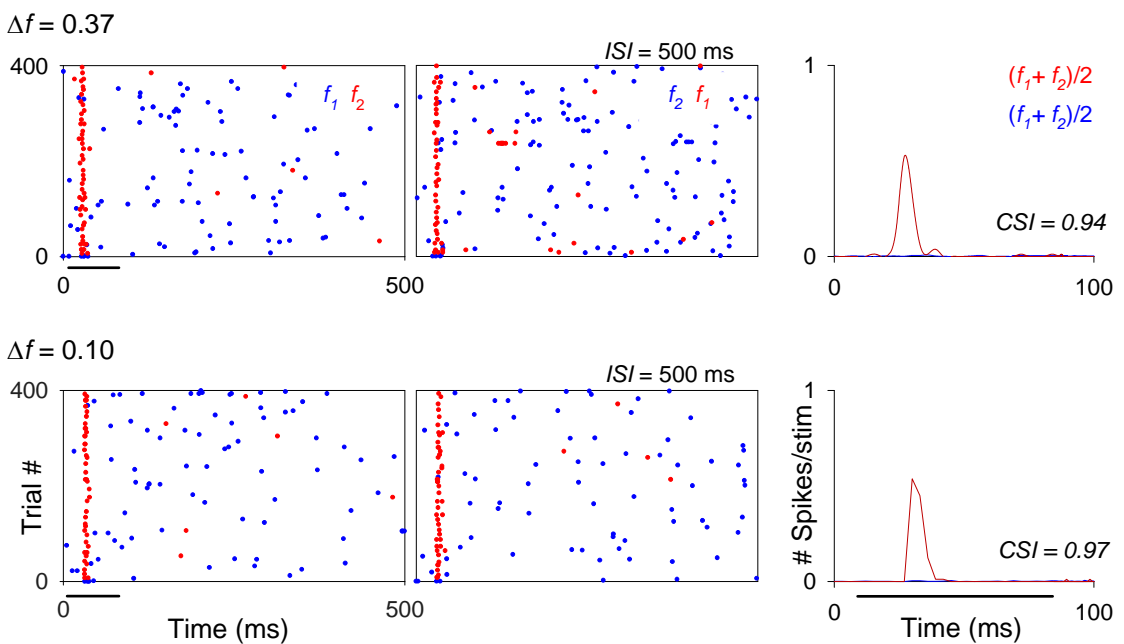

b
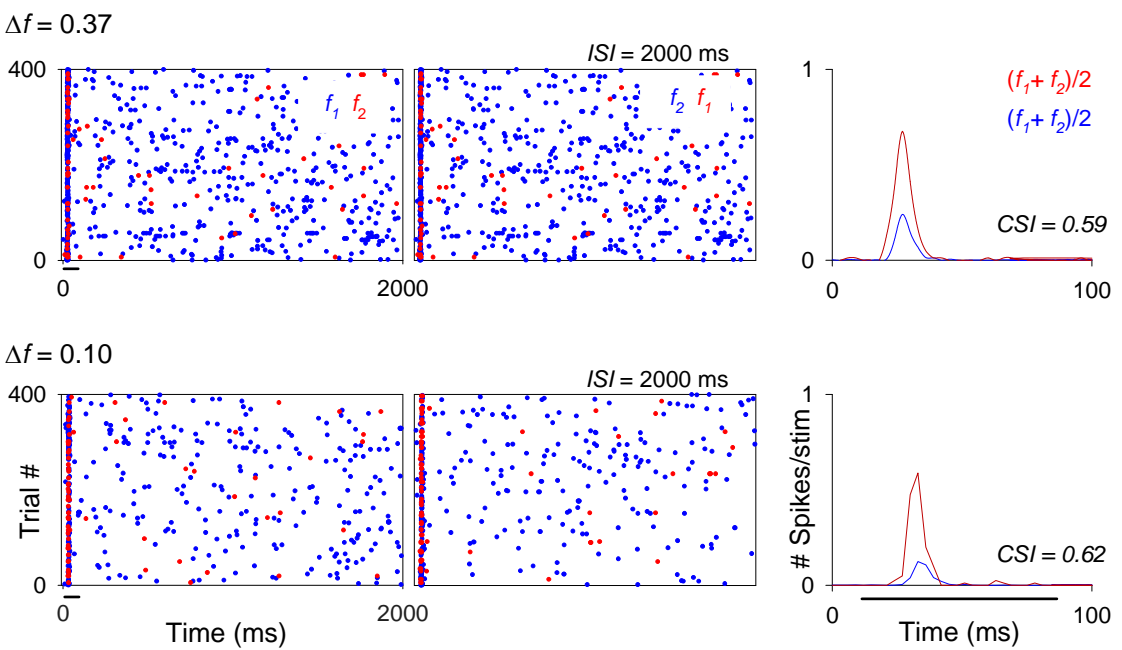

Figure 19. Example of an onset neuron with spontaneous activity recorded in the MGM, showing strong adaptation under all of the conditions tested. (a) the neuron exhibited extreme adaptation when tested at the same ISI $(500 \mathrm{~ms})$ for two different $\Delta \mathrm{fs}(0.37$ and 0.10 ; first and second rows, respectively). (b) the neuron showed somewhat lower adaptation when tested at the longest ISI (2000 ms; same $\Delta \mathrm{fs}$ as in a). In both a and b, the adaptation was similar for both $\Delta f$ conditions. Details of dot rasters and PSTHs are the same as in figure 14. The location of this neuron is shown in figure 17A. 


\section{Temporal dynamics of SSA in the MGB}

To study the temporal dynamics of SSA in the population of MGB neurons, I calculated the average population firing rate versus trial number, for the two ISI conditions that showed the highest levels of adaptation (ISI $=250$ and $500 \mathrm{~ms}$ ), and for which I collected the most data (Figure 20). I analyzed separately the non-adapting neurons $(\mathrm{CSI} \leq 0.18)$ and the adapting neurons $(\mathrm{CSI}>0.18)$ (Fig. 20a, b; left and right columns, respectively). This analysis demonstrated that in the initial trials, the average responses to the standard and deviant stimuli were similar (Fig. 20). The adapting neurons maintained or only slightly reduced their response to the deviant stimulus through the trials, while the response to the standard declined more strongly after the first few trials (Fig. 20; right column). The responses of non-adapting neurons to the standard also showed some decrement after the first trials, especially for the $\Delta \mathrm{f}=0.37$ conditions (Fig. 20; left column), but this decrement was much smaller than that of the adapting neurons. As a consequence, non-adapting neurons maintained a higher firing rate to the standard than the adapting neurons across the trials, for all conditions (Fig. 20). Then, I fitted the responses to the standard with an exponential decay regression model $[\mathrm{f}=$ $\left.a^{*} \exp \left(-b^{*} x\right)\right]$ and a polynomial inverse first order regression model $\left[f=y_{0}+(a / x)\right]$. The polynomial inverse first order model was the one that provided the best fit to the responses to the standard across trials, for all conditions. Indeed, a high proportion of the adaptation to the standard by the adapting neurons was explained by this model, for the majority of conditions (ISI $=250 \mathrm{~ms}: r^{2}=0.68$ and 0.64 , at $\Delta f=0.37$ and 0.10 , respectively; ISI $=500 \mathrm{~ms}: r^{2}=0.47$ at both $\Delta \mathrm{fs} ; p<0.001$ for all conditions; Fig. 20a and $b$, respectively; right column, first and second rows). For the smallest $\Delta f(0.04)$ the variance explained by the model was reduced $\left(r^{2}=0.24,0.20\right.$ at ISI $=250$ and $500 \mathrm{~ms}$, respectively; $p<0.001$ for both conditions; Fig. 20, right column, third row). 
a

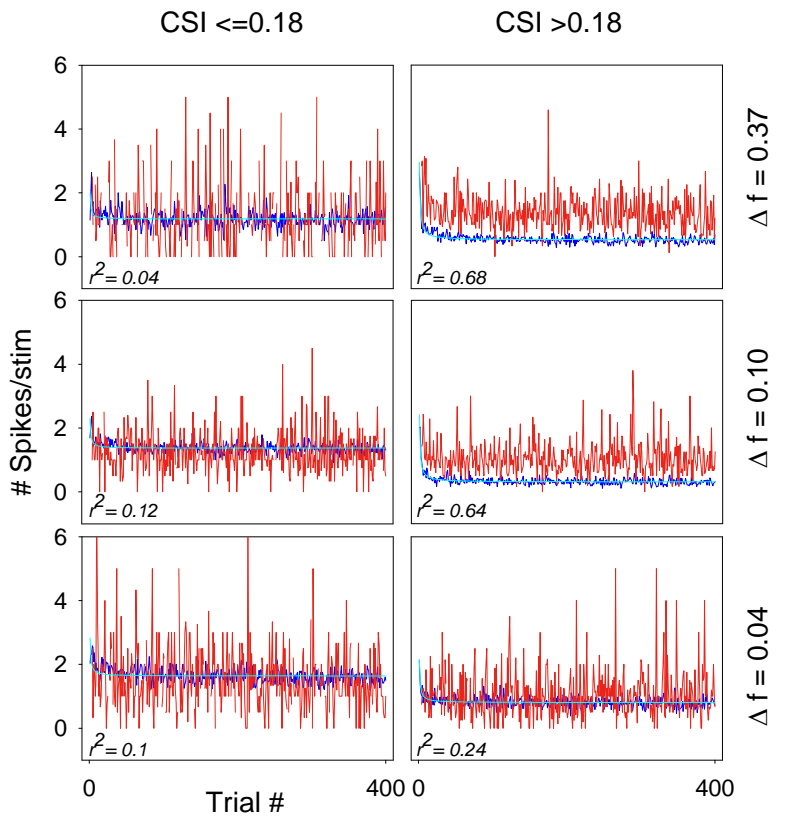

b

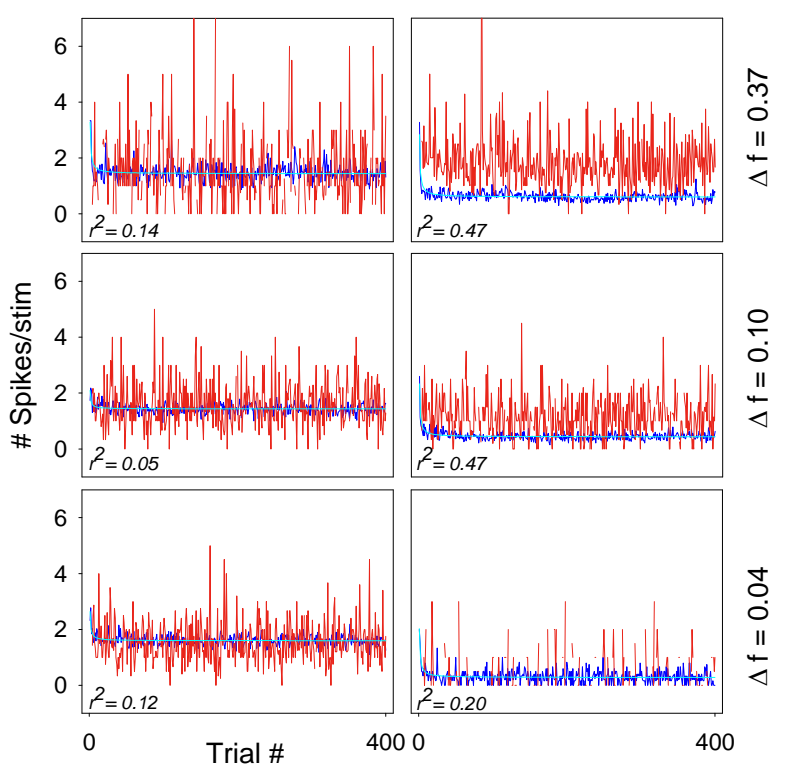

Figure 20. Time course of adaptation in the population of MGB neurons. Average population firing rate (spikes/stimulus) versus trial number for ISI $=250 \mathrm{~ms}$ (a) and ISI $=500 \mathrm{~ms}$ (b) and the different $\Delta \mathrm{fs}$ tested, indicated to the right of each row. In both a and $\mathrm{b}$, the left columns correspond to non-adapting neurons $(\mathrm{CSI} \leq 0.18)$ and right columns to adapting neurons $(\mathrm{CSI}>$ 0.18). The response of the adapting neurons to the standard stimulus strongly declined after the first trials. A high proportion of their adaptation to the stimulus was explained by a polynomial inverse regression model $\left[\mathrm{f}=\mathrm{y}_{0}+(\mathrm{a} / \mathrm{x})\right]$, for the majority of conditions; the amount of explained variance was reduced for the smallest $\Delta \mathrm{f}(0.04)\left(r^{2}=0.24,0.20\right.$ in a and $\mathrm{b}$, respectively; $p$ $<0.001$ for both conditions); and it was very low for the non-adapting neurons, at all conditions. 
For the non-adapting neurons, the variance explained by the model was very low for all conditions (ISI $=250 \mathrm{~ms}: r^{2}=0.04,0.12$ and 0.1 , for $\Delta \mathrm{f}=0.37,0.1$ and 0.04 , respectively; ISI $=500 \mathrm{~ms}: r^{2}=0.14,0.05$ and 0.12 , for $\Delta \mathrm{f}=0.37,0.1$ and 0.04 , respectively; $p<0.001$ for all conditions; Fig. 20, left column). The smaller amount of variance explained by the regression model in these conditions presumably reflects the minor amount of adaptation of the non-adapting neurons.

\section{SSA in relation to discharge patterns and latencies}

Before analyzing the relation between SSA and the response patterns of the MGB neurons that I recorded, I analyzed their general response pattern types to auditory stimuli, independently of their SSA degree. This analysis showed, that a high percentage of the neurons that I recorded had onset responses to auditory stimuli $(53 \%$; 49/93, e.g., Figs. 14, 18 and 19), while the second largest percentage had sustained responses $(24 \%$; 22/93, e.g., Fig. 16; defined as neurons that responded for $50 \mathrm{~ms}$ or more [Bordi and LeDoux, 1994a; Edeline et al., 1999], in response to a 75 ms stimulus). In addition, some neurons $(10 \% ; 9 / 93)$ had two different response components: a brief onset burst at a relatively short latency $(10-30 \mathrm{~ms})$ followed by a long-duration burst at a much longer latency $(>115 \mathrm{~ms})$. Both response components were tuned to the same frequency range, but were clearly segregated in time. Here, I refer to these units as onlate units. Fig. 21a shows an example of one of these units, recorded from the MGD and exhibiting SSA. A small percentage of neurons had offset responses $(8 \% ; 7 / 93)$. Figure $21 \mathrm{~b}$ shows an example of one of these units, recorded from the MGV, also exhibiting SSA. Finally, some units $(2 \% ; 2 / 93)$ had on-off responses. 
a On-long latency neuron

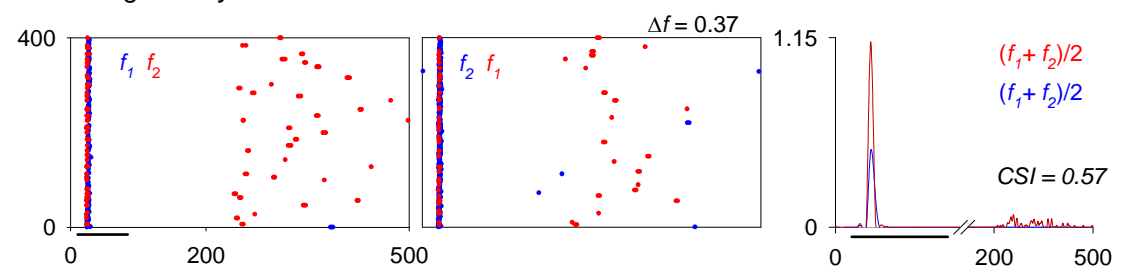

b Off neuron

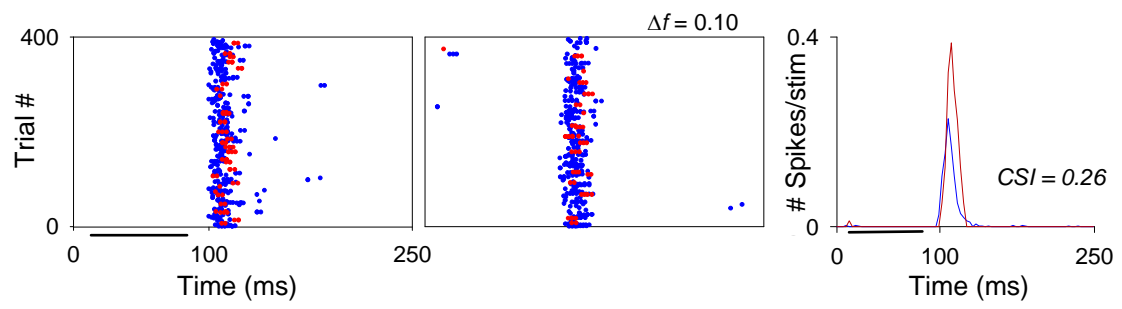

Figure 21. (a) Example of an on-late neuron in the MGD. This neuron responded with a brief onset burst at a relatively short latency $(14.8 \pm 0.4$ and $16 \pm 0.5 \mathrm{~ms}$; average of the mean firstspike latency for $\mathrm{f}_{1}$ and $\mathrm{f}_{2}$ when deviant and standard, respectively) followed by a long-duration burst at a much longer latency $\left(245.8 \pm 7 \mathrm{~ms}\right.$; average of the mean first-spike latency for $\mathrm{f}_{1}$ and $\mathrm{f}_{2}$ when deviant). The neuron showed some adaptation in the onset burst but much stronger adaptation in the late latency burst $(\mathrm{CSI}=0.31$ and 0.98 , respectively; $\mathrm{CSI}=0.57$ for the entire response time window). Details of dot rasters and PSTHs are the same as in figure 14. (b) Example of an offset neuron from the MGV that exhibits some adaptation $(\mathrm{CSI}=0.26)$. Details of dot rasters and PSTHs are the same as in figure 14.

Next, I quantified the percentage of neurons with and without SSA that are distributed over the response pattern types that I described in the previous analysis. This analysis showed that over half of the units $(56 \% ; 52 / 93)$ exhibited SSA for at least one of the two largest $\Delta \mathrm{fs}(0.37$ and 0.10$)$ at one of the intermediate ISIs (250 and $500 \mathrm{~ms})$. Of these units, the majority were onset responders $(73 \% ; 38 / 52)$, followed by on-late responders $(12 \% ; 6 / 52)$, and a minority of sustained, long latency and offset responders (6, 6 and 4\%; 3, 3 and 2/52, respectively). Of the neurons without SSA (44\%; 41/93), the majority were sustained responders $(44 \% ; 18 / 41)$, followed by onset responders $(24 \% ; 10 / 41)$, and by smaller percentages of offset, on-late, long latency and on-off responders $(12,7.3,7.3,5 \% ; 5,3,3,2 / 41$, respectively). The distributions of unit types among the neurons with and without SSA was significantly different $\left(\chi^{2}=22\right.$, d.f. $=2, p$ $<0.001)$. 
In order to analyze the relationship between SSA and response latencies, I plotted the mean first-spike latencies to the standard and deviant stimuli for all neurons under all conditions tested to determine whether their means differed (Fig. 22a). For the on-late neurons, I calculated separately the latency of their onset component $(<115 \mathrm{~ms})$ and the latency of their long latency component $(>115 \mathrm{~ms})$. For this reason, 16 out of the 388 data points in figure $22 \mathrm{~A}$ correspond to the long latency components of these neurons. The latency of the responses evoked by the deviant was significantly shorter on average than that evoked by the standard (42.9 and $45.7 \mathrm{~ms}$, respectively; paired ttest: $t=5.79$, d.f. $=387, p<0.001$ ). Figure 23 shows an example of a neuron that exhibited a much shorter latency to the deviant than to the standard stimulus. For this neuron, the mean first spike latency of the response to the deviant was on average 15.1 ms shorter than that to the standard stimulus for an ISI $=250(26 \pm 0.4$ and $41.1 \pm 1.6$ $\mathrm{ms}$; average of the mean first-spike latency for $\mathrm{f}_{1}$ and $\mathrm{f}_{2}$ when deviant and standard, respectively; Fig. 23); and 7.6 ms shorter for an ISI $=500 \mathrm{~ms}(24.7 \pm 1.1$ and $32.3 \pm 1.2$ $\mathrm{ms}$; average of the mean first-spike latency for $\mathrm{f}_{1}$ and $\mathrm{f}_{2}$ when deviant and standard, respectively; not shown). As would be expected, for this same neuron, the latency of the response to the first stimulus presentation of the set was similar for both stimuli $(24 \pm$ 0.7 and $23.5 \pm 0.3 \mathrm{~ms}$, average of the first-spike latency to the first stimulus presentation for all stimuli, at $\mathrm{SOA}=250$ and $500 \mathrm{~ms}$, respectively). 
a

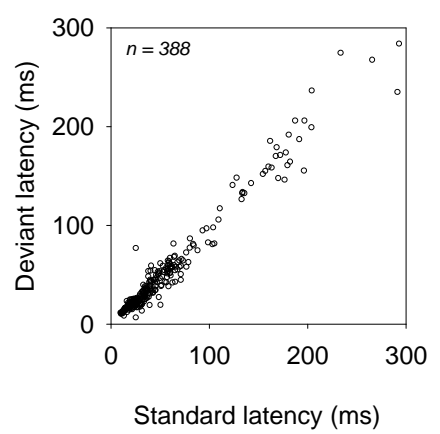

C

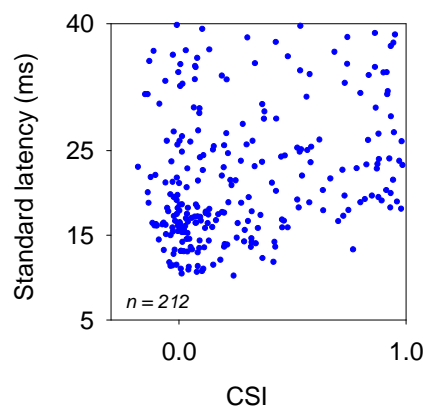

d

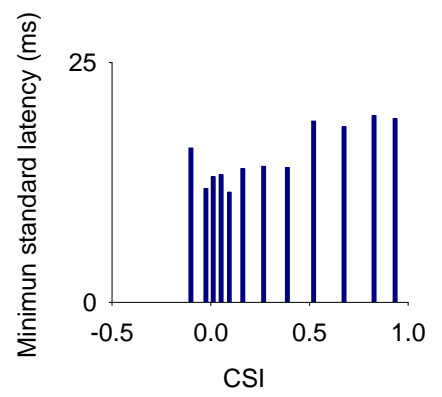

b
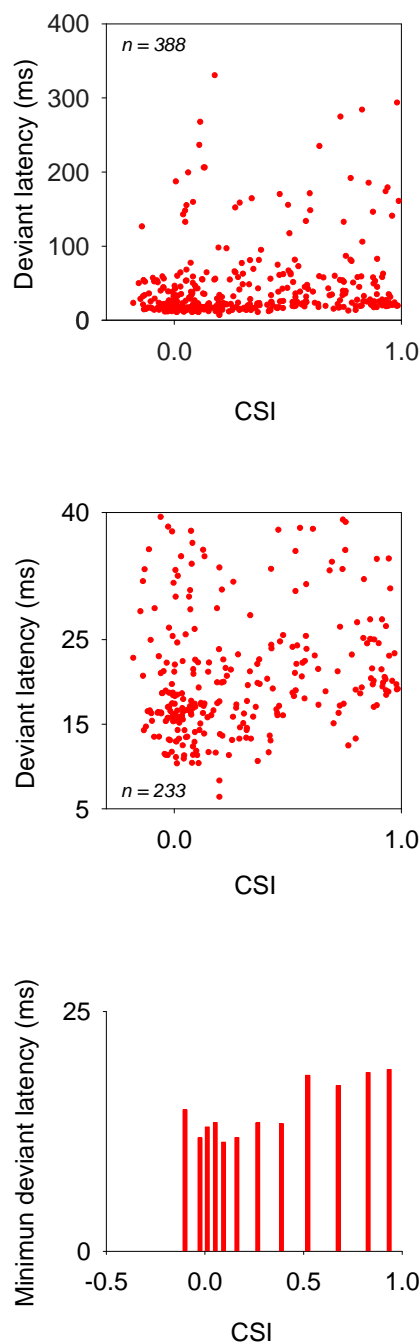

Figure 22. Response latencies in the MGB population of neurons. (a) Mean first-spike latencies to the deviant versus standard stimulus for the MGB population. Latencies to the deviant were on average significantly shorter than those to the standard stimulus (Mean $=42.9$ and $45.7 \mathrm{~ms}$, respectively; paired t-test: $t=5.79, n=388, d . f .=387, p<0.001$ ). (b) Mean first-spike latencies to the deviant versus CSI. The shortest latencies of highly adapting neurons were longer than those of non-adapting neurons. (c) Short-latency responses $(<40 \mathrm{~ms})$ to standard (left plot) and deviant (right plot) versus CSI. (d) The $10 \%$ percentile of the minimum latency distribution for the standard (left plot) and deviant (right plot) at different ranges of CSI. The minimal latencies of neurons with high CSI values $(>0.5)$ were longer than those with lower CSI values, except for the most negative CSI values. 

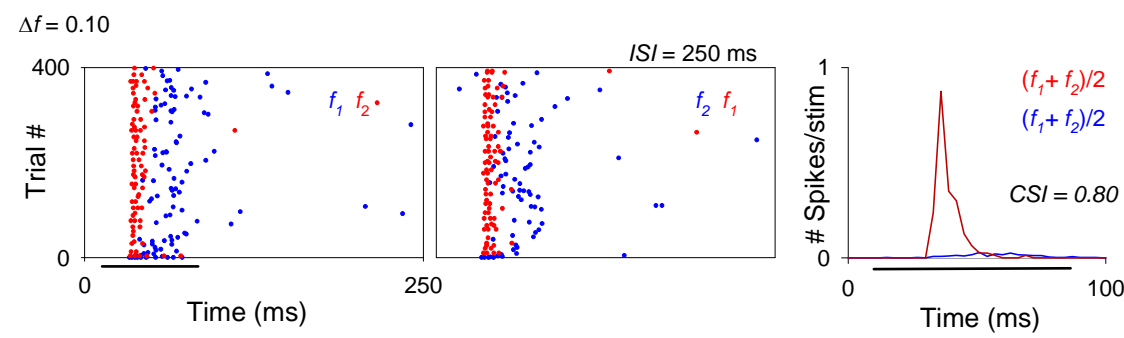

Figure 23. Example of an adapting neuron that responded with a much shorter latency to the deviant than to the standard stimulus $(26 \pm 0.4$ and $41.1 \pm 1.6 \mathrm{~ms}$; average of the mean firstspike latency between $f_{1}$ and $f_{2}$ when deviant and standard, respectively), for a $\Delta f=0.10$ at ISI $=$ $250 \mathrm{~ms}$ condition. The latency of the response to the first stimulus presentation of the set was similar for both stimuli, it was even slightly shorter to the standard $(24.5 \pm 0.7$ and $23.5 \pm$ $0.2 \mathrm{~ms}$, average of the first-spike latency to the first stimulus presentation between $\mathrm{f} 1$ and $\mathrm{f} 2$, when deviant and standard, respectively). Details of dot rasters and PSTHs are the same as in figure 14.

The latencies of the MGB neurons were distributed over a broad range (Fig. 22a); to determine whether the latency of the neurons was related to the amount of SSA that they exhibited, I plotted their mean first-spike latencies to the deviant versus their CSI (Fig. 22b). While most latencies were distributed similarly across all values of CSI (Fig. 22b), the shortest latencies of neurons with large CSIs tended to be somewhat longer than the shortest latencies of those neurons with small CSIs. To better visualize this issue, Fig. 22c displays only short-latency responses $(<40 \mathrm{~ms})$ to standards (left plot) and deviants (right plot) as a function of CSI. Although there was considerable overlap at all CSIs, the CSI did have a significant effect on the variation of the minimal latencies $(<25 \mathrm{~ms})$ for both standard and deviant stimuli [1-way ANOVA grouped by CSI: $F_{(11,171)}=3.64 ; p<0.001 ;$ and $F_{(11,203)}=4.72 ; p<0.001$, for deviant and standard respectively]. The minimal latencies of neurons exhibiting high CSI values $(>0.5)$ were longer than those exhibiting lower CSI values, except for the most negative CSI values (Fig. 22e displays the $10 \%$ percentile of the minimum latency distribution at different ranges of CSI; standard, left plot; deviant, right plot). 


\section{PART II: CORTICUFUGAL MODULATION OF STIMULUS-SPECIFIC}

\section{ADAPTATION IN THE MEDIAL GENICULATE BODY}

The results that I described in the previous chapter demonstrate that a significant percentage of neurons in the MGB adapt in a stimulus-specific manner. Here, I aimed to address if this property in the MGB is inherited from the $\mathrm{AC}$ via the corticofugal pathway. To test this hypothesis, I reversibly deactivated the AC using the cooling technique while recording the responses of 51 well isolated single units in the MGB. As controls, I recorded the responses of the same units, before and after AC deactivation (warm and recovery conditions; Fig. 24). Since the units recovered after AC rewarming, each unit served as its own control (e.g., Fig. 24-27). The few neurons that did not show full recovery after AC deactivation (3 out of 51) were excluded from the analysis. Here, for the oddball paradigm I used the combination of conditions that elicited the most SSA in the MGB neurons in the previous experiments $(\Delta \mathrm{f}=0.10, \mathrm{ISI}=$ $250 \mathrm{~ms}$ and $90 / 10 \%$ probability).

My main finding is that the neurons that exhibited SSA before AC deactivation (30 out of 48 neurons, warm condition; CSI $>0.18$ ) retained significant SSA levels during AC deactivation (cool condition; Figs. 25-27). However, other response properties of the MGB neurons that I tested simultaneously, changed significantly under AC deactivation, such as: spectral response patterns (see FRAs on Figs. 25 and 26); spontaneous activity (the units in Fig. 25, reduced their spontaneous activity; the unit in Fig. 26a-1, augmented its spontaneous activity); evoked firing rate (the units in Fig. 25 and 26m-x were suppressed; the unit in Fig. 26a-1 was facilitated; Fig. 28); and latency (Fig. 29). I will analyse in detail the changes in firing rate and latency, after describing the effects of AC deactivation on SSA. 

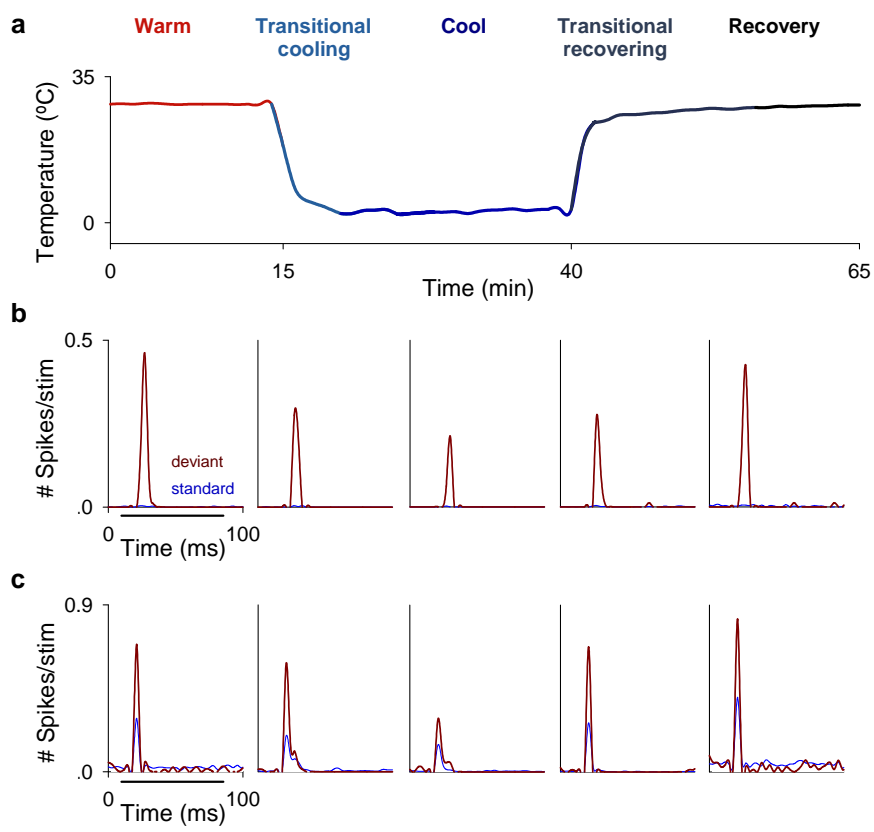

Figure 24. Stages of the AC deactivation cycle. (a) Temperature changes recorded at the cooling loop during a complete deactivation cycle. (b) PSTHs show the activity of the units that Fig. 25a-1 and (c) Fig. 25m-x show in the five stages of the cycle. Note the strong decrease in activity during the cool condition compared with the activity in the warm and recovery conditions, and the gradual changes during the transitional stages between conditions.

\section{Effect of AC deactivation on SSA in the MGB}

$\mathrm{AC}$ deactivation had a non-specific effect on the responses to the standard and to the deviant in the population of MGB neurons. As a result, neurons that showed SSA had a stronger response to the deviant than to the standard stimulus under all conditions (warm, cool and recovery) (Fig. 25 and 26a-1; similar CSI value in all conditions for all neurons); and neurons that did not show SSA maintained a similar response to both stimuli (Fig. 26m-x). In the whole population, there were no significant differences between the median CSI when the AC was active and when it was deactivated (median CSI: 0.31, both conditions; Wilcoxon signed rank test, between warm and cool conditions: $n=37, Z=-1.290, p=0.2$; Fig. 27a). Eleven neurons were not included in 
the previous analysis because it was not possible to determine their CSI value for the cooling condition: 7 of these neurons because they ceased firing during cooling; and 4 neurons because they were suppressed to one of the frequencies of the pair chosen in the warm condition and therefore had an undefined SI value for this frequency. There were no significant differences between the median CSI during warm and recovery conditions (median CSI: 0.27 and 0.25, respectively; Wilcoxon signed rank test between warm and recovery conditions: $n=48, Z=-1.313, p=0.191$; this analysis included the 7 neurons that ceased firing and the 4 neurons that were suppressed to one of the frequencies during cooling). The overall distribution of CSI values in the population of neurons that were active during $\mathrm{AC}$ deactivation to both frequencies $(n=37)$ was similar for the three conditions (Fig. 27a). As for the whole population $(n=48)$, there were no differences in the median CSI before and after cooling for this population of neurons that were active during cooling (median CSI: 0.31 and 0.24 , warm and recovery condition, respectively; Wilcoxon signed rank test, between warm and recover conditions: $n=37, Z=-1.139, p=0.258)$.

The population analysis cannot detect significant changes in the SSA level that may have occurred in the individual neurons, even if they retained significant SSA during AC deactivation. In order to detect such changes, I used the bootstrap method over 1000 randomisations to estimate the standard deviation $(S D)$ of the CSI value in the warm condition, for each neuron (Fig. 27b). Then, I analysed if the CSI values of each neuron in the cool and recovery conditions were significantly different from the CSI in the warm condition based on the estimated SD. This analysis demonstrated that there were no significant differences between the CSI values in the different conditions for the majority of neurons: The CSI values during cooling and recovery for 42 of the 48 neurons are within the $S D$ determined for the CSI value in the warm condition. Of 
the 5 remaining neurons, 3 had a CSI value for one of the conditions within $2 S D$ of the

CSI in the warm condition (units 1 and 30 for the cool condition; unit 24 for the recovery condition). Only 2 of these neurons had a significantly lower CSI value during the cool condition (outside $3 S D$ of the CSI in the warm condition; units 40 and 48 in the cool condition; asterisks on Fig. 27b; see unit 40 in Fig. 26a-1). Even though, these neurons retained SSA during $\mathrm{AC}$ deactivation $(\mathrm{CSI}=0.39$ and 0.68 , respectively).
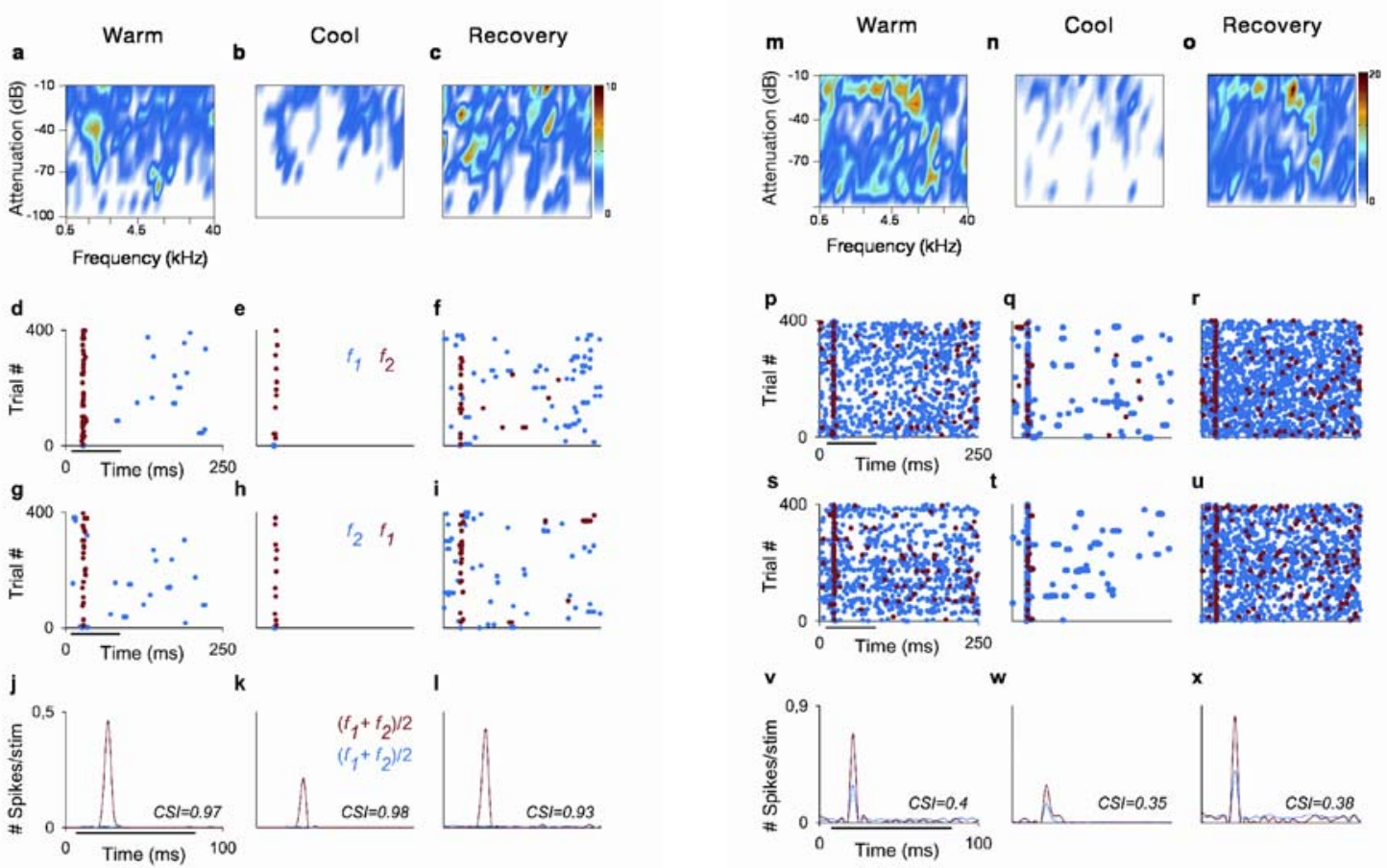

Figure 25. Examples of single unit responses in the MGB before, during and after AC deactivation. (a-c) The frequency response area (FRA) of a neuron localized to the medial subdivision (MGM) in the warm, cool and recovery conditions. (d-f) Responses of the neuron to the oddball paradigm as dot rasters, which plot individual spikes (red and blue dots, to the deviant and standard, respectively) in each of the three conditions, for the first block $\left(f_{1} / f_{2}\right.$ as standard/deviant) and (g-i) second block $\left(\mathrm{f}_{2} / \mathrm{f}_{1}\right.$ as standard/deviant) of stimulus presentations (stacked along the y-axis: trial \#, 400 trials each block). The time between trials $(250 \mathrm{~ms} ; \mathrm{x}-$ axis) corresponds to the stimulus repetition rate $(4 \mathrm{~Hz}$ rate; with $75 \mathrm{~ms}$ stimulus duration, black horizontal lines under the plots). (j-1) PSTHs show the number of spikes/stimulus (bin duration: $3 \mathrm{~ms})$ averaged over the two blocks [(f1+f2)/2; blue line is standard, red line is deviant]. The CSI calculated for each condition is noted as an insert on the PSTHs. (m-x) responses of another neuron localized to the dorsal subdivision (MGD), presented as in a-l. 

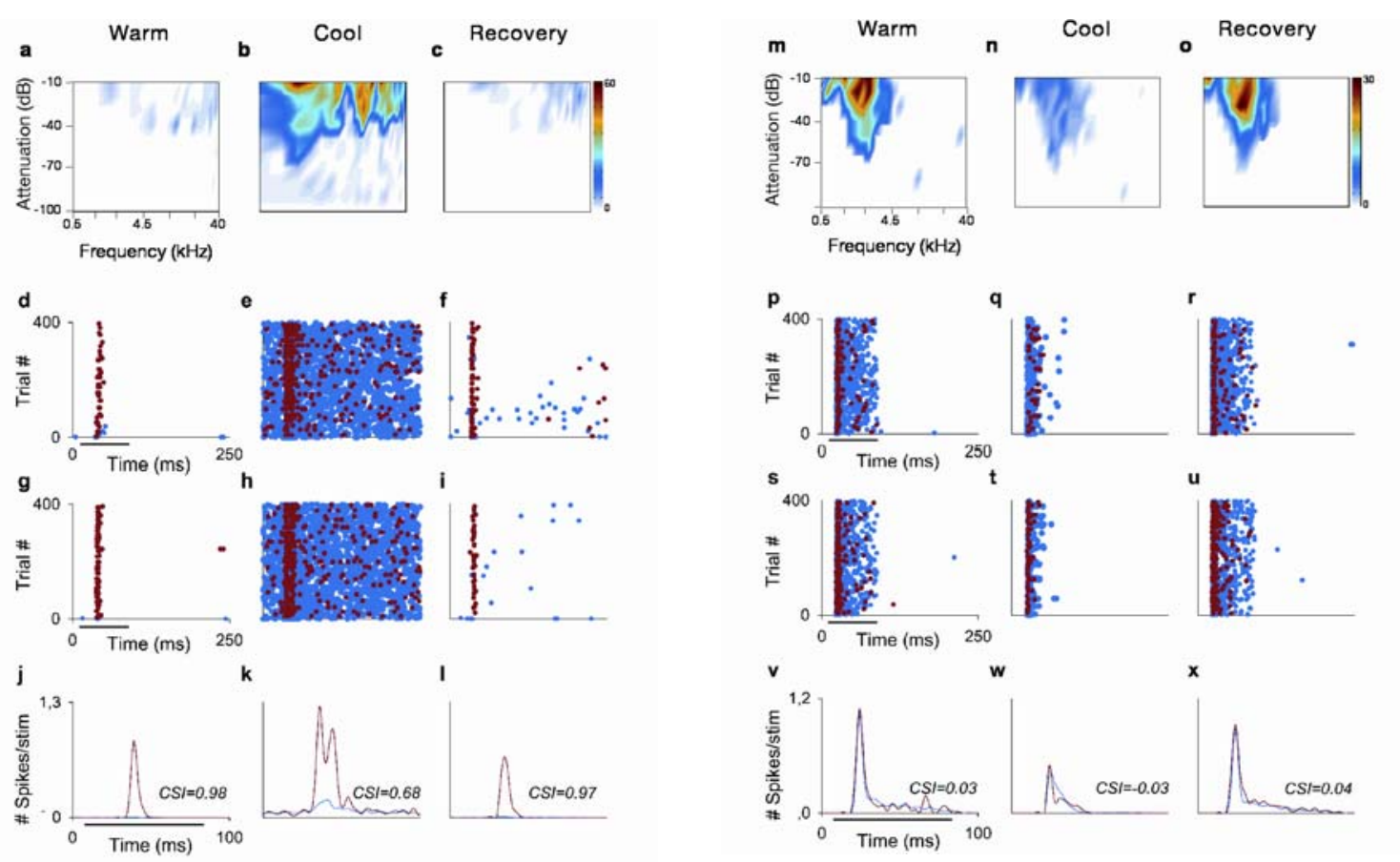

Figure 26. Examples of single unit responses in the MGB before, during and after AC deactivation. (a-c) The frequency response areas (FRA) in the three conditions of a neuron localized to the MGM that was facilitated during AC deactivation.(d-f) Responses of the neuron to the oddball paradigm as dot rasters, which plot individual spikes (red and blue dots, to the deviant and standard, respectively) in each of the three conditions, for the first block ( $\mathrm{fl} / \mathrm{f} 2$ as standard/deviant) and (g-i) second block (f2/f1 as standard/deviant) of stimulus presentations (stacked along the y-axis: trial \#, 400 trials each block). The time between trials ( $250 \mathrm{~ms}$; $\mathrm{x}-$ axis) corresponds to the stimulus repetition rate $(4 \mathrm{~Hz}$ rate; with $75 \mathrm{~ms}$ stimulus duration, black horizontal lines under the plots). (j-1) PSTHs show the number of spikes/stimulus (bin duration: $3 \mathrm{~ms})$ averaged over the two blocks [(f1+f2)/2; blue line is standard, red line is deviant]. The CSI calculated for each condition is noted as an insert on the PSTHs. (m-x) responses of another neuron localized to the ventral subdivision (MGV) with a V-shaped type FRA that did not show SSA (similar response to both stimuli: $\mathrm{CSI} \sim 0$ ).

\section{Effect of AC deactivation on the temporal dynamics of SSA}

I further studied the temporal dynamics of SSA in the different conditions, to address possible alterations in these dynamics with cortical deactivation. I calculated the average population firing rate in response to the standard stimulus across trials, before, during and after cortical deactivation (Fig. 27c, d). I analysed separately the responses of neurons with and without SSA to the standard stimulus $(\mathrm{CSI}>0.18$ and $\mathrm{CSI} \leq 0.18$, 
respectively; Fig. 27c, d) and found a similar temporal dynamics to that of the previous experiments in part 1 , for the same stimulation conditions (compare the responses in Fig. 27c and d, warm condition, with the responses to the standard in Fig. 20A, second row, right and left columns, respectively). Since the neurons did not adapt to the deviant stimulus, they maintained their response to this stimulus through the trials in each condition (Fig. 27e).

As expected, the responses to the standard of neurons with SSA declined strongly after the first few trials before AC deactivation (warm condition; Fig. 27c). These neurons reduced their firing rate during AC deactivation (cool, blue trace), which was recovered to the rate exhibited before deactivation (warm, red trace) after rewarming (recovery, yellow trace), but maintained similar dynamics of adaptation under all conditions (Fig. 27c). Indeed, the model that provided the best fit to these responses in the warm condition when the $\mathrm{AC}$ was active, explained a high proportion of the adaptation, and yielded similar results in the three conditions (Polynomial inverse model: $\mathrm{f}=\mathrm{y}_{0}+(\mathrm{a} / \mathrm{x})+\left(\mathrm{b} / \mathrm{x}^{2}\right) ; r^{2}=0.61,0.53,0.55$, warm, cool, and recovery, respectively; $p<0.0001$, all conditions). Hence, the neurons showing SSA maintained a similar adaptation dynamics when the $\mathrm{AC}$ was deactivated to that when it was active. This demonstrates that the AC exerts no significant effect on the SSA exhibited by the majority of MGB neurons and on its dynamics over time, and that SSA in this nucleus is not inherited from the AC. The AC would rather modulate the general response properties of MGB neurons in a gain control manner. Such modulation would affect in a similar way both stimuli and may explain the absence of an effect on the SSA exhibited in the MGB. 


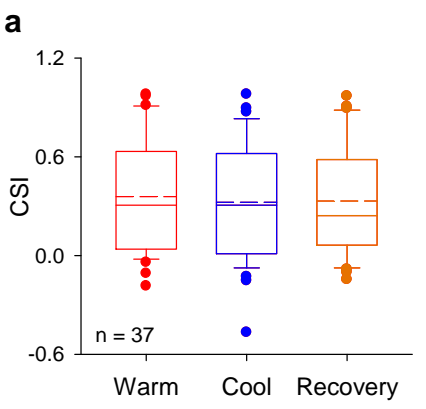

b
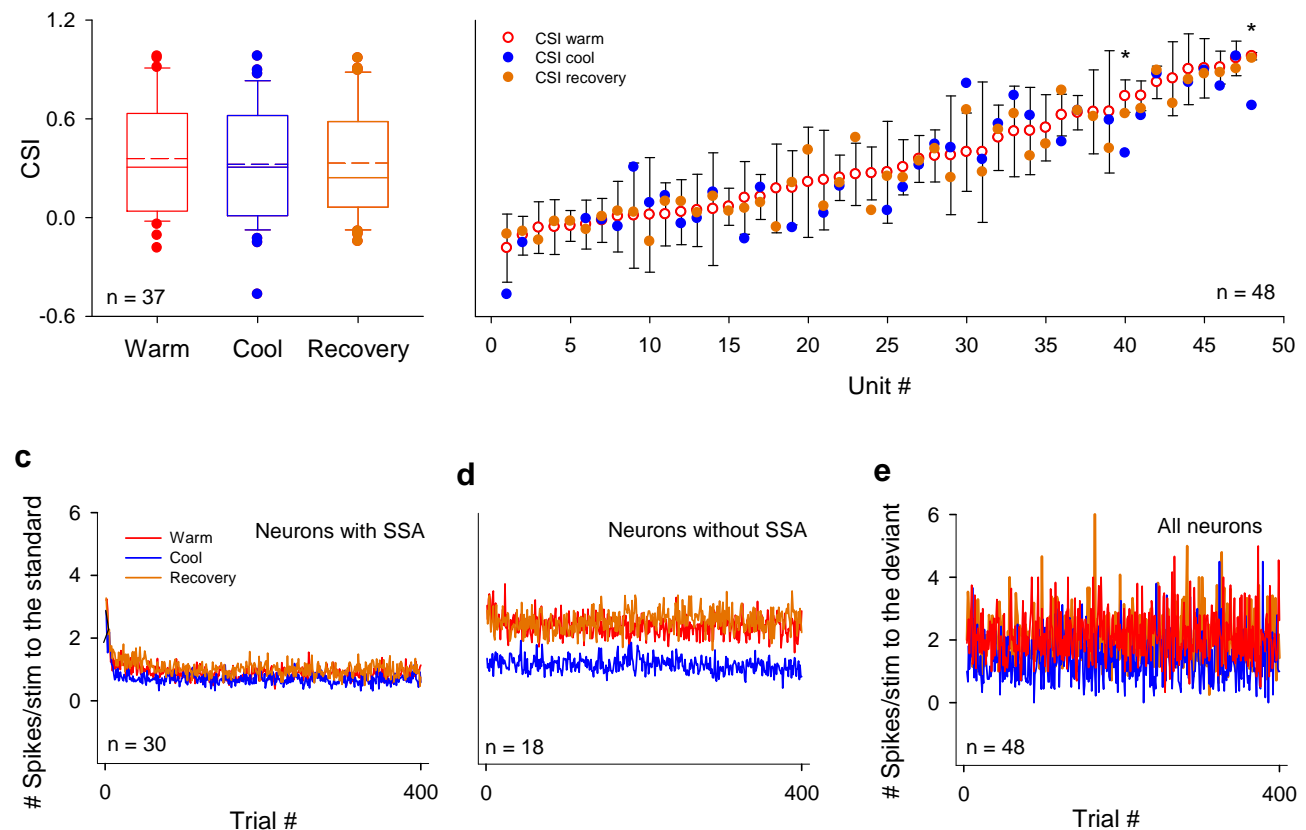

d
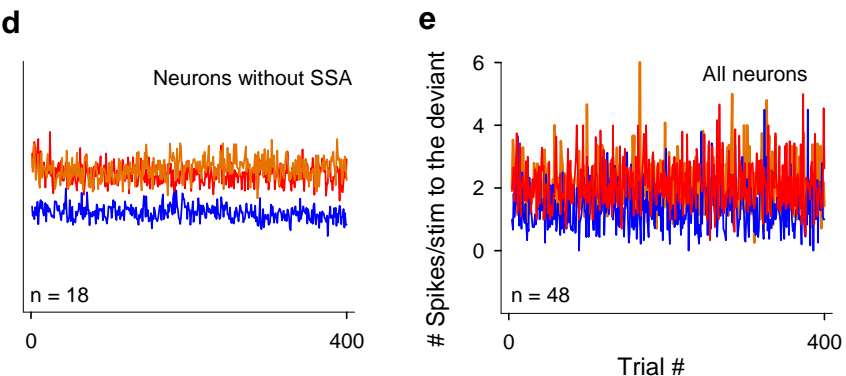

Figure 27. SSA quantification and its time course of adaptation in the MGB neurons before, during and after AC deactivation. (a) Box plots showing the distribution of CSI values in the warm (red), cool (blue) and recovery conditions (orange), for the population of active neurons that responded to both frequencies during cooling $(n=37)$. The continuous and dashed horizontal lines across the plots represent the median and mean values, respectively. (b) CSI values for each individual neuron in the warm (red dots), cool (blue dots) and recovery (orange dots) conditions. Of the 48 neurons only 37 had a CSI value for the cool condition. Error bars represent SD calculated using bootstrapping. Asterisks indicate neurons that had a CSI value in the cool condition outside $2 \mathrm{SD}$ of the bootstrapped sample. (c) Average population firing rate (spikes/stimulus) in response to the standard stimulus of the neurons with adaptation (CSI > $0.18)$ and $(\mathrm{d})$ without adaptation $(\mathrm{CSI} \leq 0.18)$ versus trial number, in the warm (red line), cool (blue line) and recovery (orange line) conditions. (e) Responses to the deviant stimulus for all neurons, presented as in c-d.

The neurons that did not exhibit SSA showed a minor decrement in their discharge rate after the first trials in the warm condition that was lost during $\mathrm{AC}$ deactivation (Fig. 27d; the variance explained by the same polynomial inverse model described above was close to zero in the warm condition: $r^{2}=0.09, p<0.001$; the model was not significant in cool and recovery conditions: $p=0.378$ and 0.516 , respectively). The overall firing rate to the standard of these neurons was strongly reduced with cortical deactivation in relation to the warm condition. This effect was less 
pronounced in the neurons that show SSA (compare Fig. 27c and d). This suggests that the $\mathrm{AC}$ exerts a differential modulatory effect on the discharge rate of neurons exhibiting different levels of SSA.

\section{Effect of $A C$ deactivation on the firing rate of $M G B$ neurons}

The average firing rate evoked by both stimuli in the whole population of MGB neurons was significantly lower while the AC was cooled and deactivated (only 9 out of 48 neurons augmented their firing rate; e.g. Fig. 26a-1) than while it was active $(n=48$; median firing rate to the deviant: 1.34 and 0.54 spikes/stimulus, warm and cool conditions, respectively; median firing rate to the standard: 0.85 and 0.16 spikes/stimulus, warm and cool conditions, respectively; Wilcoxon signed rank test, between the warm and cool conditions: $Z=-4.913$ and -4.667 , deviant and standard, respectively, $p<0.001$, both stimuli; Fig. 28a, c; e.g. Fig. 24, 25 and 26m-x). Neurons recovered their initial firing rate after $\mathrm{AC}$ rewarming $(n=48$; median firing rate to the deviant: 1.34 spikes/stimulus, both conditions; median firing rate to the standard: 0.85 and 0.67 spikes/stimulus, warm and recovery conditions, respectively; Wilcoxon signed rank test, between the warm and recovery conditions: $Z=-0.369$ and $-0.944, p=0.716$ and 0.348, deviant and standard, respectively; Fig. 28b, c; e.g. Fig 24-26).

The reduction in firing rate was significant in both populations, but it was stronger in the population of neurons without SSA $(n=18$; median firing rate to the deviant: 1.5 and 0.43 spikes/stimulus, warm and cool conditions, respectively; median firing rate to the standard: 1.56 and 0.52 spikes/stimulus, warm and cool conditions, respectively; Wilcoxon signed rank test, between the warm and cool conditions: $Z=$ 3.72, $p<0.001$, both stimuli), than on the population of neurons with SSA $(n=30$; 
median firing rate to the deviant: 1.16 and 0.54 spikes/stimulus, warm and cool conditions, respectively; median firing rate to the standard: 0.4 and 0.14 spikes/stimulus, warm and cool conditions, respectively; Wilcoxon signed rank test, between the warm and cool conditions: $Z=-3.22$ and -2.56 , deviant and standard, respectively, $p<0.01$, both stimuli).

Next, I analysed the effect of AC deactivation on the discharge rate of neurons across the different SSA levels. To do so, I plotted the CSI versus the difference in firing rate between the warm and cool conditions for each neuron (Fig. 28d, e; standard and deviant, respectively): positive values for this difference indicate a reduction in firing rate with $\mathrm{AC}$ deactivation; and negative values an increment (Fig. 28d, e; values above and below the horizontal line at the origin, respectively). This difference in firing rate was inversely correlated with CSI for both stimuli (Pearson: $r=-0.645$ and -0.496 , standard and deviant, respectively; $p<0.001, n=48$, both stimuli; Fig. 28d, e). The correlation coefficient is higher for the standard than for the deviant stimulus, but this difference is not significant since the slopes of the standard and deviant regression lines are not significantly different from each other (ANCOVA: $F_{(1,92)}=1.89, p=0.172$, main effect of stimuli; $F_{(1,92)}=43.27, p=0$, main effect of CSI; and $F_{(1,92)}=0.23, p=$ 0.634, interaction; $n=48$; Fig. 28d, e). Neurons without SSA were suppressed during AC deactivation to both stimuli (Fig. 28d, e; CSI values around zero, vertical dashed line); then, as the CSI of the neurons increased, i.e., showed greater SSA, they became less suppressed (Fig. 28d, e; standard and deviant, respectively). Furthermore, some highly adapting neurons were facilitated during AC deactivation to both stimuli (Fig. 28d, e; e.g. unit on Fig. 26a-1). This suggests that the AC has a differentially effect upon the discharge pattern of neurons exhibiting different levels of SSA; neurons without SSA are mainly facilitated, but some neurons with high SSA are suppressed by the AC. 
a

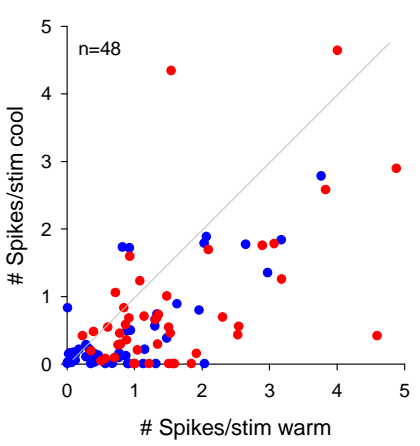

b

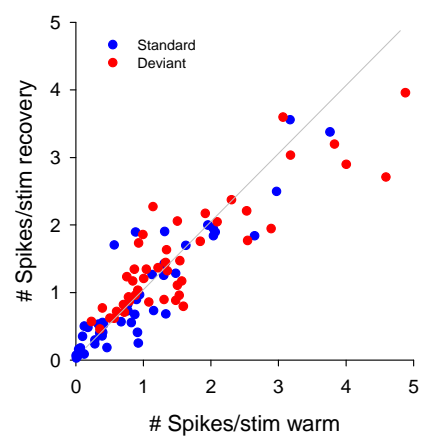

C

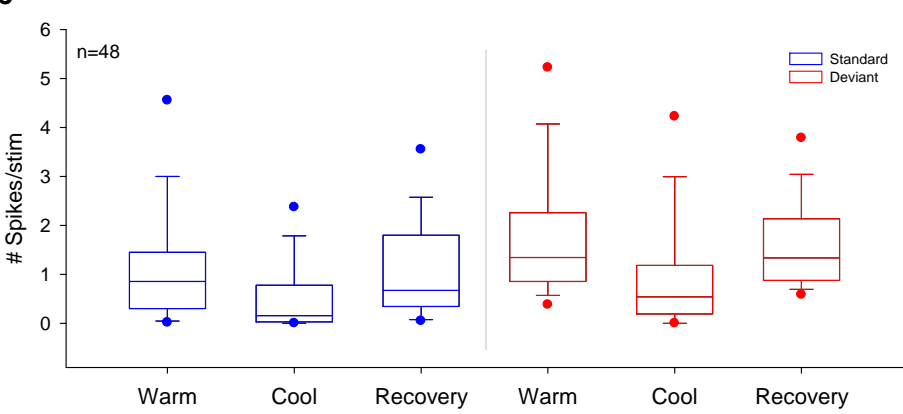

d
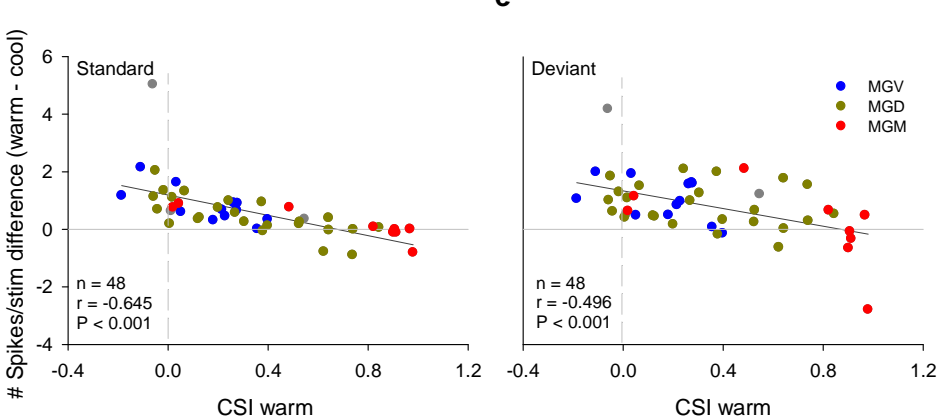

Figure 28. Effect of AC deactivation on the firing rate of MGB neurons. (a) Scatterplots of the responses of all neurons (spikes/stimulus, $n=48$ ) to the deviant (red dots) and standard stimulus (blue dots) in the warm versus cool condition $(p<0.001$, both stimuli, Wilcoxon signed rank test), and (b) warm versus recovery condition (n.s., both stimuli, Wilcoxon signed rank test). (c) Box plots showing the distribution of firing rate values in the whole population $(n=48)$ in the warm, cool and recovery conditions, in response to the standard (blue plots) and the deviant stimulus (red plots). (d) Scatterplots of the CSI (warm condition) versus the difference in firing rate between the warm and cool conditions (spikes/stimulus difference) in response to the standard, and (e) in response to the deviant stimulus, for each neuron. Blue, green and red dots represent the neurons that were localized to the ventral $(n=12)$, dorsal $(n=24)$ and medial $(n=$ 9) subdivisions of the MGB, respectively $(n=45)$. Positive values indicate a reduction in firing rate with $\mathrm{AC}$ deactivation; and negative values an increment (above and bellow the horizontal line at the origin, respectively). 
I localized histologically 45 (out of 48 ) neurons to one of the three main MGB subdivisions: 24 neurons were localized to the MGD, 12 to the MGV and 9 to the MGM (Fig. 28d, e; green, blue and red dots, respectively; e.g. Figs. 25a-1 and 26a-1, units from the MGM; Fig. 25m-x, unit from the MGD; and Fig. 26m-x, unit from the MGV). Similarly to the previous experiments on chapter 1 SSA was stronger in the medial subdivision; intermediate in the dorsal and weakest in the ventral subdivisions (Mean CSI $0.65,0.36$ and 0.1 , respectively). This sample is biased towards the non-lemniscal subdivisions (total of 33 units from the MGD and MGM) where SSA is stronger and neurons show predominantly non-V shaped type FRAS. Although there was a significant effect of $\mathrm{AC}$ deactivation on the firing rate of this population, there was no effect of subdivision nor an interaction between condition and subdivision ( $n=45$; Two way repeated measures ANOVA, for the responses to the deviants: $F_{(1,42)}=21.95, p<$ 0.001 , main effect of condition; $F_{(2,42)}=2.96, P=0.06$, main effect of subdivision; and $F_{(2,42)}=0.12, p=0.89$, interaction; Two way repeated measures ANOVA, for the responses to the standards: $F_{(1.42)}=22.88, p<0.001$, main effect of condition; $F_{(2,42)}=$ $2.89, p=0.07$, main effect of subdivision; and $F_{(2,42)}=1.06, p=0.36$, interaction). The fact that the MGD shows a range of firing rate changes that extends through the CSI range is consistent with the ANOVA results. Furthermore, the MGM has also some neurons that were facilitated whereas others were suppressed. This lack of a correlation between subdivisions and the firing rate changes suggests that the degree of SSA exhibited by the MGB neurons determines the modulatory effect exerted by the AC on their discharge rate rather than their localization within subdivisions. 


\section{Effect of AC deactivation on the latency of MGB neurons}

To analyse the effect of AC deactivation in the latencies of the MGB neurons I calculated the mean first-spike latencies in response to each stimuli for the active neurons during $\mathrm{AC}$ deactivation $(n=41$; this analysis included the 4 neurons that were suppressed to one of the frequencies during cooling since they were active and responded to the other frequency). The population of active neurons during AC deactivation showed a significantly longer median latency during deactivation than before, in response to both stimuli ( $n=41$; median latencies to the deviant: 17.1 and $19.5 \mathrm{~ms}$, warm and cool condition, respectively; median latency to the standard: $17.5 \mathrm{~ms}$ and $21.3 \mathrm{~ms}$, warm and cool condition, respectively; Wilcoxon signed rank test, between warm and cool conditions: $Z=3.764$ and 4.244, deviant and standard, respectively; $p<0.001$, both stimuli; Fig. 29a, c). This lengthening of latency caused by $\mathrm{AC}$ deactivation indicates that the AC modulates the latency of the MGB neurons, shortening their latencies to both stimuli. The neurons recovered their latencies after AC deactivation: no differences were found between their initial latencies and those after AC rewarming and reactivation $(n=48$; median latencies to the deviant: 17.4 and 18.5 ms, warm and recovery condition, respectively; median latencies to the standard: 19.3 and $19.7 \mathrm{~ms}$, warm and recovery condition, respectively; Wilcoxon signed rank test, between warm and recovery conditions: $Z=0.697$ and $Z=0, p=0.489$ and $p=0.996$, deviant and standard, respectively; this analysis included the neurons that were inactive during cooling; Fig. 29b, d). 

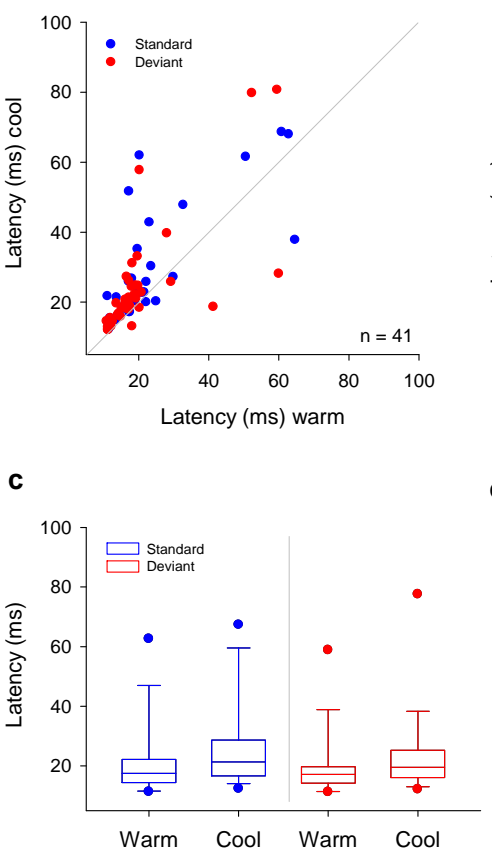

e

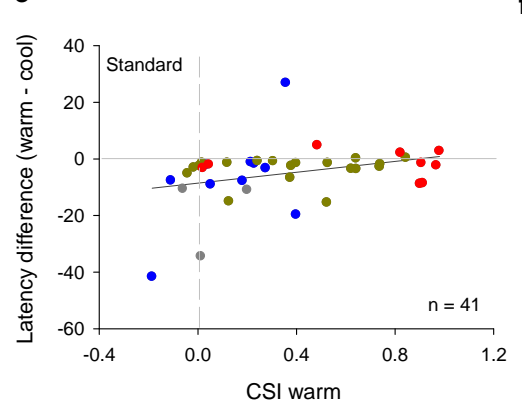

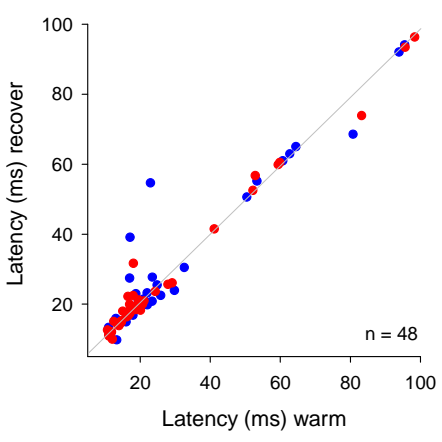

d
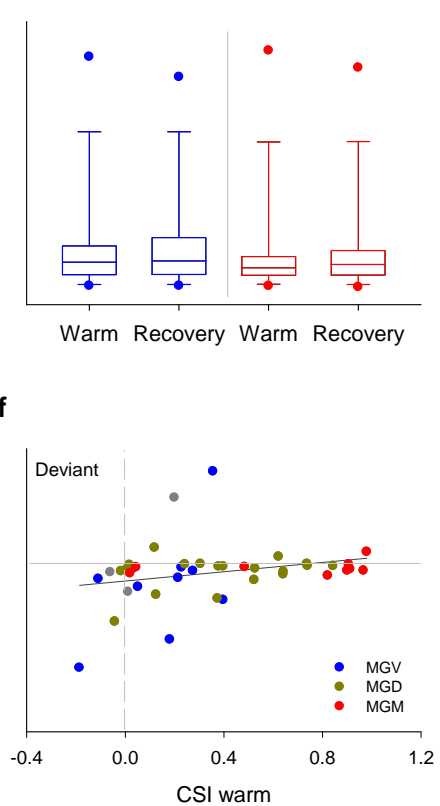

Figure 29. Effect of AC deactivation on the latency of MGB neurons. (a) Scatterplots showing the mean first spike latencies (latency, ms) of the active neurons during cooling $(n=41)$ to the deviant (red dots) and standard stimulus (blue dots) in the warm versus cool condition $(P<$ 0.001 , both stimuli, Wilcoxon signed rank test), and (b) the latencies of all neurons $(n=48)$ in the warm versus recovery conditions (n.s., both stimuli, Wilcoxon signed rank test). (c) Box plots showing the distribution of latency values in response to the standard (blue plots) and the deviant stimulus (red plots) in the warm and cool conditions for the population of active neurons during cooling $(n=41)$, and (d) in the warm and recovery conditions for all neurons $(n=48)$. (e) Scatterplots of the CSI (warm condition) versus the difference in latency between the warm and cool conditions (latency difference) in response to the standard, and (f) in response to the deviant stimulus, for each neuron. Blue, green and red dots represent the neurons that were localized to the ventral $(n=12)$, dorsal $(n=24)$ and medial $(n=9)$ subdivisions of the MGB, respectively $(n=45)$. Positive values indicate a decrease in latency with AC deactivation; and negative values an increase (above and bellow the horizontal line at the origin, respectively). 
As expected from the previous experiments on part 1, the latency of the responses to the deviant was significantly shorter than that to the standard, before AC deactivation (Median latency: 17.1 and $17.5 \mathrm{~ms}$, respectively; Wilcoxon signed rank test: $n=41, Z=4.879, p<0.001$; Fig. 29c, compare with Fig. 22a). This latency difference between the standard and the deviant was maintained during $\mathrm{AC}$ deactivation (Median latency: 19.5 and $21.3 \mathrm{~ms}$, deviant and standard, respectively; Wilcoxon signed rank test: $n=41, Z=2.041, p=0.04$; Fig. 29c).This indicates that the AC is not generating the latency gap in the responses to the standard versus the deviant exhibited by the MGB neurons.

In order to evaluate if the $\mathrm{AC}$ deactivation had a differential effect on the latency of the neurons across SSA levels, I plotted the CSI of the neurons versus the difference in the mean first-spike latency between the warm and cool conditions (Fig. 29e, f; standard and deviant, respectively; $n=41$, active neurons during cooling): negative values indicate a lengthening in the latency during $\mathrm{AC}$ deactivation; and positive values a shortening (Fig. 29e, f; below and above the horizontal line at the origin, respectively). This difference in latency was significantly and positively correlated with CSI, for the responses to the standard stimulus (Pearson: $r=0.319, p=0.042$; Fig. 29e). The latency of the responses to the deviant stimulus showed the same trend, but the correlation was not significant (Pearson: $r=0.262, p=0.099$; Fig. 29f). The slopes of the standard and deviant regression lines are not significantly different from each other indicating that there is no significant difference between the correlation coefficient obtained for both stimuli (ANCOVA: $F_{(1,78)}=0.34, p=0.561$, main effect of stimuli; $F_{(1,78)}=7.14, p=0.009$, main effect of CSI; and $F_{(1,78)}=0.05, p=0.829$, interaction; $n$ $=41$; Fig. $29 \mathrm{e}, \mathrm{f})$. This analysis showed that all neurons not showing $\mathrm{SSA}(\mathrm{CSI} \leq 0.18)$ had a longer latency during AC deactivation to both stimuli (Fig. 29e, f; Wilcoxon 
signed rank test, between warm and cool conditions: $n=15, \mathrm{Z}=2.95$ and $\mathrm{Z}=3.408, p=$ 0.002 and $p<0.001$, deviant and standard, respectively). By contrast, the few neurons that had a shorter latency during AC deactivation, showed some level of adaptation (CSI > 0.18; Fig. 29e, f; dots above the horizontal line); but still, the median latency of the population of neurons with SSA was significantly longer during AC deactivation to both stimuli (Wilcoxon signed rank test, between control and cooling, CSI > 0.18: $n=$ 26, $\mathrm{Z}=2.451$ and $\mathrm{Z}=2.578, p=0.015$ and $p=0.01$, deviant and standard, respectively). The higher warm-cool differences were exhibited by neurons with zero or intermediate CSI values (<0.45) from the MGV subdivision (Fig. 29e, f; blue dots). This indicates that the MGV is the subdivision in which latency depends strongest on modulation from the AC.

To look for significant effects and interactions between conditions, latencies and MGB subdivisions, I performed a two-way repeated measure ANOVA for the responses to each stimulus. Although there was a significant effect of $\mathrm{AC}$ deactivation on the latencies in the population of the neurons that were localized, there was no effect of subdivision nor an interaction between condition and subdivision (for the responses to the deviant: $F_{(1,36)}=4.520, p=0.04$, main effect of condition; $F_{(2,36)}=2.103, p=0.137$, main effect of subdivision; and $F_{(2,36)}=0.821, p=0.448$, interaction; for the responses to the standard: $F_{(1,36)}=6.788, p=0.013$, main effect of condition; $F_{(2,36)}=1.732, p=$ 0.191 , main effect of subdivision; and $F_{(2,36)}=0.64, p=0.533$, interaction). 
DISCUSSION 
In my $\mathrm{PhD}$ research I characterized SSA in the three main subdivisions of the MGB of rat under several conditions hitherto unexplored. I recorded from single neurons throughout the MGB, while stimulating the animals with a sequence composed of a rare tone presented in the context of a common tone, i.e., in an oddball paradigm. My results demonstrate that a significant percentage of neurons in the MGB adapt in a stimulus-specific manner. Neurons in the MGM exhibited the strongest SSA followed by neurons in the MGD. On the other hand, SSA was absent in the MGV under most of the tested conditions, and was found there only for the shortest ISIs used here (125-250 $\mathrm{ms}$, onset-to-onset). The stimulation conditions that evoked the strongest SSA in MGB neurons were the two largest $\Delta \mathrm{fs}(0.37,0.10)$ at the intermediate ISIs $(250$ and $500 \mathrm{~ms})$. Under these conditions a high percentage of MGM and MGD neurons showed strong to extreme adaptation. Moreover, some neurons in these subdivisions showed SSA even when tested with the longest ISI $(2000 \mathrm{~ms})$ as well as the smallest $\Delta \mathrm{f}(0.04)$.

Thus, SSA is prominent in the non-lemniscal subdivisions of the auditory thalamus, but weak in the ventral, lemniscal, subdivision. To the best of my knowledge, this is the first account demonstrating levels of SSA in the non-lemniscal MGB up to those found previously in A1 (Ulanovsky et al., 2003), IC (Malmierca et al., 2009; Zhao et al., 2011) and TRN neurons (Yu et al., 2009), for comparable conditions. Hence, the auditory thalamus has substantial SSA and strongly represents frequency change detection. My results together with those of others (Anderson et al., 2009; Malmierca et al., 2009; Reches and Gutfreund, 2008; Ulanovsky et al., 2003; von der Behrens et al., 2009; Yu et al., 2009; Zhao et al., 2011) demonstrate the ubiquity of SSA in neurons throughout the auditory system, from the midbrain up to the auditory cortex.

Subsequently, in my thesis research I tested the hypothesis that SSA in thalamic neurons is inherited from the AC via corticofugal projections. To do that, I recorded the 
responses of single neurons throughout the MGB, before, during and after reversibly deactivating the AC by cooling (Lomber, 1999; Lomber et al., 1999; Ryugo and Weinberger, 1976; Villa et al., 1991) while stimulating the animals with the oddball paradigm and the stimulation conditions that elicited the most SSA in the previous experiments (ISI $=250 \mathrm{~ms}$, onset-to-onset; $\Delta \mathrm{f}=0.10$; for the $90 / 10 \%$ probability). Herein I report that SSA in MGB remains intact when the AC is deactivated by cooling. This demonstrates that the AC is not necessary for the generation of SSA in this thalamic nucleus. The AC does, however, modulate the responses of thalamic neurons in a gain control fashion.

Since no previous studies demonstrated the cortical independence of SSA in a subcortical auditory nucleus, I believe that my results will have an impact in the direction of future studies about the origin of SSA in the auditory system, and probably about its functional mechanisms.

\section{SSA in the MGB: comparison with previous studies}

Although two recent studies tested SSA in the MGB (Anderson et al., 2009; Yu et al., 2009), the contribution of this nucleus and each of its main subdivisions to SSA was until now poorly characterized. Yu and colleagues (2009) studied SSA in the rat MGB and thalamic reticular nucleus, a subdivision of the thalamus that lies outside the MGB. They demonstrated strong SSA in the thalamic reticular nucleus and weaker SSA in MGB. Anderson and colleagues (Anderson et al., 2009) reported SSA in mouse MGB, but tested fewer conditions and showed weaker SSA than reported in the current study. Herein, I demonstrated that some neurons in the rat MGB exhibit very strong SSA even under the most extreme conditions tested (ISIs $=2000 \mathrm{~ms}$ or $\Delta \mathrm{f}=0.04$ ). In 
fact, we found a few neurons in MGB with CSI values as high as those reported by $\mathrm{Yu}$ and colleagues (2009) in the thalamic reticular nucleus, even when using ISIs twice as long.

SSA in the rat MGB was evoked by similar stimulation conditions to those previously demonstrated to evoke SSA in cat AC (Ulanovsky et al., 2003) and rat IC (Malmierca et al., 2009). I cannot compare the IC with the MGB for the largest ISI since the IC study tested SSA in the rat IC only for relatively short ISIs (up to $500 \mathrm{~ms}$; Malmierca et al., 2009). However, a recent study demonstrated strong SSA in the IC for an ISI = $1000 \mathrm{~ms}$ (onset-to-onset, $54 \mathrm{~ms}$ stimulus duration; Zhao et al., 2011); which is consistent with preliminary data from our lab that demonstrates strong SSA in the IC for a larger ISI (2000 ms) as well (Malmierca et al., 2010). My results from the MGB (ISI $=2000 \mathrm{~ms}$, inter-tone duration $>1900 \mathrm{~ms}$ ) can be compared with those from the cat AC study (ISI $=2000 \mathrm{~ms}$, inter-tone duration $>1700 \mathrm{~ms}$ ). An ISI of $2000 \mathrm{~ms}$ corresponds to the most extreme condition for which Ulanovsky and colleagues (2003) showed single units exhibiting SSA in A1 (CSI 0.3). I found higher values of SSA for this condition in the MGB (up to CSI $=0.7$ ) than the previous study in the AC, but only outside the MGV. The MGV receives input from the central nucleus of the IC and is the main source of ascending input to A1 (He, 2003a; He, 2003b; Lee and Winer, 2005b; Lee and Winer, 2008a; Lee and Winer, 2008b). In this context, it is worth mentioning that SSA found in the central nucleus of the IC (Malmierca et al., 2009) is only relatively large for the shortest ISI tested $(125 \mathrm{~ms})$. Thus, the MGB and IC data tightly links SSA in subcortical regions to the non-lemniscal pathway (Malmierca et al., 2009; Perez-Gonzalez et al., 2005).

In the lemniscal pathway, CSI values reported in A1 of the cat are far in excess of the values that I found in the rat MGV, which are comparable to those measured by 
Ulanovsky and colleagues (2003) in cat MGB, presumably in the MGV. Thus, our results suggest that A1 is the first lemniscal station in which SSA is widespread and strong. SSA in A1 may therefore express the combined result of the rather weak SSA found in MGV augmented by intracortical mechanisms (Szymanski et al., 2009) and possibly by the weaker (but still present) non-lemniscal input to A1, either directly from the MGM (Kimura et al., 2003) or indirectly through feedback connections from higher auditory areas. For example, a recent study (Carrasco and Lomber, 2009a) has demonstrated that reversible thermal deactivation of AAF alters A1 responses but AAF responses are not altered by A1 deactivation. These authors suggest a unidirectional flow of information from the non-lemniscal to the lemniscal pathway. If so, the SSA observed in A1 may be modulated and enhanced by the influence of AAF (Ulanovsky et al., 2003). Another possibility is that SSA may be transferred through corticothalamocortical projections that allow interconnections between the nonlemniscal and the lemniscal auditory nuclei (Bajo et al., 1995; Llano and Sherman, 2008; Winer et al., 1999; Winer et al., 2001). Since SSA in the MGB is not inherited from the AC, there is still the possibility of a bottom-up generation of SSA from the MGB to the AC, mainly in the non-lemniscal pathway. If so, SSA from the nonlemniscal thalamus arriving to the cortex can be enhanced and modulated at the cortical level and further transmitted to A1 through the mechanisms that I aforementioned.

High SSA neurons in both the MGB and the IC (Malmierca et al., 2009; PerezGonzalez et al., 2005) were mainly onset responders, with relatively short latencies $(<40$ ms) for both the standard and the deviant stimuli. Nevertheless, the shortest latencies of the neurons that showed strong SSA for a certain condition in the MGB were significantly longer than those of weakly adapting neurons for a certain condition, to both the deviant and standard stimuli. The same phenomenon occurs in the rat IC 
(Malmierca et al., 2009), and raised the question of whether these slightly longer latencies observed in subcortical neurons were due to additional neuronal processing, for example cortical modulation of these neurons (Malmierca et al., 2009; Ulanovsky et al., 2004). Here, I demonstrated that the AC does not modulate SSA in the MGB, but tend to modulate the latency responses of the neurons in a way that seem to consider the SSA degree of the MGB neurons. I will discuss this phenomenon below (see page 91), when referring to the findings of the deactivation experiments. However, most probably, this phenomenon could simply reflect lower firing rates of the neurons showing strong SSA to a given condition, as the mean first-spike latency can be affected by the response strength.

The presence of strong SSA in the auditory thalamus suggests that SSA is important for the type of processing performed there. For example, the very strong SSA found in the MGM is consistent with its role as a major auditory input to the fear circuit in the amygdala (Antunes and Moita, 2010; Bordi and LeDoux, 1994b; Weinberger, 2010). A recent study demonstrated that this projection participates actively in the mechanisms of fear learning, affecting both the acquisition and recall of discriminative fear and most importantly, the extinction of fear of an auditory cue that was previously paired with shock (Antunes and Moita, 2010). Hence, these authors suggested that the MGM-amygdala pathway is important to suppress fear of neutral or safe auditory stimuli, somehow paralleling the role of SSA in suppressing the responses to repetitive sounds, presumed to be irrelevant and safe. 


\section{Hyperacuity to frequency differences in the $M G B$}

An interesting finding of my research is that SSA in some non-lemniscal MGB neurons was evoked by frequency differences as small as $\Delta \mathrm{f}=0.04$. My study thus revealed the ability of the MGB neurons to discriminate between two very close frequencies, both of which are well within their frequency response area, and with a substantially smaller difference between them than the typical peripheral tuning width. Therefore, the MGB neurons show hyperacuity in the frequency dimension, as previously demonstrated to occur in cat AC (Ulanovsky et al., 2003) and rat IC (Malmierca et al., 2009) neurons. Psychophysically, trained humans are able to discriminate frequencies that are 2-3 orders of magnitude closer to each other than the tuning width of neurons along the auditory pathway (Moore, 1993), indicating the importance of hyperacuity in the auditory brain.

Hyperacuity was originally defined by (Westheimer, 1975; Westheimer, 1981) in the visual system, as a psychophysical ability to discriminate two stimuli for which the spatial offset is smaller than the receptive field size of single retinal photoreceptors. Latter physiological studies demonstrated that visual single neurons also show this property (Lee et al., 1993; Shapley and Victor, 1986; Swindale and Cynader, 1986). However, hyperacuity in the auditory system surpasses that on the visual system, and the mechanisms underlying this property in the two sensory modalities are probably different (Ulanovsky, 2004). Visual hyperacuity seems to rely on spatially- or temporally-discontinuous stimuli (Westheimer et al., 1981; Ulanovsky et al., 2004). Indeed, a temporal interval of more than a few tens of ms destroys the hyperacuity effect (Westheimer, 1981). In contrast, auditory neurons show this property to tones that are displaced both in frequency by $\Delta \mathrm{f}=0.04$ and in time by more than $500 \mathrm{~ms}$ of silence in A1 (Ulanovsky et al., 2003), and up to $425 \mathrm{~ms}$ in IC (Malmierca et al., 2009) and 
MGB neurons (as I demonstrated here). In line with this, Ulanovsky (2004) proposed that auditory hyperacuity requires some sort of 'hyperacute sensory memory', as opposed to visual hyperacuity that might rely on neurons acting as 'discontinuity detectors'.

\section{May SSA be generated in a bottom-up fashion?}

My results demonstrate that $\mathrm{AC}$ deactivation produced non-significant changes in the mean SSA levels over the population and small changes in the individual neurons in the MGB. Furthermore, the temporal dynamics of SSA in the MGB were not affected by AC deactivation. The power-law like dynamics of adaptation over time in the MGB neurons was preserved during cortical deactivation. These findings demonstrate that SSA exhibited by MGB neurons is not a property inherited from the AC but instead can be inherited from lower levels such as the IC and/or generated de novo in the MGB. This is in agreement with the fact that high-SSA neurons in the IC (Malmierca et al., 2009; Perez-Gonzalez et al., 2005) and MGB are mainly onset responders with short latencies. These findings support my previous suggestion that SSA generated at lower levels, can be transmitted in a bottom-up manner and likely be modulated intrinsically at each level of the auditory pathway. Such bottom-up transmission of SSA would enable each level of the auditory system to take the responses of the previous level in order to eliminate as much statistical redundancy as possible (Schwartz and Simoncelli, 2001). 
Gain control mechanism on the MGB responses but not on SSA by the AC

My data also demonstrate that in contrast to SSA the response patterns of the MGB neurons, such as their FRAs, spontaneous activity, discharge rate and latencies, were significantly altered with AC deactivation. Such changes occurred in all neurons, although to different degrees in the different neurons, demonstrating that my results are genuine and not the consequence of technical artefacts. Furthermore, these findings confirm previous studies that used the cooling technique (Nakamoto et al., 2008; Nakamoto et al., 2010; Ryugo and Weinberger, 1976; Villa and Abeles, 1990; Villa et al., 1991; Villa et al., 1999) and electrical stimulation (He, 2003a; He, 2003b) and corroborate the strong corticofugal modulation that the MGB like other subcortical nuclei receive (Bajo et al., 2010; Malmierca and Ryugo, 2011; Nakamoto et al., 2008; Nakamoto et al., 2010; Ojima and Rouiller, 2011; Villa et al., 1991; Villa et al., 1999; Yu et al., 2009). This corticofugal modulation occurs in other sensory modalities, as demonstrated in the visual (Rushmore et al., 2005; Sillito et al., 1994) and somatosensory systems (Ghosh et al., 1994). Here, I demonstrate that the corticofugal modulation does not account significantly for the SSA exhibited in the MGB neurons, but rather, modulates the discharge rate of these neurons in a gain control manner, affecting similarly the responses to the standard and the deviant stimulus. As a result, the degree of SSA quantified by a ratio of driven rates, was largely unaffected by cooling. Indeed, recent studies suggest that the corticofugal system can participate in a gain control process that leads to improved coding of salient stimuli (Robinson and McAlpine, 2009), and possibly underlies auditory attention (He, 2003a) and learninginduced plasticity (Bajo et al., 2010). My results are consistent with the role of the corticofugal pathway in scaling the sensitivity of the MGB neurons to its driving inputs in a gain control fashion. 
Interestingly, although SSA in the MGB is not significantly affected by cortical deactivation in most neurons, I did find a highly significant relationship between SSA and changes elicited by cooling. My findings demonstrate that the corticofugal modulation of the discharge rate of MGB neurons vary significantly with the SSA level that they exhibited, such that the facilitation exerted by the AC on the MGB neurons reduces as the SSA increases, with some high adapting neurons being suppressed (Fig. 28). This relation is not dependent on the anatomical subdivision to which the MGB neurons belong but on the SSA they exhibit, linking this property to the type of corticofugal modulation that they receive.

Since some high SSA neurons from the non-lemniscal MGB received suppressive influence from the corticofugal pathway, inhibition is a possible mechanism underlying such discharge rate modulation, via the thalamic reticular nucleus (TRN; (He, 2003a; Yu et al., 2009), a nucleus that also exhibits SSA (Yu et al., 2009). My results show that the possible inhibition driven by the corticofugal pathway does not underlie SSA on the MGB neurons. Hence, if inhibition plays a role in SSA as suggested in previous studies (Eytan et al., 2003; Richardson et al., 2011; Yu et al., 2009) other pathways should be involved, such as those coming from the IC (Peruzzi et al., 1997) as well as the TRN-MGB connections themselves (Yu et al., 2009).

I also demonstrate that the AC modulates the latency of the MGB neurons, mainly shortening their latencies, as previously shown in some subcortical neurons using electrical stimulation of AC (Luo et al., 2008). This effect becomes less pronounced as the neuronal adaptation increases. The slight latency shift that the strong adapting neurons from the thalamus and the midbrain with the shortest latencies $(<25$ ms) exhibit comparatively to the weaker or non-adapting ones (Malmierca et al., 2009) may be due to a weaker cortical influence that mainly shortens the latency of the MGB 
neurons. The MGB neurons maintained a shorter latency to the deviant than to the standard, during cortical deactivation, as in the previous experiments of my thesis, demonstrating that this latency phenomenon is not of cortical origin. The fact that the non-adapting neurons are mainly facilitated and their latencies shortened by corticofugal modulation can be achieved by direct excitation from the $\mathrm{AC}$ and/or by a release of inhibitory inputs coming from neurons in the thalamus and in its input stations (ICMGB projection; Bartlett et al., 2000; Peruzzi et al., 1997) via TRN inhibition on these inhibitory inputs.

My findings taken together demonstrate that the AC and the corticofugal pathway provide a gating or gain control mechanism (He, 2003a; Robinson and McAlpine, 2009; Villa and Abeles, 1990; Villa et al., 1991; Yu et al., 2009) modulating the general responses of the MGB neurons, without changing significantly SSA in this thalamic nucleus. However, a subset of neurons had their acoustic responsiveness eliminated with cortical deactivation (4 in the MGD; 2 in the MGV; the other was not histologically localized). These data are in agreement with the drivers and modulators hypothesis proposed originally by Sherman and Guillery (Guillery, 1995; Sherman and Guillery, 1998). The main corticofugal projections to the MGB arise from layer VI neurons whose terminals are mostly small and modulatory (Bajo et al., 1995; Bartlett et al., 2000; Ojima and Rouiller, 2011; Ojima, 1994; Rouiller and Welker, 1991). In addition, a few pyramidal neurons from layer $\mathrm{V}$ with large terminal buttons of the driver type project to the MGD and MGV subdivisions (Bajo et al., 1995; Bartlett et al., 2000; Ojima and Rouiller, 2011; Ojima, 1994; Rouiller and Welker, 1991). These seven neurons that ceased firing during cooling had none or very low levels of SSA (CSI < 0.28), agreeing with my main result that SSA in the MGB is not inherited from the AC. 


\section{Technical considerations on the deactivation experiments}

The cooling technique (Payne et al., 1996) has been extensively used to study the corticofugal modulation on subcortical nucleus, mainly on the thalamic nucleus of the auditory (Villa et al., 1991; Villa et al., 1999), visual (Baker and Malpeli, 1977) and somatosensory systems (Ghosh et al., 1994). Cooling blocks synaptic transmission through a disruption in the presynaptic $\mathrm{Ca}^{2+}$ channel function and consequently in neurotransmitter release (reviewed by Brooks, 1983), without compromising fibres of passage (Benita and Conde, 1972). Therefore, it is a powerful technique in that it enables the reversible deactivation of limited regions of the brain, disrupting neither the normal structural nor functional integrity of the cooled area, such as the cortex (Yang et al., 2006). However, the lack of damage to the cortex means that it is not possible to use traditional histological techniques to determine the region that was deactivated (Lomber, 1999; Lomber et al., 2007). In this work, I confirmed cortical deactivation in some control experiments by the cessation of activity in the deeper cortical layers of A1, like previously used by Nakamoto and colleagues (2008). Some neurons had a moderate higher firing rate after recovery than before AC cooling, a rebound presumably due to a higher synaptic release probability during re-warning (Volgushev et al., 2004).

In this work, I deactivated the whole AC, to study its influence in the MGB and avoid partial deactivation. Therefore, I cannot determine whether these changes in the MGB are driven by the primary and/or the secondary auditory cortices, or even from which $\mathrm{AC}$ layers is the modulation coming from. The ipsilateral $\mathrm{AC}$ deactivation switched off all the descending inputs to the ipsilateral MGB, since corticofugal fibres terminating in this nucleus are entirely ipsilateral (Bajo et al., 1995; Winer et al., 2001). Likewise, the ipsilateral inputs to the subthalamic regions, such as the IC and cochlear nucleus, were silenced. As I stimulated the ear contralateral to the deactivated AC, the 
possible impact of the non-cooled contralateral $\mathrm{AC}$ on the responses that we recorded in the ipsilateral MGB, through a transsynaptic effect originated in the ascending pathway ipsilateral to the stimulated ear, are negligible (Malmierca et al., 2002).

\section{Multiple time-scales of SSA and sensory memory}

In order to respond more strongly to a rare stimulus, a neuron exhibiting SSA must integrate information about recent stimulus history. SSA therefore embodies a shortterm memory trace that determines the response of the neuron to subsequent stimulation (Jaaskelainen et al., 2007; Nelken et al., 2003; Reches and Gutfreund, 2008). I demonstrated that a polynomial scale-invariant model explained a high proportion of the adaptation of MGB neurons to the standard stimulus. Such a power law model may indicate that adaptation occurs over a range of time-scales (Drew and Abbott, 2006a; Drew and Abbott, 2006b; Wark et al., 2007; Wark et al., 2009), so that in contrast to exponential adaptation, activity more than a few time constants back, although deemphasized, is not discarded. Indeed, SSA in A1 neurons appears to occur on several time scales concurrently, spanning many orders of magnitude, from hundreds of milliseconds to tens of seconds (Ulanovsky et al., 2004).

These time scales include the long timescales that are necessary for measuring the average stimulus probability (Ulanovsky et al., 2004), and are likely required to optimally encode time-varying stimuli (Fairhall et al., 2001; Wark et al., 2007; Wark et al., 2009). Indeed, dealing with natural stimuli that vary over a wide range of timescales requires matching the dynamics of adaptation to those of changes in the stimulus distribution (Lundstrom et al., 2008; Wark et al., 2009; Zilany and Carney, 2010). Power-law adaptation inherently possesses this flexibility, enabling the dynamics of 
adaptation to be scaled depending on stimulus history (Lundstrom et al., 2008; Wark et al., 2009; Zilany and Carney, 2010). Power-law dynamics have been observed in a range of neural systems, from single ion channels and receptors (Friedlander and Brenner, 2009; Toib et al., 1998), to single neurons (Lundstrom et al., 2008), synapses (Wark et al., 2009; Zilany and Carney, 2010), and cognitive behaviour (Drew and Abbott, 2006b).

Moreover, the multiple timescales of adaptation of SSA as demonstrated in A1 parallel the behaviour of large neuronal populations as recorded in human event-related potentials (Costa-Faidella et al., 2010). SSA was therefore proposed as a candidate neuronal mechanism for auditory sensory memory and deviance detection as reported in human MMN studies (Haenschel et al., 2005; Jaaskelainen et al., 2004; Nelken and Ulanovsky, 2007). However, the MMN component occurs at 100-250 ms after the onset of an acoustic change, while SSA occurs at much shorter latencies (Malmierca et al., 2009; Ulanovsky et al., 2004; von der Behrens et al., 2009). Indeed, a recent study based on neuronal recordings and evoked local field potentials in the rat found enhanced responses to deviants in the evoked local field potentials but did not find the late deviant response component that would have been the equivalent to the human MMN (von der Behrens et al., 2009). Thus, SSA has been suggested to lie upstream of MMN generation. Recent studies in humans demonstrated that deviance detection can take place as early as $30 \mathrm{~ms}$ after stimulus onset, suggesting that early change detection processes occur upstream of MMN generation (Grimm et al., 2010; Slabu et al., 2010). As in the animal models that have been studied, deviance detection in humans occurs at multiple levels in the auditory pathway, from the brainstem up to higher-order cortical areas (Grimm et al., 2010; Slabu et al., 2010). 
Herein, I demonstrate that the latencies of high SSA neurons in the MGB span a range between approximately $10 \mathrm{~ms}$ to $250 \mathrm{~ms}$ (Kimura et al., 2009), covering the range of the different components of the MMN in humans (Grimm et al., 2010; Haenschel et al., 2005; Slabu et al., 2010) and rats (Sambeth et al., 2004b; Sambeth et al., 2004a). The majority of the high SSA neurons in the MGM subdivision had onset responses with short latencies, and could be participants in a bottom-up stream of SSA (Kimura et al., 2009). However, some high SSA neurons in the MGB had very long onset latencies ( $>150 \mathrm{~ms}$ ) and some neurons had two different components in their response, i.e., a short latency component $(<40 \mathrm{~ms})$ together with a long latency one $(>150 \mathrm{~ms})$. The timing of the long latency components of these neurons is similar to the range of the latencies of the MMN component of human event-related potentials $(\sim 200 \mathrm{~ms}$; Escera et al., 1998; Haenschel et al., 2005; Näätänen, 1992). This suggests that there might be some relationship between the SSA exhibited by this population of neurons and the MMN component. My data and those of others who found evidence of MMN subcortically (reviewed in (Winkler et al., 2009) indicate that MMN may be generated by processes that include both bottom-up (Malmierca et al., 2009) and intracortical processing (Szymanski et al., 2009; Ulanovsky et al., 2003; Ulanovsky et al., 2004).

\section{Synaptic depression as a possible mechanism underlying SSA}

Although the neuronal intrinsic properties and/or synaptic mechanisms that lead to SSA are unknown, SSA cannot be explained by inhibitory and adaptive mechanisms that reduce responsiveness of the neuron to all inputs (Ulanovsky et al., 2003). In view of this, synaptic depression can be a potential mechanism underlying SSA (Chung et al., 2002; Rothman et al., 2009). Unlike mechanisms that reduce responsiveness to all 
inputs, synaptic depression is input-specific, and causes the responses of a neuron to depend on the previous history of afferent firing, thus enhancing its sensitivity to nonrepeated stimuli (Abbott et al., 1997; Rothman et al., 2009). Synaptic depression creates an input-specific gain-control mechanism, scaling the sensitivity of the neuron to all of its driving inputs (Abbott et al., 1997; Rothman et al., 2009), and can explain a variety of time scales of adaptation (Varela et al., 1997). Therefore, synaptic depression may underlie rapid neuronal adaptation such as SSA (Chung et al., 2002; Ulanovsky et al., 2003), and is compatible with the participation of additional mechanisms linked to neuronal intrinsic properties, such as ionic currents (Abolafia et al., 2010), that can transform SSA at each level of the auditory pathway.

\section{Final remarks}

In conclusion, in my $\mathrm{PhD}$ research I demonstrate that the MGB has substantial SSA and strongly represents frequency change detection. My work thus provide the missing link between the auditory midbrain and the auditory cortex demonstrating that SSA in the auditory thalamus shares many characteristics with the SSA exhibited in these centres, as expected from their connections. Moreover, I demonstrate that the corticofugal pathway exerts a gain control modulation of the responses of the MGB neurons but does not drive or transform SSA in this nucleus. I therefore suggest that this property could be generated in a bottom-up fashion throughout the auditory pathway, as a pre-attentive gating involved in reducing sensory input to behaviourally relevant aspects.

The role of SSA expressed in IC and MGB in shaping SSA in A1 is not yet clear, and it may well be that SSA in A1 is generated and/or modulated cortically. Nevertheless, the presence of strongly-adapting neurons in non-lemniscal divisions of 
the MGB may indicate the active role of these neurons in the generation, transformation or modulation of SSA expressed in other parts of the auditory system. 
CONCLUSIONS 
1. A significant percentage of neurons in the auditory thalamus adapt in a stimulus-specific manner.

2. Neurons in the medial and dorsal divisions of the auditory thalamus show the strongest stimulus-specific adaptation, linking this property to the nonlemniscal pathway.

3. Some neurons in the non-lemniscal regions of the auditory thalamus show strong stimulus-specific adaptation even under extreme testing conditions.

4. Some neurons in the non-lemniscal regions of the auditory thalamus show hyperacuity in the frequency domain.

5. The temporal dynamics of adaptation to the standard in neurons of the medial geniculate body are explained by a power law function.

6. Stimulus-specific adaptation in the medial geniculate body is not inherited from the auditory cortex.

7. The auditory cortex modulates the general responses of the thalamic neurons in a gain control fashion.

8. The auditory cortex adjusts thalamic neuronal firing depending on the level of stimulus-specific adaptation exhibited by thalamic neurons. 
SUMMARY IN SPANISH 


\section{INTRODUCCIÓN}

La supervivencia de los animales depende de su capacidad para reaccionar ante situaciones y estímulos nuevos en el ambiente ruidoso, tales como el grito estridente de un depredador en la selva ó el sonido llamativo provocado por el claxon de un coche que se nos acerca cuando atravesamos una calle ruidosa. Así pues, los sonidos raros pueden indicar eventos de importancia a los cuales un individuo debe atender. Saber cómo las neuronas individuales se comportan a lo largo de la vía auditiva y contribuyen para que el cerebro lleve a cabo esta tarea tan importante representa un reto tan difícil como interesante en la investigación actual de las neurociencias.

La detección de sonidos nuevos en el ambiente y su relevancia bio-ecológica, es una de las muchas razones por las que la audición representa un aspecto fascinante y especialmente importante de los sentidos y de la función del cerebro en general. En humanos, la pérdida de audición puede ser socialmente más debilitante que la ceguera, por ello, no es de sorprender que el sistema auditivo se haya desarrollado a lo largo de la evolución hasta el punto de convertirse en una de las obras maestras de la bioingeniería del cuerpo humano (Purves et al., 2001).

\section{El cuerpo geniculado medial}

El cuerpo geniculado medial es el núcleo principal del tálamo auditivo y está constituido por tres subdivisiones principales, definidas tanto desde el punto de vista citoarquitectónico como funcional: ventral, dorsal y medial (Bordi y LeDoux, 1994a; Bordi y LeDoux, 1994b; Morest, 1964; Morest, 1965b; Morest, 1965a; Winer y Morest, 1983; Winer y Morest, 1984; Figs. 1-3). 
El cuerpo geniculado medial es un centro de relevo sináptico obligatorio entre el colículo inferior y la corteza auditiva, recibiendo proyecciones ascendientes desde el colículo inferior (Malmierca, 2003; Peruzzi et al., 1997), en el tronco del encéfalo, y numerosas proyecciones descendientes desde la corteza auditiva (He, 2003a; He, 2003b; Lee y Winer, 2005a; Lee y Winer, 2008a; Malmierca, 2003; Winer et al., 2001; Figs. 1 y 4).

Las subdivisiones dorsal y medial constituyen las regiones no lemniscales del cuerpo geniculado medial; mientras que la subdivisión ventral forma parte de la vía puramente auditiva o lemniscal. Las regiones no lemniscales son morfológica y funcionalmente distintas de la región lemniscal (Bordi y LeDoux, 1994b; Bordi y LeDoux, 1994a; Edeline et al., 1999; Malmierca, 2003; Figs. 2 y 3): la región lemniscal se dedica al procesamiento de las características básicas del estímulo acústico mientras que las regiones no lemniscales procesan características más complejas de los sonidos. Las porciones no lemniscales parecen estar implicadas en la integración de estímulos con diferentes modalidades sensoriales (y no exclusivamente auditivas) tales como en el procesamiento del lenguaje, el aprendizaje auditivo, y/o el significado emocional del estímulo auditivo, entre otros (Kimura et al., 2007; Komura et al., 2001; Komura et al., 2005; Winer et al., 2005). La división medial proyecta directamente a la amígdala y está involucrada en el fenómeno de 'condicionamiento aversivo al miedo' (Antunes y Moita, 2010; Bordi y LeDoux, 1994b; Bordi y LeDoux, 1994a).

Aunque el cuerpo geniculado medial es un centro nervioso fundamental en el procesamiento de la información auditiva, tradicionalmente se le ha considerado como un mero núcleo de relevo y transmisión de información sensorial desde los centros subcorticales hacia corteza. A pesar de ello, y al igual que otros núcleos talámicos, cada vez hay mas evidencias que sugieren que el cuerpo geniculado medial procesa y regula 
activamente el paso de la información sensorial y modula las señales sensoriales (Alitto y Usrey, 2003; Sherman, 2007). Esta modulación es posible gracias a interacciones dinámicas entre las proyecciones ascendientes que recibe desde núcleos subtalámicos y las proyecciones corticofugales (Scannell et al., 1999), que actúan como 'activadores' y 'moduladores' (Guillery y Sherman, 2002; Llano y Sherman, 2008; Figs. 4-7).

Una de las características más llamativas del cuerpo geniculado medial es la cantidad de proyecciones descendientes que recibe desde la corteza auditiva. En la rata, estas proyecciones sobrepasan en 10 veces la magnitud de las proyecciones ascendientes (Kimura et al., 2004; Kimura et al., 2005; Kimura et al., 2007; Ojima y Rouiller, 2011; Winer, 2006; Winer y Lee, 2007; Fig. 1). Todas las subdivisiones del cuerpo geniculado medial reciben proyecciones corticofugales, bien sea terminando directamente sobre las neuronas principales del cuerpo geniculado medial y/ó terminando indirectamente en neuronas de proyección GABAérgicas del núcleo reticular del tálamo, cuyas neuronas proyectan al cuerpo geniculado medial, ejerciendo un fuerte efecto inhibitorio en todas las subdivisiones (He, 2003a; He, 2003b; Villa, 1990; Yu et al., 2004; Fig. 4). La proyección corticofugal se origina principalmente en las neuronas piramidales de la capa VI de la corteza auditiva. Estas neuronas dan lugar a botones terminales pequeños y de naturaleza modulatoria (Figs. 6 y 7). Además, existe otra proyección menos numerosa que se origina en las neuronas piramidales de la capa $\mathrm{V}$ y que da lugar a botones terminales grandes capaces de producir respuestas postsinápticas de tipo activador (Bajo et al., 1993; Bartlett et al., 2000; Llano y Sherman, 2008; Ojima, 1994; Rouiller y Welker, 1991; Rouiller y Welker, 2000; Figs. 6 y 7).

Estudios previos empleando la técnica de enfriamiento cortical ó bien la estimulación eléctrica han demostrado que esta proyección descendente modula de manera significativa las respuestas de las neuronas del cuerpo geniculado medial (He, 
2002; He, 2003a; He, 2003b; Ryugo y Weinberger, 1976; Villa et al., 1991; Villa et al., 1999; Fig. 7). Estos estudios sugieren que las proyecciones corticofugales participan en mecanismos activos de control de ganancia, modulando la transmisión de la información sensorial ascendente (He, 2003a; He, 2003b; Villa et al., 1991).

\section{La detección de sonidos novedosos}

La capacidad para reaccionar ante estímulos novedosos que surgen del entorno es fundamental para la supervivencia de los organismos y, de hecho, puede considerarse que la detección de la novedad es una función general del sistema nervioso. De este modo, la ocurrencia de un estímulo novedoso en el entorno dispara una cascada de sucesos neurológicos que implican la percepción, la atención, el aprendizaje y la memoria. Es fácil encontrar ejemplos que ilustran como los sucesos novedosos atraen poderosamente nuestra atención (piénsese en el ruido repentino que produce la rotura de un cristal) y dejan una huella más en la memoria. Ranganath y Rainer (2003) distinguen dos tipos de novedad: la novedad a la estimulación y la novedad contextual. Los efectos de la novedad a la estimulación pueden evidenciarse a través de los cambios conductuales y neurológicos acaecidos cuando un estímulo es repetido, mientras que la novedad contextual se pone de manifiesto cuando un estímulo ocurre en un en un contexto inesperado (por ejemplo, cuando un individuo desnudo entra repentinamente en una clase).

A pesar de la relevancia adaptativa y funcional de la detección (y codificación) de la novedad, todavía no se conocen los mecanismos neuronales responsables de esta atracción preferente de la atención y de ese recuerdo facilitado. Recientemente, se ha propuesto que la capacidad de los estímulos (que alertan) o novedosos para disparar el 
procesamiento atencional estaría mediada fundamentalmente a través de las proyecciones noradrenérgicas originadas en el locus cerúleos que se dirigen hacia el tálamo y el cerebro basal anterior (a través del núcleo basal de Meynert). La activación de la atención sostenida del cerebro basal anterior a través de la proyección colinérgica se produce gracias a un procesamiento atencional 'de arriba-abajo', es decir, focalizado sobre la estimulación entrante y la selección de estímulos (Sarter et al., 2001). Estudios de registro unitario en ratas que se están moviendo libremente han demostrado que las neuronas del locus ceruleus descargan potenciales de acción ante estímulos novedosos, que éstas se habitúan rápidamente y que, seguidamente, liberan noradrenalina (Giovannini et al., 2001).

En la modalidad auditiva, la detección de la novedad se ha demostrado en humanos, dónde ha sido estudiada ampliamente (Escera et al., 1998; Escera et al., 2003; Näätänen, 1992; Näätänen et al., 1992; Tintinen et al., 1994), pero también se sabe que ocurre en monos (Javitt et al., 1994) y en gatos (Csepe et al., 1987b; Csepe et al., 1987a), pudiéndose cuantificar a partir del llamado potencial de disparidad, extraído mediante técnicas de promedio del electroencefalograma (Fig. 8). El potencial de disparidad (al que nos referiremos en adelante por su abreviatura anglosajona, es decir, mismatch negativity, 'MMN') se genera en la corteza auditiva ante la ocurrencia de un estímulo auditivo contextualmente novedoso (estímulo discrepante); esto es, con la presentación improbable e inesperada de un estímulo físicamente distinto ocurrido dentro de una secuencia de estimulación repetitiva (Fig. 8).

Este fenómeno es sensible a la secuencia de estimulación y depende de la probabilidad del estímulo discrepante en dicha secuencia de estimulación. El hecho de que las respuestas al estímulo discrepante sean más constantes que a los estímulos que ocurren con más frecuencia en la secuencia (frecuentes) se interpreta como una 
indicación de que el cerebro almacena de manera efectiva una 'memoria sensorial' de los estímulos frecuentes, a la que va comparando a medida que los estímulos van surgiendo (Näätänen, 1992; Näätänen et al., 2001).

\section{Adaptación específica al estímulo}

Recientemente se ha demostrado que hay neuronas que detectan sonidos novedosos en la corteza auditiva (Szymanski et al., 2009; Ulanovsky et al., 2003; Ulanovsky et al., 2004; von der Behrens et al., 2009), en el colículo inferior (Malmierca et al., 2009; Perez-Gonzalez et al., 2005; Reches y Gutfreund, 2008; Zhao et al., 2011) y en el núcleo reticular talámico (Yu et al., 2009). Estas neuronas se adaptan específicamente a sonidos repetidos en una secuencia de estimulación, pero vuelven a responder cuando son 'sorprendidas' por un sonido nuevo que aparece aleatoriamente en esa misma secuencia, i.e., exhiben adaptación específica al estímulo. Este tipo de secuencia de estimulación se denomina 'secuencia oddball' y es muy similar a las secuencias de estímulos que se utilizan para producir el fenómeno del MMN. Por eso, y porque además tienen varias características comunes, se cree que la adaptación específica al estímulo puede ser el correlato neuronal del MMN (Ulanovsky et al., 2003; Ulanovsky et al., 2004; Fig. 9). No obstante, hay todavía debates al respecto ya que no se ha demostrado fehacientemente este correlato (von der Behrens et al., 2009). La adaptación específica al estímulo es un tipo de adaptación rápida y altamente sensible a la estadística del estímulo que depende de las probabilidades relativas del estímulo común y del estímulo discrepante, del contraste de frecuencias (ó diferencia física existente entre los dos estímulos) así como de la frecuencia de repetición de los mismos 
(Malmierca et al., 2009; Perez-Gonzalez et al., 2005; Reches y Gutfreund, 2008; Ulanovsky et al., 2003).

Aunque no hay duda de que la adaptación específica al estímulo es una propiedad de las neuronas del tálamo auditivo, la contribución del cuerpo geniculado medial en la generación de adaptación específica al estímulo y la detección de la novedad se desconoce. Yu y cols. (2009) han mostrado niveles de adaptación específica al estímulo muy altos en el núcleo reticular talámico de la rata. Sin embargo, un estudio reciente en el cuerpo geniculado medial del ratón (Anderson et al., 2009) ha mostrado niveles de adaptación específica al estímulo comparativamente mucho más bajos que los descritos en el colículo inferior de la rata (Malmierca et al., 2009), en la corteza auditiva del gato (Ulanovsky et al., 2003) y en el núcleo reticular talámico (Yu et al., 2009). Teniendo en cuenta las conexiones del cuerpo geniculado medial con el colículo inferior y la corteza auditiva, sería esperable que los niveles de adaptación específica al estímulo en el cuerpo geniculado medial fueran al menos iguales a los encontrados en estos núcleos, en condiciones similares. Además, conviene subrayar que los estudios en el IC de la rata han demostrado que la adaptación específica al estímulo es más evidente y presenta valores más robustos en las regiones corticales del colículo inferior, o sea en las regiones no lemniscales de este núcleo (Malmierca et al., 2009; Perez-Gonzalez et al., 2005). Estos resultados concuerdan con estudios previos donde se ha demostrado que la adaptación es más intensa en las cortezas auditivas secundarias (Schreiner y Cynader, 1984) y asociativas (Irvine y Huebner, 1979) que en la corteza auditiva primaria. Sin embargo, la corteza auditiva primaria es la primera estación lemniscal de la vía auditiva donde la adaptación específica al estímulo se manifiesta de manera generalizada y robusta (Ulanovsky et al., 2003). Por todo ello, se ha propuesto que la adaptación específica al estímulo es una propiedad emergente de la corteza auditiva y 
que actuaría como una propiedad de orden superior en el procesamiento sensorial, pudiendo ser transmitida en un proceso de arriba a abajo a los núcleos subcorticales a través de su proyección corticofugal (Nelken y Ulanovsky, 2007).

\section{HIPOTESIS Y OBJECTIVOS}

Nuestra hipótesis general de trabajo es que la detección de la novedad es un principio básico de organización funcional del sistema auditivo y que el potencial de disparidad (MMN) y las neuronas detectoras de sonidos novedosos son expresiones distintas pero, correlacionadas, de la activación de este sistema detector de la novedad. El conocimiento sobre los mecanismos neurológicos implicados en la detección de la novedad en el sistema auditivo pasa por establecer las posibles relaciones funcionales entre estas neuronas y el potencial de disparidad (MMN). Para ello, es fundamental caracterizar la naturaleza de las respuestas de estas mismas neuronas en los diferentes niveles de la vía auditiva. Puesto que desconocemos en gran medida los detalles de este

tipo de adaptación en el cuerpo geniculado medial y que los estudios existentes son en gran medida discutibles (Anderson et al., 2009; Ulanovsky et al., 2003; Yu et al., 2009), pensamos que es necesario un estudio detallado de caracterización fisiológica de la adaptación específica al estímulo en este centro talámico. 
1) Considerando que el cuerpo geniculado medial recibe sus proyecciones desde el colículo inferior, la corteza auditiva y el núcleo reticular talámico, y que en todos ellos se ha demostrado la existencia de neuronas con altos niveles de adaptación específica al estímulo, las neuronas del cuerpo geniculado medial deberán presentar niveles de adaptación semejantes, para condiciones de estimulación comparables. Además, a semejanza de lo que ocurre en el colículo inferior, la adaptación debe de ser más fuerte en las regiones no lemniscales del cuerpo geniculado medial.

2) Teniendo en cuenta que el cuerpo geniculado medial recibe una proyección corticofugal masiva que modula las respuestas de este núcleo talámico y que la corteza auditiva primaria es la región lemniscal donde la adaptación específica al estímulo se encuentra más generalizada y robusta en la vía auditiva, siendo sus niveles de adaptación específica al estímulo comparables a los de las regiones no lemniscales del colículo inferior, existe la posibilidad de que la adaptación específica al estímulo de las estaciones subcorticales y, entre ellas, la que existe en el cuerpo geniculado medial, sea heredada y/ó modulada desde la corteza auditiva, a través de dicha proyección descendente. 
Para comprobar estas hipótesis hemos llevado a cabo dos estudios complementarios, con los siguientes objetivos:

1) Hacer registros extracelulares de neuronas unitarias en las diferentes subdivisiones del cuerpo geniculado medial, para determinar si las neuronas en este núcleo auditivo exhiben adaptación-específica al estímulo, en un grado similar al de las neuronas de la corteza auditiva, del colículo inferior y del núcleo reticular talámico. Además, este trabajo nos permitirá determinar si hay diferencias entre la adaptación existente en las neuronas de las diferentes subdivisiones, y si a semejanza del colículo inferior, las neuronas de la vía no lemniscal presentan mayor grado de adaptación que las de la vía lemniscal.

2) Hacer registros extracelulares de neuronas unitarias en las diferentes subdivisiones del cuerpo geniculado medial, mientras desactivamos reversiblemente la corteza auditiva y, con ella, la proyección descendiente a los núcleos subcorticales, incluyendo al cuerpo geniculado medial, usando la técnica de enfriamiento desarrollada por Lomber y cols. (1999). De esta forma, podremos determinar si la adaptación específica al estímulo que exhiben las neuronas en el cuerpo geniculado medial es heredada y/ó modulada por la corteza a través de la proyección corticofugal. 


\section{MATERIALES Y METODOS}

En estos experimentos hemos empleado 51 ratas pigmentadas (Rattus norvegicus, Rj: Long-Evans), cuyo peso oscilaba entre 150 y 250 gramos. De estos 51 animales, hemos usado 34 para hacer registros unitarios en el cuerpo geniculado medial, para caracterizar la adaptación-específica al estímulo en este núcleo talámico. Los 17 animales restantes los hemos utilizado subsecuentemente en los experimentos de desactivación reversible de corteza auditiva usando la técnica de enfriamiento.

\section{Procedimientos quirúrgicos y registros electrofisiológicos}

Todos los experimentos se llevaron a cabo de acuerdo a las normas y reglas establecidas por el Comité de Ética de la Universidad de Salamanca. Hemos anestesiado los animales mediante una inyección intraperitoneal de uretano $(1.5 \mathrm{~g} / \mathrm{Kg}, 20 \%$ solución; Sigma Aldrich Inc). Una vez anestesiados, les hicimos una traqueotomía para canular la traquea y administramos sulfato de atropina subcutáneamente $(0.05 \mathrm{mg} / \mathrm{Kg})$ reducir las secreciones bronquiales.

A continuación, colocamos el animal en un aparato estereotáctico con las barras de los oídos modificadas para facilitar el acoplamiento de los altavoces de estimulación acústica. Las barras están diseñadas de forma que encajan precisamente en el meato auditivo externo de la rata, sin provocar ningún daño a la membrana timpánica. Tras la colocación de las barras, hemos comprobado visualmente la comunicación del meato auditivo con el exterior para permitir la estimulación acústica a través de ellas (Hernández et al., 2005). La temperatura del animal se mantuvo constante monitorizándola a $38 \pm 1^{\circ} \mathrm{C}$ mediante una manta térmica. Finalmente, hicimos una 
trepanación por encima del cuerpo geniculado medial (en todos los animales) y otra por encima de la corteza auditiva (en los 17 animales de los experimentos de cooling). Al final de cada experimento de electrofisiología, hicimos una lesión para localizar posteriormente histológicamente las neuronas, tiñendo el tejido con el método de Nissl.

La presentación de los estímulos auditivos y el registro electrofisiológico se ha realizado dentro de una cabina aislada acústica y eléctricamente. Hemos manipulado el electrodo de registro (1-2 M 2 ; Merrill y Ainsworth, 1972) desde el exterior mediante un micromanipulador accionado con un motor piezoeléctrico (Burleigh 6000) y accionado por control remoto, permitiéndonos alcanzar el cuerpo geniculado medial para registrar extracelularmente sus neuronas. Presentamos estímulos monoaurales en el oído contralateral al cuerpo geniculado medial dónde hicimos los registros. Los estímulos se generaron mediante un sistema controlado por ordenador, usando un equipo TDT system 2 (Tucker-Davis Technologies) y un programa informático desarrollado en la Universidad de Washington (descrito en detalle en Faure et al., 2003; Perez-Gonzalez et al., 2005).

Los potenciales de acción se registraron usando un amplificador BIOAMP (TDT), se amplificaron (x10.000) y se filtraron (TDT DB4; filtro pasa-altas fc: $500 \mathrm{~Hz}$; filtro pasa-bajas fc: $3 \mathrm{kHz}$ ) antes de pasar por un discriminador de espigas (TDT SP1) para ser transferidos y almacenados en un ordenador que además controlaba todos los programas de registro y estimulación.

\section{Paradigma de estimulación}

Para caracterizar la adaptación específica al estímulo en las neuronas del cuerpo geniculado medial, empleamos un paradigma de estimulación probabilística, 
desarrollado por Ulanovsky y cols. (2003). Este paradigma consiste en presentar secuencias de tonos puros de dos frecuencias distintas, (f1 y f2; en 400 presentaciones), cada una de las cuales se presentan aleatoriamente en la secuencia y con distinta probabilidad de ocurrencia: una se repetía frecuentemente (frecuencia común) y la otra tenía poca probabilidad de ocurrencia (frecuencia rara). Lógicamente, las dos frecuencias elegidas estaban dentro del área de respuesta de la neurona (Fig. 9), entre 10-40 dB por encima del umbral.

Para estudiar en profundidad qué parámetros generan adaptación específica al estímulo, hemos usado diferentes condiciones de estimulación, que incluyen: 1) diferentes probabilidades relativas entre las dos frecuencias (ratio de ocurrencia de la frecuencia común/rara en \%: 90/10\% y 70/30\%); 2) diferentes distancias entre las dos frecuencias(contraste entre frecuencias, $\Delta \mathrm{f}=0.37,0.10$ ó 0.04 , donde $\Delta \mathrm{f}$ es la diferencia

de frecuencia normalizada según $(\mathrm{f} 2-\mathrm{f} 1) /(\mathrm{f} 2 * \mathrm{f} 1)^{1 / 2}$; dónde estos valores se corresponden, respectivamente, a los valores de $0.526,0.141$ y 0.057 octavas); 3 ) diferentes intervalos entre estímulos: ISI $=2000 \mathrm{~ms}, 500 \mathrm{~ms}, 250 \mathrm{~ms} \mathrm{y} 125 \mathrm{~ms}$, desde el inicio de un estímulo hasta el inicio del siguiente, teniendo cada estímulo una duración de 75 ms.

\section{Índices para cuantificar la adaptación específica al estímulo de las} neuronas

En nuestro estudio hemos adoptado los índices desarrollados por Ulanovsky y colaboradores (2003), utilizados recientemente en varios estudios de adaptación específica al estímulo en el sistema auditivo (por ejemplo, Malmierca et al., 2009; Reches y Gutfreund, 2008; Yu et al., 2009) para cuantificar la adaptación específica al estímulo. 
Asimismo, hemos calculado el índice de adaptación específica al estímulo específico de cada frecuencia, SI (fi) ( $\mathrm{i}=1$ ó 2 ), en el que $\mathrm{SI}(\mathrm{fi})=[\mathrm{d}(\mathrm{fi})$ $\mathrm{s}(\mathrm{fi})] /[\mathrm{d}(\mathrm{fi})+\mathrm{s}(\mathrm{fi})]$, donde: $\mathrm{d}(\mathrm{fi})$ son las respuestas (en número de espigas por estímulo) a la frecuencia fi cuando ésta es la frecuencia rara (baja probabilidad); y s(fi) son las respuestas a la frecuencia fi cuando ésta es la frecuencia común (alta probabilidad). Hemos cuantificado la adaptación específica al estímulo para las dos frecuencias en cada condición de estimulación, a través del índice común de adaptación específica al estímulo (CSI) a través de la formula CSI $=[\mathrm{d}(\mathrm{f} 1)+\mathrm{d}(\mathrm{f} 2)-\mathrm{s}(\mathrm{fl})-$ $\mathrm{s}(\mathrm{f} 2)] /[\mathrm{d}(\mathrm{f} 1)+\mathrm{d}(\mathrm{f} 2)+\mathrm{s}(\mathrm{f} 1)+\mathrm{s}(\mathrm{f} 2)]$. Estos índices reflejan como la respuesta a una determinada frecuencia es más pequeña cuando ésta se presenta como la frecuencia común, comparativamente a la respuesta a esta misma frecuencia cuando se presenta cómo la rara. Ambos índices varían entre -1 y 1, siendo positivos si la respuesta al tono raro es más grande que la respuesta a ese mismo tono cuando es común.

En los experimentos que llevamos a cabo para caracterizar la adaptación específica al estímulo en el cuerpo geniculado medial hemos calculado estos índices para múltiples y diferentes combinaciones de estimulación usadas para cada neurona (probabilidades, contrastes de frecuencias e intervalos entre estímulos). Por esta razón, tenemos varios índices de SI y CSI para cada neurona, de acuerdo con el número de combinaciones que hemos estudiado.

\section{Desactivación reversible de la corteza usando la técnica de enfriamiento}

En esta serie de experimentos, hemos registrado neuronas en el cuerpo geniculado medial antes, durante y después de desactivar reversiblemente la corteza auditiva usando la técnica de enfriamiento. Para enfriar la corteza auditiva fabricamos 
artesanalmente una cánula de enfriamiento de $1 \mathrm{~mm}$ de diámetro fabricada a partir de una aguja hipodérmica de acero inoxidable $(23 \mathrm{G})$ que fue modelada para amoldarse a la superficie cortical (Lomber et al., 1999; Fig. 10). A continuación posicionamos estereotácticamente la cánula de enfriamiento sobre la corteza auditiva con sumo cuidado, de forma que englobase tanto el área de la corteza auditiva primaria cómo el de la secundaria (Doron et al., 2002). De esta manera, desactivamos totalmente la corteza auditiva a fin de evitar efectos específicos debidos a una desactivación parcial.

El enfriamiento se llevo a cabo haciendo circular metanol, enfriado por hielo seco, a través de la cánula de enfriamiento, usando una bomba peristáltica (Fig. 10). La temperatura se monitorizó continuamente a través de una sonda termostática (Omega HH506RA multiterm) conectada a la unión de la cánula de enfriamiento. De esta forma pudimos obtener una temperatura de $3^{\circ} \pm 1^{\circ} \mathrm{C}$ controlando el flujo de metanol (Lomber et al., 1999) que permitía reducir la temperatura de las capas profundas de la corteza a $20{ }^{\circ} \mathrm{C}$, puesto que las proyecciones corticofugales que deseamos desactivar con destino al núcleo geniculado medial se originan mayoritariamente en la capa VI, con una menor proporción en la capa V (Bajo et al., 1995; Bartlett et al., 2000; Kimura et al., 2004; Kimura et al., 2005; Kimura et al., 2007; Ojima y Rouiller, 2011; Winer y Prieto, 2001; Figs. 6 y 7). 


\section{RESULTADOS}

Como mencionamos anteriormente, nuestro trabajo consta de dos objetivos principales: 1) caracterizar la adaptación específica al estímulo en el cuerpo geniculado medial y 2) investigar si la corteza auditiva ejerce algún efecto en la adaptación específica al estímulo exhibida por las neuronas en este núcleo talámico. Para conseguir estos objetivos, hemos llevado a cabo dos series de experimentos: en la primera serie (parte primera), hicimos registros electrofisiológicos de neuronas individuales en el cuerpo geniculado medial usando el paradigma de estimulación probabilística; y en la segunda serie (parte segunda), desactivamos reversiblemente la corteza auditiva utilizando la técnica de enfriamiento para silenciar sus neuronas y la proyección descendiente ipsilateral al tálamo auditivo.

\section{Parte Primera: Caracterización de la adaptación especifica al estímulo adaptación específica al estímulo en el cuerpo geniculado medial}

Para este estudio, hemos registrado 93 neuronas aisladas en las tres subdivisiones principales del cuerpo geniculado medial mientras estimulábamos al animal con dos tonos puros en un paradigma de estimulación probabilística (f1 y f2; 400 presentaciones de estímulo). Hemos localizado histológicamente 60 de las 93 unidades, de las cuales 24 unidades fueran localizadas en la subdivisión dorsal, 18 en la medial y 18 en la ventral.

Algunas neuronas tuvieron una respuesta similar a las dos frecuencias (común y rara), no presentando adaptación específica al estímulo (Fig. 11a). Sin embargo, muchas neuronas mostraran una respuesta mucho más intensa a la frecuencia rara que a la 
común, por ejemplo adaptándose específicamente al estímulo común, demostrando robustamente la presencia de adaptación específica al estímulo (Fig. 11b). Para cuantificar el grado de adaptación específica al estímulo de las neuronas hemos calculado el valor de CSI para cada condición presentada (Fig. 12). Cómo cada neurona ha sido registrada en varias condiciones, tenemos más valores de CSI que de neuronas registradas ( $\mathrm{n}=372$ puntos en la Fig. 12).

La figura 13 muestra que, de media, la tasa de descarga en nuestra población de neuronas registradas (en número de espigas por estímulo) ha bajado al disminuir el intervalo inter-estímulo (es decir, al aumentar la frecuencia de repetición del estímulo). Muy probablemente, este efecto refleja una forma de adaptación no-específica, puesto que afecta de igual forma a las respuestas frente al estímulo común y al raro (Fig. 13). La figura 14 muestra este efecto de reducción de tasa de descarga, en una neurona con un alto grado de adaptación específica al estímulo, localizada en la subdivisión medial del cuerpo geniculado medial.

En toda la población, los valores más elevados de adaptación específica al estímulo se observaron en las siguientes combinaciones de condiciones: 1) los contrastes de frecuencias más grandes $(\Delta \mathrm{f}=0.37$ y 0.10$) ; 2)$ los intervalos entreestímulo intermedios (ISI = 250 y 500 ms); y 3) la menor probabilidad del estímulo raro (90/10\%; Fig. 15). Para estas condiciones, algunas neuronas presentaron niveles de adaptación específica al estímulo extremos, respondiendo casi exclusivamente a las primeras presentaciones del estímulo común (Fig. 14).

Las neuronas que presentaran niveles mas elevados de adaptación específica al estímulo estaban localizadas en la división medial y dorsal del cuerpo geniculado medial (Figs. 15-17). Sin embargo, solamente frecuencias de repetición muy altas fueran capaces de provocar adaptación específica al estímulo en algunas neuronas de la 
división ventral, aunque estos niveles fueron siempre mucho más bajos (CSI < 0.4; Fig. 15 y 18). Esto sugiere la importancia de la vía no lemniscal en este tipo de adaptación en el cuerpo geniculado medial. Asimismo, algunas neuronas de las regiones no lemniscales exhibieran altos niveles de adaptación específica al estímulo en condiciones muy extremas: para un intervalo entre-estímulo de 2000 ms (Figs. 14, 15 y 19) ó para un contraste de frecuencias de apenas $0.14 \operatorname{octavas}(\Delta \mathrm{f}=0.04$; Figs. $15 \mathrm{y} 16)$.

Para estudiar la dinámica de adaptación a lo largo del tiempo, hemos calculado la media de las respuestas de la población (en espigas por estímulo) a lo largo de las 400 presentaciones, tanto para las condiciones de intervalo entre-estímulos intermedias (ISI $=500$ y $250 \mathrm{~ms}$ ) como para los diferentes $\Delta \mathrm{f}$ registrados para la probabilidad 90/10\% (Fig. 20). Este análisis demuestra que la población de las neuronas adaptadas $(\mathrm{CSI}>0.18)$ disminuye fuertemente su tasa de descarga al estímulo común a partir de las primeras presentaciones del estímulo (Fig. 20). El modelo que mejor se ha ajustado a la adaptación al estímulo común fue un modelo de regresión polinomial inverso [ $\mathrm{f}=$ $\mathrm{y} 0+(\mathrm{a} / \mathrm{x})]$ (Fig. 20).

Las neuronas con altos niveles de adaptación específica al estímulo tenían principalmente respuestas de tipo encendido de corta latencia, aunque también hemos observado algunas neuronas de tipo tónico y de larga latencia que también presentaban altos grados de adaptación (Fig. 21-23). 


\section{Parte segunda: modulación cortical de la adaptación específica al}

estímulo en el cuerpo geniculado medial

Para este estudio hemos registrado 51 neuronas que estaban distribuidas en las tres subdivisiones principales del cuerpo geniculado medial, antes, durante y después de desactivar la corteza auditiva por enfriamiento. En estos experimentos, hemos utilizado el mismo paradigma y las condiciones que en los experimentos descritos en el apartado primero producían más adaptación $(\Delta \mathrm{f}=0.10$, un ISI $=250 \mathrm{~ms}$ y la probabilidad 90/10\%). Todas las neuronas, excepto 3 que no se recuperaron completamente tras enfriamiento, fueron incluidas en el análisis. Las 48 restantes se recuperaron completamente y todos los análisis subsecuentes se realizan en esta población (por ejemplo, Figs. 24-27). Hemos localizado 46 de las 48 neuronas en sus correspondientes subdivisiones del cuerpo geniculado medial: 24 unidades fueran localizadas en la subdivisión dorsal, 12 en la ventral y 9 en la medial.

El resultado principal que hemos obtenido en estos experimentos es que las neuronas que mostraban adaptación específica al estímulo antes del enfriamiento (30 de las 48 neuronas; CSI > 0.18) no han perdido esta propiedad durante la desactivación cortical, y mantuvieron niveles significativos de adaptación específica al estímulo (Figs. 25-27; Wilcoxon signed rank test, $Z=-1.290$, n.s.). Asimismo, hemos comprobado que la dinámica de adaptación de las neuronas a lo largo del tiempo es similar antes y durante la desactivación cortical (Fig. 27c, d). No obstante, la desactivación de la corteza, ha producido alteraciones o cambios en otras propiedades de la respuesta electrofisiológica de las neuronas, tales cómo: los patrones espectrales de respuesta (Figs. 25 y 26); la tasa de actividad espontánea (las unidades en la Fig. 25 han reducido su actividad espontánea; la unidad en la Fig. 26a-1, ha aumentado su actividad 
espontánea); la tasa de descarga (las unidades en las Figs. 25 y 26m-x fueran suprimidas; la unidad en la Fig. 26a-1 fue facilitada; Fig. 28) y las latencias (Fig. 29).

La media de la tasa de descarga en la población, evocada por ambos estímulos, fue significativamente más baja durante la desactivación cortical (solo 9 de las 48 neuronas aumentaron su tasa de descarga; por ejemplo, Fig. 26a-1) que cuando la corteza estaba activa (Wilcoxon signed rank test: $\mathrm{Z}=-4.913$ y -4.667 , estímulo raro y común, respectivamente, $\mathrm{P}<0.001$, ambos estímulos; Fig. 28a, c). Tras el enfriamiento cortical y posterior recuperación de la corteza a la temperatura normal, las neuronas del cuerpo geniculado medial recuperaron la tasa de disparo (Wilcoxon signed rank test: $Z=$ -0.369 y -0.944, n.s., estímulo raro y común, respectivamente; Fig. 28b, c; e.g., Figs. 2426).

Aunque la reducción en la tasa de descarga haya sido significativa en ambas poblaciones (neuronas con adaptación versus neuronas sin adaptación), esta reducción fue mayor en la población de las neuronas sin adaptación específica al estímulo (Wilcoxon signed rank test: $\mathrm{Z}=-3.72, \mathrm{P}<0.001$, ambos estímulos) que en la población de neuronas con adaptación específica al estímulo (Wilcoxon signed rank test: $\mathrm{Z}=-3.22$ y -2.56, estímulo raro y común, respectivamente, $\mathrm{P}<0.01$, ambos estímulos; comparar Fig. 27c, d). Por ello, podemos concluir que la corteza afecta de manera diferente ala tasa de disparo de las neuronas del geniculado según cuales sean sus diferentes grados de adaptación (Fig. 28d, e). 


\section{DISCUSSIÓN}

El resultado principal de nuestra tesis doctoral demuestra que la adaptación específica a estímulos es una propiedad electrofisiológica presente en un alto porcentaje de neuronas del cuerpo geniculado medial. Nuestro trabajo, supone el primer estudio detallado y completo, que analiza minuciosamente la adaptación específica a estímulos frente a múltiples condiciones de estimulación, analizando además las diferentes divisiones del cuerpo geniculado medial. Los resultados demuestran que la adaptación específica a estímulos en el cuerpo geniculado medial es comparable a la descrita en el colículo inferior de la rata (Malmierca et al., 2009), la corteza auditiva del gato (Ulanovsky et al., 2003) y el núcleo reticular talámico de la rata (Yu et al., 2009), para condiciones similares. Por tanto, podemos concluir que el tálamo auditivo tiene adaptación específica a estímulos y participa en la detección de los cambios de frecuencia en la vía auditiva.

Nuestros resultados, junto con los de otros estudios previos recientes (Anderson et al., 2009; Malmierca et al., 2009; Perez-Gonzalez et al., 2005; Reches y Gutfreund, 2008; Ulanovsky et al., 2003; von der Behrens et al., 2009; Yu et al., 2009; Zhao et al., 2011) demuestran la ubicuidad de la adaptación específica a estímulos en neuronas del sistema auditivo, a partir del tronco del encéfalo, pasando por el tálamo, hasta la corteza auditiva.

Nuestro trabajo demuestra que la adaptación específica a estímulos en el tálamo está directamente asociada a la vía auditiva no lemniscal, puesto que las neuronas que presentaran los niveles más elevados de adaptación se localizan en las divisiones medial y dorsal del cuerpo geniculado medial. Estos resultados, coinciden con estudios previos del colículo inferior, que demuestran que la adaptación específica a estímulos es 
también más prominente y elevada en las cortezas del colículo, es decir, en las regiones no lemniscales (Malmierca et al., 2009; Pérez-González et al., 2005), sugiriendo la importancia de esta vía en este tipo de adaptación.

Nuestros resultados también nos permiten afirmar que las condiciones empleadas para generar un alto grado de adaptación específica a estímulos en el cuerpo geniculado medial son semejantes a las que se utilizaron para el colículo inferior de la rata (Malmierca et al., 2009) y para la corteza auditiva del gato (Ulanovsky et al., 2003). A pesar de ello, conviene destacar que la condición de intervalo inter-estímulo más larga que nosotros empleamos (2000 ms), no se utilizó en el estudio del colículo inferior (Malmierca et al., 2009) y, por eso, no podemos comparar los datos del cuerpo geniculado con los del colículo inferior, para esta condición. Sin embrago, recientemente, Zhao y cols. (2011), han demostrado niveles altos de adaptación específica a estímulos empelando ISI $=1000$ ms; además, datos preliminares de nuestro laboratorio han conseguido también adaptación específica a estímulos en el colículo inferior con estímulos de ISI $=2000$ (Malmierca et al., 2010). Nuestros resultados del cuerpo geniculado medial (ISI $=2000 \mathrm{~ms}$, intervalo entre tonos $>1900 \mathrm{~ms}$ ) pueden ser comparados con los de la corteza auditiva (ISI $=2000 \mathrm{~ms}$, intervalo entre tonos $>1700$ ms). El ISI de 2000 ms corresponde a la condición más extrema para la cual Ulanovsky y cols. (2003) mostraron neuronas unitarias exhibiendo adaptación específica a estímulos en la corteza auditiva primaria $(\mathrm{CSI} \sim 0.3)$. En nuestro trabajo desarrollado en el cuerpo geniculado medial, hemos encontrado valores incluso más altos de CSI para esta condición (hasta $\mathrm{CSI}=0.7$ ), pero debemos hacer hincapié que tales valores solo los hemos encontrado en las regiones no lemniscales del geniculado medial.

La región lemniscal del cuerpo geniculado medial, su subdivisión ventral, recibe proyecciones ascendentes desde el núcleo central del colículo inferior y es la fuente 
principal de proyecciones eferentes a la corteza auditiva primaria $(\mathrm{He}, 2003 \mathrm{a}$; $\mathrm{He}$, 2003b; Lee y Winer, 2005a; Lee y Winer, 2008a). En este contexto, cabe además mencionar que, al igual que en la división ventral del cuerpo geniculado medial, la adaptación específica a estímulos descrita en el núcleo central del colículo inferior (Malmierca et al., 2009) es relativamente alta para la frecuencia de repetición mas rápida empleada (ISI $=125 \mathrm{~ms}$ ). Todo ello sugiere que existe una relación muy directa entre la vía no lemniscal y la adaptación específica a estímulos en los centros auditivos subcorticales.

En la vía lemniscal, sin embargo, los valores de CSI parecen ser bastante más elevados a nivel cortical (Ulanovsky et al., 2003) que subcortical, bien sea en el colículo inferior (Malmierca et al., 2009) ó en el cuerpo geniculado medial. Así, nuestros resultados sugieren que la corteza auditiva primaria es la primera región lemniscal donde la adaptación específica a estímulos es elevada y generalizada (Ulanovsky et al., 2003). Es posible que la adaptación específica a estímulos de la corteza auditiva primaria sea generada en la división ventral del cuerpo geniculado medial y posteriormente amplificada a nivel cortical. Esta posible modulación y aumento de la adaptación específica a estímulos a nivel cortical, puede ocurrir por mecanismos intracorticales (Szymanski et al., 2009; Ulanovsky et al., 2003; Ulanovsky et al., 2004) y/o por las proyecciones existentes desde las regiones no lemniscales del cuerpo geniculado medial, a la corteza auditiva primaria, bien directamente, a través de la división medial del cuerpo geniculado medial (Kimura et al., 2003) ó, indirectamente, a través de las conexiones de procedentes de áreas corticales superiores. Por ejemplo, un estudio reciente (Carrasco y Lomber, 2009a), ha demostrado que la desactivación reversible por enfriamiento de la corteza auditiva secundaria modifica las respuestas de las neuronas en la corteza auditiva primaria, mientras que la corteza auditiva primaria 
no ejerce un efecto similar sobre la corteza secundaria. Por ello, estos autores sugieren que existe un flujo de información unidireccional desde la vía no lemniscal hacia la lemniscal, a nivel cortical pero no al revés. De este modo, es posible que los niveles altos de adaptación específica a estímulos observados en la corteza auditiva primaria por Ulanovsky y cols. (2003) sean debidos a la modulación ejercida por la corteza auditiva secundaria sobre la primaria. Otra posibilidad, que no es excluyente a la anterior, es que la adaptación específica a estímulos pueda ser transferida mediante proyecciones que intervienen en los circuitos cortico-tálamo-corticales, ya que es sabido que estos circuitos permiten interconexiones entre los núcleos auditivos lemniscales y no lemniscales (Bajo et al., 1995; Llano y Sherman, 2008; Winer et al., 1999).

La presencia de niveles altos de adaptación específica a estímulos en el cuerpo geniculado medial sugiere que esta propiedad es importante en el tipo de procesamiento de información que lleva a cabo este núcleo. Por ejemplo, la adaptación específica a estímulos exhibida por las neuronas en su división medial está en concordancia con su participación en las respuestas de condicionamiento aversivo al sonido, pues la división medial del geniculado es la fuente principal de proyecciones auditivas directas a la amígdala (Antunes y Moita, 2010; Bordi y LeDoux, 1994b; Weinberger, 2010).

Otro hallazgo muy importante de nuestra tesis se refiere a la demostración de que la adaptación específica a estímulos se manifiesta incluso en condiciones de estimulación extremas. Ese es el caso para las dos frecuencias cuyo contraste es sumamente pequeño. Así pues, hemos demostramos la capacidad que tienen estas neuronas para discriminar dos frecuencias muy próximas entre si dentro de su campo receptivo, es decir, estas neuronas presentan un alto grado de hiperacuidad en la dimensión espectral del sonido, por lo que también son muy similares, en este sentido, a las neuronas de la corteza auditiva (Ulanovsky et al., 2003) y del colículo inferior 
(Malmierca et al., 2009). A nivel psicofísico, se sabe que los humanos con una formación musical profesional son capaces de discriminar frecuencias que se encuentran entre 2 a 3 órdenes de magnitud más cercanas entre sí que el ancho de banda de las neuronas en toda vía auditiva (Moore et al., 1993). Todo ello indica una gran importancia de esta hiperacuidad en el cerebro auditivo.

Otro aspecto fundamental en nuestro trabajo de tesis doctoral ha sido el estudio del efecto que ejerce la corteza auditiva sobre la adaptación específica a estímulos de las neuronas del cuerpo geniculado, dado que como ya se comentó en la introducción, este centro talámico auditivo está sometido a una influencia cortical muy grande, debido a la masiva cantidad de proyecciones corticofugales que recibe. Para este análisis, hemos utilizado la técnica de enfriamiento cortical (Lomber, 1999; Lomber et al., 1999), con la cual desactivamos la totalidad de la corteza auditiva ipsilateral, así como todas las proyecciones descendientes al cuerpo geniculado medial, ya que las fibras corticofugales que terminan en este núcleo son enteramente ipsilaterales (Bajo et al., 1995; Winer et al., 2001).

La técnica de enfriamiento permite la desactivación reversible de zonas discretas y altamente circunscritas (Lomber, 1999; Lomber et al., 1999; Lomber et al., 2010; Payne et al., 1996) y ha sido extensamente utilizada para estudiar las interacciones funcionales entre diferentes regiones corticales (Carrasco y Lomber, 2009a; Carrasco y Lomber, 2009b; Carrasco y Lomber, 2010; Lomber y Payne, 2000; Lomber y Payne, 2004; Lomber et al., 2007; Lomber y Malhotra, 2008; Lomber et al., 2010; Malhotra et al., 2008; Payne et al., 1996), así cómo la modulación corticofugal de núcleos subcorticales en varios sistemas sensoriales (Ghosh et al., 1994; Lomber et al., 2007; Nakamoto et al., 2010; Rushmore et al., 2006; Villa y Abeles, 1990; Villa et al., 1991). 
Nuestro trabajo es pionero en utilizar esta técnica para estudiar los mecanismos de la adaptación específica a estímulos en la vía auditiva.

Nuestros resultados demuestran que la desactivación de la corteza auditiva no ha producido cambios significativos en la adaptación específica a estímulos observada en el cuerpo geniculado medial, ni en su dinámica de adaptación a lo largo del tiempo. Estos resultados demuestran que la adaptación específica a estímulos en el tálamo auditivo no es heredada de la corteza auditiva a través de las proyecciones corticofugales, sino que, al menos en parte, puede ser generada de novo en el cuerpo geniculado medial y/o puede ser heredada del colículo inferior. Esta hipótesis esta en consonancia con el hecho de que las neuronas del colículo inferior y del cuerpo geniculado medial con niveles elevados de adaptación específica a estímulos presenten mayoritariamente respuestas de tipo encendido y de corta latencia, (Malmierca et al., 2009; Pérez-González et al., 2005), al contrario de lo que ocurre en la corteza auditiva, cuya adaptación específica a estímulos es más elevada en el parte sostenida de las respuestas de sus neuronas (Ulanovsky et al., 2003).

Todo ello sugiere que la adaptación específica a estímulos puede ser generada en niveles inferiores de la vía y que se transmite a lo largo de ésta por un mecanismo de procesamiento del tipo de abajo-arriba. Además, la adaptación específica a estímulos puede ser modulada localmente en cada nivel de la vía auditiva. Este mecanismo de transmisión de abajo-arriba permitirá de esta manera refinar a cada nivel de la vía auditiva, las respuestas de adaptación específica a estímulos procedentes del nivel anterior, y así simplificar la redundancia de información y procesamiento lo más posible (Schwartz y Simoncelli, 2001).

Por último, pero por ello no menos importante, debemos subrayar que, a diferencia de lo que ocurre con la adaptación específica a estímulos, donde hemos 
comprobado que no se ve afectada sustancialmente por la acción cortical, nuestros resultados demuestran que los patrones generales de respuesta de las neuronas (por ejemplo, su actividad espontánea, tasa de descarga y latencias) cambian significativamente con la desactivación cortical. Esto demuestra que la ausencia de un efecto de la corteza en la generación de adaptación específica a estímulos en el cuerpo geniculado medial es un resultado fidedigno y no un simple artefacto debido al modo en que hemos empleado enfriamiento cortical. Asimismo, estos datos confirman estudios previos que utilizaron el enfriamiento cortical (Ryugo y Weinberger, 1976; Villa y Abeles, 1990; Villa et al., 1991; Villa et al., 1999), y la estimulación eléctrica (He, 2003a; He, 2003b; Ojima y Rouiller, 2011), y ratifican la fuerte modulación cortical que reciben las neuronas del cuerpo geniculado medial y de otros niveles subcorticales (Bajo et al., 2010; Malmierca y Ryugo, 2011; Nakamoto et al., 2008; Nakamoto et al., 2010; Villa y Abeles, 1990; Villa et al., 1991; Villa et al., 1999; Yu et al., 2009).

En definitiva, nuestra tesis demuestra que la proyección corticofugal no genera la adaptación específica a estímulos en las neuronas el cuerpo geniculado medial, sino que la corteza ejerce un mecanismo de control de la ganancia que modula las respuestas generales de las neuronas del tálamo. Por ello, podemos concluir que la adaptación específica a estímulos podría ser generada en un mecanismo de abajo-arriba, a lo largo de la vía auditiva, constituyendo en cada estación un filtro previo a la atención, que selecciona únicamente a los estímulos sensoriales relevantes para el individuo. 
CONCLUSIONS IN SPANISH 


\section{CONCLUSIONES}

1. Un porcentaje significativo de neuronas en el tálamo auditivo se adapta de una forma específica al estímulo.

2. Las neuronas de las divisiones medial y dorsal del tálamo auditivo muestran niveles muy altos de adaptación específica a estímulos. Por ello, esta característica está íntimamente asociada a la vía auditiva no lemniscal.

3. Algunas neuronas de las regiones no lemniscales del tálamo auditivo muestran niveles de adaptación específica a estímulos incluso en condiciones de estimulación extremas.

4. Algunas neuronas de las regiones no lemniscales del tálamo auditivo presentan hiperacuidad en el dominio de frecuencias.

5. La dinámica temporal de adaptación al estímulo frecuente se ajusta a una función de tipo potencial.

6. La corteza auditiva no transmite la adaptación específica al estímulo al cuerpo geniculado medial.

7. La corteza auditiva modula las respuestas globales de las neuronas talámicas mediante un mecanismo de control en la ganancia.

8. La corteza auditiva ajusta la descarga neuronal de las neuronas talámicas en función de su nivel de adaptación específica al estímulo. 
CONCLUSIONS IN PORTUGUESE 


\section{CONCLUSÕES}

1. Os neurónios do tálamo auditivo adaptam-se de forma específica a estímulos, i.e., adaptam-se a estímulos frequentes sem que essa adaptação se generalize a estímulos pouco frequentes.

2. Os neurónios das divisões medial e dorsal do tálamo auditivo apresentam níveis muito elevados de adaptação específica a estímulos. Por isso, esta propriedade está intimamente relacionada com a via auditiva não lemniscal.

3. Alguns neurónios das regiões não lemniscais do tálamo auditivo apresentam adaptação específica a estímulos mesmo quando as condições de estimulação são extremas.

4. Alguns neurónios das regiões não lemniscais do tálamo auditivo mostram hiperacuidade no domínio das frequências.

5. A dinâmica de adaptação temporal a estímulos frequentes no corpo geniculado medial ajusta-se a uma função de tipo potencial.

6. O córtex auditivo não transmite a adaptação específica a estímulos ao corpo geniculado medial.

7. O córtex auditivo modula as respostas globais dos neurónios talâmicos através de um mecanismo de controlo de ganho.

8. O córtex auditivo ajusta a descarga dos neurónios talâmicos em função do nível de adaptação específica a estímulos que estes apresentam. 
REFERENCE LIST 
Abbott LF, Varela JA, Sen K, Nelson SB, 1997. Synaptic depression and cortical gain control. Science 275: 220-224.

Abolafia JM, Vergara R, Arnold MM, Reig R, Sanchez-Vives MV, 2010. Cortical Auditory Adaptation in the Awake Rat and the Role of Potassium Currents. Cereb. Cortex.

Aitkin LM, 1973. Medial geniculate body of the cat: responses to tonal stimuli of neurons in medial division. J. Neurophysiol. 36: 275-283.

Alitto HJ, Usrey WM, 2003. Corticothalamic feedback and sensory processing. Curr. Opin. Neurobiol. 13: 440-445.

Anderson LA, Christianson GB, Linden JF, 2009. Stimulus-specific adaptation occurs in the auditory thalamus. J. Neurosci. 29: 7359-7363.

Antunes R, Moita MA, 2010. Discriminative auditory fear learning requires both tuned and nontuned auditory pathways to the amygdala. J. Neurosci. 30: 9782-9787.

Augustine JR, 1996. Circuitry and functional aspects of the insular lobe in primates including humans. Brain Res. Brain Res. Rev. 22: 229-244.

Avissar M, Furman AC, Saunders JC, Parsons TD, 2007. Adaptation reduces spikecount reliability, but not spike-timing precision, of auditory nerve responses. J. Neurosci. 27: 6461-6472.

Baeuerle P, Von Der Behrens W, Gaese B, Kossl M. Stimulus-Specific Adaptation in the Auditory Thalamus of the Mongolian Gerbil. ARO abstr 33, 646. 2009.

Bajo VM, Merchan MA, Lopez DE, Rouiller EM, 1993. Neuronal morphology and efferent projections of the dorsal nucleus of the lateral lemniscus in the rat. J. Comp Neurol. 334: 241-262.

Bajo VM, Nodal FR, Moore DR, King AJ, 2010. The descending corticocollicular pathway mediates learning-induced auditory plasticity. Nat. Neurosci. 13: 253260.

Bajo VM, Rouiller EM, Welker E, Clarke S, Villa AE, De RY, De RF, 1995. Morphology and spatial distribution of corticothalamic terminals originating from the cat auditory cortex. Hear. Res. 83: 161-174.

Baker FH, Malpeli JG, 1977. Effects of cryogenic blockade of visual cortex on the responses of lateral geniculate neurons in the monkey. Exp. Brain Res. 29: 433-444.

Bamiou DE, Musiek FE, Luxon LM, 2003. The insula (Island of Reil) and its role in auditory processing. Literature review. Brain Res. Brain Res. Rev. 42: 143154. 
Bartlett EL, Smith PH, 1999. Anatomic, intrinsic, and synaptic properties of dorsal and ventral division neurons in rat medial geniculate body. J. Neurophysiol. 81: 1999-2016.

Bartlett EL, Stark JM, Guillery RW, Smith PH, 2000. Comparison of the fine structure of cortical and collicular terminals in the rat medial geniculate body. Neuroscience 100: 811-828.

Benita M, Conde H, 1972. Effects of local cooling upon conduction and synaptic transmission. Brain Res. 36: 133-151.

Bordi F, LeDoux JE, 1994a. Response properties of single units in areas of rat auditory thalamus that project to the amygdala. I. Acoustic discharge patterns and frequency receptive fields. Exp. Brain Res. 98: 261-274.

Bordi F, LeDoux JE, 1994b. Response properties of single units in areas of rat auditory thalamus that project to the amygdala. II. Cells receiving convergent auditory and somatosensory inputs and cells antidromically activated by amygdala stimulation. Exp. Brain Res. 98: 275-286.

Bottcher-Gandor C, Ullsperger P, 1992. Mismatch negativity in event-related potentials to auditory stimuli as a function of varying interstimulus interval. Psychophysiology 29: 546-550.

Brenner N, Bialek W, de Ruyter van SR, 2000. Adaptive rescaling maximizes information transmission. Neuron 26: 695-702.

Brooks VB, 1983. Study of brain function by local, reversible cooling. In 'Reviews of physiology, biochemistry and pharmacology. vol. 95. pp. 1-109. SpringerVerlag.

Carandini M, 2000. Visual cortex: Fatigue and adaptation. Curr. Biol. 10: R605-R607.

Carrasco A, Lomber SG, 2009b. Evidence for hierarchical processing in cat auditory cortex: nonreciprocal influence of primary auditory cortex on the posterior auditory field. J. Neurosci. 29: 14323-14333.

Carrasco A, Lomber SG, 2009a. Differential modulatory influences between primary auditory cortex and the anterior auditory field. J. Neurosci. 29: 8350-8362.

Carrasco A, Lomber SG, 2010. Reciprocal modulatory influences between tonotopic and nontonotopic cortical fields in the cat. J. Neurosci. 30: 1476-1487.

Cetas JS, Price RO, Crowe J, Velenovsky DS, McMullen NT, 2003. Dendritic orientation and laminar architecture in the rabbit auditory thalamus. J. Comp Neurol. 458: 307-317.

Chung S, Li X, Nelson SB, 2002. Short-term depression at thalamocortical synapses contributes to rapid adaptation of cortical sensory responses in vivo. Neuron 34: 437-446. 
Clerici WJ, Coleman JR, 1990. Anatomy of the rat medial geniculate body: I. Cytoarchitecture, myeloarchitecture, and neocortical connectivity. J. Comp Neurol. 297: 14-31.

Costa-Faidella J, Grimm S, Slabu L, Díaz-Santaella F, Escera C, 2010. Multiple time scales of adaptation in the auditory system as revealed by human evoked potentials. Psychophysiology. 48: 774-783.

Csepe V, Karmos G, Molnar M, 1987a. Effects of signal probability on sensory evoked potentials in cats. Int. J. Neurosci. 33: 61-71.

Csepe V, Karmos G, Molnar M, 1987b. Evoked potential correlates of stimulus deviance during wakefulness and sleep in cat--animal model of mismatch negativity. Electroencephalogr. Clin. Neurophysiol. 66: 571-578.

Dean I, Robinson BL, Harper NS, McAlpine D, 2008. Rapid neural adaptation to sound level statistics. J. Neurosci. 28: 6430-6438.

deCharms RC, Merzenich MM, 1996. Primary cortical representation of sounds by the coordination of action-potential timing. Nature 381: 610-613.

DeRibaupierre F, 1997. Acoustical information processing in the auditory thalamus and cerebral cortex. In 'Anatomical and functional aspects of the cochlear nucleus' (Ehret, G., and Romand, R., Eds.). pp. 317-397. Oxford Univerity Press. Oxford.

Donishi T, Kimura A, Okamoto K, Tamai Y, 2006. "Ventral" area in the rat auditory cortex: a major auditory field connected with the dorsal division of the medial geniculate body. Neuroscience 141: 1553-1567.

Doron NN, LeDoux JE, Semple MN, 2002. Redefining the tonotopic core of rat auditory cortex: physiological evidence for a posterior field. J. Comp Neurol. 453: $345-360$.

Doucet JR, Molavi DL, Ryugo DK 2003. The source of corticocollicular and corticobulbar projections in area Te1 of the rat. Experimental Brain Research. 153:461-466.

Dragoi V, Sharma J, Sur M, 2000. Adaptation-induced plasticity of orientation tuning in adult visual cortex. Neuron 28: 287-298.

Drew PJ, Abbott LF, 2006a. Extending the effects of spike-timing-dependent plasticity to behavioral timescales. Proc. Natl. Acad. Sci. U. S. A 103: 8876-8881.

Drew PJ, Abbott LF, 2006b. Models and properties of power-law adaptation in neural systems. J. Neurophysiol. 96: 826-833.

Edeline JM, Manunta Y, Nodal FR, Bajo VM, 1999. Do auditory responses recorded from awake animals reflect the anatomical parcellation of the auditory thalamus? Hear. Res. 131: 135-152. 
Escera C, Alho K, Winkler I, Naatanen R, 1998. Neural mechanisms of involuntary attention to acoustic novelty and change. J. Cogn Neurosci. 10: 590-604.

Escera C, Yago E, Corral MJ, Corbera S, Nunez MI, 2003. Attention capture by auditory significant stimuli: semantic analysis follows attention switching. Eur. J. Neurosci. 18: 2408-2412.

Eytan D, Brenner N, Marom S, 2003. Selective adaptation in networks of cortical neurons. J. Neurosci. 23: 9349-9356.

Fairhall AL, Lewen GD, Bialek W, de Ruyter Van Steveninck RR, 2001. Efficiency and ambiguity in an adaptive neural code. Nature 412: 787-792.

Faure PA, Fremouw T, Casseday JH, Covey E, 2003. Temporal masking reveals properties of sound-evoked inhibition in duration-tuned neurons of the inferior colliculus. J. Neurosci. 23: 3052-3065.

Feliciano M, Potashner SJ, 1995. Evidence for a glutamatergic pathway from the guinea pig auditory cortex to the inferior colliculus. J. Neurochem. 65: 1348-1357.

Friedlander T, Brenner N, 2009. Adaptive response by state-dependent inactivation. Proc. Natl. Acad. Sci. U. S. A 106: 22558-22563.

Fuchs PA, 2010. The ear. In 'Auditory Brain OUP Handbook' (Palmer A.R. and Rees A. Eds.). in press. Oxford University Press. Oxford.

Games KD, Winer JA, 1988. Layer V in rat auditory cortex: projections to the inferior colliculus and contralateral cortex. Hear. Res. 34: 1-25.

Gerren RA, Weinberger NM, 1983. Long term potentiation in the magnocellular medial geniculate nucleus of the anesthetized cat. Brain Res. 265: 138-142.

Ghosh S, Murray GM, Turman AB, Rowe MJ, 1994. Corticothalamic influences on transmission of tactile information in the ventroposterolateral thalamus of the cat: effect of reversible inactivation of somatosensory cortical areas I and II. Exp. Brain Res. 100: 276-286.

Giovannini MG, Rakovska A, Benton RS, Pazzagli M, Bianchi L, Pepeu G, 2001. Effects of novelty and habituation on acetylcholine, GABA, and glutamate release from the frontal cortex and hippocampus of freely moving rats. Neuroscience 106: 43-53.

Grimm S, Escera C, Slabu L, Costa-Faidella J, 2010. Electrophysiological evidence for the hierarchical organization of auditory change detection in the human brain. Psychophysiology.

Guillery RW, 1995. Anatomical evidence concerning the role of the thalamus in corticocortical communication: a brief review. J. Anat. 187 ( Pt 3): 583-592.

Guillery RW, Sherman SM, 2002. The thalamus as a monitor of motor outputs. Philos. Trans. R. Soc. Lond B Biol. Sci. 357: 1809-1821. 
Haenschel C, Vernon DJ, Dwivedi P, Gruzelier JH, Baldeweg T, 2005. Event-related brain potential correlates of human auditory sensory memory-trace formation. J. Neurosci. 25: 10494-10501.

Hara K, Harris RA, 2002. The anesthetic mechanism of urethane: the effects on neurotransmitter-gated ion channels. Anesth. Analg. 94: 313-8, table.

$\mathrm{He} \mathrm{J}, 2003 \mathrm{~b}$. Corticofugal modulation on both $\mathrm{ON}$ and $\mathrm{OFF}$ responses in the nonlemniscal auditory thalamus of the guinea pig. J. Neurophysiol. 89: 367381.

He J, 2003a. Corticofugal modulation of the auditory thalamus. Exp. Brain Res. 153: 579-590.

He J, 2002. OFF responses in the auditory thalamus of the guinea pig. J. Neurophysiol. 88: $2377-2386$.

Hefti BJ, Smith PH, 2000. Anatomy, physiology, and synaptic responses of rat layer V auditory cortical cells and effects of intracellular GABA(A) blockade. J. Neurophysiol. 83: 2626-2638.

Hernandez O, Espinosa N, Perez-Gonzalez D, Malmierca MS, 2005. The inferior colliculus of the rat: a quantitative analysis of monaural frequency response areas. Neuroscience 132: 203-217.

Irvine DR, Huebner H, 1979. Acoustic response characteristics of neurons in nonspecific areas of cat cerebral cortex. J. Neurophysiol. 42: 107-122.

Jaaskelainen IP, Ahveninen J, Belliveau JW, Raij T, Sams M, 2007. Short-term plasticity in auditory cognition. Trends Neurosci. 30: 653-661.

Jaaskelainen IP, Ahveninen J, Bonmassar G, Dale AM, Ilmoniemi RJ, Levanen S, Lin FH, May P, Melcher J, Stufflebeam S, Tiitinen H, Belliveau JW, 2004. Human posterior auditory cortex gates novel sounds to consciousness. Proc. Natl. Acad. Sci. U. S. A 101: 6809-6814.

Javitt DC, Steinschneider M, Schroeder CE, Vaughan HG, Jr., Arezzo JC, 1994. Detection of stimulus deviance within primate primary auditory cortex: intracortical mechanisms of mismatch negativity (MMN) generation. Brain Res. 667: 192-200.

Katz Y, Heiss JE, Lampl I, 2006. Cross-whisker adaptation of neurons in the rat barrel cortex. J. Neurosci. 26: 13363-13372.

Kelly JB, 1990. Rat auditory cortex. In 'The cerebral cortex of the rat' (Kolb, B. and Tees, R. C., Eds.). pp. 381-405. The MIT Press, Cambridge, MA

Kilgard MP, Merzenich MM, 1999. Distributed representation of spectral and temporal information in rat primary auditory cortex. Hear. Res. 134: 16-28. 
Kimura A, Donishi T, Okamoto K, Imbe H, Tamai Y, 2007. Efferent connections of the ventral auditory area in the rat cortex: implications for auditory processing related to emotion. Eur. J. Neurosci. 25: 2819-2834.

Kimura A, Donishi T, Okamoto K, Tamai Y, 2004. Efferent connections of "posterodorsal" auditory area in the rat cortex: implications for auditory spatial processing. Neuroscience 128: 399-419.

Kimura A, Donishi T, Okamoto K, Tamai Y, 2005. Topography of projections from the primary and non-primary auditory cortical areas to the medial geniculate body and thalamic reticular nucleus in the rat. Neuroscience 135: 1325-1342.

Kimura A, Donishi T, Sakoda T, Hazama M, Tamai Y, 2003. Auditory thalamic nuclei projections to the temporal cortex in the rat. Neuroscience 117: 1003-1016.

Kimura A, Imbe H, Donishi T, 2010. Efferent connections of an auditory area in the caudal insular cortex of the rat: anatomical nodes for cortical streams of auditory processing and cross-modal sensory interactions. Neuroscience 166: 1140-1157.

Kimura A, Imbe H, Donishi T, 2009. Axonal projections of auditory cells with short and long response latencies in the medial geniculate nucleus: distinct topographies in the connection with the thalamic reticular nucleus. Eur. J. Neurosci. 30: 783-799.

Komura Y, Tamura R, Uwano T, Nishijo H, Kaga K, Ono T, 2001. Retrospective and prospective coding for predicted reward in the sensory thalamus. Nature 412: 546-549.

Komura Y, Tamura R, Uwano T, Nishijo H, Ono T, 2005. Auditory thalamus integrates visual inputs into behavioral gains. Nat. Neurosci. 8: 1203-1209.

Kraus N, McGee T, Littman T, Nicol T, King C, 1994. Nonprimary auditory thalamic representation of acoustic change. J. Neurophysiol. 72: 1270-1277.

LeDoux JE, 1995. Emotion: clues from the brain. Annu. Rev. Psychol. 46: 209-235.

LeDoux JE, Muller J, 1997. Emotional memory and psychopathology. Philos. Trans. R. Soc. Lond B Biol. Sci. 352: 1719-1726.

Lee BB, Wehrhahn C, Westheimer G, Kremers J, 1993. Macaque ganglion cell responses to stimuli that elicit hyperacuity in man: detection of small displacements. J. Neurosci. 13: 1001-1009.

Lee CC, Winer JA, 2005. Principles governing auditory cortex connections. Cereb. Cortex 15: 1804-1814.

Lee CC, Winer JA, 2008a. Connections of cat auditory cortex: I. Thalamocortical system. J. Comp Neurol. 507: 1879-1900.

Lee CC, Winer JA, 2008b. Connections of cat auditory cortex: II. Commissural system. J. Comp Neurol. 507: 1901-1919. 
Liu X, Yan Y, Wang Y, Yan J, 2010. Corticofugal modulation of initial neural processing of sound information from the ipsilateral ear in the mouse. PLoS. One. 5: e14038.

Llano DA, Sherman SM, 2008. Evidence for nonreciprocal organization of the mouse auditory thalamocortical-corticothalamic projection systems. J. Comp Neurol. 507: $1209-1227$.

Lomber SG, 1999. The advantages and limitations of permanent or reversible deactivation techniques in the assessment of neural function. J. Neurosci. Methods 86: 109-117.

Lomber SG, Malhotra S, 2008. Double dissociation of 'what' and 'where' processing in auditory cortex. Nat. Neurosci. 11: 609-616.

Lomber SG, Malhotra S, Hall AJ, 2007. Functional specialization in non-primary auditory cortex of the cat: areal and laminar contributions to sound localization. Hear. Res. 229: 31-45.

Lomber SG, McMillan AJ. 2010. Functional localization of the audiory cortex. In 'The Auditory Cortex' (Winer JA, Schreiner CE, eds). pp 389-405. New York. Springer.

Lomber SG, Meredith MA, Kral A, 2010. Cross-modal plasticity in specific auditory cortices underlies visual compensations in the deaf. Nat. Neurosci. 13: 14211427.

Lomber SG, Payne BR, 2000. Contributions of cat posterior parietal cortex to visuospatial discrimination. Vis. Neurosci. 17: 701-709.

Lomber SG, Payne BR, 2004. Cerebral areas mediating visual redirection of gaze: cooling deactivation of 15 loci in the cat. J. Comp Neurol. 474: 190-208.

Lomber SG, Payne BR, Horel JA, 1999. The cryoloop: an adaptable reversible cooling deactivation method for behavioral or electrophysiological assessment of neural function. J. Neurosci. Methods 86: 179-194.

Lumani A, Zhang H, 2010. Responses of neurons in the rat's dorsal cortex of the inferior colliculus to monaural tone bursts. Brain Res. 1351: 115-129.

Lundstrom BN, Higgs MH, Spain WJ, Fairhall AL, 2008. Fractional differentiation by neocortical pyramidal neurons. Nat. Neurosci. 11: 1335-1342.

Luo F, Wang Q, Kashani A, Yan J, 2008. Corticofugal modulation of initial sound processing in the brain. J. Neurosci. 28: 11615-11621.

Malhotra S, Stecker GC, Middlebrooks JC, Lomber SG, 2008. Sound localization deficits during reversible deactivation of primary auditory cortex and/or the dorsal zone. J. Neurophysiol. 99: 1628-1642.

Malmierca MS, 2003. The structure and physiology of the rat auditory system: an overview. Int. Rev. Neurobiol. 56: 147-211. 
Malmierca MS, Cristaudo S, Perez-Gonzalez D, Covey E, 2009. Stimulus-specific adaptation in the inferior colliculus of the anesthetized rat. J. Neurosci. 29: 5483-5493.

Malmierca MS and Hackett T, 2010. Structural Organization of the ascending auditory pathway. In 'Auditory Brain OUP Handbook' (Palmer AR and Rees A. Eds.). in press. Oxford University Press. Oxford.

Malmierca MS, Hernández O, Antunes FM, Pérez-González D, Izquierdo MA, Covey E, 2010. GABAA Receptors Mediate Stimulus-Specific Adaptation (SSA) in the Auditory Midbrain. ARO abstr. 786.

Malmierca MS, Izquierdo MA, Cristaudo S, Hernandez O, Perez-Gonzalez D, Covey E, Oliver DL, 2008. A discontinuous tonotopic organization in the inferior colliculus of the rat. J. Neurosci. 28: 4767-4776.

Malmierca MS, Merchan MA, Henkel CK, Oliver DL, 2002. Direct projections from cochlear nuclear complex to auditory thalamus in the rat. J. Neurosci. 22: 10891-10897.

Malmierca MS, Ryugo DK, 2011 Descending Connections of Auditory Cortex to the midbrain and Brian Stem. In: 'The Auditory Cortex' (Winer J.A., Schreiner C.E. Eds.). pp. 189-208. Springer. New York.

Malone BJ, Scott BH, Semple MN, 2002. Context-dependent adaptive coding of interaural phase disparity in the auditory cortex of awake macaques. J. Neurosci. 22: 4625-4638.

Malone BJ, Semple MN, 2001. Effects of auditory stimulus context on the representation of frequency in the gerbil inferior colliculus. J. Neurophysiol. 86: 1113-1130.

McMullen NT, Velenovsky DS, Holmes MG, 2005. Auditory thalamic organization: cellular slabs, dendritic arbors and tectothalamic axons underlying the frequency map. Neuroscience 136: 927-943.

Merryll EG, Ainswoth A, 1972. Glass-coated platinum coated tungsten microelectrodes. Med and Biol. Eng 10: 662-672.

Moore DR, 1993. Plasticity of binaural hearing and some possible mechanisms following late-onset deprivation. J. Am. Acad. Audiol. 4: 277-283.

Morest DK, 1964. The neuronal arquitecture of the medial geniculate body of the cat. J. Anat. 98: 611-630.

Morest DK, 1965a. The laminar structure of the medial geniculate body of the cat. J. Anat. 99: 143-160.

Morest DK, 1965b. The lateral tegmental system of the midbrain and the medial geniculate body: Study with Golgi and Nauta methods in cat. J. Anat. 99: 611634. 
Moriizumi T, Hattori T, 1991. Pyramidal cells in rat temporoauditory cortex project to both striatum and inferior colliculus. Brain Res. Bull. 27: 141-144.

Muller JR, Metha AB, Krauskopf J, Lennie P, 1999. Rapid adaptation in visual cortex to the structure of images. Science 285: 1405-1408.

Näätänen R, 1992. Attention and brain function. Lawrence Erlbaum, Hillsdale, New Jersey.

Naatanen R, Paavilainen P, Rinne T, Alho K, 2007. The mismatch negativity (MMN) in basic research of central auditory processing: a review. Clin. Neurophysiol. 118: 2544-2590.

Naatanen R, Tervaniemi M, Sussman E, Paavilainen P, Winkler I, 2001. "Primitive intelligence" in the auditory cortex. Trends Neurosci. 24: 283-288.

Nakamoto KT, Jones SJ, Palmer AR, 2008. Descending projections from auditory cortex modulate sensitivity in the midbrain to cues for spatial position. J. Neurophysiol. 99: 2347-2356.

Nakamoto KT, Shackleton TM, Palmer AR, 2010. Responses in the inferior colliculus of the guinea pig to concurrent harmonic series and the effect of inactivation of descending controls. J. Neurophysiol. 103: 2050-2061.

Nelken I, 2004. Processing of complex stimuli and natural scenes in the auditory cortex. Curr. Opin. Neurobiol. 14: 474-480.

Nelken I, Fishbach A, Las L, Ulanovsky N, Farkas D, 2003. Primary auditory cortex of cats: feature detection or something else? Biol. Cybern. 89: 397-406.

Nelken I, Ulanovsky N, 2007. Mismatch negativity and stimulus-specific adaptation in animal models. Journal of Psycophysiology: 214-223.

Oertel D, 2002. Introduction chapter In 'Integrative functions in the mammalian auditory pathway. Springer handbook of auditory research' (Oertel D, Fay, RR and Popper AN Eds.). pp. 1-5. Springer. New York.

Ojima H, 1994. Terminal morphology and distribution of corticothalamic fibers originating from layers 5 and 6 of cat primary auditory cortex. Cereb. Cortex 4: 646-663.

Ojima H, Rouiller EM, 2011. Auditory Cortical Projections to the Medial Geniculate Body. In: 'The Auditory Cortex' (Winer J.A., Schreiner C.E. Eds.). pp. 171188. Springer, New York.

Palmer AR, Liu LF, Shackleton TM, 2007. Changes in interaural time sensitivity with interaural level differences in the inferior colliculus. Hear. Res. 223: 105-113.

Paxinos G, Watson C, 2005. The Rat Brain in Stereotaxic Coordinates. ElsevierAcademic Press, Burlington. 
Payne BR, Lomber SG, Villa AE, Bullier J, 1996. Reversible deactivation of cerebral network components. Trends Neurosci. 19: 535-542.

Perez-Gonzalez D, Malmierca MS, Covey E, 2005. Novelty detector neurons in the mammalian auditory midbrain. Eur. J. Neurosci. 22: 2879-2885.

Perez-Gonzalez D, Malmierca MS, Moore JM, Hernandez O, Covey E, 2006. Duration selective neurons in the inferior colliculus of the rat: topographic distribution and relation of duration sensitivity to other response properties. J. Neurophysiol. 95: 823-836.

Peruzzi D, Bartlett E, Smith PH, Oliver DL, 1997. A monosynaptic GABAergic input from the inferior colliculus to the medial geniculate body in rat. J. Neurosci. 17: 3766-3777.

Polley DB, Read HL, Storace DA, Merzenich MM, 2007. Multiparametric auditory receptive field organization across five cortical fields in the albino rat. J. Neurophysiol. 97: 3621-3638.

Purves D, Augustine GJ, Fitzpatrick D, et al., Editors. 2001. The auditory system. In 'Neuroscience', 2dn edition. Sunderland (MA): Sianuer Associates.

Ranganath C, Rainer G, 2003. Neural mechanisms for detecting and remembering novel events. Nat. Rev. Neurosci. 4: 193-202.

Reches A, Gutfreund Y, 2008. Stimulus-specific adaptations in the gaze control system of the barn owl. J. Neurosci. 28: 1523-1533.

Reches A, Netser S, Gutfreund Y, 2010. Interactions between stimulus-specific adaptation and visual auditory integration in the forebrain of the barn owl. J. Neurosci. 30: 6991-6998.

Richardson BD, Ling LL, Uteshev VV, Caspary DM, 2011. Extrasynaptic GABA(A) receptors and tonic inhibition in rat auditory thalamus. PLoS. One. 6: e16508.

Robinson BL, McAlpine D, 2009. Gain control mechanisms in the auditory pathway. Curr. Opin. Neurobiol. 19: 402-407.

Rothman JS, Cathala L, Steuber V, Silver RA, 2009. Synaptic depression enables neuronal gain control. Nature 457: 1015-1018.

Rouiller EM, Welker E, 1991. Morphology of corticothalamic terminals arising from the auditory cortex of the rat: a Phaseolus vulgaris-leucoagglutinin (PHA-L) tracing study. Hear. Res. 56: 179-190.

Rouiller EM, Welker E, 2000. A comparative analysis of the morphology of corticothalamic projections in mammals. Brain Res. Bull. 53: 727-741.

Rushmore RJ, Payne BR, Lomber SG, 2005. Functional impact of primary visual cortex deactivation on subcortical target structures in the thalamus and midbrain. J. Comp Neurol. 488: 414-426. 
Rushmore RJ, Valero-Cabre A, Lomber SG, Hilgetag CC, Payne BR, 2006. Functional circuitry underlying visual neglect. Brain 129: 1803-1821.

Ryugo DK, Weinberger NM, 1978. Differential plasticity of morphologically distinct neuron populations in the medical geniculate body of the cat during classical conditioning. Behav. Biol. 22: 275-301.

Ryugo DK, Weinberger NM, 1976. Corticofugal modulation of the medial geniculate body. Exp. Neurol. 51: 377-391.

Saldana E, Feliciano M, Mugnaini E, 1996. Distribution of descending projections from primary auditory neocortex to inferior colliculus mimics the topography of intracollicular projections. J. Comp Neurol. 371: 15-40.

Sambeth A, Maes JH, Brankack J, 2004a. With long intervals, inter-stimulus interval is the critical determinant of the human P300 amplitude. Neurosci. Lett. 359: 143-146.

Sambeth A, Maes JH, Quian QR, Coenen AM, 2004b. Effects of stimulus repetitions on the event-related potential of humans and rats. Int. J. Psychophysiol. 53: 197205.

Sanchez-Vives MV, Nowak LG, McCormick DA, 2000b. Membrane mechanisms underlying contrast adaptation in cat area 17 in vivo. J. Neurosci. 20: 42674285 .

Sanchez-Vives MV, Nowak LG, McCormick DA, 2000a. Cellular mechanisms of longlasting adaptation in visual cortical neurons in vitro. J. Neurosci. 20: 42864299.

Sarter M, Givens B, Bruno JP, 2001. The cognitive neuroscience of sustained attention: where top-down meets bottom-up. Brain Res. Brain Res. Rev. 35: 146-160.

Scannell JW, Burns GA, Hilgetag CC, O'Neil MA, Young MP, 1999. The connectional organization of the cortico-thalamic system of the cat. Cereb. Cortex 9: 277299.

Schreiner CE, Cynader MS, 1984. Basic functional organization of second auditory cortical field (AII) of the cat. J. Neurophysiol. 51: 1284-1305.

Schwartz O, Simoncelli EP, 2001. Natural signal statistics and sensory gain control. Nat. Neurosci. 4: 819-825.

Shapley R, Victor J, 1986. Hyperacuity in cat retinal ganglion cells. Science 231: 9991002 .

Sherman SM, 2007. The thalamus is more than just a relay. Curr. Opin. Neurobiol. 17: 417-422.

Sherman SM, Guillery RW, 1998. On the actions that one nerve cell can have on another: distinguishing "drivers" from "modulators". Proc. Natl. Acad. Sci. U. S. A 95: 7121-7126. 
Sillito AM, Jones HE, Gerstein GL, West DC, 1994. Feature-linked synchronization of thalamic relay cell firing induced by feedback from the visual cortex. Nature 369: 479-482.

Slabu L, Escera C, Grimm S, Costa-Faidella J, 2010. Early change detection in humans as revealed by auditory brainstem and middle-latency evoked potentials. Eur. J. Neurosci.

Smirnakis SM, Berry MJ, Warland DK, Bialek W, Meister M, 1997. Adaptation of retinal processing to image contrast and spatial scale. Nature 386: 69-73.

Smith PH and Spirou GA (2002) From the cochlea to the cortex and back. In 'Integrative functions in the mammalian auditory pathway. Springer handbook of auditory research' (Oertel D, Fay, RR and Popper AN Eds.). pp. 6-71. Springer. New York.

Suga N, Ma X, 2003. Multiparametric corticofugal modulation and plasticity in the auditory system. Nat. Rev. Neurosci. 4: 783-794.

Sun X, Xia Q, Lai CH, Shum DK, Chan YS, He J, 2007. Corticofugal modulation of acoustically induced Fos expression in the rat auditory pathway. J. Comp Neurol. 501: 509-525.

Swindale NV, Cynader MS, 1986. Vernier acuity of neurones in cat visual cortex. Nature 319: 591-593.

Szymanski FD, Garcia-Lazaro JA, Schnupp JW, 2009. Current source density profiles of stimulus-specific adaptation in rat auditory cortex. J. Neurophysiol. 102: 1483-1490.

Tiitinen H, May P, Reinikainen K, Naatanen R, 1994. Attentive novelty detection in humans is governed by pre-attentive sensory memory. Nature 372: 90-92.

Toib A, Lyakhov V, Marom S, 1998. Interaction between duration of activity and time course of recovery from slow inactivation in mammalian brain $\mathrm{Na}+$ channels. J. Neurosci. 18: 1893-1903.

Ulanovsky N, 2004. Neuronal Adaptation in Cat Auditory Cortex. PhD thesis.

Ulanovsky N, Las L, Farkas D, Nelken I, 2004. Multiple time scales of adaptation in auditory cortex neurons. J. Neurosci. 24: 10440-10453.

Ulanovsky N, Las L, Nelken I, 2003. Processing of low-probability sounds by cortical neurons. Nat. Neurosci. 6: 391-398.

Varela JA, Sen K, Gibson J, Fost J, Abbott LF, Nelson SB, 1997. A quantitative description of short-term plasticity at excitatory synapses in layer $2 / 3$ of rat primary visual cortex. J. Neurosci. 17: 7926-7940.

Villa AE, 1990. Physiological differentiation within the auditory part of the thalamic reticular nucleus of the cat. Brain Res. Brain Res. Rev. 15: 25-40. 
Villa AE, Abeles M, 1990. Evidence for spatiotemporal firing patterns within the auditory thalamus of the cat. Brain Res. 509: 325-327.

Villa AE, Rouiller EM, Simm GM, Zurita P, De RY, De RF, 1991. Corticofugal modulation of the information processing in the auditory thalamus of the cat. Exp. Brain Res. 86: 506-517.

Villa AE, Tetko IV, Dutoit P, De RY, De RF, 1999. Corticofugal modulation of functional connectivity within the auditory thalamus of rat, guinea pig and cat revealed by cooling deactivation. J. Neurosci. Methods 86: 161-178.

Volgushev M, Kudryashov I, Chistiakova M, Mukovski M, Niesmann J, Eysel UT, 2004. Probability of transmitter release at neocortical synapses at different temperatures. J. Neurophysiol. 92: 212-220.

von Bèkèsy G, 1960. Experiments in Hearing. Mc Graw-Hill, New York.

von der Behrens W, Bauerle P, Kossl M, Gaese BH, 2009. Correlating stimulus-specific adaptation of cortical neurons and local field potentials in the awake rat. J. Neurosci. 29: 13837-13849.

Wark B, Fairhall A, Rieke F, 2009. Timescales of inference in visual adaptation. Neuron 61: 750-761.

Wark B, Lundstrom BN, Fairhall A, 2007. Sensory adaptation. Curr. Opin. Neurobiol. 17: 423-429.

Weedman DL, Ryugo DK, 1996a. Projections from auditory cortex to the cochlear nucleus in rats: synapses on granule cell dendrites. J. Comp Neurol. 371: 311324.

Weedman DL, Ryugo DK, 1996b. Pyramidal cells in primary auditory cortex project to cochlear nucleus in rat. Brain Res. 706: 97-102.

Weinberger NM, 2010. The medial geniculate, not the amygdala, as the root of auditory fear conditioning. Hear. Res.

Weinberger NM, Bakin JS, 1998. Research on auditory cortex plasticity. Science 280: 1174.

Weinberger NM, Javid R, Lepan B, 1995. Heterosynaptic long-term facilitation of sensory-evoked responses in the auditory cortex by stimulation of the magnocellular medial geniculate body in guinea pigs. Behav. Neurosci. 109: $10-17$.

Westheimer G, 1975. Editorial: Visual acuity and hyperacuity. Invest Ophthalmol. 14: 570-572.

Westheimer G, 1981. Visual hyperacuity. Prog. Sens. Physiol. 1:1-30.

Winer JA, 2006. Decoding the auditory corticofugal systems. Hear. Res. 212: 1-8. 
Winer JA, Diehl JJ, Larue DT, 2001. Projections of auditory cortex to the medial geniculate body of the cat. J. Comp Neurol. 430: 27-55.

Winer JA, Kelly JB, Larue DT, 1999. Neural architecture of the rat medial geniculate body. Hear. Res. 130: 19-41.

Winer JA, Lee CC, 2007. The distributed auditory cortex. Hear. Res. 229: 3-13.

Winer JA, Miller LM, Lee CC, Schreiner CE, 2005. Auditory thalamocortical transformation: structure and function. Trends Neurosci. 28: 255-263.

Winer JA, Morest DK, 1983. The medial division of the medial geniculate body of the cat: implications for thalamic organization. J. Neurosci. 3: 2629-2651.

Winer JA, Morest DK, 1984. Axons of the dorsal division of the medial geniculate body of the cat: a study with the rapid Golgi method. J. Comp Neurol. 224: 344-370.

Winer JA, Prieto JJ, 2001. Layer V in cat primary auditory cortex (AI): cellular architecture and identification of projection neurons. J. Comp Neurol. 434: 379-412.

Winkler I, Denham SL, Nelken I, 2009. Modeling the auditory scene: predictive regularity representations and perceptual objects. Trends Cogn Sci. 13: 532540.

Yang XF, Kennedy BR, Lomber SG, Schmidt RE, Rothman SM, 2006. Cooling produces minimal neuropathology in neocortex and hippocampus. Neurobiol. Dis. 23: 637-643.

Yu XJ, Xu XX, He S, He J, 2009. Change detection by thalamic reticular neurons. Nat. Neurosci. 12: 1165-1170.

Yu YQ, Xiong Y, Chan YS, He J, 2004. In vivo intracellular responses of the medial geniculate neurones to acoustic stimuli in anaesthetized guinea pigs. J. Physiol 560: 191-205.

Zhang X, Giesler GJ, Jr., 2005. Response characterstics of spinothalamic tract neurons that project to the posterior thalamus in rats. J. Neurophysiol. 93: 2552-2564.

Zhao L, Liu Y, Shen L, Feng L, Hong B, 2011. Stimulus-specific adaptation and its dynamics in the inferior colliculus of rat. Neuroscience 181: 163-174.

Zilany MS, Carney LH, 2010. Power-law dynamics in an auditory-nerve model can account for neural adaptation to sound-level statistics. J. Neurosci. 30: 1038010390 . 
ORIGINAL PUBLICATIONS 


\title{
Stimulus-Specific Adaptation in the Auditory Thalamus of the Anesthetized Rat
}

\author{
Flora M. Antunes ${ }^{1}$, Israel Nelken ${ }^{3,4}$, Ellen Covey $^{5}$, Manuel S. Malmierca ${ }^{1,2 *}$ \\ 1 Auditory Neurophysiology Unit, Laboratory for the Neurobiology of Hearing, Institute of Neuroscience of Castilla y León, University of Salamanca, Salamanca, Spain, \\ 2 Department of Cell Biology and Pathology, Faculty of Medicine, University of Salamanca, Salamanca, Spain, 3 Department of Neurobiology, Institute of Life Sciences, The \\ Hebrew University of Jerusalem, Jerusalem, Israel, 4 The Edmond and Lily Safra Center for Brain Sciences, The Hebrew University of Jerusalem, Jerusalem, Israel, \\ 5 Department of Psychology, University of Washington, Seattle, Washington, United States of America
}

\begin{abstract}
The specific adaptation of neuronal responses to a repeated stimulus (Stimulus-specific adaptation, SSA), which does not fully generalize to other stimuli, provides a mechanism for emphasizing rare and potentially interesting sensory events. Previous studies have demonstrated that neurons in the auditory cortex and inferior colliculus show SSA. However, the contribution of the medial geniculate body (MGB) and its main subdivisions to SSA and detection of rare sounds remains poorly characterized. We recorded from single neurons in the MGB of anaesthetized rats while presenting a sequence composed of a rare tone presented in the context of a common tone (oddball sequences). We demonstrate that a significant percentage of neurons in MGB adapt in a stimulus-specific manner. Neurons in the medial and dorsal subdivisions showed the strongest SSA, linking this property to the non-lemniscal pathway. Some neurons in the nonlemniscal regions showed strong SSA even under extreme testing conditions (e.g., a frequency interval of 0.14 octaves combined with a stimulus onset asynchrony of $2000 \mathrm{~ms}$ ). Some of these neurons were able to discriminate between two very close frequencies (frequency interval of 0.057 octaves), revealing evidence of hyperacuity in neurons at a subcortical level. Thus, SSA is expressed strongly in the rat auditory thalamus and contribute significantly to auditory change detection.
\end{abstract}

Citation: Antunes FM, Nelken I, Covey E, Malmierca MS (2010) Stimulus-Specific Adaptation in the Auditory Thalamus of the Anesthetized Rat. PLoS ONE 5(11): e14071. doi:10.1371/journal.pone.0014071

Editor: Jun Yan, Hotchkiss Brain Institute, University of Calgary, Canada

Received July 30, 2010; Accepted October 29, 2010; Published November 19, 2010

Copyright: (C) 2010 Antunes et al. This is an open-access article distributed under the terms of the Creative Commons Attribution License, which permits unrestricted use, distribution, and reproduction in any medium, provided the original author and source are credited.

Funding: Financial support was provided by the Spanish MEC (BFU2009-07286), EU (EUI2009-04083) and JCYL-UE (GR221) to MSM, the EU (EUI2009-04083) and the Israeli Science Foundation (ISF) to IN and the NSF (IOS-0719295) to EC. Support for software development was provided by NIH (NIDCD P30DC004661); FMA held a fellowship from the Spanish MEC (BES-2007-15642). The funders had no role in study design, data collection and analysis, decision to publish, or preparation of the manuscript.

Competing Interests: The authors have declared that no competing interests exist.

*E-mail: msm@usal.es

\section{Introduction}

Rare sounds may indicate events of behavioural importance to which an individual should attend for survival. On the other hand, repeating sounds without behavioural consequences can be assumed to be unimportant. Indeed, neurons at several levels of the auditory system have been shown to signal the occurrence of rare sounds while reducing their responses to repeated ones. The specific adaptation to repeated sounds, which does not generalize to other sounds, is referred to as stimulus-specific adaptation (SSA). Recent SSA studies [1-13] have revealed that SSA in single auditory neurons shares many similarities with Mismatch Negativity (MMN) [5,14-18], and may contribute to auditory scene analysis [19].

The medial geniculate body (MGB) is the principal nucleus of the auditory thalamus and possesses three main subdivisions: ventral (MGV), dorsal (MGD) and medial (MGM) [20-22]. The non-lemniscal divisions are morphologically and functionally different from the lemniscal MGV [21,23-25]. The MGV constitutes the lemniscal part of the auditory thalamus and is thought to process basic acoustic features of the stimulus, whereas the MGD and MGM comprise the non-lemniscal part, and are thought to process more complex features.

The MGB receives ascending inputs from the inferior colliculus (IC) $[21,26,27]$ and massive descending inputs from the auditory cortex (AC; [21,28-32]. SSA is known to be present in the thalamus: $\mathrm{Yu}$ and colleagues [13] demonstrated strong SSA in the reticular nucleus. However, a previous report of SSA in the MGB of mice [1] showed substantially weaker levels of adaptation than those found in AC [10-12] or IC [4] neurons. Given its connections with the $\mathrm{AC}$ and the IC, one would expect neurons in the MGB to show strong SSA as well. In particular, the differences in the SSA exhibited by neurons in the three main subdivisions of the MGB need to be clarified. The mouse MGB study [1] showed SSA in the MGM and in the lemniscal MGV but not in the non-lemniscal MGD subdivision. Nevertheless, the studies of the rat IC $[4,6]$ demonstrated stronger SSA in the nonlemniscal regions than in the lemniscal central nucleus.

Here, using the same oddball paradigm as previously used in AC and IC studies, we recorded from single neurons throughout the rat MGB. We aimed to characterize SSA in its main subdivisions under several conditions hitherto unexplored. Our results demonstrate that MGB neurons exhibit SSA levels as high as those found in the IC and AC. Furthermore, SSA is more prominent in the medial and dorsal subdivisions, linking this property to the non-lemniscal auditory pathway. Thus, we demonstrate that the MGB has substantial SSA and strongly represents frequency change detection. Preliminary results have been presented elsewhere [33-35]. 


\section{Results}

To look for evidence of SSA in the MGB we recorded the responses of single neurons $(n=93)$ while presenting sequences of tones with two different frequencies $\left(f_{1}\right.$ and $f_{2} ; 400$ stimulus presentations) in which the standard and deviant stimuli occurred at different probability ratios $(90 / 10 \%$ or $70 / 30 \%)$, with different frequency intervals $(\Delta \mathrm{f}=0.37,0.10$ or 0.04$)$ and at different repetition rates $(\mathrm{SOA}=2000 \mathrm{~ms}, 500 \mathrm{~ms}, 250 \mathrm{~ms}$ or $125 \mathrm{~ms})$. We localized 60 of the 93 units recorded to one of the three main MGB subdivisions: 24 units were localized to the MGD; 18 to the MGM; and 18 to the MGV. The remaining units could not be localized with confidence and included units close to the borders between subdivisions (15 out of 33 ).

Some neurons had a similar response to the standard and to the deviant stimulus (Fig. 1A). However, many neurons had a much stronger response to the deviant than to the standard stimulus, i.e., they adapted specifically to the standard stimulus (Fig. 1B), indicating the presence of strong SSA.

\section{SSA quantification}

In order to quantify the degree of SSA, we calculated the common SSA index (CSI) of each neuron, for each condition tested. To illustrate the relation between CSI and the responses of the neurons, we plotted the responses, elicited by the deviant versus the standard stimulus, and used different colors for the different CSI values obtained (Fig. 2). This figure shows the responses of the neurons to all conditions tested, and for this reason there are more data points than the number of neurons tested ( $\mathrm{n}=372$ data points for the 93 neurons tested). For those neurons having CSI values close to 0 (blue) for a certain condition, the responses evoked by the standard were similar to those evoked by the deviant stimulus. Since the negative values found were so close to zero, we consider negative CSI values to be the result of variability in the spike counts. We took the most negative CSI value in the data set, -0.18 , to represent the most extreme variance due to random fluctuations in spike counts. Using this measure, we consider the range of CSI between -0.18 and +0.18 as indicating lack of adaptation. CSI values greater than 0.18 indicate that a neuron showed a significant decrease in its response to a given stimulus when it was presented as the standard relative to the response when it was the deviant, i.e., the neuron showed adaptation. CSI values close to +1 (red color) indicated nearcomplete cessation of the responses to the standards (Fig. 2).

\section{Population changes in firing rate across conditions}

Figure 3 illustrates the average responses across the entire population of MGB neurons for the different frequency contrasts

A
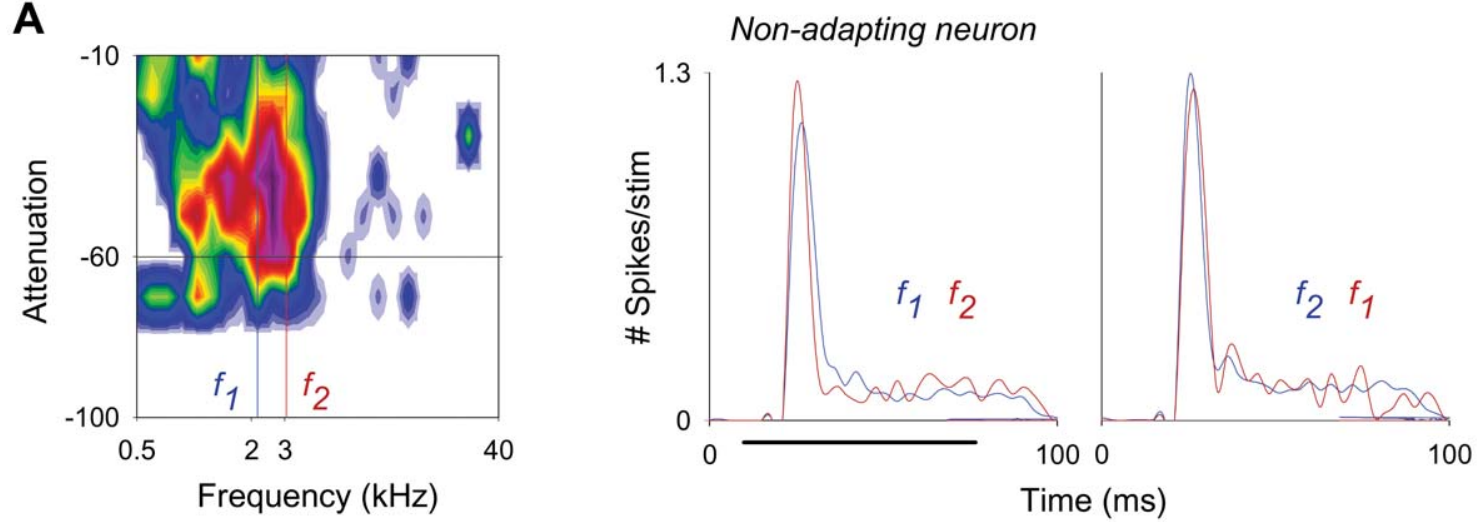

B
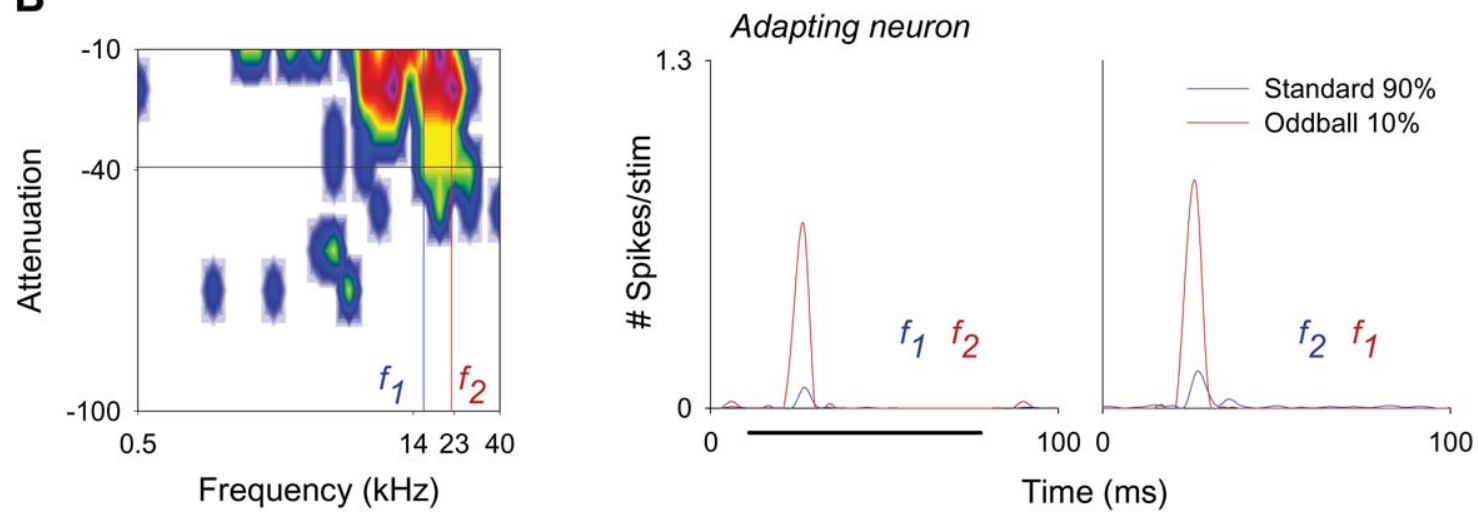

Figure 1. Some MGB neurons exhibit extreme levels of stimulus-specific adaptation. Response of two neurons to pure-tone stimuli of two frequencies ( $\mathrm{f} 1$ and $\mathrm{f} 2$ ), selected from within the frequency response area (left panels), presented in an oddball paradigm $(\mathrm{SOA}=500 \mathrm{~ms} ; \Delta f=0.37)$. Red and blue lines in the peri-stimulus time histograms (PSTHs; second and third panels) represent the neuronal activity (number of spikes/stimulus; bin duration: $3 \mathrm{~ms}$; number of bins: 168) elicited by the deviant tone (10\% probability) and standard tone (90\% probability) respectively, in the first block of stimuli (left PSTHs; $\mathrm{f} 1$ as standard, $\mathrm{f} 2$ as deviant) and in the second block of stimuli (right PSTHs; $\mathrm{f} 2$ as standard, f1 as deviant). Black horizontal lines below the PSTHs in the second panels indicate the duration of the stimulus $(75 \mathrm{~ms})$. The non-adapting neuron (A) has a similar response to the standard and to the deviant frequencies in both blocks of stimuli. In contrast, the adapting neuron (B) shows a much stronger response to the deviant than to the standard frequency in both blocks of stimuli.

doi:10.1371/journal.pone.0014071.g001 


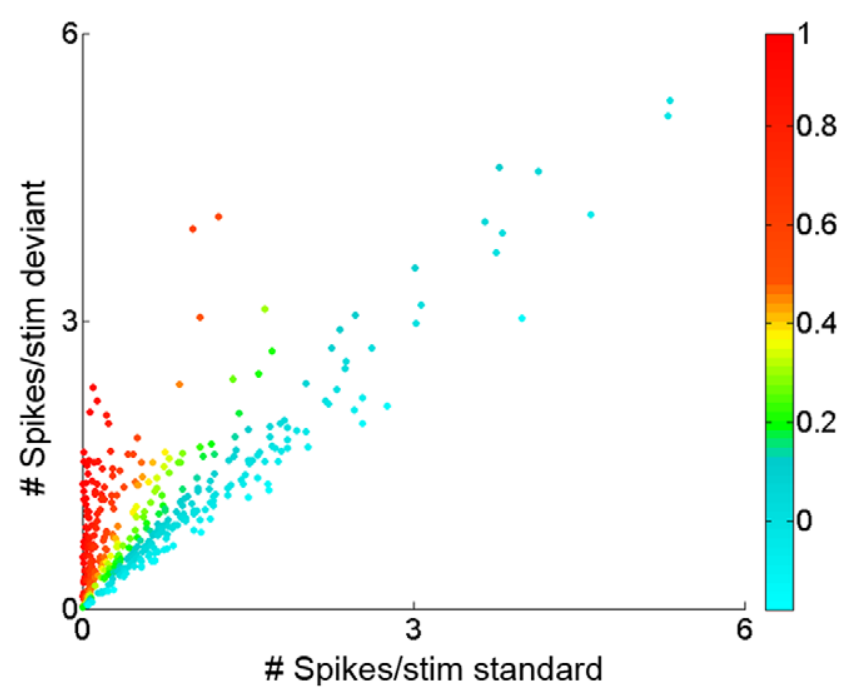

Figure 2. Responses of MGB neurons to the deviant and standard tones across the CSI range. Scatterplot of the response of all neurons to the deviant tone vs response to the standard tone, with points color-coded according to the CSI value (different colors, right color bar). Low CSI values (around 0) correspond to neurons having a similar response to the standard and deviant stimuli, i.e., non-adapting neurons. Higher CSI values reflect a stronger response to the deviant than to the standard stimulus, i.e., adaptation to the standard. CSI values close to +1 (red color) indicate near-complete cessation of the responses to the standard tone. The most strongly responding neurons tended to be non-adapting.

doi:10.1371/journal.pone.0014071.g002

and SOAs (repetition rates) tested at the highest standard-todeviant probability ratio $(90 / 10 \%)$. Each plot shows the mean peristimulus time histograms of the entire population, for each combination of conditions (Fig. 3; red, deviant; blue, standard). On average, the firing rate decreased as SOA decreased, i.e., firing rate was highest at low stimulus repetition rates. This effect presumably represents a form of non-specific adaptation, which affects the responses to both standard and deviant stimuli.

The mean firing rate in response to the deviant was significantly higher than that to the standard under all conditions, except when $\Delta f$ was 0.04 (with a small effect for $\mathrm{SOA}=250 \mathrm{~ms}$; i.e., at a repetition rate of $4 / \mathrm{s}$, even at this small $\Delta f$ ). However, a population analysis of this type is biased disproportionately by neurons with high firing rates. Since the neurons with the largest responses tended to be non-adapting (e.g., compare neurons in Fig. 1A and $\mathrm{B}$, tested for the same conditions; see Fig. 2 for population analysis), the responses of the highly-adapting neurons with lower firing rates are downplayed in Fig. 3.

The data collected at the shortest SOA tested (125 ms) required special treatment, since those neurons that exhibited the highest levels of SSA at higher repetition rates $(\mathrm{SOA}=250 \mathrm{and} / \mathrm{or} 500 \mathrm{~ms}$ [4/s or $2 / \mathrm{s}]$ ) were also those that had the largest overall reduction in their firing at high repetition rates. In the extreme case, many units $(27 / 47)$ that exhibited high levels of SSA for an SOA of $250 \mathrm{~ms}$ completely ceased firing at the shortest SOA (125 ms) and were not included in the analysis for this condition. The remaining units (20/47) maintained some firing when tested at the $125 \mathrm{~ms}$ SOA condition, resulting in high CSI values for all these conditions. Figure 4 displays the responses of one of these highSSA neurons, localized in the MGM subdivision. This neuron reduced substantially its responses for $\mathrm{SOA}=125 \mathrm{~ms}$, although its responses were not completely abolished.

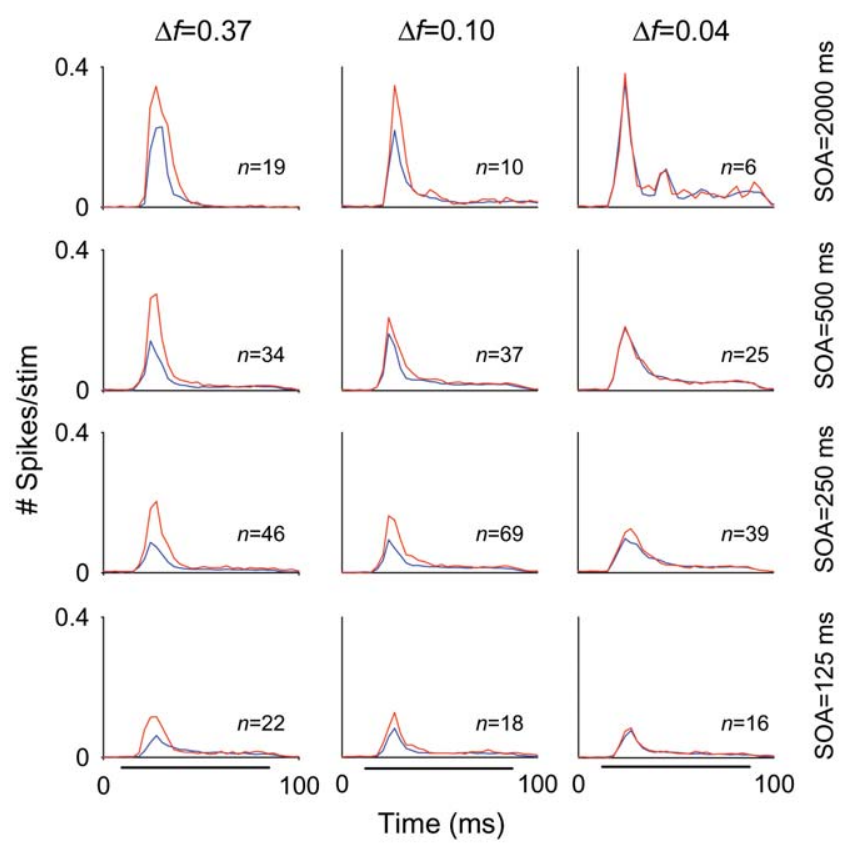

Figure 3. Responses of the population of MGB neurons across stimulation conditions. Averaged post-stimulus time histograms (Bin duration: $3 \mathrm{~ms}$ ) for the entire population of MGB neurons across the different conditions tested ( $\Delta f$ and SOA) for the $90 / 10 \%$ probability condition. The mean firing rate elicited by both stimuli (standard, blue lines; deviant, red lines) decreased directly with SOA (SOA $=2000,500$, 250 and $125 \mathrm{~ms}$; from first to fourth rows, respectively), for the different $\Delta f s$ tested $(\Delta f=0.37,0.10$ and 0.04 ; from first to third columns, respectively). Numbers in each plot indicate the number of neurons for each condition. Black horizontal lines under the PSTHs of the bottom row indicate the duration of the stimulus (75 ms).

doi:10.1371/journal.pone.0014071.g003

\section{General description of SSA across the MGB population}

To analyze SSA across the population of MGB neurons, we plotted the frequency-specific SSA index (SI) for the different conditions separately, and used a different color to identify the neurons that were located in the different subdivisions of MGB (Fig. 5; Red, MGM; Orange, MGD; Blue, MGV; and Gray, nonlocalized units).

For the majority of conditions, the plots show $\operatorname{SI}\left(f_{i}\right)$ values located above the reverse diagonal, which indicates the presence of SSA [10]. The SI values for each frequency pair $\left[\operatorname{SI}\left(f_{1}\right)\right.$ and $\left.\operatorname{SI}\left(f_{2}\right)\right]$ were very similar, leading to a distribution around the diagonal in the upper right quadrant of the plot for most of the values (Fig. 5); this demonstrates that the response did not depend on the frequencies presented, but reflected genuine adaptation elicited by the standard-deviant combination.

Across the entire population, the highest SSA values were found for the largest $\Delta \mathrm{fs}(0.37$ and 0.10$)$ at intermediate SOAs (250 and $500 \mathrm{~ms}$ ) and the lowest deviant probability (90/10\%) conditions (Fig. 5). The plots for these conditions show a cluster of points in the upper right corner (Fig. 5); these points correspond to neurons with an $\operatorname{SI}(f)>0.6$ for both $\mathrm{f}_{1}$ and $\mathrm{f}_{2}$, which represent the highest degree of selectivity to the rare tone. Under these conditions, a high percentage of neurons showed CSI values in the range from 0.6 to 0.99 , revealing strong $\mathrm{SSA}(56 \%$ and $27 \%$ at $\mathrm{SOA}=500$, for $\Delta f=0.37$ and 0.10 , respectively; $46 \%$ at $\mathrm{SOA}=250 \mathrm{~ms}$ for both $\Delta f$ s; Fig. 5). Figures 4 and 6 show two examples of the responses of such neurons, localized to the MGM and MGD, respectively (For the units in Figs. 4 and 6, CSI $>0.82$ when 

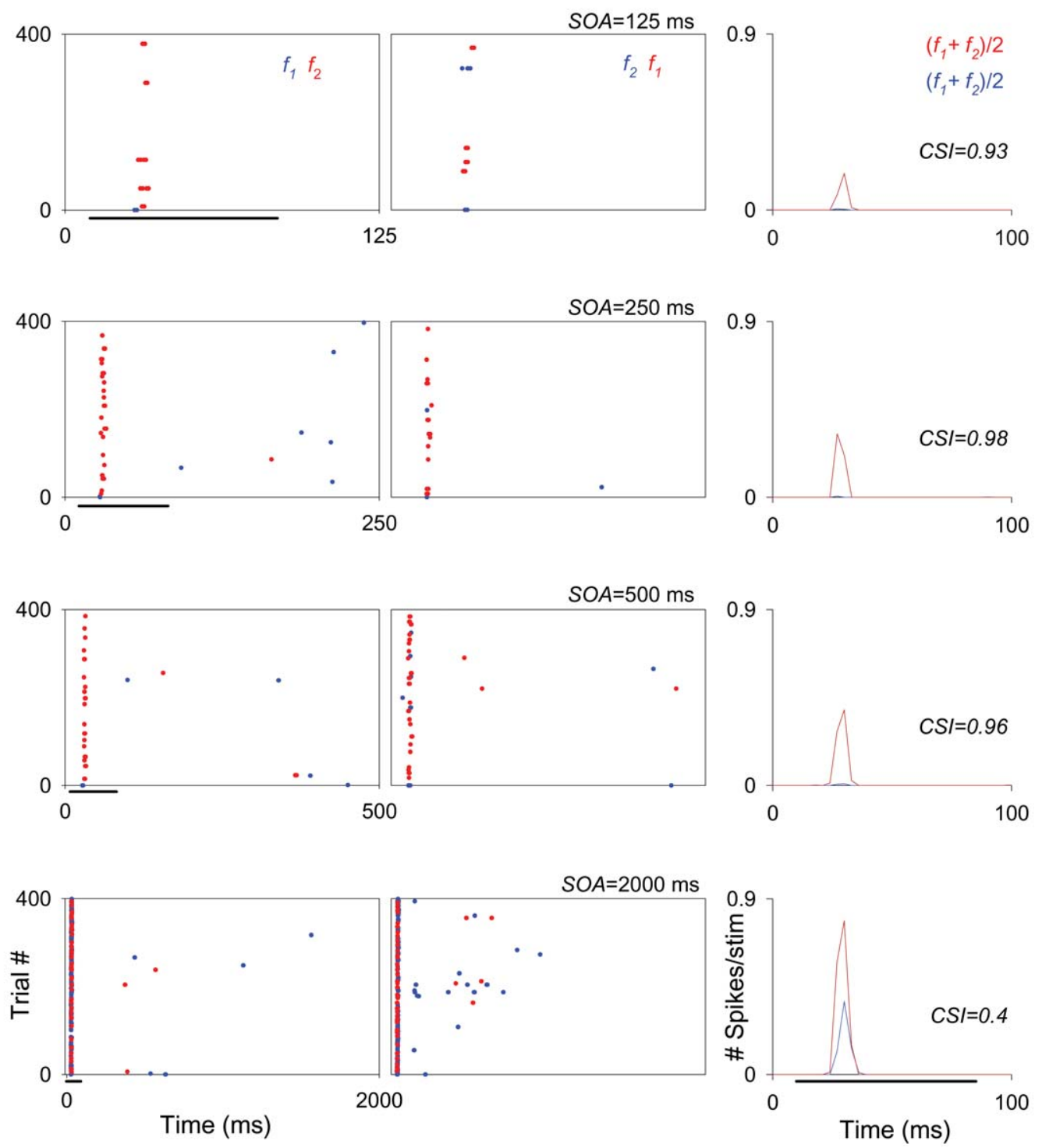

Figure 4. Firing rate decreases as repetition rate increases in the MGB neurons. Example of an MGM neuron showing strong SSA across different SOAs $(125,250,500$ and $2000 \mathrm{~ms}$; from the first to the fourth rows, respectively) at the same $\Delta f(0.10)$. The firing rate of this neuron decreased with decrease in SOA, it exhibited strong SSA even under extreme conditions, i.e., at the combination of a $\triangle f=0.10$ and SOA $=2000 \mathrm{~ms}$ (fourth row). In this figure and subsequent ones (e.g., Figs. 6, 8, 9, 11 and 13), the plots show responses as dot rasters, which plot individual spikes (red dots indicate responses to the deviant; blue dots indicate responses to the standard). Stimulus presentations are stacked along the $y$-axis (trial \#; 400 trials each block). The time (ms) between trials (SOA) corresponds to the $\mathrm{x}$-axis and is also indicated at the top right of each pair of raster plots. Because we tested different SOAs, the plots in the different rows have different $x$-axis scales corresponding to the SOA tested. Left and middle columns in each row represent the two blocks tested for each frequency pair ( $\mathrm{f} 1 / \mathrm{f} 2$ as standard/deviant; and $\mathrm{f} 2 / \mathrm{f} 1 \mathrm{ls}$ standard/deviant, respectively). PSTHs in the right column show the number of spikes/stimulus averaged over the two blocks $[(\mathrm{f} 1+\mathrm{f} 2) / 2$; blue line is standard, red line is deviant]. Black horizontal lines under the plots indicate the duration of the stimulus $(75 \mathrm{~ms})$. The CSI calculated for each SOA condition (each row) is noted as an inset on the PSTHs. doi:10.1371/journal.pone.0014071.g004

$\Delta f \geq 0.1$ and $\mathrm{SOA}=250$ or $500 \mathrm{~ms})$. At the shortest $\mathrm{SOA}(125 \mathrm{~ms})$, some neurons failed to respond at all and for this reason fewer neurons are represented in these plots (Fig. 5). Even so, some neurons maintained a high degree of SSA under this condition (Fig. 4, first row; $\Delta f=0.1$ and $\mathrm{SOA}=125$; $\mathrm{CSI}=0.93$ ).

Although the amount of SSA was reduced for the largest SOA $(2000 \mathrm{~ms})$ and the smallest $\Delta f(0.04)$, we recorded neurons that exhibited robust SSA under each of these conditions (Fig. 5). Figure 4 shows the responses of a neuron that had a reduced, but still high degree of adaptation at an SOA of $2000 \mathrm{~ms}$ (fourth row: $\Delta f=0.10$, CSI $=0.40$; compared to CSI $>0.9$ for shorter SOAs).
Other neurons had CSI $>0.6$ at SOAs of $2000 \mathrm{~ms}$. For the smallest $\Delta f(0.04)$ some neurons had CSI $>0.6$ as well (for $\mathrm{SOA}=250 \mathrm{~ms}$ and $500 \mathrm{~ms}$, respectively; Fig. 5). Figure 6 shows an example of a neuron that had a reduced, but still high degree of adaptation with $\Delta f=0.04 \quad(\mathrm{SOA}=250 \mathrm{~ms}, \mathrm{CSI}=0.58)$. However, no neurons showed SSA when tested with the combination of $\Delta f=0.04$ and $\mathrm{SOA}=2000 \mathrm{~ms}$. This was in fact the only combination out of the 15 tested that did not elicit any SSA in the MGB population (Fig. 5).

The amount of SSA was lower for the $70 / 30 \%$ condition; although some neurons exhibited high SI values under this 
$90 / 10 \%$

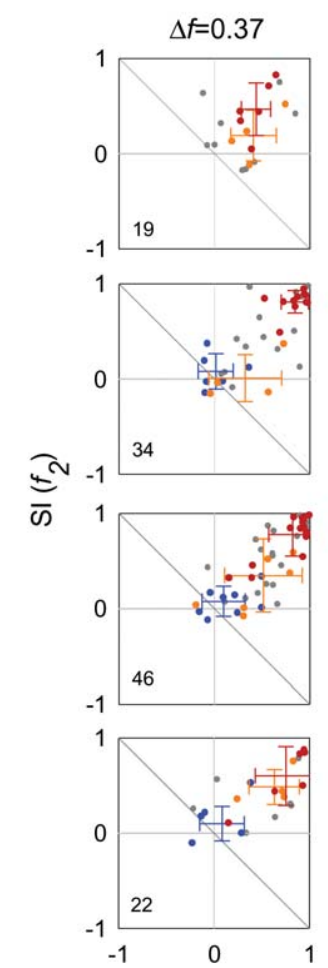

$70 / 30 \%$

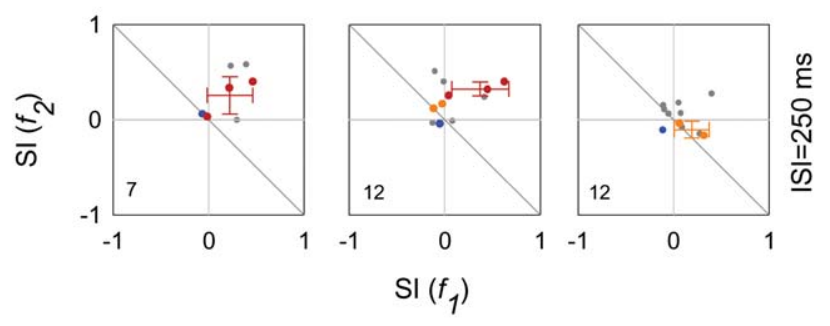

Figure 5. Analysis of SSA across MGB subdivisions in the population of neurons. (A, B) Scatterplots of $S I(f 1)$ versus $(f 2)$, for the different $\Delta f s(0.37,0.10$ and 0.04 , from first to third columns), SOAs ( $2000 \mathrm{~ms}, 500 \mathrm{~ms}, 250 \mathrm{~ms}$, and $125 \mathrm{~ms}$, from first to fourth rows) and probabilities tested (In A, 90/10\%; In B, 70 30\%). Each dot in each panel represents data from one neuron. Neurons that were tested for more than one set of conditions are represented in more than one panel. Numbers in the lower left quadrant of the plots represent the number of neurons tested for each condition. Blue dots represent neurons from the MGV; yellow from the MGD and red from the MGM. Grey dots represent neurons that could not be assigned with certainty to one subdivision. Crosses indicate the mean and standard deviation for the localized neurons (blue for MGV; orange for MGD; and red for MGM). For the majority of conditions $\mathrm{SI}$ ( $f$ i) values lie above the reverse diagonal indicating the presence of SSA. SSA was strongest for the intermediate SOAs (205 and $500 \mathrm{~ms}$ ), the largest $\triangle f_{s}(0.37$ and 0.10$)$ and the $90 / 10 \%$ conditions. SSA was strongest in the MGM, intermediate in the MGD and weaker in the MGV subdivision.

doi:10.1371/journal.pone.0014071.g005

condition, they were lower than for the $90 / 10 \%$ condition at the same SOA and $\Delta f \mathrm{~s}$ (Fig. 5; compare row 3 and row 5).

\section{SSA across MGB subdivisions}

Figure 5 clearly indicates that SSA was stronger in the medial subdivision (red dots), than in the other subdivisions. SSA was smallest in the ventral subdivision (blue dots) and intermediate in the dorsal subdivision (orange dots). Figure 7A shows Nissl stainedsections of the MGB with marked electrolytic lesions, corresponding to the location of neurons recorded in the different MGB subdivisions. To analyze the topographical organization of SSA within the MGB subdivisions, we constructed Voronoi tessellations [36] for the combination of conditions for which the sample was largest $(\Delta f=0.10$ at $\mathrm{SOA}=500 \mathrm{~ms}$; Fig. $7 \mathrm{~B})$, using a color scale for the CSI values as in Figure 2. This analysis confirmed that SSA was strongest throughout the entire medial subdivision (MGM) followed by the caudal, medial and dorsal regions of the dorsal subdivision (MGD) (Fig. 7B). SSA was weaker in the ventral subdivision (MGV), being essentially non-existent in the center and somewhat greater in the periphery (Fig. 7B).

To quantify these observations, we performed a 3-Way ANOVA to look for significant effects and interactions between subdivisions and the conditions tested, for the $90 / 10 \%$ probability condition. The analysis of CSI across subdivisions (factors: subdivision $\mathrm{x} \Delta f \times \mathrm{SOA}$ ) indicated that all the factors had significant effects on the CSI $\left[F_{(2,211)}=89.6, F_{(2,211)}=28.4\right.$ and $F_{(3,211)}=7.6$, respectively; $p<0.001$ in all cases]. Post hoc comparisons (Tukey's HSD, $p<0.05)$ confirmed that the average CSI in the MGV (0.01) was not different from zero and was significantly smaller than that in the MGM and in the MGD (0.52 and 0.17, respectively); SSA in the MGM was significantly larger than in the MGD as well. CSI was significantly dependent on $\Delta f$, and decreased monotonically with $\Delta f$ (mean CSI $0.39,0.25$ and 0.07 for $\Delta f=0.37, \Delta f=0.1$ and $\Delta f=0.04$, respectively; all significantly larger than 0 , and all pairwise differences significant). SSA depended significantly on the SOA and was smaller for the largest SOA (2000 ms; mean 0.06) than for the other SOAs $(0.25,0.34$ and 0.29 for $\mathrm{SOA}=500 \mathrm{~ms}, 250 \mathrm{~ms}$ and $125 \mathrm{~ms}$ respectively); SSA levels at the three faster rates were not significantly different from each other.

Next we tested for interactions between the different factors. In this analysis the data corresponding to $\mathrm{SOA}=2000 \mathrm{~ms}$ were removed because this condition was not tested in the MGV subdivision at all. The main effects of subdivision and $\Delta f$ were similar to the previous analysis (both the order and the significance of the pairwise comparisons were preserved in the presence of possible interactions). SOA had a non-significant main effect $\left[F_{(2,182)}=2.6 ; p=0.08\right]$. This was not surprising given the finding that only the $\mathrm{SOA}=2000 \mathrm{~ms}$ condition had significantly different SSA from the other SOAs. The only significant interaction was between subdivision and $\Delta f\left[F_{(4,182)}=3.97 ; p<0.01\right]$. Post hoc comparisons (Tukey's HSD) revealed that in the MGV the average CSI at all $\Delta \mathrm{fs}$ were not significantly different from 0 and from each other $(0.11,0.07$ and 0.02 for $\Delta f=0.37,0.1$ and 0.04 respectively); In the MGD the mean CSI at $\Delta f=0.04$ was not significantly different from 0 (0.005), but at the other $\Delta f \mathrm{~s}$ was larger than 0 ( 0.36 and 0.23 for $\Delta f=0.37$ and 0.10 , respectively); in the MGM the mean CSI at all three $\Delta f \mathrm{~s}$ were significantly larger than $0(0.79$, 0.61 and 0.29 for $\Delta f=0.37,0.1$ and 0.04 respectively). Furthermore, in both MGD and MGM, the effects at $\Delta f=0.04$ were significantly smaller than at the other two $\Delta f \mathrm{~s}$; the effect at $\Delta f=0.37$ was larger than at $\Delta f=0.1$, but the two were not significantly different from each other in any subdivision.

\section{SSA within MGB subdivisions}

The previous analysis is conservative, as it did not account for a possible effect of neuron on $\Delta f$ and SOA: CSI values for the same neuron under different conditions tended to be correlated. To analyze the effect of neuron on SSA we performed an N-Way ANOVA with a nested design (introducing units within subdivi- 

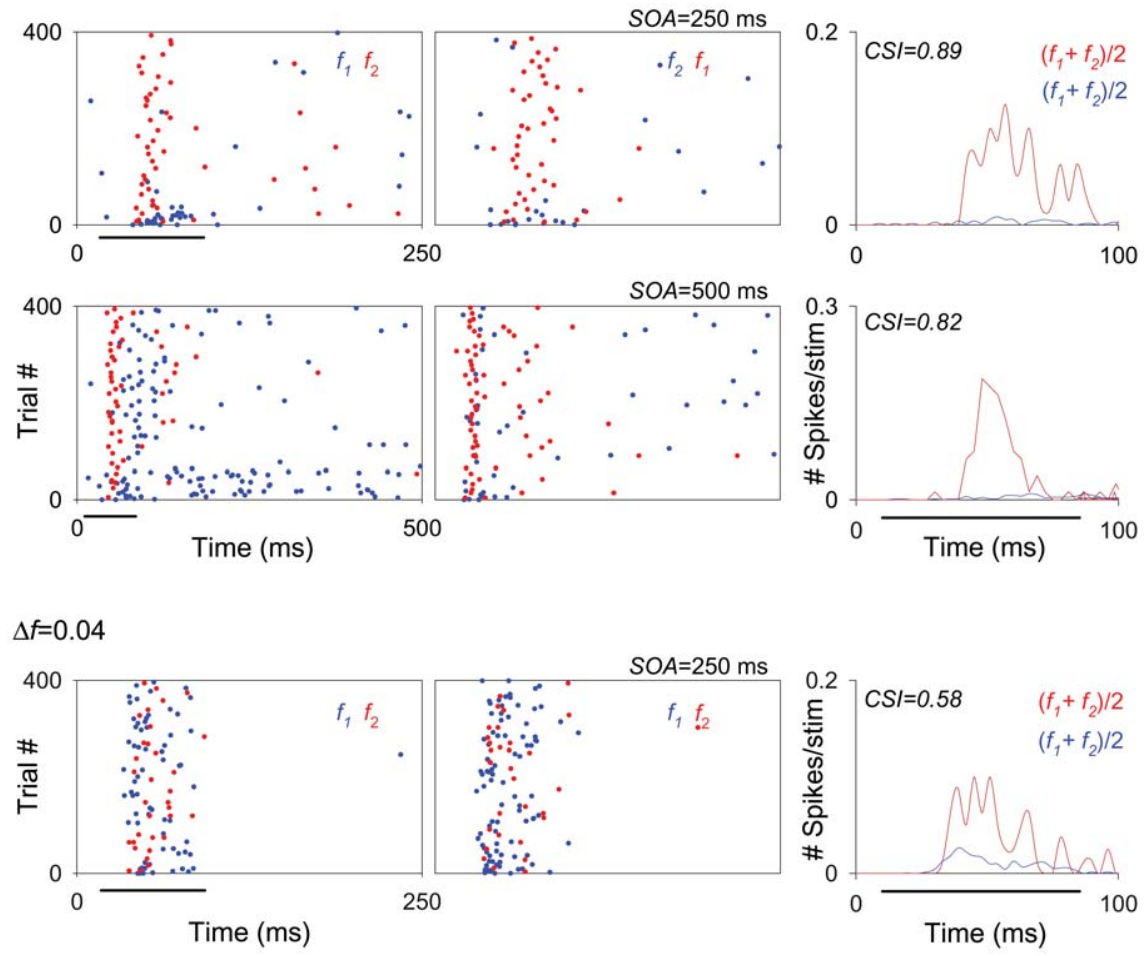

Figure 6. Some MGB neurons can discriminate between two very close frequencies. Example of sustained responses recorded from a neuron in the MGD, exhibiting high levels of SSA when tested at two closely spaced $\Delta f \mathrm{fs}(0.10$, first and second rows; 0.04 , third row). This neuron had a reduced but still high degree of adaptation for the smallest $\Delta f$ tested $(0.04)$, revealing its ability to discriminate between two very close frequencies. Details of dot rasters and PSTHs are the same as in figure 4. doi:10.1371/journal.pone.0014071.g006

sions). This analysis demonstrated a strong effect of neuron on the variation of $\operatorname{SSA}\left(F_{(73,138)}=5.26 ; p<0.0001\right)$.

To look at the effects of neuron, $\Delta f$, and SOA on SSA within subdivisions, we performed 3-Way ANOVAs for each subdivision separately, with the neurons as a random factor. This analysis demonstrated a significant effect of neurons in each subdivision separately $\left[F_{(21,39)}=2.75 ; p<0.01 ; F_{(28,34)}=14.92 ; p<0.001\right.$; and $F_{(24,56)}=3.10 ; p<0.001$, for the MGV, MGD and MGM respectively]. Within subdivisions, after controlling for neuron, the effect of $\Delta f$ was not significant in the ventral and dorsal subdivisions $\left[F_{(2,21)}=2.06 ; p=0.1\right.$ and $F_{(2,34)}=1.69 ; p=0.2$, respectively], but was significant in the medial subdivision $\left[F_{(2,56)}=5.06 ; p<0.01\right]$. These results are consistent with the analysis of the interactions between $\Delta f$ and subdivision presented above, which showed that the effect of $\Delta f$ was more pronounced in the MGM, weaker in the MGD and absent in the MGV. Most importantly, the analysis within subdivisions reveals a strong effect of SOA. CSI had a monotonically-inverse relationship with SOA in all three subdivions $\left[F_{(2,39)}=5.49 ; p<0.01 ; F_{(3,34)}=21.78\right.$; $p<0.001$; and $F_{(3,56)}=10.47 ; p<0.001$, for the MGV, MGD and MGM respectively].

Post hoc comparisons showed that in the MGV, SSA at the shortest SOA $(125 \mathrm{~ms})$ was significantly larger than at $\mathrm{SOA}=250 \mathrm{~ms}$; the other comparisons were not significant. Figure 8 shows an example of a neuron, localized to the MGV, that exhibited SSA at SOA $=125$ (CSI $=0.34$; first row) but not at $\mathrm{SOA}=250 \mathrm{~ms} \quad(\mathrm{CSI}=0.03 ;$ not shown $)$ or $\mathrm{SOA}=500 \mathrm{~ms}$ (CSI $=0.03$; second row).

In the MGD, as in the MGV, SSA at SOA of $125 \mathrm{~ms}$ was significantly larger than at $250 \mathrm{~ms}$. In the MGM, on the other hand, there was no significant difference between SOAs of 125, 250 and $500 \mathrm{~ms}$. Figure 4 shows an example of a neuron, localized to the MGM, that exhibited the same degree of adaptation for all of these different SOAs (first, second and third rows; 125, 250 and $500 \mathrm{~ms}$, respectively).

In the MGD and the MGM, SSA at the longest SOA (2000 ms) was significantly reduced with respect to the other SOAs. Figure 9 shows an example of a neuron, localized to the MGM, that showed reduced CSI at the longest SOA (second row in A and B) compared to shorter SOAs (first row in A and B), for two different $\Delta f \mathrm{~s}(0.37$ and 0.10$)$.

\section{Time course of SSA}

In order to study the dynamics of SSA in the population of MGB neurons, we calculated the average population firing rate versus trial number, for the two SOA conditions that showed the highest levels of adaptation (SOA = 250 and $500 \mathrm{~ms}$ ), and for which we collected the most data (Figure 10). We analyzed separately the non-adapting neurons $(\mathrm{CSI} \leq 0.18)$ and the adapting neurons $(\mathrm{CSI}>0.18)$ (Fig. $10 \mathrm{~A}$ and $\mathrm{B}$; left and right columns, respectively). In the initial trials, the average responses to the standard and deviant stimuli were similar (Fig. 10). The adapting neurons maintained or only slightly reduced their response to the deviant stimulus through the trials, while the response to the standard declined more strongly after the first few trials (Figs. 10; right column). The responses of non-adapting neurons to the standard also showed some decrement after the first trials, especially for the $\Delta f=0.37$ conditions (Fig. 10; left column), but this decrement was much smaller than that of the adapting neurons. As a consequence, non-adapting neurons maintained a 


\section{A}
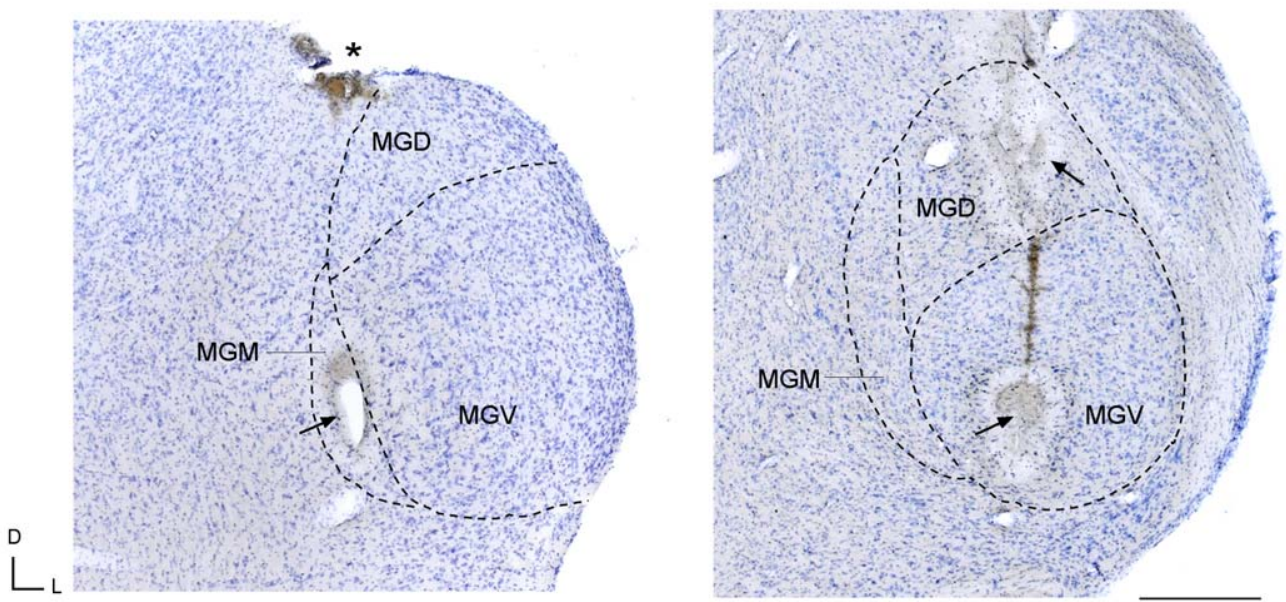

B
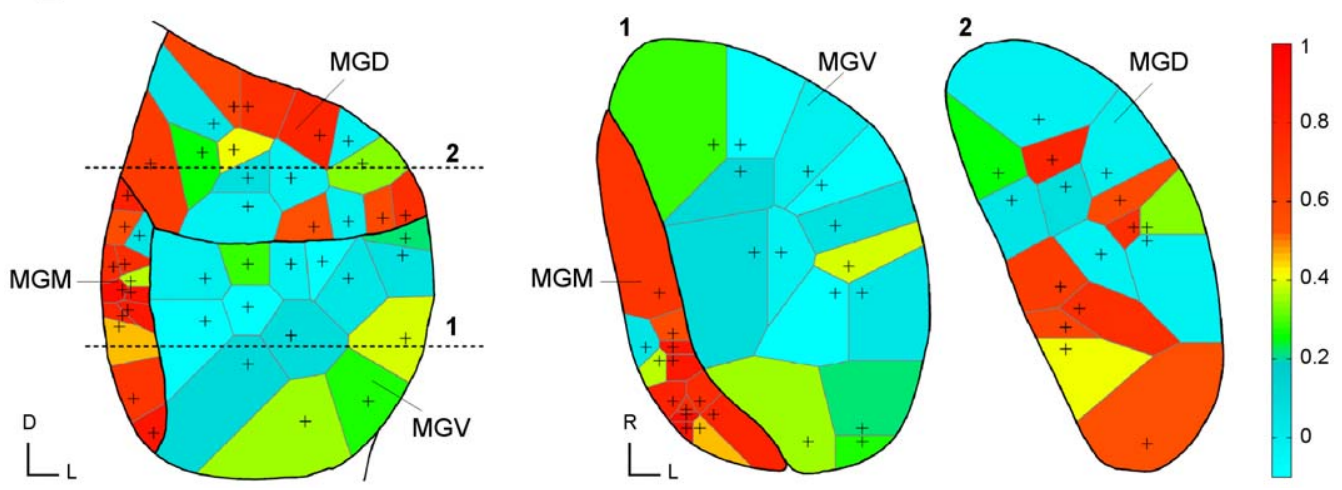

Figure 7. Location of recorded neurons and topographical organization of SSA across the MGB. (A) Nissl stained sections showing the MGB in the transverse plane. On the left (caudal), arrows indicate the electrolytic lesion in the MGM marking the recording site of the neuron shown in figure 9. Asterisk indicates another lesion for reference. On the right (rostral), arrows indicate an electrolytic lesion in the MGD and another one in the MGV, marking the recording site of the neuron shown in figure 8. Asterisk shows the recording track. $\mathrm{D}, \mathrm{dorsal} ; \mathrm{L}$, lateral; Calibration bar $=$ $500 \mu \mathrm{m}$. (B) Topographical organization of SSA within the MGB subdivisions, for the $\Delta f=0.10$ at SOA $=500$ ms condition. The center of tessellated polygons in the maps represents the sites at which the neurons were recorded. Each polygon was colored according to the CSI value of the neuron recorded at that site. The bar on the right represents the color scale used for the CSI range. Both the transverse projection (on left) and the horizontal projections through the MGV/MGM (section 1) and MGD (section 2) show that SSA was strongest throughout the entire MGM followed by the caudal, medial and dorsal regions of the MGD. SSA was very weak in the center of the MGV, but somewhat greater in its periphery. doi:10.1371/journal.pone.0014071.g007

higher firing rate to the standard than the adapting neurons across the trials, for all conditions (Fig. 10). We then fitted the responses to the standard with an exponential decay regression model $\left[f=a^{*} \exp (-\right.$ $\left.\left.b^{*} x\right)\right]$ and a polynomial inverse first order regression model $\left[f=y_{0}+(a / x)\right]$. The polynomial inverse first order model was the one that provided the best fit to the responses to the standard across trials, for all conditions. A high proportion of the adaptation to the standard by the adapting neurons was explained by this model, for the majority of conditions $\left(\mathrm{SOA}=250 \mathrm{~ms}: r^{2}=0.68\right.$ and 0.64 , at $\Delta f=0.37$ and 0.10 , respectively; SOA $=500 \mathrm{~ms}: r^{2}=0.47$ at both $\Delta f \mathrm{~s} ; p<0.001$ for all conditions; Fig. $10 \mathrm{~A}$ and $\mathrm{B}$, respectively; right column, first and second rows). For the smallest $\Delta f(0.04)$ the variance explained by the model was reduced $\left(r^{2}=0.24,0.20\right.$ at $\mathrm{SOA}=250$ and $500 \mathrm{~ms}$, respectively; $p<0.001$ for both conditions; Fig. 10, right column, third row). For the non-adapting neurons, the variance explained by the model was very low for all conditions $\left(\mathrm{SOA}=250 \mathrm{~ms}: r^{2}=0.04,0.12\right.$ and 0.1 , for $\Delta f=0.37,0.1$ and 0.04 , respectively; $\mathrm{SOA}=500 \mathrm{~ms}: r^{2}=0.14,0.05$ and 0.12 , for $\Delta f=0.37$,
0.1 and 0.04 , respectively; $p<0.001$ for all conditions; Fig. 10, left column). The smaller amount of variance explained by the regression model in these conditions presumably reflects the minor amount of adaptation of the non-adapting neurons.

\section{SSA in relation to discharge patterns and latencies}

Over half of the neurons that we recorded from the MGB had onset responses to auditory stimuli $(53 \%$; 49/93, e.g., Figs. 4, 8 and 9) while $24 \%$ had sustained responses (22/93, e.g., Fig. 6 ; defined as neurons that responded for $50 \mathrm{~ms}$ or more [23,25], in response to a $75 \mathrm{~ms}$ stimulus). In addition, some units $(10 \% ; 9 / 93)$ had two different response components: a brief onset burst at a relatively short latency (10-30 ms) followed by a long-duration burst at a much longer latency $(>115 \mathrm{~ms})$. Both response components were tuned to the same frequency range, but were clearly segregated in time. We refer to these units as on-late units. Fig. 11A shows an example of one of these units, recorded from the MGD and exhibiting SSA. A small percentage of neurons had offset 


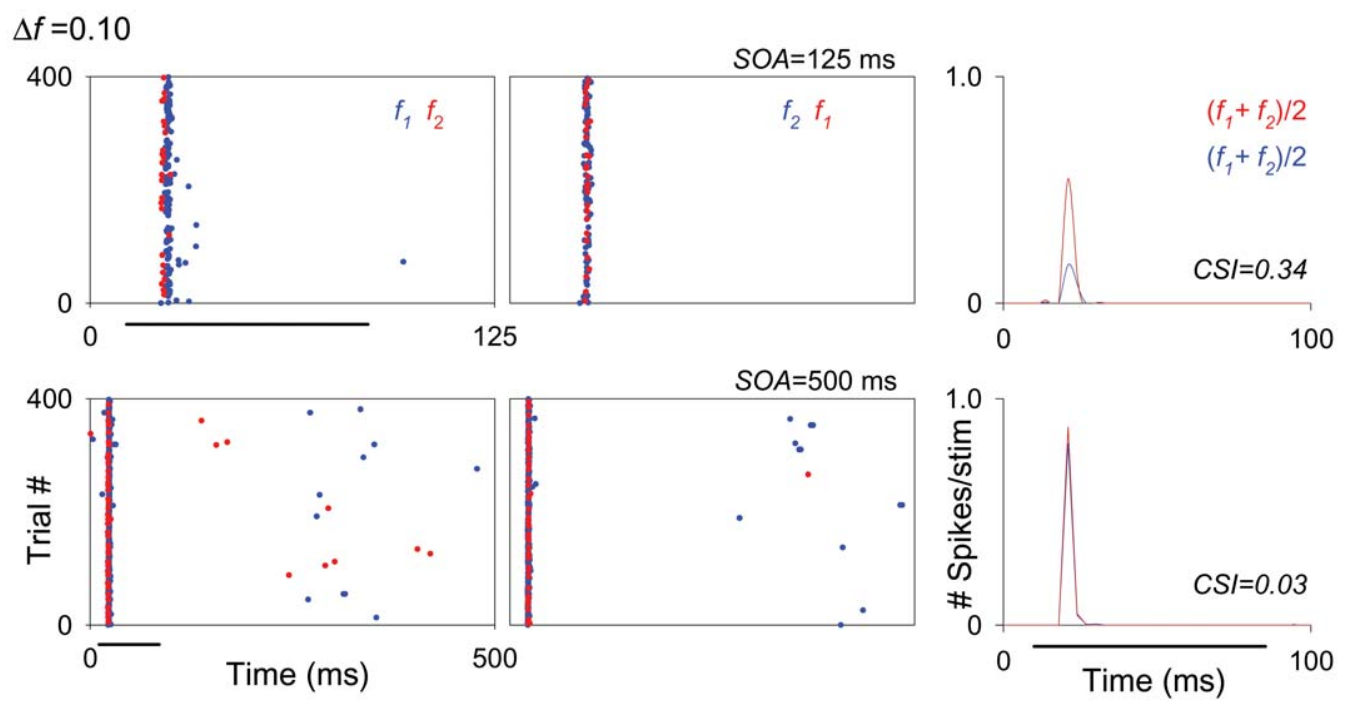

Figure 8. High repetition rates and large $\Delta$ fs can elicit SSA in some MGV neurons. Example of an onset neuron from the MGV tested at two different SOAs (500 and $125 \mathrm{~ms}$ ) for the same $\Delta f(0.37)$. This neuron did not show SSA for the longest SOA tested (500 ms, second row) but did show some adaptation at the shortest SOA (125 ms, first row). Details of dot rasters and PSTHs are the same as in figure 4 . The location of this neuron is shown in figure $7 \mathrm{~A}$.

doi:10.1371/journal.pone.0014071.g008

responses $(8 \% ; 7 / 93)$. Figure $11 \mathrm{~B}$ shows an example of one of these units, recorded from the MGV, also exhibiting SSA. Finally, some units $(2 \% ; 2 / 93)$ had on-off responses.

A high percentage of the units recorded $(56 \% ; 52 / 93)$ exhibited SSA for at least one of the two largest $\Delta f_{\mathrm{s}}(0.37$ and 0.10$)$ at one of the intermediate SOAs $(250$ and $500 \mathrm{~ms})$. Of these units, the majority were onset responders $(73 \% ; 38 / 52)$, followed by on-late responders $(12 \% ; 6 / 52)$, and a minority of sustained, long latency and offset responders $(6,6$ and 4\%; 3,3 and 2/52, respectively). Of the non-adapting neurons $(44 \% ; 41 / 93)$, the majority were sustained responders $(44 \% ; 18 / 41)$, followed by onset responders $(24 \% ; 10 /$ 41 ), and by smaller percentages of offset, on-late, long latency and on-off responders $(12,7.3,7.3,5 \% ; 5,3,3,2 / 41$, respectively). The distributions of unit types among the adapting and non-adapting neurons was significantly different $\left(\chi^{2}=22, \mathrm{df}=2, p<0.001\right)$.

To analyze the relationship between SSA and response latency, we plotted the mean first-spike latencies to the standard and deviant stimuli for all neurons under all conditions tested to determine whether their means differed (Fig. 12A). For the on-late neurons, we calculated separately the latency of their onset component $(<115 \mathrm{~ms})$ and the latency of their long latency component $(>115 \mathrm{~ms})$. For this reason, 16 out of the 388 data points in figure $12 \mathrm{~A}$ correspond to the long latency components of these neurons. The latency of the responses evoked by the deviant was significantly shorter on average than that evoked by the standard $(42.9$ and $45.7 \mathrm{~ms}$, respectively; paired t-test: $\mathrm{t}=5.79$, d.f. $=387, \mathrm{p}<0.001)$. Figure 13 shows an example of a neuron that exhibited a much shorter latency to the deviant than to the standard stimulus. For this neuron, the mean first spike latency of the response to the deviant was on average $15.1 \mathrm{~ms}$ shorter than that to the standard stimulus for an SOA $=250(26 \pm 0.4$ and $41.1 \pm 1.6 \mathrm{~ms}$; average of the mean first-spike latency for $\mathrm{f}_{1}$ and $\mathrm{f}_{2}$ when deviant and standard, respectively; Fig. 13); and 7.6 ms shorter for an $\mathrm{SOA}=500 \mathrm{~ms}(24.7 \pm 1.1$ and $32.3 \pm 1.2 \mathrm{~ms}$; average of the mean first-spike latency for $\mathrm{f}_{1}$ and $\mathrm{f}_{2}$ when deviant and standard, respectively; not shown). As would be expected, for this same neuron, the latency of the response to the first stimulus presentation of the set was similar for both stimuli $(24 \pm 0.7$ and $23.5 \pm 0.3 \mathrm{~ms}$, average of the first-spike latency to the first stimulus presentation for all stimuli, at $\mathrm{SOA}=250$ and $500 \mathrm{~ms}$, respectively).
Figure 12A shows that the latencies of the MGB neurons were distributed over a broad range; to determine whether the latency of the neurons was related to the amount of adaptation that they exhibited, we plotted their mean first-spike latencies to the deviant versus their CSI (Fig. 12B). While most latencies were distributed similarly across all values of CSI (Fig. 12B), the shortest latencies of neurons with large CSIs tended to be somewhat longer than the shortest latencies of those neurons with small CSIs. To better visualize this issue, Fig. 12C displays only short-latency responses $(<40 \mathrm{~ms})$ to standards (left plot) and deviants (right plot) as a function of CSI. Although there was considerable overlap at all CSIs, the CSI did have a significant effect on the variation of the minimal latencies $(<25 \mathrm{~ms})$ for both standard and deviant stimuli [one-way ANOVA grouped by CSI: $F_{(11,171)}=3.64 ; p<0.001$; and $F_{(11,203)}=4.72 ; p<0.001$, for deviant and standard respectively]. The minimal latencies of neurons exhibiting high CSI values $(>0.5)$ were longer than those exhibiting lower CSI values, except for the most negative CSI values (Fig. 12E displays the $10 \%$ percentile of the minimum latency distribution at different ranges of CSI; standard, left plot; deviant, right plot).

\section{Discussion}

In this study, we demonstrated that a significant percentage of neurons in the MGB show adaptation of their responses to tones in a stimulus-specific manner. Neurons in the MGM exhibited the strongest adaptation followed by neurons in the MGD. On the other hand, SSA was absent in the MGV under most of the tested conditions, and was found there only for the shortest SOAs used here $(125-250 \mathrm{~ms})$. Thus, SSA is prominent in the non-lemniscal divisions of the auditory thalamus, but weak in the ventral, lemniscal, division.

The stimulation conditions that evoked the strongest SSA in MGB neurons were the two largest $\Delta f_{s}(0.37,0.10)$ at the intermediate SOAs (250 and $500 \mathrm{~ms}$ ). Under these conditions a high percentage of MGM and MGD neurons showed strong to extreme adaptation. Moreover, some neurons in these subdivisions showed SSA even when tested with the longest SOA (2000 ms) as well as the smallest $\Delta f(0.04)$. Our study thus revealed the ability of 

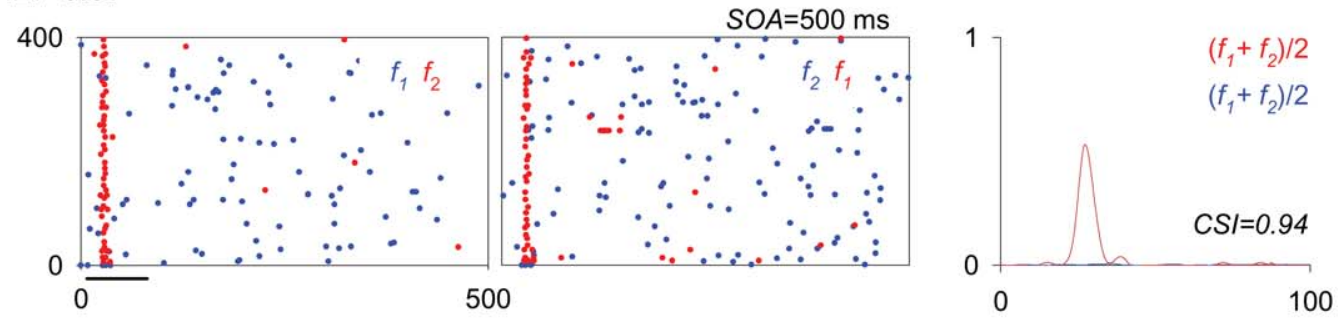

$\Delta f=0.10$
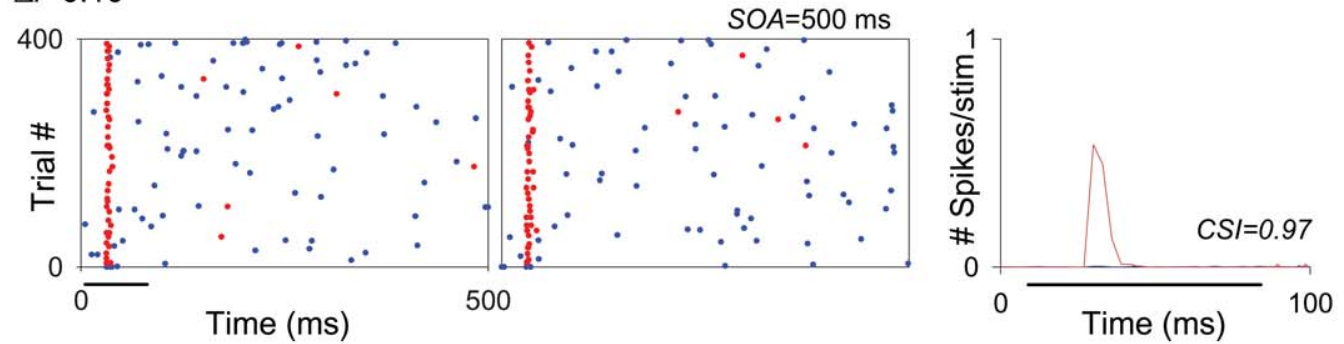

\section{B}
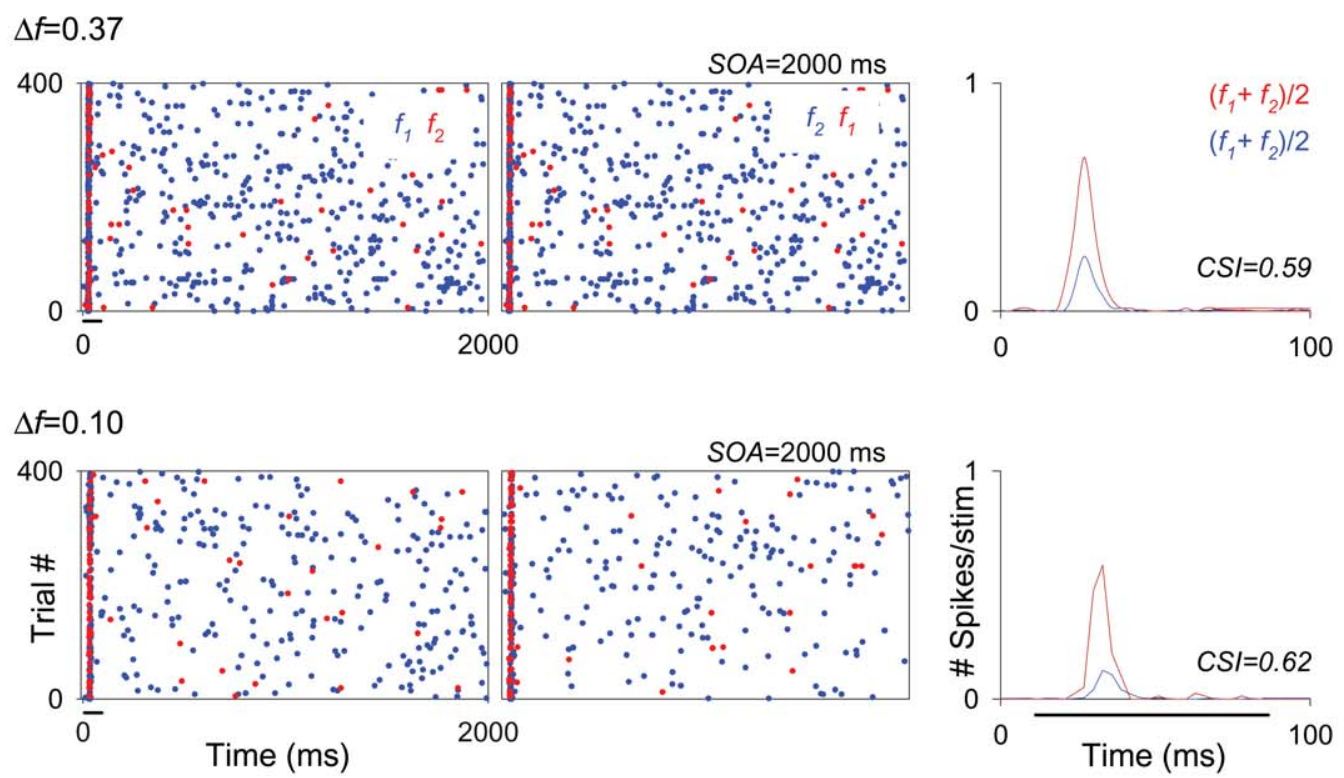

Figure 9. Low repetition rates elicit high SSA in some MGM neurons. Example of an onset neuron with spontaneous activity recorded in the MGM, showing strong adaptation under all of the conditions tested. (A) the neuron exhibited extreme adaptation when tested at the same SOA (500 ms) for two different $\triangle f \mathrm{~s}$ (0.37 and 0.10; first and second rows, respectively). (B) the neuron showed somewhat lower adaptation when tested at the longest SOA (2000 ms; same 4 fs as in A). In both $\mathrm{A}$ and B, the adaptation was similar for both $\triangle f$ conditions. Details of dot rasters and PSTHs are the same as in figure 4. The location of this neuron is shown in figure 7A. doi:10.1371/journal.pone.0014071.g009

these neurons to discriminate between two very close frequencies, both of which are well within their frequency response area. Such hyperacuity was demonstrated before in cat $\mathrm{AC}[10]$ and rat IC [4]. Our results together with those of others $[1,4,10,12,13]$ demonstrate the ubiquity of SSA in neurons throughout the auditory system, from the midbrain up to the auditory cortex.

\section{Comparison with previous studies}

Two recent studies tested SSA in MGB. Yu and colleagues [13] studied SSA in the rat MGB and thalamic reticular nucleus, a subdivision of the thalamus that lies outside the MGB. They demonstrated strong SSA in the thalamic reticular nucleus and weaker SSA in MGB. Anderson and colleagues [1] reported SSA in mouse MGB, but tested fewer conditions and showed weaker SSA than reported in the current study. We demonstrated that some neurons in the rat MGB exhibit very strong SSA even under the most extreme conditions tested (SOAs $=2000 \mathrm{~ms}$ or $\Delta \mathrm{f}=0.04)$. In fact, we found a few neurons in MGB with CSI values as high as those reported by $\mathrm{Yu}$ et al. [13] in the thalamic reticular nucleus, even when using SOAs twice as long. 
A

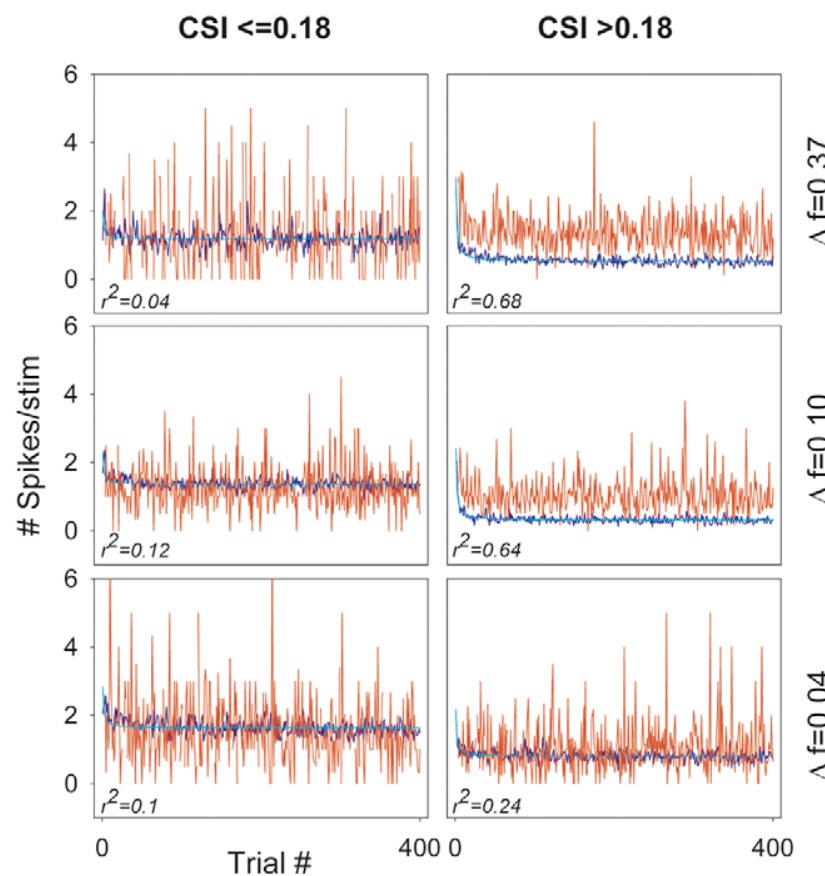

B

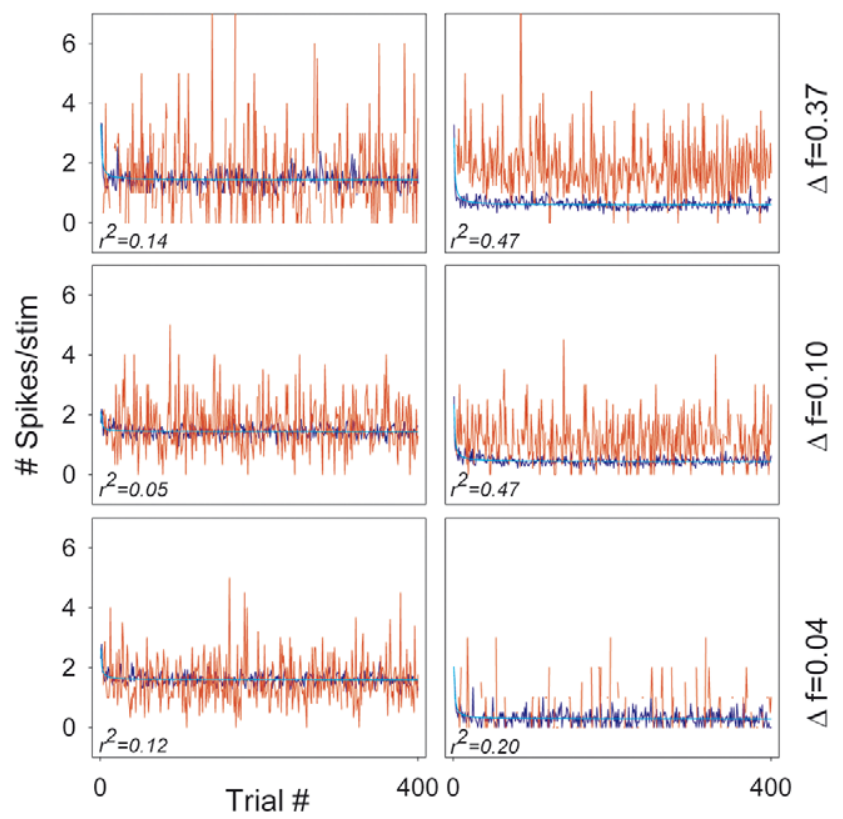

Figure 10. Time course of adaptation in the population of MGB neurons. Average population firing rate (spikes/stimulus) versus trial number for $\mathrm{SOA}=250 \mathrm{~ms}(\mathrm{~A})$ and $\mathrm{SOA}=500 \mathrm{~ms}(\mathrm{~B})$ and the different $\Delta f$ s tested, indicated to the right of each row. In both $A$ and $B$, the left columns correspond to non-adapting neurons $(\mathrm{CSI} \leq 0.18)$ and right columns to adapting neurons ( $\mathrm{CSI}>0.18$ ). The response of the adapting neurons to the standard stimulus strongly declined after the first trials. A high proportion of their adaptation to the stimulus was explained by a polynomial inverse regression model $[f=y 0+(a / x)]$, for the majority of conditions; the amount of variance explained was reduced for the smallest $\Delta f(0.04)(r 2=0.24,0.20$ in $\mathrm{A}$ and $\mathrm{B}$, respectively; $p<0.001$ for both conditions) and was very low for the non-adapting neurons, under all conditions.

doi:10.1371/journal.pone.0014071.g010
The parameter ranges over which SSA occurs in the rat MGB are similar to those in cat AC [10] and rat IC [4]. SSA in the rat IC was tested only for relatively short SOAs (up to $500 \mathrm{~ms}$ ), so we cannot compare the IC with the MGB for the largest SOA. However, our MGB results $(\mathrm{SOA}=2000 \mathrm{~ms}$, inter-tone duration $>1900 \mathrm{~ms})$ can be compared with those from the cat AC study (SOA $=2000 \mathrm{~ms}$, inter-tone duration $>1700 \mathrm{~ms}$ ). A SOA of $2000 \mathrm{~ms}$ corresponds to the most extreme condition for which Ulanovsky and colleagues [10] showed single units exhibiting SSA in Al (CSI $\approx 0.3$ ). We found higher values of SSA for this condition in the MGB (up to CSI = 0.7) than the previous study in the AG, but only outside the MGV. The $\mathrm{MGV}$ receives input from the central nucleus of the $\mathrm{IC}$ and is the main source of ascending input to A1 [28-31]. In this context, it is worth mentioning that SSA found in the central nucleus of the IC [4] is only relatively large for the shortest SOA tested (125 ms). Thus, the MGB and IC data tightly links SSA in subcortical regions to the non-lemniscal pathway $[4,6]$.

CSI values reported in $\mathrm{Al}$ of the cat are far in excess of the values measured in cat MGB, presumably in the ventral division [10], or in rat MGV. Thus, our results suggest that Al is the first lemniscal station in which SSA is widespread and strong. SSA in Al may therefore express the combined result of the rather weak SSA found in MGV augmented by intracortical mechanisms [37] and possibly by the weaker (but still present) non-lemniscal input to A1, either directly from the MGM [38] or indirectly through feedback connections from higher auditory areas. For example, a recent study [39] has demonstrated that reversible thermal deactivation of $\mathrm{AAF}$ alters $\mathrm{Al}$ responses but $\mathrm{AAF}$ responses are not altered by Al deactivation. These authors suggest a unidirectional flow of information from the non-lemniscal to the lemniscal pathway. If so, the SSA observed in Al may be modulated by the influence of AAF [10].

Strongly adapting neurons in both the MGB and the IC [4,6] were mainly onset responders, with relatively short latencies $(<40 \mathrm{~ms})$ for both the standard and the deviant stimuli. Nevertheless, the shortest latencies of the neurons that showed strong adaptation for a certain condition in the MGB were significantly longer than those of weakly adapting neurons for a certain condition, to both the deviant and standard stimuli. These slightly longer latencies could simply reflect lower firing rates of the neurons showing strong adaptation for a given condition, as the mean first-spike latency can be affected by the response strength, or it could be due to additional neuronal processing, for example cortical modulation of these neurons [10]. This hypothesis needs to be addressed in future experiments, e.g., by reversibly inactivating the $\mathrm{AC}[40,41]$.

\section{SSA and sensory memory}

A neuron exhibiting SSA integrates information about recent stimulus history in order to respond more strongly to a rare stimulus. SSA therefore embodies a short-term memory trace that determines the response of the neuron to subsequent stimulation $[7,42,43]$. We demonstrated that a polynomial scale-invariant model explained a high proportion of MGB neurons' adaptation to the standard stimulus. Such a power law model may indicate that adaptation occurs over a range of time-scales [44,45], so that in contrast to exponential adaptation, activity more than a few time constants back, although deemphasized, is not discarded. Indeed, SSA in Al neurons appears to occur on several time scales concurrently, spanning many orders of magnitude, from hundreds of milliseconds to tens of seconds [11], paralleling the behaviour of large neuronal populations as recorded in human event-related potentials [46]. SSA was therefore proposed as a candidate neuronal mechanism for auditory sensory memory and deviance detection as reported in human MMN studies $[5,47,48]$. However, 


\section{A On-long latency neuron}
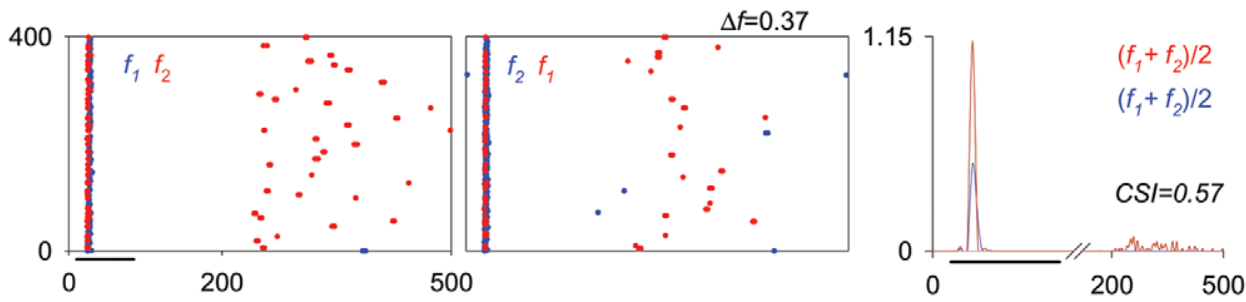

\section{B Off neuron}
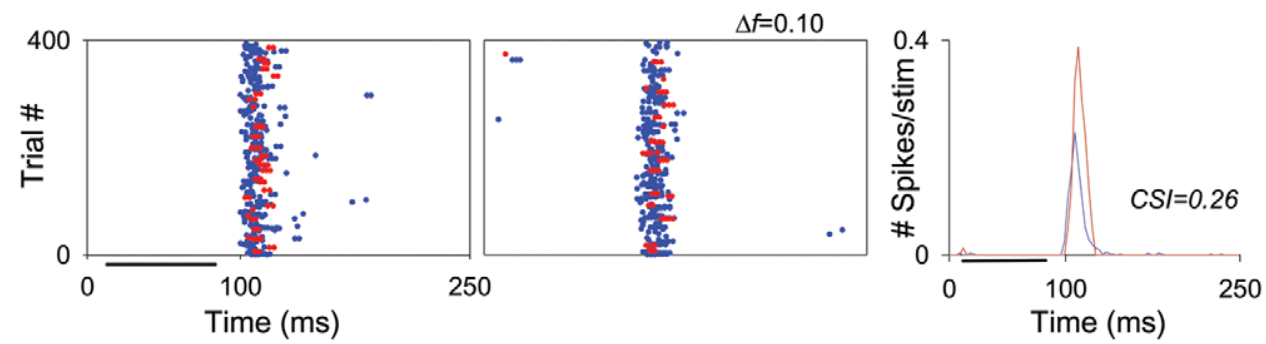

Figure 11. Some MGB neurons with on-late and off response types show adaptation. (A) Example of an on-late neuron in the MGD. This neuron responded with a brief onset burst at a relatively short latency $(14.8 \pm 0.4$ and $16 \pm 0.5 \mathrm{~ms}$; average of the mean first-spike latency for f1 and $\mathrm{f} 2$ when deviant and standard, respectively) followed by a long-duration burst at a much longer latency (245.8 \pm 7 ms; average of the mean firstspike latency for $\mathrm{f} 1$ and $\mathrm{f} 2$ when deviant). The neuron showed some adaptation in the onset burst but much stronger adaptation in the late burst $(\mathrm{CSI}=0.31$ and 0.98 , respectively; $\mathrm{CSI}=0.57$ for the entire response time window). Details of dot rasters and PSTHs are the same as in figure 4 . (B) Example of an offset neuron from the MGV that exhibited some adaptation $(\mathrm{CSI}=0.26)$. Details of dot rasters and PSTHs are the same as in figure 4. doi:10.1371/journal.pone.0014071.g011

the MMN component occurs at 100-250 ms after the onset of an acoustic change, while SSA occurs at much shorter latencies $[4,11]$. Indeed, a recent study based on neuronal recordings and evoked local field potentials (eLFP) in the awake rat found enhanced responses to deviants in eLFP but did not find the late deviant response component that would have been the equivalent to the human MMN [12]. Thus, SSA has been suggested to lie upstream of MMN generation. Recent studies in humans demonstrated that deviance detection can take place as early as $30 \mathrm{~ms}$ after stimulus onset, suggesting that early change detection processes occur upstream of MMN generation [49,50]. As in the animal models that have been studied, deviance detection in humans occurs at multiple levels in the auditory pathway, from the brainstem up to higher-order cortical areas [49,50].

Here, we demonstrate that the latencies of strongly adapting neurons in the MGB span a range between approximately $10 \mathrm{~ms}$ to $250 \mathrm{~ms}$ [51], covering the range of the different components of the MMN in humans $[47,49,50]$ and rats $[52,53]$. The majority of the strongly adapting neurons in the MGM subdivision had onset responses with short latencies. These neurons could be participants in a bottom-up stream of SSA [51]. However, some strongly adapting neurons in the MGB had very long onset latencies $(>150 \mathrm{~ms})$ and some neurons had two different components in their response, i.e., a short latency component $(<40 \mathrm{~ms})$ together with a long latency one $(>150 \mathrm{~ms})$. The timing of the long latency components of these neurons is similar to the range of the latencies of the MMN component of human ERPs ( $\approx 200 \mathrm{~ms} ;[14,47,54])$. This suggests that there might be some relationship between the SSA exhibited by this population of neurons and the MMN component. Our data and those of others who found evidence of MMN subcortically (reviewed in [19]) indicate that MMN may be generated by processes that include both bottom-up processing and corticothalamic feedback loops.

The presence of strong SSA in the auditory thalamus suggests that SSA is important for the type of processing performed there.
For example, the very strong SSA found in the MGM is consistent with its role as a major auditory input to the fear circuit in the amygdala $[24,55]$. The role of SSA expressed in IC and MGB in shaping SSA in Al is less clear, and it may well be that SSA in Al is generated at least in part de-novo. Nevertheless, the presence of strongly-adapting neurons in non-lemniscal divisions of the MGB may indicate the active role of these neurons in the generation, transformation or modulation of SSA expressed in other parts of the auditory system. Testing such a role would require future work.

\section{Materials and Methods}

\section{Surgical procedures}

Experiments were performed on 21 adult rats with body weights between 150-250 g. All experiments were carried out at the University of Salamanca with the approval of, and using methods conforming to the standards of, the University of Salamanca Animal Care Committee.

Surgical anaesthesia was induced and maintained with urethane (1.5 g/kg, i.p.), with supplementary doses $(0.5 \mathrm{~g} / \mathrm{kg}$, i.p.) given as needed. Urethane was selected as an anaesthetic because its effects on multiple aspects of neural activity, including inhibition and spontaneous firing, are known to be less than those of barbiturates and other anaesthetic drugs (e.g. [56]). The trachea was cannulated, and atropine sulphate $(0.05 \mathrm{mg} / \mathrm{kg}$, s.c.) was administered to reduce bronchial secretions. Body temperature was maintained at $38^{\circ} \mathrm{C} \pm 1^{\circ} \mathrm{C}$. Details of surgical preparation were as described elsewhere $[57,58]$. The animal was placed in a stereotaxic frame in which the ear bars were replaced by hollow specula that accommodated a sound delivery system.

\section{Acoustic stimuli and electrophysiological recording}

A craniotomy was performed to expose the cerebral cortex overlying the MGB. A tungsten electrode (1-2 M 2 ; [59]) was 
A

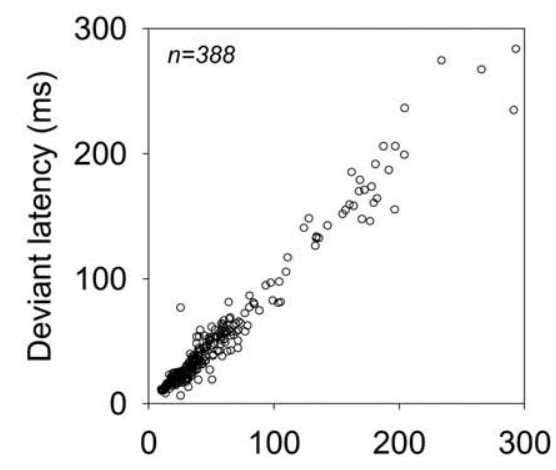

Standard latency (ms)
B
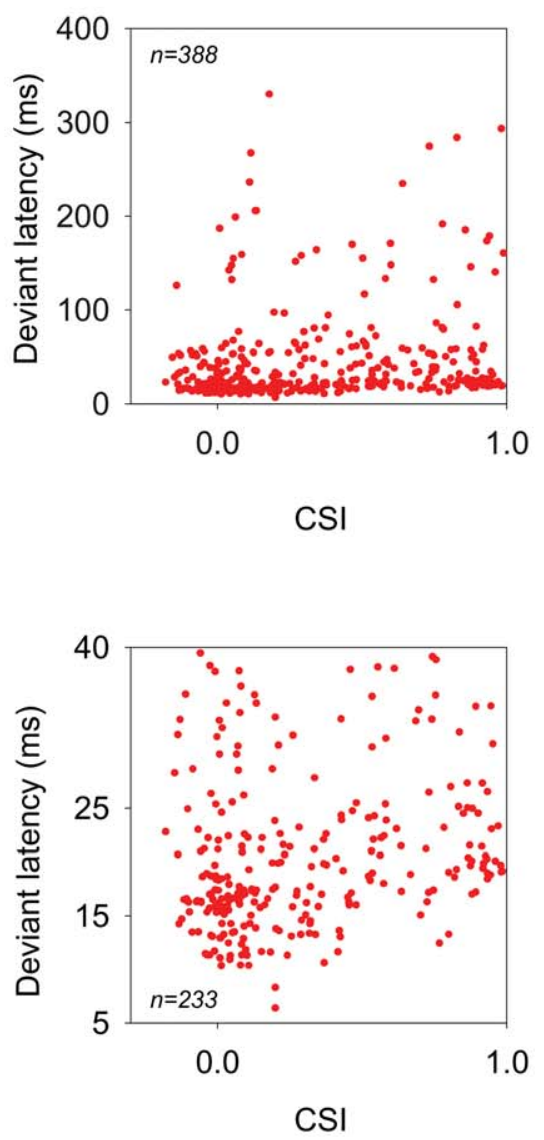

D
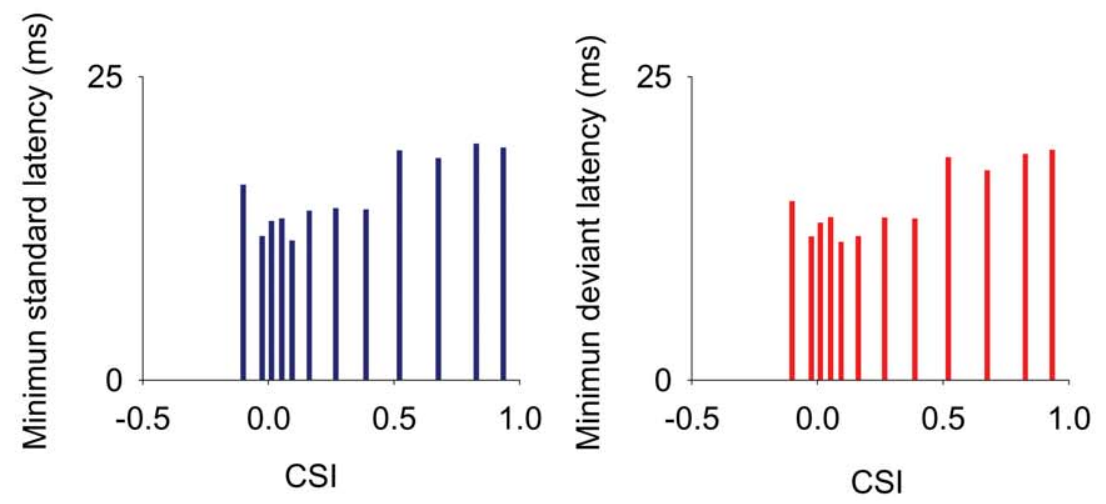

Figure 12. Response latencies in the MGB population of neurons. (A) Mean first-spike latencies to the deviant versus standard stimulus for the MGB population. Latencies to the deviant were on average significantly shorter than those to the standard stimulus (Mean $=42.9$ and $45.7 \mathrm{~ms}$, respectively; paired $t$-test: $t=5.79, n=388$, d.f $=387, p<0.001$ ). (B) Mean first-spike latencies to the deviant versus CSI. The shortest latencies of highly adapting neurons were longer than those of non-adapting neurons. (C) Short-latency responses $(<40 \mathrm{~ms})$ to standard (left plot) and deviant (right plot) versus CSI. (D) The 10th percentile of the minimum latency distribution for the standard (left plot) and deviant (right plot) at different ranges of CSI. The minimal latencies of neurons with high CSI values $(>0.5)$ were longer than those with lower CSI values, except for the most negative CSI values. doi:10.1371/journal.pone.0014071.g012

lowered through the cortex and used to record extracellular single unit responses. Neuron localization in the MGB was based on stereotaxic coordinates, physiological criteria of tonotopicity and response properties [23-25]. Subsequent histological verification was performed using electrolytic lesions $(5-10 \mu \mathrm{A}$ for $5-10 \mathrm{~s})$ to mark recording sites [60].

Stimuli were delivered through a sealed acoustic system $[61,62]$ using two electrostatic loudspeakers (TDT- EC1) driven by two
TDT-ED1 modules. Pure tone bursts were delivered to the contralateral ear under computer control using TDT System 2 (Tucker-Davis Technologies) hardware and custom software $[4,63,64]$. The output of the system at each ear was calibrated in situ using a 1/4" condenser microphone (Brüel and Kjær 4136, Nærum, Denmark) and a DI-2200 spectrum analyser (Diagnostic Instruments Ltd., Livingston, Scotland, UK). The maximum output of the TDT system was flat from $0.3-5 \mathrm{kHz}(\sim 100 \pm 7 \mathrm{~dB}$ 

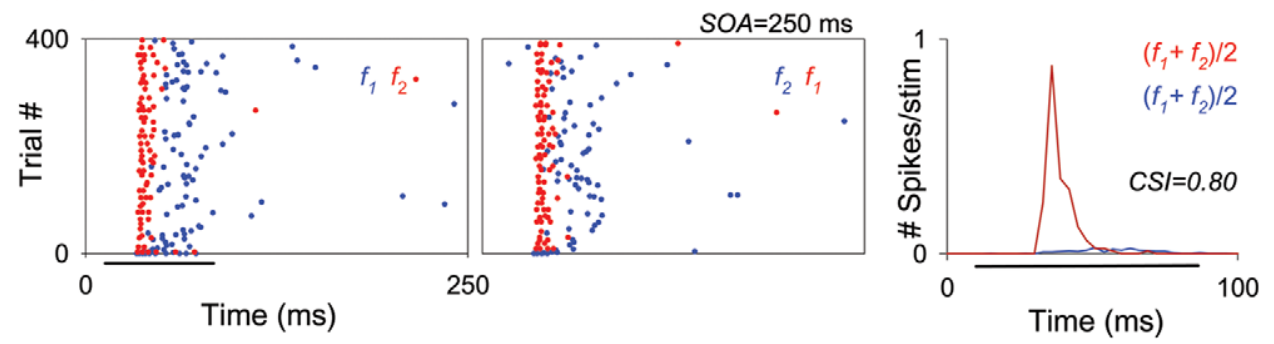

Figure 13. MGB neurons show shorter latencies to the deviant than to the standard stimulus. Example of an adapting neuron that responded with a much shorter latency to the deviant than to the standard stimulus ( $26 \pm 0.4$ and $41.1 \pm 1.6 \mathrm{~ms}$; average of the mean first-spike latency between $\mathrm{f} 1$ and $\mathrm{f} 2$ when deviant and standard, respectively), for a $\Delta f=0.10$ at SOA $=250$ ms condition. The latency of the response to the first stimulus presentation of the set was similar for both stimuli, it was even slightly shorter to the standard $(24.5 \pm 0.7$ and $23.5 \pm 0.2 \mathrm{~ms}$, average of the first-spike latency to the first stimulus presentation between $\mathrm{f} 1$ and $\mathrm{f} 2$, when deviant and standard, respectively). Details of dot rasters and PSTHs are the same as in figure 4.

doi:10.1371/journal.pone.0014071.g013

SPL) and from 5-40 kHz (90 $\pm 5 \mathrm{~dB}$ SPL). The highest frequency produced by this system was limited to $40 \mathrm{kHz}$. The second and third harmonic components in the signal were $40 \mathrm{~dB}$ or more below the level of the fundamental at the highest output level $[60,65]$.

Tones were $75 \mathrm{~ms}$ duration with a $5 \mathrm{~ms}$ rise/fall time. The electrode was advanced using a Burleigh microdrive. Action potentials were recorded with a BIOAMP amplifier (TDT), the 10X output of which was further amplified and bandpass-filtered (TDT PC1; $\mathrm{f}_{\mathrm{c}}, 500 \mathrm{~Hz}$ and $3 \mathrm{kHz}$ ) before passing through a spike discriminator (TDT SD1). Spike times were logged on a computer by feeding the output of the spike discriminator into an event timer (TDT ET1) synchronized to a timing generator (TDT TG6). Stimulus generation and on-line data visualization were controlled with custom software. Spike times were displayed as dot rasters ordered by the acoustic parameter varied during testing. Search stimuli were pure tones or noise bursts.

To the extent possible, the approximate frequency tuning of the cell was audiovisually determined. The minimum threshold and best frequency $(\mathrm{BF})$ of the cell were obtained by an automated procedure with 2-5 stimulus repetitions at each frequency and intensity step. The monaural frequency response area (FRA, e.g., Fig. 1), i.e., the combination of frequencies and intensities capable of evoking a response, was then obtained automatically using a randomized stimulus presentation paradigm and plotted using EXCEL, SIGMAPLOT and MATLAB software. The stimuli used to generate FRAs in single units were pure tones with a duration of $75 \mathrm{~ms}$. Frequency and intensity of the stimulus were varied randomly $(0-100 \mathrm{~dB}$ attenuation in 5 or $10 \mathrm{~dB}$ steps and in 25 frequency steps from $0.1-40$ to cover approximately $2-3$ octaves above and below the BF; $[60,65])$.

\section{Stimulus presentation paradigms}

For all neurons, stimuli were presented in an oddball paradigm similar to that used to record mismatch negativity responses in human studies [54] and more recently in the cat auditory cortex $[10,11]$ and rat inferior colliculus [4]. Briefly, we presented trains of two different pure tone stimuli $\left(\mathrm{f}_{1}\right.$ and $\left.\mathrm{f}_{2}\right)$, at a level of 10-40 dB above threshold. Both frequencies were within the excitatory frequency response area previously determined for the neuron (Fig. 1). We presented a train of 400 stimuli containing both frequencies in a pseudo-random order at a specific repetition rate. One frequency $\left(f_{1}\right)$ was presented as the standard (i.e., high probability within the sequence); interspersed randomly with the second frequency $\left(f_{2}\right)$ presented as the deviant (i.e., low probability within the sequence). Special care was taken to choose a frequency pair that elicited similar spike counts when presented individually, to ensure that all differences in response were solely due to the statistics of the stimulus ensemble (Fig. 1). The custom software allowed us to independently vary the probability of the deviant stimulus and the amount by which its frequency varied from that of the standard. After obtaining one data set, the relative probabilities of the two stimuli were reversed, with $f_{2}$ as the standard and $f_{1}$ as the deviant (total number of stimuli for the frequency pair, 800).

The same paradigm was repeated varying the probability of the standard/deviant stimuli $(90 / 10 \%$ and $70 / 30 \%)$, the stimulus onset asynchrony (SOA $=2000 \mathrm{~ms}, 500 \mathrm{~ms}, 250 \mathrm{~ms}$, and $125 \mathrm{~ms}$ ), and the frequency contrast between the standard and deviant. The frequency contrasts were chosen to be as close as possible to values that have been used in other studies to allow direct comparisons of the data $[4,10,11]$, i.e., $\Delta f=0.37,0.10$ and 0.04 ; where $\Delta f=\left(\mathrm{f}_{2}-\mathrm{f}_{1}\right) /\left(\mathrm{f}_{2} * \mathrm{f}_{1}\right)^{1 / 2}$ is the normalized frequency difference (Malmierca et al., 2009; Ulanovsky et al., 2003). These values correspond to frequency ratios of $0.526,0.141$ and 0.057 octaves, respectively. We quantified SSA as described previously [4,10,11]. The frequency-specific SSA index, $\operatorname{SI}\left(\mathrm{f}_{\mathrm{i}}\right)(\mathrm{i}=1$ or 2$)$, was calculated as $\mathrm{SI}\left(\mathrm{f}_{\mathrm{i}}\right)=\left[\mathrm{d}\left(\mathrm{f}_{\mathrm{i}}\right)-\mathrm{s}\left(\mathrm{f}_{\mathrm{i}}\right)\right] /\left[\mathrm{d}\left(\mathrm{f}_{\mathrm{i}}\right)+\mathrm{s}\left(\mathrm{f}_{\mathrm{i}}\right)\right]$ where $\mathrm{d}\left(\mathrm{f}_{\mathrm{i}}\right)$ and $\mathrm{s}\left(\mathrm{f}_{\mathrm{i}}\right)$ were responses (in spike counts/stimulus) to frequency $\mathrm{f}_{\mathrm{i}}$ when it was deviant or standard, respectively. The amount of SSA for both frequencies at each condition (Common SSA index, CSI) was calculated as CSI $=\left[\mathrm{d}\left(\mathrm{f}_{1}\right)+\mathrm{d}\left(\mathrm{f}_{2}\right)-\mathrm{s}\left(\mathrm{f}_{1}\right)-\mathrm{s}\left(\mathrm{f}_{2}\right)\right] /\left[\mathrm{d}\left(\mathrm{f}_{1}\right)+\mathrm{d}\left(\mathrm{f}_{2}\right)+\mathrm{s}\left(\mathrm{f}_{1}\right)+\mathrm{s}\left(\mathrm{f}_{2}\right)\right]$.

These indices reflect the extent to which the response to a tone, when standard, was smaller than the response to the same tone, when deviant. The indices range between -1 to +1 , being positive if the response to a tone, when deviant, was greater than the response to the same tone, when standard. To thoroughly quantify the conditions that elicited SSA in a given neuron, the indices were calculated for the different combination of conditions tested (probability ratios, frequency contrasts, and repetition rates). For each neuron, this resulted in a set of $\mathrm{SI}\left(\mathrm{f}_{\mathrm{i}}\right)$ and CSI values for all of the conditions that were tested.

To analyse SSA across MGB subdivisions, a fixed-effect 3-way ANOVA was performed (factors: subdivisions $\mathrm{x} \Delta f \mathrm{x}$ SOA), followed by Post hoc comparisons (Tukey's HSD, $p<0.05$ ). To analyse the effect of neuron on SSA the 3-way ANOVA was augmented into a nested design (neurons within subdivisions). To analyse the effects of neuron, $\Delta f$ and SOA on SSA within subdivisions, 3-Way ANOVAs were performed for each subdivision separately, with neurons considered as a random factor. All 
analyses were done using the statistical toolbox of Matlab (MathWorks).

\section{Histological verification of recording sites}

Each track was marked with electrolytic lesions for subsequent histological localization of the neurons recorded. At the end of most experiments (26 out of 34 ) the animal was given a lethal dose of sodium pentobarbital and perfused transcardially with phosphate buffered saline $\left(0.5 \% \mathrm{NaNO}_{3}\right.$ in $\left.\mathrm{PBS}\right)$ followed by fixative (a mixture of $1 \%$ paraformaldehyde and 1\% glutaraldehyde in rat Ringer's solution). After fixation and dissection, the brain tissue was cryoprotected in 30\% sucrose and sectioned on a freezing microtome in the transverse or sagittal planes into $40 \mu \mathrm{m}$-thick sections. Sections were Nissl stained with $0.1 \%$ cresyl violet to facilitate identification of cytoarchitectural boundaries [22]. Recording sites were marked on standard sections from a rat brain atlas [65] and units were assigned to one of the three main divisions (ventral, dorsal and medial) of the MGB [22]. The stained sections with the lesions were used to localize each track mediolaterally, dorsoventrally and rostrocaudally in the Paxinos atlas [66]. To determine the three main MGB subdivisions [20,22] cytoarchitectonic criteria, i.e., cell shape and size, Nissl staining patterns and cell packing density, were used. This information was complemented and confirmed by the stereotaxic coordinates used during the experiment to localize the MGB. After assigning a section to each track/lesion, the electrophysiological coordinates from each experiment and recording unit, i.e., beginning and end of the MGB, as well as the depth of the neuron, were used as

\section{References}

1. Anderson LA, Christianson GB, Linden JF (2009) Stimulus-specific adaptation occurs in the auditory thalamus. J Neurosci 29: 7359-7363.

2. Baeuerle P, Von Der Behrens W, Gaese B, Kossl M (2009) Stimulus-Specific Adaptation in the Auditory Thalamus of the Mongolian Gerbil. ARO abstr 33: 646.

3. Kraus N, McGee T, Littman T, Nicol T, King C (1994) Nonprimary auditory thalamic representation of acoustic change. J Neurophysiol 72: 1270-1277.

4. Malmierca MS, Cristaudo S, Perez-Gonzalez D, Covey E (2009) Stimulusspecific adaptation in the inferior colliculus of the anesthetized rat. J Neurosci 29: 5483-5493.

5. Nelken I, Ulanovsky $\mathrm{N}$ (2007) Mismatch negativity and stimulus-specific adaptation in animal models. Journal of Psycophysiology 214-223.

6. Perez-Gonzalez D, Malmierca MS, Covey E (2005) Novelty detector neurons in the mammalian auditory midbrain. Eur J Neurosci 22: 2879-2885.

7. Reches A, Gutfreund Y (2008) Stimulus-specific adaptations in the gaze control system of the barn owl. J Neurosci 28: 1523-1533.

8. Reches A, Gutfreund Y (2009) Auditory and multisensory responses in the tectofugal pathway of the barn owl. J Neurosci 29: 9602-9613.

9. Reches A, Netser S, Gutfreund Y (2010) Interactions between stimulus-specific adaptation and visual auditory integration in the forebrain of the barn owl. J Neurosci 30: 6991-6998.

10. Ulanovsky N, Las L, Nelken I (2003) Processing of low-probability sounds by cortical neurons. Nat Neurosci 6: 391-398.

11. Ulanovsky N, Las L, Farkas D, Nelken I (2004) Multiple time scales of adaptation in auditory cortex neurons. J Neurosci 24: 10440-10453.

12. von der Behrens W, Bauerle P, Kossl M, Gaese BH (2009) Correlating stimulusspecific adaptation of cortical neurons and local field potentials in the awake rat. J Neurosci 29: 13837-13849.

13. Yu XJ, Xu XX, He S, He J (2009) Change detection by thalamic reticular neurons. Nat Neurosci 12: 1165-1170.

14. Escera C, Alho K, Winkler I, Naatanen R (1998) Neural mechanisms of involuntary attention to acoustic novelty and change. J Cogn Neurosci 10: 590-604.

15. Escera C, Corral ML (2007) Role of mismatch negativity and novelty-P3 in involuntary auditory attention. Journal of Psychophysiology 21: 251-264.

16. Naatanen R, Michie PT (1979) Early selective-attention effects on the evoked potential: a critical review and reinterpretation. Biol Psychol 8: 81-136.

17. Naatanen R, Paavilainen P, Rinne T, Alho K (2007) The mismatch negativity $(\mathrm{MMN})$ in basic research of central auditory processing: a review. Clin Neurophysiol 118: 2544-2590.

18. Näätänen R, Gaillard AW, Mantysalo S (1978) Early selective-attention effect on evoked potential reinterpreted. Acta Psychol (Amst) 42: 313-329.

19. Winkler I, Denham SL, Nelken I (2009) Modeling the auditory scene: predictive regularity representations and perceptual objects. Trends Cogn Sci 13: 532-540. complementary references to localize each neuron within a track. Neurons localized at the border between subdivisions and those recorded in the animals that were not perfused were excluded from this analysis. Based on selected conditions for which a large number of tested neurons were localized, topographic maps of SSA were constructed using Voronoi Tessellations of the recording sites (e.g. [36]). Each polygon was coloured according to the CSI of the unit recorded at that site. The sections shown in figure $7 \mathrm{~A}$ were photographed at high resolution with a Zeiss Axioskop 40 microscope using a Zeiss AxioCam MRc 5 digital camera (Carl Zeiss, Oberkochen, Germany) and plan semi-apochromatic objective lenses $5 \times(\mathrm{NA} 0.15)$. The brightness and contrast of images were adjusted with Adobe Photoshop software (Adobe, San José, CA, USA).

\section{Acknowledgments}

We thank David Perez-Gonzalez and Jorge Martin for their assistance on figure 2 and $7 \mathrm{~B}$, Enrique Saldaña for his help in taking the photomicrographs on Fig. 7A and Ignacio Plaza for his help with histological processing. We also thank 3 anonymous reviewers for their critical and constructive criticisms.

\section{Author Contributions}

Conceived and designed the experiments: EC MSM. Performed the experiments: FMA. Analyzed the data: FMA IN. Contributed reagents/ materials/analysis tools: FMA IN EC. Wrote the paper: FMA MSM. Supervised the project: MSM. Gave conceptual advice: IN EC.

20. Clerici WJ, Coleman JR (1990) Anatomy of the rat medial geniculate body: I. Cytoarchitecture, myeloarchitecture, and neocortical connectivity. J Comp Neurol 297: 14-31.

21. Malmierca MS (2003) The structure and physiology of the rat auditory system: an overview. Int Rev Neurobiol 56: 147-211.

22. Winer JA, Kelly JB, Larue DT (1999) Neural architecture of the rat medial geniculate body. Hear Res 130: 19-41.

23. Edeline JM, Manunta Y, Nodal FR, Bajo VM (1999) Do auditory responses recorded from awake animals reflect the anatomical parcellation of the auditory thalamus? Hear Res 131: 135-152.

24. Bordi F, LeDoux JE (1994) Response properties of single units in areas of rat auditory thalamus that project to the amygdala. II. Cells receiving convergent auditory and somatosensory inputs and cells antidromically activated by amygdala stimulation. Exp Brain Res 98: 275-286.

25. Bordi F, LeDoux JE (1994) Response properties of single units in areas of rat auditory thalamus that project to the amygdala. I. Acoustic discharge patterns and frequency receptive fields. Exp Brain Res 98: 261-274.

26. Oliver DL, Ostapoff EM, Beckius GE (1999) Direct innervation of identified tectothalamic neurons in the inferior colliculus by axons from the cochlear nucleus. Neuroscience 93: 643-658.

27. Peruzzi D, Bartlett E, Smith PH, Oliver DL (1997) A monosynaptic GABAergic input from the inferior colliculus to the medial geniculate body in rat. J Neurosci 17: $3766-3777$.

28. He J (2003) Corticofugal modulation of the auditory thalamus. Exp Brain Res 153: 579-590.

29. He J (2003) Corticofugal modulation on both ON and OFF responses in the nonlemniscal auditory thalamus of the guinea pig. J Neurophysiol 89: 367-381.

30. Lee CG, Winer JA (2005) Principles governing auditory cortex connections. Cereb Cortex 15: 1804-1814.

31. Lee CC, Winer JA (2008) Connections of cat auditory cortex: I. Thalamocortical system. J Comp Neurol 507: 1879-1900.

32. Winer JA, Diehl JJ, Larue DT (2001) Projections of auditory cortex to the medial geniculate body of the cat. J Comp Neurol 430: 27-55.

33. Antunes F, Covey E, Malmierca MS (2009a) Contribution of the thalamus to detection of novel sounds: is there stimulus-specific adaptation in the medial geniculate body of the rat? ARO abstr 32: 35-36.

34. Antunes F, Covey E, Malmierca MS (2009b) Stimulus-specific adaptation in the medial geniculate body of the rat. Frontiers in Human Neuroscience, Conference Abstract: MMN 09 Fifth Conference on Mismatch Negativity (MMN) and its Clinical and Scientific Applications. doi: 10.3389/conf.neuro.09.2009.05.144.

35. Antunes F, Covey E, Malmierca MS (2010) Is there stimulus-specific adaptation in the auditory thalamus? In The Neurophysiological Bases of Auditory Perception ed by E.A. Lopez-Poveda, AR Palmer, R. Meddis. pp 535-544. 
36. Kilgard MP, Merzenich MM (1999) Distributed representation of spectral and temporal information in rat primary auditory cortex. Hear Res 134: 16-28.

37. Szymanski FD, Garcia-Lazaro JA, Schnupp JW (2009) Current source density profiles of stimulus-specific adaptation in rat auditory cortex. J Neurophysiol 102: $1483-1490$.

38. Kimura A, Donishi T, Sakoda T, Hazama M, Tamai Y (2003) Auditory thalamic nuclei projections to the temporal cortex in the rat. Neuroscience 117: 1003-1016.

39. Carrasco A, Lomber SG (2009) Differential modulatory influences between primary auditory cortex and the anterior auditory field. J Neurosci 29: 8350-8362.

40. Lomber SG (1999) The advantages and limitations of permanent or reversible deactivation techniques in the assessment of neural function. J Neurosci Methods 86: 109-117.

41. Lomber SG, Malhotra S (2008) Double dissociation of 'what' and 'where' processing in auditory cortex. Nat Neurosci 11: 609-616.

42. Jaaskelainen IP, Ahveninen J, Belliveau JW, Raij T, Sams M (2007) Short-term plasticity in auditory cognition. Trends Neurosci 30: 653-661.

43. Nelken I, Fishbach A, Las L, Ulanovsky N, Farkas D (2003) Primary auditory cortex of cats: feature detection or something else? Biol Cybern 89: 397-406.

44. Drew PJ, Abbott LF (2006) Extending the effects of spike-timing-dependent plasticity to behavioral timescales. Proc Natl Acad Sci U S A 103: 8876-8881.

45. Drew PJ, Abbott LF (2006) Models and properties of power-law adaptation in neural systems. J Neurophysiol 96: 826-833.

46. Costa-Faidella J, Grimm S, Slabu L, Díaz-Santaella F, Escera C (2010) Multiple time scales of adaptation in the auditory system as revealed by human evoked potentials. Psychophysiology. In press.

47. Haenschel C, Vernon DJ, Dwivedi P, Gruzelier JH, Baldeweg T (2005) Eventrelated brain potential correlates of human auditory sensory memory-trace formation. J Neurosci 25: 10494-10501.

48. Jaaskelainen IP, Ahveninen J, Bonmassar G, Dale AM, Ilmoniemi RJ, et al. (2004) Human posterior auditory cortex gates novel sounds to consciousness. Proc Natl Acad Sci U S A 101: 6809-6814.

49. Grimm S, Escera C, Slabu L, Costa-Faidella J (2010) Electrophysiological evidence for the hierarchical organization of auditory change detection in the human brain. Psychophysiology, in press;doi: 10.1111.j.1469-8986.2010.01073.x.

50. Slabu L, Escera C, Grimm S, Costa-Faidella J (2010) Early change detection in humans as revealed by auditory brainstem and middle-latency evoked potentials. Eur J Neurosci 32: 859-865.

51. Kimura A, Imbe H, Donishi T (2009) Axonal projections of auditory cells with short and long response latencies in the medial geniculate nucleus: distinct topographies in the connection with the thalamic reticular nucleus. Eur J Neurosci 30: 783-799.

52. Sambeth A, Maes JH, Quian QR, Coenen AM (2004) Effects of stimulus repetitions on the event-related potential of humans and rats. Int J Psychophysiol 53: $197-205$.

53. Sambeth A, Maes JH, Brankack J (2004) With long intervals, inter-stimulus interval is the critical determinant of the human P300 amplitude. Neurosci Lett 359: 143-146.

54. Näätänen R (1992) Attention and brain function. HillsdaleNew Jersey: Lawrence Erlbaum.

55. Weinberger NM (2010) The medial geniculate, not the amygdala, as the root of auditory fear conditioning. Hear Res.

56. Hara K, Harris RA (2002) The anesthetic mechanism of urethane: the effects on neurotransmitter-gated ion channels. Anesth Analg 94: 313-318.

57. Malmierca MS, Hernandez O, Falconi A, Lopez-Poveda EA, Merchan M, et al. (2003) The commissure of the inferior colliculus shapes frequency response areas in rat: an in vivo study using reversible blockade with microinjection of kynurenic acid. Exp Brain Res 153: 522-529.

58. Malmierca MS, Hernandez O, Rees A (2005) Intercollicular commissural projections modulate neuronal responses in the inferior colliculus. Eur J Neurosci 21: 2701-2710.

59. Merrill EG, Ainswoth A (1972) Glass-coated platinum coated tungsten microelectrodes. Med and Biol Eng 10: 662-672.

60. Malmierca MS, Izquierdo MA, Cristaudo S, Hernandez O, Perez-Gonzalez D, et al. (2008) A discontinuous tonotopic organization in the inferior colliculus of the rat. J Neurosci 28: 4767-4776.

61. Rees A (1990) A close-field sound system for auditory neurophysiology. J of Physiol 430: 2.

62. Rees A, Sarbaz A, Malmierca MS, Le Beau FE (1997) Regularity of firing of neurons in the inferior colliculus. J Neurophysiol 77: 2945-2965.

63. Faure PA, Fremouw T, Casseday JH, Covey E (2003) Temporal masking reveals properties of sound-evoked inhibition in duration-tuned neurons of the inferior colliculus. J Neurosci 23: 3052-3065.

64. Perez-Gonzalez D, Malmierca MS, Moore JM, Hernandez O, Covey E (2006) Duration selective neurons in the inferior colliculus of the rat: topographic distribution and relation of duration sensitivity to other response properties. J Neurophysiol 95: 823-836.

65. Hernandez O, Espinosa N, Perez-Gonzalez D, Malmierca MS (2005) The inferior colliculus of the rat: a quantitative analysis of monaural frequency response areas. Neuroscience 132: 203-217.

66. Paxinos G, Watson C (2005) The Rat Brain in Stereotaxic Coordinates. Burlington: Elsevier-Academic Press. 


\title{
Chapter 49 \\ Is There Stimulus-Specific Adaptation in the Medial Geniculate Body of the Rat?
}

\begin{abstract}
Neurons in the auditory cortex (AC) show a reduced response to a repeated stimulus, but briefly resume firing if a novel stimulus is presented (Nat Neurosci 6:391-398, 2003). This phenomenon is called stimulus-specific adaptation (SSA). This same study concluded that SSA is absent in the medial geniculate body (MGB), and is therefore a unique feature of the AC. More recently, however, SSA has been observed in the inferior colliculus (IC) of a rat (Eur J Neurosci 22:28792885, 2005; J Neuroci 29:5483-5493, 2009). Since the MGB receives its main inputs from the AC and IC, both of which show SSA, we reexamined the issue of whether neurons in the MGB also show SSA. We used a protocol similar to that of Ulanovsky et al. (Nat Neurosci 6:391-398, 2003) to record extracellular single unit responses in the MGB of the urethane-anesthetized rat. Our data demonstrate that SSA is indeed present throughout the MGB, being more prominent in the dorsal and medial subdivisions. Our results taken together with those from the IC indicate that SSA and enhanced responses to novel stimuli are present at every level from the IC on, and we hypothesize that SSA may be shaped, at least in part, through a bottom-up process.
\end{abstract}

\subsection{Introduction}

A novel or unexpected sound may represent potential danger for an animal, compromising its survival. In order to respond adequately, it is necessary to rapidly distinguish what is novel from what is familiar. However, despite the obvious

F.M. Antunes $(\bowtie)$

Auditory Neurophysiology Unit, Institute for Neuroscience of Castilla y Leon,

University of Salamanca, C/Pintor Fernando Gallego,

No 1, 37007 Salamanca, Spain

e-mail: floraa@usal.es 
F.M. Antunes et al.

importance of detecting and responding to novel sounds, the underlying neuronal mechanisms remain unclear. Novelty detection has been extensively studied using the non-invasive technique of recording mismatch negativity (MMN) (Näätänen 1992). However, the identity and location of the neuronal generator of the MMN in the cortex are still unknown, and there is a general lack of knowledge about novelty processing at subcortical levels (Deouell 2007).

In a dynamic environment where changes in the auditory scene occur continuously, it would be adaptive for animals to be able to continuously modulate the state of their nervous system (Mountcastle 1995; Ulanovsky et al. 2004; Wark et al. 2007). These changes would likely be reflected in changes in neuronal firing patterns, particularly any population of neurons involved in the detection of novel sounds occurring in a background of familiar and uninteresting sounds.

Neural adaptation is a ubiquitous process in biological systems (Ranganath and Rainer 2003; Wallach et al. 2008), and it is well known to occur in various forms in the olfactory (Best et al. 2005), visual (Kohn 2007) and auditory systems (Dean et al. 2008; Eytan et al. 2003; Fritz et al. 2007; Yu et al. 2008). However, Ulanovsky and colleagues $(2003,2004)$ were the first to show that auditory cortex (AC) neurons show a reduced response to a repeated stimulus (standard), and briefly resume firing if a novel stimulus (oddball) is presented. This phenomenon is referred to as stimulus-specific adaptation (SSA) and has been proposed as a single neuron correlate of the MMN in humans (Nelken and Ulanovsky 2007; Ulanovsky et al. 2003, 2004).

The approach used by Ulanovsky et al. (2003) employed a probabilistic stimulus approach, and demonstrated that AC neurons in a cat experience a very rapid form of adaptation that is highly sensitive to stimulus statistics and occurs with a long latency. When they tested neurons in the medial geniculate body (MGB) of the cat using the same stimulus approach, they did not observe any sign of SSA. On this basis, they concluded that SSA is generated by cortical processing. Subsequently, however, SSA has been demonstrated in the inferior colliculus (IC) of both the rat (Malmierca et al. 2009; Perez-Gonzalez et al. 2005) and the barn owl (Reches and Gutfreund 2008).

The IC is the target for most of the auditory pathways that originate in the lower brainstem, and it is also the principal source of ascending input to the MGB (for review see (Malmierca 2003)). The MGB in turn, represents the main auditory center of the thalamus, and is therefore the last center for auditory processing before inputs reach the AC (Malmierca 2003; Winer et al. 2005; Lee and Winer 2008). All MGB subdivisions receive massive descending projections from the AC that are about ten times more abundant than the ascending projections from the IC. As in the case of other corticothalamic projections, the descending pathways have been implicated in gain control, signal filtering, and other dynamic functions (Lee and Winer 2005; Winer et al. 2001; Malmierca and Ryugo 2009).

Since both the IC (Malmierca et al. 2009; Perez-Gonzalez et al. 2005) and the AC (Ulanovsky et al. 2003, 2004) contain neurons that exhibit SSA, one would expect MGB neurons to inherit this property from the IC, the AC, or both. The purpose of the current study was to reexamine this issue, using a probabilistic 
stimulus paradigm similar to that of Ulanovsky et al. (2003), recording from a larger population of neurons throughout all subdivisions of the MGB. Our results demonstrate that SSA is indeed present throughout the MGB in the rat, being more prominent in the dorsal and medial subdivisions. We also discuss how SSA in the MGB differs from that of the AC and IC in an attempt to understand the mechanisms that govern SSA and whether it is simply a property inherited through excitatory descending projections from the AC or whether a bottom-up process could be involved.

\subsection{Materials and Methods}

\subsubsection{Surgical Procedures, Acoustic Stimuli, and Electrophysiological Recording}

Experiments were performed on adult rats weighting between 160 and $280 \mathrm{~g}$. All experiments were carried out at the University of Salamanca with the approval, and using methods conforming to the standards, of the University of Salamanca Animal Care Committee. Full details of surgical preparation were as described elsewhere (Malmierca et al. 2005, 2008, 2009; Perez-Gonzalez et al. 2005). Here, it suffices to mention that surgical anesthesia was induced and maintained with urethane $(1.5 \mathrm{~g} / \mathrm{kg}$, i.p.), with supplementary doses $(0.5 \mathrm{~g} / \mathrm{kg}$, i.p.) given as needed. The trachea was cannulated, and atropine sulfate $(0.05 \mathrm{mg} / \mathrm{kg}$, s.c.) was administered to reduce bronchial secretions. Body temperature was maintained at $38 \pm 1^{\circ} \mathrm{C}$. The animal was placed in a stereotaxic frame in which the ear bars were replaced by hollow specula that accommodated a sound delivery system.

A craniotomy was performed to expose the cerebral cortex overlying the MGB. A tungsten electrode (1-2 M $\Omega$; Merryll and Ainswoth 1972) was lowered through the cortex and used to record extracellular single unit responses in the MGB. Neuron location in the MGB was based on stereotaxic coordinates, response properties, and histological verification using electrolytic lesions $(5-10 \mu \mathrm{A}$ for 5-10 s) to mark recording sites and identify subdivisions (Winer et al. 1999).

Stimuli were delivered through a sealed acoustic system (Malmierca et al. 2008; Perez-Gonzalez et al. 2005; Rees 1990) using two electrostatic loudspeakers (TDT-EC1) driven by two TDT-ED1 modules. Pure tone bursts were delivered to one or both ears under computer control using TDT System 2 (Tucker-Davis Technologies) hardware and custom software. Typically, tones were $75 \mathrm{~ms}$ duration with a $5 \mathrm{~ms}$ rise/fall time. Selected parameters were varied one at a time during testing. Action potentials were recorded with a BIOAMP amplifier (TDT), before passing through a spike discriminator (TDT SD1). Spike times were displayed as dot rasters ordered by the acoustic parameter varied during testing. Search stimuli were pure tones or noise bursts. The frequency response area (FRA), i.e., the combination of frequencies and intensities capable of evoking a response was obtained automatically using a randomized stimulus presentation paradigm. 
F.M. Antunes et al.

\subsubsection{Stimulus Presentation Paradigms}

For all neurons, stimuli were presented in an oddball paradigm similar to that used to record MMN responses in human studies (Näätänen 1992) and more recently in the cat auditory cortex (Ulanovsky et al. 2003, 2004) and the rat IC (Malmierca et al. 2009). Briefly, we presented two stimuli consisting of pure tones at two different frequencies $\left(f_{1}\right.$ and $\left.f_{2}\right)$ that elicited a similar firing rate at a level of 10-40 dB above threshold. Both frequencies were within the excitatory FRA previously determined for the neuron. We presented a train of 400 stimuli containing both frequencies in a probabilistic manner at a specific repetition rate. One frequency $\left(f_{1}\right)$ was presented as the standard (i.e., 90\% probability within the sequence); interspersed randomly among the standards were the oddball stimuli (i.e., $10 \%$ probability) at the second frequency $\left(f_{2}\right)$. After obtaining one data set, the relative probabilities of the two stimuli were reversed, with $f_{2}$ as the standard and $f_{1}$ as the oddball. The responses to the standard stimulus and oddball stimulus were normalized to account for the different number of presentations in each condition, due to the different probabilities.

The same paradigm was repeated varying the inter-stimulus interval (ISI $=250$ and $500 \mathrm{~ms}$ ), or the frequency contrast between the standard and oddball. The frequency contrasts were chosen to be as close as possible to values that have been used in other studies, i.e., $\Delta f=0.37,0.10$ and 0.04 ; where $\Delta f=\left(f_{2}-f_{1}\right) /\left(f_{2} \times f_{1}\right)^{1 / 2}$ is the normalized frequency difference (Ulanovsky et al. 2003, 2004). To quantify the amount of SSA that occurred, we calculated two different forms of the stimulusspecific adaptation index (SSA index) using the method described by Ulanovsky et al. $(2003,2004)$. One was the frequency-specific index $\operatorname{SI}\left(f_{i}\right)$ where $i=1$ or 2 , defined for each frequency $f_{i}$ as $\operatorname{SI}\left(f_{i}\right)=\left[d\left(f_{i}\right)-s\left(f_{i}\right)\right] /\left[d\left(f_{i}\right)+s\left(f_{i}\right)\right]$, where $d\left(f_{i}\right)$ and $s\left(f_{i}\right)$ are responses (i.e. normalized spike counts) to frequency $f_{i}$ when it was oddball or standard, respectively. The other SSA index was the neuron-specific index defined as NSSI $=\left[d\left(f_{1}\right)+d\left(f_{2}\right)-s\left(f_{1}\right)-s\left(f_{2}\right)\right] /\left[d\left(f_{1}\right)+d\left(f_{2}\right)+s\left(f_{1}\right)+s\left(f_{2}\right)\right]$, where $d(f)$ and $s(f)$ are responses to each frequency $f_{1}$ or $f_{2}$ when they were the oddball or standard stimuli, respectively. These indices reflect the extent to which a neuron's response to the standard was suppressed and/or response to the oddball was enhanced. The possible range of NSSI values is from -1 to +1 , being positive if the response to the oddball stimulus was greater and negative if the response to the standard stimulus was greater. To determine the conditions that elicited SSA and novelty responses in a given neuron, the indices were analyzed as a function of $\Delta f$ and ISI.

\subsection{Results}

We recorded from 63 single neurons throughout the three main subdivisions of the MGB, while presenting the oddball stimulus paradigm. Our data indicate that about half of the MGB neurons responded more strongly to the oddball stimulus than to the standard, regardless of whether it was $f_{1}$ or $f_{2}$. Histological localization of 


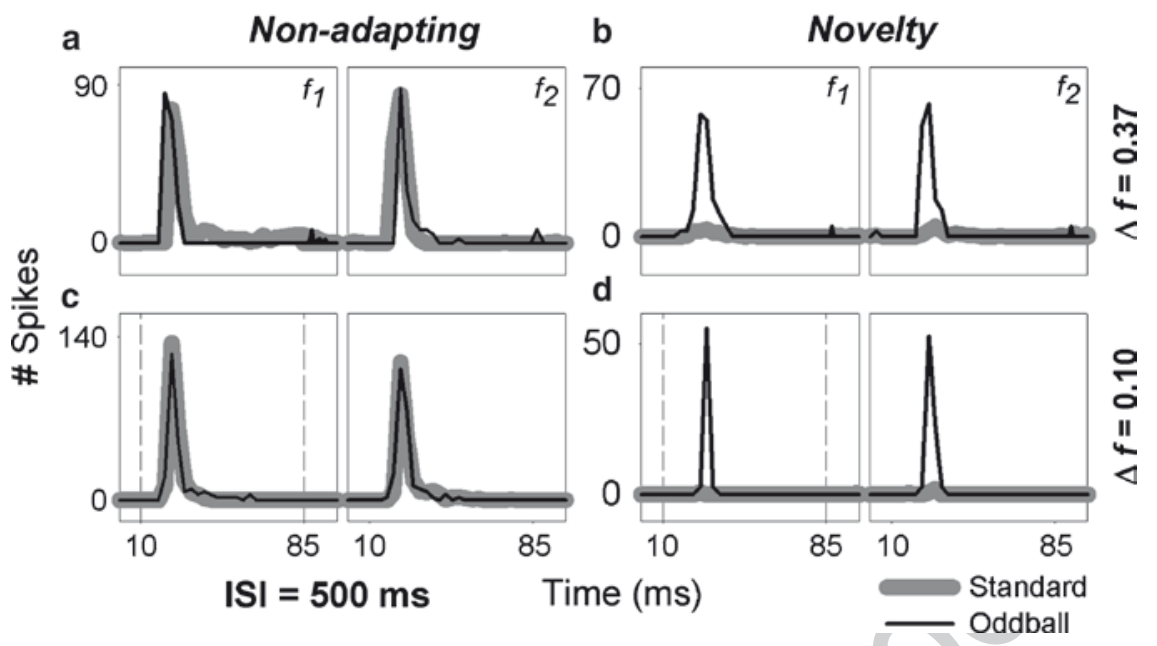

Fig. 49.1 Examples of the responses of four neurons to the oddball stimulus paradigm at $500 \mathrm{~ms}$ ISI (425 ms inter-tone pause), for $\Delta f=0.37$ and $\Delta f=0.10$. Dotted vertical lines indicate the duration of the stimulus $(75 \mathrm{~ms})$. Black and grey lines represent the neuronal activity, i.e., number of spikes normalized to 100 trials as a function of time, in response to the oddball and standard stimulus, respectively. (a, c) Nonadapting neurons. Activity of these neurons is similar for the oddball and standard frequency. NSSI $=-0.09$ and NSSI $=0.02$ for $(\mathbf{a})$ and $(\mathbf{c})$, respectively. (b, d) Novelty neurons. Activity of these neurons is stronger to the oddball than to the standard frequency. NSSI $=0.97$ and NSSI $=0.96$ for $(\mathbf{b})$ and $(\mathbf{d})$, respectively

recording sites within the three main subdivisions of the MGB showed that SSA is indeed present throughout the MGB in the rat, although it is more prominent in the dorsal and medial subdivisions.

Figure 49.1 shows examples of the responses of four MGB neurons to the oddball stimulus paradigm, at two different frequency contrasts $(\Delta f=0.37$ and 0.10$)$, and a $425 \mathrm{~ms}$ inter-tone duration. Two of these neurons did not show any degree of SSA (nonadapting, Fig. 49.1a, c) while two others exhibited robust SSA (novelty, Fig. 49.1b, d). Black and grey lines represent the number of spikes normalized to 100 trials as a function of time, in response to the oddball and standard stimulus, respectively. For each neuron, we show the neuronal responses to $f_{1}$ and $f_{2}$. By definition, the responses of the nonadapting neurons to each frequency were similar regardless of whether the frequency was presented as the standard or the oddball, whereas for the novelty neurons, the responses were significantly stronger to either frequency when it was the oddball than when it was the standard.

The examples shown in Fig. 49.1 represent neurons with extreme SSA values. However, across the MGB population as a whole, the distribution of NSSI values forms a continuum covering the entire range between the extremes of 0 and +1 .

Figure 49.2 illustrates population data across all neurons, and illustrates the continuous nature of NSSI distribution. Because each neuron was tested under multiple conditions, we calculated an average NSSI value across conditions. Since not all neurons were tested with all conditions, we considered only those neurons 
F.M. Antunes et al.

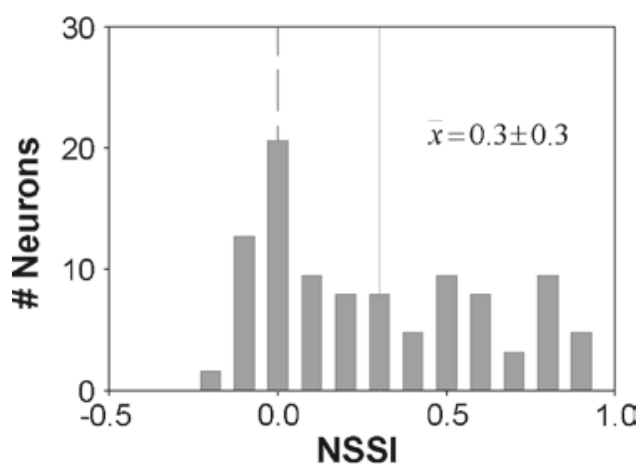

Fig. 49.2 Population number of neurons as a function of the NSSI, averaged for all NSSI values obtained across conditions for each neuron. The majority of neurons $(86 \%)$ had positive NSSI values ranging between 0 and 1 . Mean NSSI $=0.3 \pm 0.3$, significantly larger than zero ( $t$-test for mean $>0: p<0.0001)$

with two or more conditions for this analysis ( $n=59$ neurons). These results show that $86 \%$ of the neurons had positive average NSSI values, and that there was a continuous distribution all the way to 0.99 . The mean NSSI of the whole population is positive (mean $=0.34 \pm 0.33$ ) and significantly larger than zero $(t$-test for mean $>0$ : $p<0.0001)$. Only a few neurons had negative values $(n=9 ; 14 \%$, ranging between $\mathrm{NSSI}=-0.17$ and -0.006 ), meaning that their overall response to the standard was stronger than that of the oddball. However, all but one (NSSI $=-0.17$ ) of these negative values were not significantly different from zero $(t$-test: $p<0.05)$. For descriptive purposes, we have classified MGB neurons into three different types: nonadapting neurons (if all NSSI $<0.25$ under all conditions), novelty neurons (if all NSSI $>0.5$ under all conditions), and partially adapting neurons (if NSSI $>0.5$ in some but not all conditions). Nonadapting neurons made up nearly half of the population $(49 \% ; n=29$, including the negative values; mean NSSI $=0.05 \pm 0.1$ ) The next largest class was novelty neurons $(36 \% ; n=21$; mean NSSI $=0.74 \pm 0.14)$ followed by partially adapting neurons $(15 \% ; n=9$; mean NSSI $=0.36 \pm 0.08)$.

Figure 49.3 shows scatter plots of the frequency-specific SSA index, $\operatorname{SI}\left(f_{1}\right)$ vs. $\operatorname{SI}\left(f_{2}\right)$ for the neurons, tested at three different frequency contrast values $(\Delta f=0.37$, 0.10 and 0.04 ) and two different inter-stimulus intervals (ISI $=500$ and $250 \mathrm{~ms}$ ). The majority of points lie above the diagonal, in the upper right quadrant of the scatter plot, for almost all conditions, confirming that SSA is present at the population level. However, at the minimum frequency contrast tested $(\Delta f=0.04)$ and the highest ISI $(500 \mathrm{~ms})$, points are distributed around zero both above and below the diagonal. It is noteworthy that, at $\Delta f=0.37$ and 0.10 , there is a cluster of points in the right upper corner of the scatter plot at both ISI. These neurons have an SI $>0.6$ for both $f_{1}$ and $f_{2}$, and represent the highest degree of novelty selectivity. Even at $\Delta f=0.04$, three neurons maintained a high degree of novelty selectivity for both ISI, suggesting that a small percentage of neurons in the MGB exhibit SSA at this very small frequency contrast, corresponding to 0.57 octaves. 


\section{Author's Proof}

49 Is There Stimulus-Specific Adaptation in the Medial Geniculate Body of the Rat?

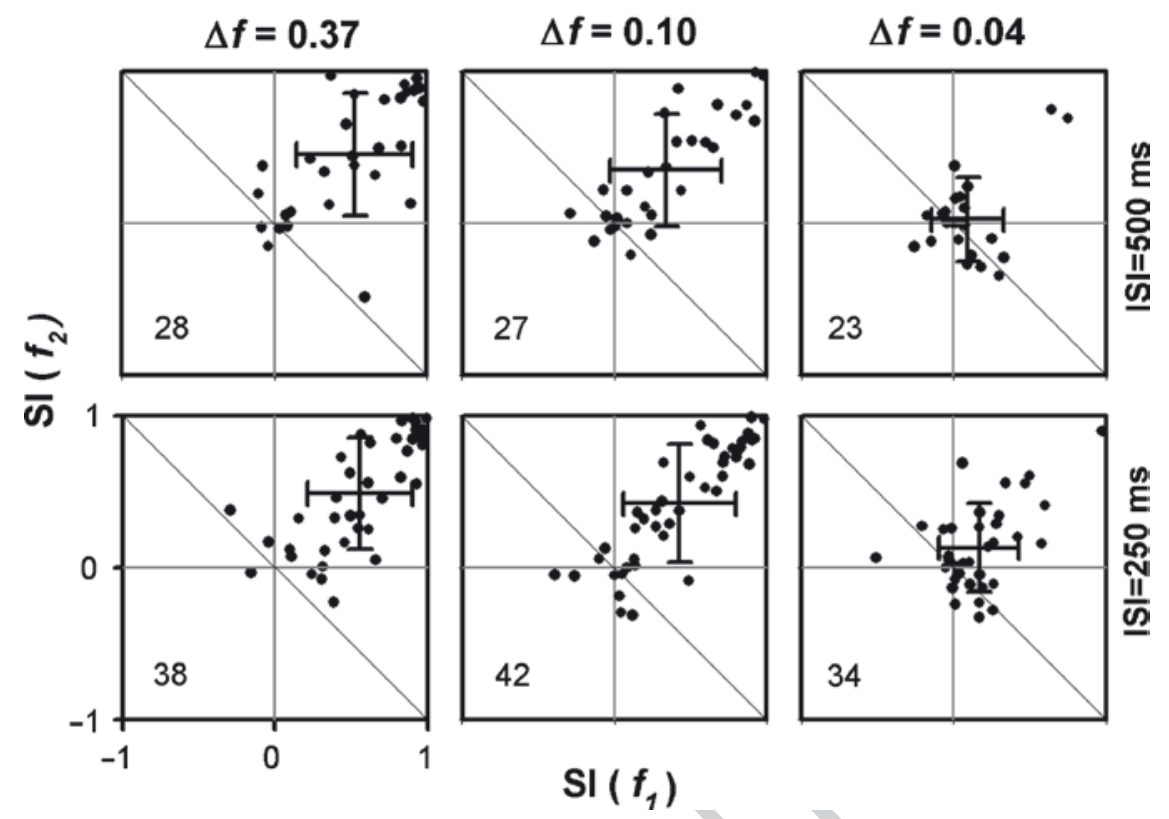

Fig. 49.3 Frequency-specific indices $\operatorname{SI}\left(f_{1}\right)$ vs. $\operatorname{SI}\left(f_{2}\right)$ values obtained separately for the different frequency contrast values $(\Delta f=0.37,0.10$ and 0.04$)$ and ISI ( 250 and $500 \mathrm{~ms}$ ). Neurons that were tested for more than one condition are represented in more than one panel. Each point represents data from one neuron. Number in the lower left quadrant is the number of neurons for each condition. Crosses indicate the mean and standard deviation for each axis. Neurons above the diagonal indicate the presence of SSA. There are neurons with high $\operatorname{SI}\left(f_{i}\right)$ values in all conditions tested, being more pronounced for $\Delta f=0.37$ and 0.10

Therefore, SSA is present at the population level in the MGB, with a high percentage of neurons showing strong SSA. The degree of SSA varies with the stimulus repetition rate and the frequency difference between $f_{1}$ and $f_{2}$.

\subsection{Discussion}

The present study demonstrates that a large percentage of neurons in the MGB of the anesthetized rat show some degree of SSA. Although a large number of neurons had high NSSI values for the largest $\Delta f$ tested, it is also clear that a few neurons also exhibit high SSA for $\Delta f$ as small as 0.04 , i.e., 0.57 octaves. Our results are in agreement with previous findings from the AC and IC in that the amount of SSA is positively correlated with both the ISI and the magnitude of the frequency contrast (Ulanovsky et al. 2003; Malmierca et al. 2009).

Before discussing our results in a functional context and comparing them 
F.M. Antunes et al.

Special care was taken to choose two frequencies $\left(f_{1}\right.$ and $\left.f_{2}\right)$ that were within the excitatory portion of the FRA and elicited similar spike counts when presented randomly during measurement of the FRA. By doing so, we could be certain that the recorded SSA response was related to the probability of occurrence and not to frequency interactions. Additionally, we only used files with a similar SI for both frequencies, excluding those in which $\left[\operatorname{SI}\left(f_{1}\right)-\operatorname{SI}\left(f_{2}\right)>0.5\right]$.

In the present study, we recorded neurons with very high values of $\operatorname{SI}\left(f_{i}\right)$ ([SI $\left.\left(f_{1}\right) \approx \operatorname{SI}\left(f_{2}\right) \approx 0.9\right]$, see examples in Fig. $49.1 \mathrm{~b}$, d), which genuinely reflects stronger neuronal adaptation to the standard than to the oddball stimuli. MGB neurons seem to be similar to those in the AC of the cat (Ulanovsky et al. 2003) and the IC of the rat (Malmierca et al. 2009) with regard to the parameter ranges over that which we tested SSA in the MGB neurons. Since the MGB receives inputs from both the IC (Malmierca 2003; Oliver et al. 1999) and the AC (Lee and Winer 2005; Malmierca and Ryugo 2009; Winer et al. 2001) it is not surprising that MGB neurons show SSA. A previous study using a cat and based on a rather small sample ( $n=27$, Ulanovsky et al. 2003) failed to demonstrate SSA in the MGB using $\Delta f=0.10$ and an ISI of $736 \mathrm{~ms}$ (i.e., an inter-tone pause of $506 \mathrm{~ms}$, for a tone duration of $230 \mathrm{~ms}$ ). But using similar parameters $(\Delta f=0.10$ and inter-tone pause of $425 \mathrm{~ms}$ ) we found neurons with extreme NSSI values in the MGB of the rat. These differences may be due to interspecies differences in SSA processing and/or other factors such as anesthesia, recording procedures, or merely sample size.

An important finding is that MGB neurons do not seem to be organized into discrete groups according to their SSA sensitivity. Rather, MGB neurons show a gradient in the amount of SSA throughout all the MGB subdivisions. Nevertheless, there are some regional differences. Neurons in the ventral division show some degree of SSA (NSSI values can be as large as 0.48), but the highest NSSI values (up to 0.99) were found in neurons from the medial and dorsal divisions. Similarly, SSA observed in the IC was more robust in the dorsal, lateral and rostral cortices (Perez-Gonzalez et al. 2005; Malmierca et al. 2009). These findings taken together suggest that SSA may be more important in the paralemniscal auditory pathway, which is known to be implicated in polysensory interactions and the processing of other complex features of sound such as fear conditioning or auditory learning (Malmierca et al. 2002; Malmierca 2003).

Another important similarity between SSA in MGB and IC neurons is related to neuronal response type and the latency for SSA to reduce spike counts within a response. As in the case of the IC (Perez-Gonzalez et al. 2005; Malmierca et al. 2009), we found that high SSA neurons in the MGB were mainly onset responders, with short latencies for both the standard and the oddball stimuli. This argues against the idea of an additional processing time required for a cortical modulation effect to occur. In this sense, SSA in the thalamus and in midbrain seems to differ from SSA in the AC, where SSA is expressed mostly in the late portion of sustained responses, suggesting the contribution of intracortical processing (Ulanovsky et al. 2003). It remains unclear to what extent SSA observed in the MGB is due to thalamic processing or to what extent it reflects processing that has already occurred in the IC or AC. 
49 Is There Stimulus-Specific Adaptation in the Medial Geniculate Body of the Rat?

In conclusion, our data demonstrate for the first time that SSA is present 258 throughout the MGB of the rat. The comparison of our MGB results with those 259 from the IC and AC studies reveal many similarities between the MGB and the IC 260 and AC in terms of SSA. This leads us to hypothesize that SSA, at least in part, is 261 created at the midbrain level and transmitted in a bottom-up process through the 262 ascending pathway. What is unclear so far is to what extent the AC modulates SSA 263 subcortically through the descending pathway. This issue needs to be explored in 264 future experiments.

Acknowledgments Research was supported by the Spanish MEC (BFU2006-00572) and JCYL (GR221) to MSM and the NSF (IOS-0719295) grant to EC. FMA was supported by a Spanish MEC fellowship (BES-2007-15642).

\section{References}

Best AR, Thompson JV, Fletcher ML, Wilson DA (2005) Cortical metabotropic glutamate 270 receptors contribute to habituation of a simple odor-evoked behavior. J Neurosci 25: 271 2513-2517

Dean I, Robinson BL, Harper NS, McAlpine D (2008) Rapid neural adaptation to sound level statistics. J Neurosci 28:6430-6438

266

Deouell LY (2007) The frontal generator of mismatch negativity revisited. J Psychophysiol 21:188-203

Eytan D, Brenner N, Marom S (2003) Selective adaptation in networks of cortical neurons. J Neurosci 23:9349-9356

Fritz JB, Elhilali M, David SV, Shamma SA (2007) Auditory attention - focusing the searchlight on sound. Curr Opin Neurobiol 17:437-455

Kohn A (2007) Visual adaptation: physiology, mechanisms, and functional benefits. J Neurophysiol 97:3155-3164

Lee CC, Winer JA (2005) Principles governing auditory cortex connections. Cereb Cortex 15:1804-1814

Lee CC, Winer JA (2008) Connections of cat auditory cortex: I. Thalamocortical system. J Comp Neurol 507:1879-1900

Malmierca MS (2003) The structure and physiology of the rat auditory system: an overview. Int Rev Neurobiol 56:147-211

Malmierca MS, Ryugo DK (2009) Cortical descending projections to auditory midbrain and brainstem. In: Winer JA, Schreiner CE (eds) The auditory cortex. Springer, New York

Malmierca MS, Merchan MA, Henkel CK, Oliver DL (2002) Direct projections from cochlear nuclear complex to auditory thalamus in the rat. J Neurosci 22:10891-10897

Malmierca MS, Hernandez O, Rees A (2005) Intercollicular commissural projections modulate neuronal responses in the inferior colliculus. Eur J Neurosci 21:2701-2710

Malmierca MS, Izquierdo MA, Cristaudo S, Hernandez O, Perez-Gonzalez D, Covey E, Oliver DL (2008) A discontinuous tonotopic organization in the inferior colliculus of the rat. J Neurosci 28:4767-4776

Malmierca MS, Cristaudo S, Perez-Gonzalez D, Covey E (2009) Stimulus-specific adaptation in the inferior colliculus of the anesthetized rat. J Neurosci 29(17):5483-5493

Merryll EG, Ainswoth A (1972) Glass-coated platinum coated tungsten microelectrodes. Med Biol Eng 10:662-672

Mountcastle V (1995) The evolution of ideas concerning the function of the neocortex. Cereb Cortex 5:289-295 
F.M. Antunes et al.

Näätänen R (1992) Attention and brain function. Lawrence Erlbaum, Hillsdale, New Jersey

Nelken I, Ulanovsky N (2007) Mismatch negativity and stimulus-specific adaptation in animal models. J Psychophysiol 21:214-223

Oliver DL, Ostapoff EM, Beckius GE (1999) Direct innervation of identified tectothalamic neurons in the inferior colliculus by axons from the cochlear nucleus. Neuroscience 93:643-658

Perez-Gonzalez D, Malmierca MS, Covey E (2005) Novelty detector neurons in the mammalian auditory midbrain. Eur J Neurosci 22:2879-2885

Reches A, Gutfreund Y (2008) Stimulus-specific adaptations in the gaze control system of the barn owl. J Neurosci 28:1523-1533

Rees A (1990) A close-field sound system for auditory neurophysiology. J Physiol 430:2

Ulanovsky N, Las L, Nelken I (2003) Processing of low-probability sounds by cortical neurons. Nat Neurosci 6:391-398

Ulanovsky N, Las L, Farkas D, Nelken I (2004) Multiple time scales of adaptation in auditory cortex neurons. J Neurosci 24:10440-10453

Wark B, Lundstrom BN, Fairhall A (2007) Sensory adaptation. Curr Opin Neurobiol 17:423-429

Winer JA, Kelly JB, Larue DT (1999) Neural architecture of the rat medial geniculate body. Hear Res 130:19-41

Winer JA, Diehl JJ, Larue DT (2001) Projections of auditory cortex to the medial geniculate body of the cat. J Comp Neurol 430:27-55

Winer JA, Miller LM, Lee CC, Schreiner CE (2005) Auditory thalamocortical transformation: structure and function. Trends Neurosci 28:255-263

Yu X, Xu X, Chen X, He S, He J (2008) Slow recovery from excitation of thalamic reticular nucleus neurons. J Neurophysiol 101(2):980-987 
SENIOR EDITOR: EARL MILLER

REVIEWEING EdITOR: MARTY USREY

TITLE:

CORTICOFUGAL MODULATION OF STIMULUS-SPECIFIC ADAPTATION IN THE MEDIAL GENICULATE BODY

AUTHORS:

Flora M. Antunes ${ }^{1}$ and Manuel S. Malmierca ${ }^{1,2}$

Affiliations:

1. Auditory Neurophysiology Unit. Laboratory for the Neurobiology of Hearing. Institute of Neuroscience of Castilla y León. University of Salamanca. C/ Pintor Fernando Gallego, 1, 37007 Salamanca. Spain

2. Department of Cell Biology and Pathology. Faculty of Medicine. University of Salamanca. Campus Miguel de Unamuno. 37007 Salamanca. Spain.

\section{CORRESPONDING AUTHOR:}

Manuel S. Malmierca, M.D., Ph.D.

Auditory Neurophysiology Unit. Institute of Neuroscience of Castilla y León. University of Salamanca. C/ Pintor Fernando Gallego, 1, 37007 Salamanca. Spain Email. msm@usal.es

Total Number of Words in abstract: 146

Total Number of Words in introduction: 517

Total Number of Words in Discusion: 1256

Total Number of Figures: 6

RUNNING TITLE:

TOP-DOWN MODULATION OF SSA IN THE AUDITORY THALAMUS

\section{KEY WORDS:}

Stimulus-specific adaptation, thalamus, auditory, gain control, cortical modulation.

\section{Acknowledgements:}

We are most grateful to Alan Palmer for his assistance in setting up the cooling technique. We also thank Drs. Israel Nelken, Daniel Llano, Adrian Rees, Alan Palmer 
and Xiaoqin Wang for their critical and valuable comments on a previous version of the manuscript.

Financial support was provided by the Spanish MEC (BFU2009-07286), EU (EUI200904083) and JCYL-UE (GR221) to MSM. FMA held a fellowship from the Spanish MEC (BES-2007-15642).

FMA performed experiments, collected and analyzed data and wrote the manuscript; MSM designed the experiments, wrote the manuscript and supervised the project. All authors discussed the results and implications and commented on the manuscript at all stages. 


\section{ABSTRACT}

An animal's survival may depend on detecting new events or objects in its environment and it is likely that the brain has evolved specific mechanisms to detect such changes. In sensory systems neurons often exhibit stimulus-specific adaptation (SSA) whereby they adapt to frequently occurring stimuli, but resume firing when 'surprised' by rare or new ones. In the auditory system, SSA occurs in the midbrain, thalamus and auditory cortex (AC). It has been proposed that the SSA observed subcortically originates in the AC as a high order property that is transmitted to the subcortical nuclei via corticofugal pathways. Here we report that SSA in the auditory thalamus remains intact when the AC is deactivated by cooling, thus demonstrating that the AC is not necessary for the generation of SSA in the thalamus. The AC does, however, modulate the responses of thalamic neurons in a gain control fashion. 


\section{INTRODUCTION}

In nature, a critical task of the brain is to detect and attend to rare stimuli (Ranganath and Rainer, 2003). At the single-neuron level, the detection of rare stimuli is reflected by stimulus-specific adaptation (SSA), in which neurons respond strongly to rare stimulus while adapting to frequently occurring ones (Antunes et al., 2010;Gutfreund and Knudsen, 2006;Malmierca et al., 2009;Reches and Gutfreund, 2008;Reches et al., 2010;Ulanovsky et al., 2003;von der Behrens et al., 2009). SSA depends on the history of the stimulation rather than on the activity of the neuron (Ulanovsky et al., 2003;Ulanovsky et al., 2004). Neurons showing SSA integrate sensory information to create a predictive model of the stimulation, detecting deviant features in the environment. In the auditory brain, SSA has been linked to auditory memory, recognition of acoustic objects and scene analysis (Nelken, 2004;Winkler et al., 2009). Throughout the auditory pathway, SSA to the frequency of the acoustic stimulus occurs in the midbrain, thalamus and cortex (Antunes et al., 2010;Gutfreund and Knudsen, 2006;Malmierca et al., 2009;Reches and Gutfreund, 2008;Reches et al., 2010;Ulanovsky et al., 2003;von der Behrens et al., 2009). SSA is strong in the nonlemniscal subcortical regions (Antunes et al., 2010;Malmierca et al., 2009), but the primary AC is the first lemniscal station where it is widespread and strong (Ulanovsky et al., 2003). Thus, SSA has been suggested to emerge in the AC as a high order feature of sensory processing that can be transmitted to subcortical nuclei in a top-down fashion (Nelken and Ulanovsky, 2007). However, this hypothesis remains unexplored.

Herein, we test the hypothesis that SSA in thalamic neurons is inherited via corticofugal projections. A remarkable feature of the thalamus is the massive set of corticofugal projections it receives. In the auditory thalamus (the medial geniculate body, MGB), these projections outnumber the ascending projections by a factor of 10 
(Kimura et al., 2005;Lee and Winer, 2005;Ojima and Rouiller, 2011;Winer et al., 2001) and strongly modulate the responses of MGB neurons(He, 2003a;He, 2003b;Palmer et al., 2007;Ryugo and Weinberger, 1976;Villa and Abeles, 1990;Villa et al., 1991;Villa et al., 1999). This corticothalamic projection mainly originates in layer VI pyramidal neurons, whose terminals are small and modulatory in nature. A numerically smaller corticothalamic projection arises from layer V neurons and produces large terminals that are able to drive post-synaptic responses(Bajo et al., 1995;Bartlett et al., 2000;Ojima, 1994;Rouiller and Welker, 1991;Rouiller and Welker, 2000;Sherman and Guillery, 1998).

Here, we recorded the responses of single neurons throughout the MGB, before, during and after reversibly deactivating the AC by cooling (Lomber, 1999;Lomber et al., 1999;Ryugo and Weinberger, 1976;Villa et al., 1991) while stimulating the animal with tones of two frequencies in an oddball paradigm to elicit SSA (Antunes et al., 2010;Ulanovsky et al., 2003). Our results demonstrate that the responses of MGB neurons were significantly modified but the SSA levels and its temporal dynamics were mostly unaffected during AC deactivation. These findings demonstrate that SSA in the MGB is not inherited from the AC, but rather, the AC modulates the responses of MGB neurons in a gain control manner. Preliminary reports have been presented elsewhere (Antunes and Malmierca, 2011). 


\section{MATHERIALS AND METHODS}

\section{Surgical procedures and electrophysiological recordings}

Experiments were performed on 17 adult rats with body weights between 150-250 g. All experiments were carried out at the University of Salamanca with the approval of, and using methods conforming to the standards of the University of Salamanca Animal Care Committee. Details of surgical and recording procedures were as described in detail elsewhere (Antunes et al., 2010). Surgical anaesthesia was induced and maintained with urethane (1.5 g/kg, i.p.; 0.5 g/kg, i.p. supplementary if needed). A craniotomy was performed to expose the cerebral cortex overlying the MGB and the ipsilateral AC. A tungsten electrode (1-2 M $\Omega$; (Merryll and Ainswoth, 1972)) was used to record extracellular single unit responses. Stimuli were delivered through a sealed acoustic system (Malmierca et al., 2005;Malmierca et al., 2008;Rees, 1990) using two electrostatic loudspeakers (TDT- EC1) driven by two TDT-ED1 modules. All stimuli were generated and delivered to the contralateral ear using TDT System 2 (TuckerDavis Technologies) hardware and custom software (Malmierca et al., 2009). The output of the system at each ear was calibrated in situ using a 1/4,' condenser microphone (Brüel and Kjær 4136, Nærum, Denmark) and a DI-2200 spectrum analyser (Diagnostic Instruments Ltd., Livingston, Scotland, UK). The maximum output of the TDT system was flat from $0.3-5 \mathrm{kHz}(\sim 100 \pm 7 \mathrm{~dB}$ SPL) and from $5-40 \mathrm{kHz}(90 \pm 5 \mathrm{~dB}$ SPL). The highest frequency produced by this system was limited to $40 \mathrm{kHz}$. The second and third harmonic components in the signal were $40 \mathrm{~dB}$ or more below the level of the fundamental at the highest output level(Malmierca et al., 2008;Malmierca et al., 2009). Action potentials were recorded with a BIOAMP amplifier (TDT), the 10X output of which was further amplified and bandpass-filtered (TDT PC1; $\mathrm{f}_{\mathrm{c}}, 500 \mathrm{~Hz}$ and 
$3 \mathrm{kHz}$ ) before passing through a spike discriminator (TDT SD1). Spike times were logged on a computer by feeding the output of the spike discriminator into an event timer (TDT ET1) synchronized to a timing generator (TDT TG6). The monaural frequency response area (FRA, e.g., Fig. 1), was obtained automatically using a randomized stimulus presentation paradigm (frequency steps and intensity levels) and plotted using MATLAB. Stimuli to measure FRAs in single units were 75-ms duration pure tones (5-ms rise/fall time). Frequency and intensity of the stimulus were varied randomly (0-100 dB attenuation in 5 or $10 \mathrm{~dB}$ levels and in 25 frequency steps from 0.1-40, to cover approximately 2-3 octaves above and below the BF (Malmierca et al., 2008).

\section{Stimulus presentation paradigm}

Stimuli were presented in an oddball paradigm similar to that used previously (Antunes et al., 2010;Malmierca et al., 2009;Ulanovsky et al., 2003), consisting of two different pure tone stimuli ( $f_{1}$ and $f_{2}$ ), at 10-40 dB level above threshold. Both frequencies were within the excitatory FRA previously determined for the neuron and had a frequency ratio of 0.141 octaves, i.e., a normalized frequency difference $\Delta f=0.10$; where $\Delta f$ $=\left(\mathrm{f}_{2}-\mathrm{f}_{1}\right) /\left(\mathrm{f}_{2} * \mathrm{f}_{1}\right)^{1 / 2}$ (Antunes et al., 2010;Malmierca et al., 2009;Ulanovsky et al., 2003). A train of 400 stimuli containing both frequencies in a pseudo-random order, at a $4 \mathrm{~Hz}$ repetition rate was presented, varying the probability of each frequency: $f_{1}$ was presented with $90 \%$ probability (standard) and $\mathrm{f}_{2}$ was presented with $10 \%$ probability (deviant) within the sequence. A second train was then presented, in which the probabilities of the two stimuli were reversed ( $f_{2}$ as standard; $f_{1}$ as deviant). The sound frequencies of each pair were chosen to elicit similar spike counts when presented individually, to ensure that all differences in response were due to the statistics of the stimulus ensemble (compare Fig. 1d and g; p and s; similar response in the two blocks 
to the standard and the deviant of each neuron, independently of which frequency of the pair was presented as standard or deviant). The parameters chosen were demonstrated to effectively elicit SSA on the MGB neurons (Antunes et al., 2010). SSA was quantified as described previously (Antunes et al., 2010;Malmierca et al., 2009;Ulanovsky et al., 2003). The frequency-specific SSA index, $\operatorname{SI}\left(\mathrm{f}_{\mathrm{i}}\right)(\mathrm{i}=1$ or 2$)$, was calculated as $\operatorname{SI}\left(f_{i}\right)=\left[d\left(f_{i}\right)-s\left(f_{i}\right)\right] /\left[d\left(f_{i}\right)+s\left(f_{i}\right)\right]$ where $d\left(f_{i}\right)$ and $s\left(f_{i}\right)$ were responses (in spike counts/stimulus) to frequency $f_{i}$ when it was deviant or standard, respectively. The amount of SSA for both frequencies (Common SSA index, CSI) was calculated as $C S I=\left[d\left(f_{1}\right)+d\left(f_{2}\right)-s\left(f_{1}\right)-s\left(f_{2}\right)\right] /\left[d\left(f_{1}\right)+d\left(f_{2}\right)+s\left(f_{1}\right)+s\left(f_{2}\right)\right]$. These indices reflect the extent to which the response to a tone, when standard, was smaller than the response to the same tone, when deviant. The indices range between -1 to +1 , being positive if the response to a tone, when deviant, was greater than the response to the same tone, when standard.

\section{Reversible cooling AC deactivation}

We recorded well isolated single units from the MGB before, during and after deactivating the ipsilateral AC using the cooling technique. This technique enables the reversible deactivation of discrete regions of the brain (Carrasco and Lomber, 2009a;Carrasco and Lomber, 2009b;Lomber, 1999;Lomber and Malhotra, 2008;Coomber et al., 2010). It has been extensively used to study functional interactions between cortical areas (e.g., (Carrasco and Lomber, 2009a;Carrasco and Lomber, 2009b;Ghosh et al., 1994;Lomber, 1999;Lomber et al., 1999;Lomber and Malhotra, 2008)) and the corticofugal modulation of subcortical nuclei in various sensory systems. It is assumed that ipsilateral AC cooling deactivated all the descending inputs to the MGB, since corticofugal fibres terminating in this nucleus are entirely ipsilateral (Bajo et al., 1995;Bajo et al., 2010;Ojima and Rouiller, 2011).

To cool the AC, a $4 \mathrm{~mm}$ diameter cryoloop was fabricated by shaping a loop of 23gauge stainless steel hypodermic tubing to conform to the AC surface (Lomber et al., 1999). The loop was stereotaxically positioned over the AC, encompassing both the primary and secondary cortical field (Doron et al., 2002). The whole AC was 
deactivated in order to avoid specific effects due to partial deactivation. Cooling was achieved by pumping methanol cooled by dry ice through the cryoloop using a peristaltic pump. The temperature was monitored continuously by a microthermocouple (Omega HH506RA multiterm) attached to the union of the loop and accurately governed by controlling the flow of methanol, to get a loop temperature of $3^{\circ} \pm 1^{\circ} \mathrm{C}$ (Lomber et al., 1999). A stable cortical temperature was reached in $\sim 5$ min of initiating cooling. Recordings were started 5 min later to ensure deactivation of the deeper AC layers where the corticofugal projection to the MGB originates (mostly from layer VI with a minor proportion from layer V (Bajo et al., 1995;Bartlett et al., 2000;Kimura et al., 2007; Ojima and Rouiller, 2011). Cooling the cryoloop to $3 \pm 1^{\circ} \mathrm{C}$ is sufficient to deactivate all six layers of cortex beneath the cryoloop (Lomber et al., 1999) as it places the critical $20^{\circ} \mathrm{C}$ deactivation isotherm necessary to block synaptic transmission at the gray-white matter interface or deeper (Lomber et al., 1999). Such deactivation was confirmed in selected cases where AC responses were recorded up to $1000 \mu \mathrm{m}$ in depth, corresponding to layers V/VI in rat (Games and Winer, 1988) by the cessation of activity, as recorded by microelectrodes. The responses of the MGB neurons (FRAs and SSA) were recorded during 15 min of AC deactivation, after which the cryoloop pump was turned off. The normal AC surface temperature was regained in a few min, though cortical and MGB responses took longer to return to normal (Nakamoto et al., 2008). After $30 \mathrm{~min}$, the responses of the neurons returned to normal, since cooling disrupts neither the structural nor functional integrity of the cooled area (Lomber et al., 1999). The few neurons (3 out of 51) that did not recover to within 20\% of the pre-cooling maximum spike count were removed from all analyses. In some neurons a moderate higher firing rate was observed in the recovery, a rebound presumably due to a higher synaptic release probability during re-warming (Volgushev et al., 2004).

\section{Data analysis}

Statistical tests were performed using the non-parametric (two-sided) Wilcoxon signed rank test to test differences between distribution medians of varying conditions. Multiple comparisons were performed using Two-Way Repeated Measures ANOVAS (One factor repetition; repeated factor: condition). Correlation coefficients were 
performed using Pearson's correlation. The s.d. for the CSI of each individual neuron was calculated using 1000 repetition bootstrapping. Statistical tests were considered significant when $P<0.05$. The analysis and figures were done using Sigmaplot 11 (Systat Software, Inc) and Matlab (MathWorks).

\section{Histological verification of recording sites}

Each track was marked with electrolytic lesions for subsequent histological localization of the neurons recorded. At the end of the experiments the animals were perfused transcardially with $0.5 \% \mathrm{NaNO}_{3}$ in PBS followed by fixative (1\% paraformaldehyde and $1 \%$ glutaraldehyde in rat Ringer's solution). The brain tissue was sectioned in the transverse plane into $40 \mu \mathrm{m}$-thick sections that were Nissl stained with $0.1 \%$ cresyl violet. Recording sites were marked on standard sections from a rat brain atlas (Paxinos and Watson, 2005) and units were assigned to one of the three main divisions (ventral, dorsal and medial) of the MGB(Winer et al., 1999). 


\section{RESULTS}

\section{Effect of AC deactivation on SSA in the MGB}

To determine if the AC conveys SSA to the MGB neurons, we recorded the responses of 51 well isolated single units in the MGB, before, during and after reversibly deactivating the AC by cooling. To elicit SSA in the MGB neurons we used trains of two different pure tone stimuli in an oddball paradigm $\left(f_{1}\right.$ and $f_{2} ; 400$ stimulus presentations in two blocks; Fig. 1), presenting each tone with different probability of occurrence in the sequence (90\%, standard tone; 10\%, deviant tone). We used the stimulation conditions that elicited the most SSA in the MGB neurons (a frequency ratio of 0.141 octaves presented at a rate of $4 \mathrm{~Hz}$; (Antunes et al., 2010). To quantify SSA, we calculated the SI(fi) and CSI indices. These indices reflect the extent to which the response to a tone, when standard, was smaller than the response to the same tone, when deviant. The indices range between -1 to +1 , being positive if the response to a tone, when deviant, was greater than the response to the same tone, when standard (Compare units that had a stronger response to the deviant, i.e., showed SSA, in Fig. 1 with unit that had a similar response to both stimuli, i.e., did not show SSA, in Fig. 2m-x). Here, we found a similar distribution of values across the population to that found in our previous work, for the same set of conditions (Antunes et al., 2010).

All but three neurons showed full recovery after AC deactivation (48 out of 51; e.g., Figs. 1-4); these 3 neurons were excluded from subsequent analysis. Of the 48 neurons recorded, 30 demonstrated SSA (CSI > 0.18, Antunes et al., 2010). Our main finding is that these neurons had significant SSA levels during cortical deactivation (Figs. 1, 2a-l and 4). However, other response properties of the MGB neurons that we tested simultaneously, changed significantly under AC deactivation, such as: spectral response patterns (see FRAs on Figs. 1 and 2), spontaneous activity (the units in Fig. 1, 
reduced their spontaneous activity; the unit in Fig. 2a-l, augmented its spontaneous activity); firing rate (the units in Figs. 1 and 2m-x were suppressed; the unit in Fig. 2a-l was facilitated; Fig. 5); and latency (Fig. 6). We will analyse in detail the changes in firing rate and latency, after describing the effects of AC deactivation on SSA.

Neurons that showed SSA had a stronger response to the deviant than to the standard stimulus under all conditions (warm, cool and recovery) (Figs. 1 and 2a-l; similar CSI value in all conditions for all neurons). Neurons that did not show SSA maintained a similar response to both stimuli (Fig. 2m-x). There were no significant differences between the median CSI for the whole population when the AC was active and when it was deactivated (median CSI: 0.31, both conditions; Wilcoxon signed rank test, between warm and cool conditions: $n=37, Z=-1.290, P=0.2$; Fig. 4a). Eleven neurons were not included in the previous analysis because it was not possible to determine their CSI value for the cooling condition: 7 of these neurons because they ceased firing during cooling; and 4 neurons because they were suppressed to one of the frequencies of the pair chosen in the warm condition and therefore had an undefined SI value for this frequency. There were no significant differences between the median CSI during warm and recovery conditions (median CSI: 0.27 and 0.25, respectively; Wilcoxon signed rank test between warm and recovery conditions: $n=48, \mathrm{Z}=-1.313, P$ $=0.191$; this analysis included the 7 neurons that ceased firing and the 4 neurons that were suppressed to one of the frequencies during cooling). The overall distribution of CSI values in the population of neurons that were active during AC deactivation to both frequencies ( $n=37$, Fig. 4a) was similar for the three conditions (Fig. 4a).

To analyse if there were significant differences between the CSI values of individual neurons in the different conditions, we used the bootstrap method over 1000 randomisations to estimate the standard deviation (s.d.) of the CSI value in the warm 
condition, for each neuron (Fig. 4b). No significant differences were found between the CSI values in the different conditions for the majority of neurons: The CSI values during cooling and recovery for 42 of the 48 neurons are within the s.d determined for the CSI value in the warm condition. Of the 5 remaining neurons, 3 had a CSI value for one of the conditions within 2 s.d. of the CSI in the warm condition (units 1 and 30 for the cool condition; unit 24 for the recovery condition; Fig. 4b). Only 2 of these neurons had a significantly lower CSI value during the cool condition (outside 3 s.d. of the CSI in the warm condition; units 40 and 48 in the cool condition; asterisks on Fig. 4b; see unit 40 in Fig. 2a-l). Even though, these neurons retained SSA during AC deactivation $(\mathrm{CSI}=0.39$ and 0.68 , respectively).

\section{Effect of AC deactivation on the temporal dynamics of SSA}

To look for a possible alteration in the dynamics of SSA with cortical deactivation, we calculated the average population firing rate in response to the standard stimulus across trials, before, during and after cortical deactivation (Fig. 4c, d). Since these dynamics will be influenced by all neurons in the population, we analysed separately the responses of neurons with and without SSA $(\mathrm{CSI} \leq 0.18$ and $\mathrm{CSI}>0.18$, respectively; Antunes et al., 2010) to the standard stimulus (Fig. 4c, d). As the neurons did not adapt to the deviant stimulus, they maintained their response to this stimulus through the trials in each condition (Fig. 4e).

The responses to the standard of neurons with SSA declined strongly after the first few trials, under all conditions (Fig. 4c). Although these neurons reduced their firing rate during AC deactivation (cool, blue trace), they recovered to the rate exhibited before deactivation (warm, red trace) after AC rewarming (recovery, yellow trace), and maintained similar dynamics of adaptation under all conditions (Fig. 4c). Indeed, the 
model that provided the best fit to these responses in the warm condition when the AC was active, explained a high proportion of the adaptation, and yielded similar results in the three conditions (Polynomial inverse model: $f=y_{0}+(a / x)+\left(b / x^{2}\right) ; r^{2}=0.61,0.53$, 0.55, warm, cool, and recovery, respectively; $P<0.0001$, all conditions). Hence, the neurons showing SSA maintained a similar adaptation dynamics when the AC was deactivated to that when it was active. This demonstrates that the AC exerts no significant effect on the SSA exhibited by the majority of MGB neurons and on its dynamics over time, and that SSA in this nucleus is not inherited from the AC. The AC would rather modulate the general response properties of MGB neurons in a gain control manner. Such modulation would affect in a similar way both stimuli and may explain the absence of an effect on the SSA exhibited in the MGB.

The responses of neurons without SSA showed a minor decrement in firing rate after the first trials in the warm condition that was lost during AC deactivation (Fig. 4d; the variance explained by the same polynomial inverse model described above was close to zero in the warm condition: $r^{2}=0.09, P<0.001$; the model was not significant in cool and recovery conditions: $P=0.378$ and 0.516 , respectively). The overall firing rate to the standard of these neurons was strongly reduced with cortical deactivation in relation to the warm condition. This effect was less pronounced in the neurons that show SSA (compare Fig. 4c and d). This suggests that the AC exerts a differential modulatory effect on the discharge rate of neurons exhibiting different levels of SSA.

\section{Effect of AC deactivation on the firing rate of MGB neurons}

In the whole population, the average firing rate evoked by both stimuli was significantly lower while the AC was cooled and deactivated (only 9 out of 48 neurons augmented their firing rate; e.g. Fig. 2a-1) than while it was active ( $n=48$; median firing rate to the 
deviant: 1.34 and 0.54 spikes/stimulus, warm and cool conditions, respectively; median firing rate to the standard: 0.85 and 0.16 spikes/stimulus, warm and cool conditions, respectively; Wilcoxon signed rank test, between the warm and cool conditions: $\mathrm{Z}=$ 4.913 and -4.667 , deviant and standard, respectively, $P<0.001$, both stimuli; Fig. 5a, c; e.g. Figs. 1, 2m-x and 3). Neurons recovered their initial firing rate after AC rewarming ( $n=48$; median firing rate to the deviant: 1.34 spikes/stimulus, both conditions; median firing rate to the standard: 0.85 and 0.67 spikes/stimulus, warm and recovery conditions, respectively; Wilcoxon signed rank test, between the warm and recovery conditions: $\mathrm{Z}$ $=-0.369$ and $-0.944, P=0.716$ and 0.348 , deviant and standard, respectively; Fig. 5b, c; e.g. Figs. 1-3).

Although significant in both populations, the reduction in firing rate with AC deactivation was stronger in the population of neurons without SSA $(n=18$; median firing rate to the deviant: 1.5 and 0.43 spikes/stimulus, warm and cool conditions, respectively; median firing rate to the standard: 1.56 and 0.52 spikes/stimulus, warm and cool conditions, respectively; Wilcoxon signed rank test, between the warm and cool conditions: $\mathrm{Z}=-3.72, P<0.001$, both stimuli), than on neurons with SSA $(n=30$; median firing rate to the deviant: 1.16 and 0.54 spikes/stimulus, warm and cool conditions, respectively; median firing rate to the standard: 0.4 and 0.14 spikes/stimulus, warm and cool conditions, respectively; Wilcoxon signed rank test, between the warm and cool conditions: $\mathrm{Z}=-3.22$ and -2.56 , deviant and standard, respectively, $P<0.01$, both stimuli).

To analyse the effect of AC deactivation on the discharge rate of neurons across SSA levels, we plotted the CSI versus the difference in firing rate between the warm and cool conditions for each neuron (Fig. 5d, e; standard and deviant, respectively): positive values for this difference indicate a reduction in firing rate with AC 
deactivation; and negative values an increment (Fig. 5d, e; values above and below the horizontal line at the origin, respectively). This difference in firing rate was inversely correlated with CSI for both stimuli (Pearson: $r=-0.645$ and -0.496 , standard and deviant, respectively; $P<0.001, n=48$, both stimuli; Fig. 5d, e). Although the correlation coefficient is higher for the standard than for the deviant stimulus, this difference is not significant since the slopes of the standard and deviant regression lines are not significantly different from each other (ANCOVA: $F_{(1,92)}=1.89, P=0.172$, main effect of stimuli; $F_{(1,92)}=43.27, P=0$, main effect of CSI; and $F_{(1,92)}=0.23, P=$ 0.634, interaction; $n=48$; Fig. 5d, e). Neurons without SSA were suppressed during AC deactivation to both stimuli (Fig. 5d, e; CSI values around zero, vertical dashed line); then, as the CSI of the neurons increased, i.e., showed greater SSA, they became less suppressed (Fig. 5d, e; standard and deviant, respectively). Furthermore, some highly adapting neurons were facilitated during AC deactivation to both stimuli (Fig. 5d, e; e.g. Fig. 2a-l). This suggests that the AC has a differentially effect upon the discharge pattern of neurons exhibiting different levels of SSA; neurons without SSA are mainly facilitated, but some neurons with high SSA are suppressed by the AC.

We localized 45 (out of 48) neurons to one of the three main MGB subdivisions: 24 neurons were localized to the MGD, 12 to the MGV and 9 to the MGM (Fig. 5d, e; green, blue and red dots, respectively; e.g. Figs. 1a-l and 2a-l, units from the MGM; Fig. 1m-z, unit from the MGD; Fig. 2m-x, unit from the MGV). SSA was stronger in the medial subdivision; intermediate in the dorsal and weakest in the ventral subdivisions (Mean CSI 0.65, 0.36 and 0.1, respectively; $c f$. ., Antunes et al., 2010). Our sample is biased towards the non-lemniscal subdivisions (total of 33 units from the MGD and MGM) where SSA is stronger and neurons show predominantly non-V shaped type FRAS. Although there was a significant effect of AC deactivation on the firing rate of 
this population, there was no effect of subdivision nor an interaction between condition and subdivision ( $n=45$; Two way repeated measures ANOVA, for the responses to the deviants: $F_{(1,42)}=21.95, P<0.001$, main effect of condition; $F_{(2,42)}=2.96, P=0.06$, main effect of subdivision; and $F_{(2,42)}=0.12, P=0.89$, interaction; Two way repeated measures ANOVA, for the responses to the standards: $F_{(1.42)}=22.88, P<0.001$, main effect of condition; $F_{(2,42)}=2.89, P=0.07$, main effect of subdivision; and $F_{(2,42)}=1.06$, $P=0.36$, interaction). These results are consistent with the fact that the MGD shows a range of firing rate changes that extends through the CSI range. Moreover, the MGM has also some neurons that were facilitated whereas others were suppressed. This lack of a correlation between subdivisions and the firing rate changes suggests that the degree of SSA exhibited by the MGB neurons determines the modulatory effect exerted by the AC on their discharge rate rather than their localization within subdivisions.

\section{Effect of AC deactivation on the latency of MGB neurons}

The population of active neurons during AC deactivation showed a significantly longer median latency (mean first-spike latency) than before deactivation ( $n=41$; median latencies to the deviant: 17.1 and $19.5 \mathrm{~ms}$, warm and cool condition, respectively; median latency to the standard: $17.5 \mathrm{~ms}$ and $21.3 \mathrm{~ms}$, warm and cool condition, respectively; Wilcoxon signed rank test, between warm and cool conditions: $Z=3.764$ and 4.244, deviant and standard, respectively; $P<0.001$, both stimuli; this analysis included the 4 neurons that were suppressed to one of the frequencies during cooling since they were active and responded to the other frequency; Fig. 6a, c). This lengthening of latency caused by AC deactivation indicates that the AC modulates the latency of the MGB neurons, shortening their latencies to both stimuli. The neurons recovered their latencies after AC deactivation: no differences were found between their 
initial latencies and those after AC rewarming and reactivation $(n=48$; median latencies to the deviant: 17.4 and $18.5 \mathrm{~ms}$, warm and recovery condition, respectively; median latencies to the standard: 19.3 and $19.7 \mathrm{~ms}$, warm and recovery condition, respectively; Wilcoxon signed rank test, between warm and recovery conditions: $\mathrm{Z}=$ 0.697 and $Z=0, P=0.489$ and $P=0.996$, deviant and standard, respectively; this analysis included the neurons that were inactive during cooling; Fig. 6b, d).

This analysis also showed that the latency of the responses to the deviant was significantly shorter than that to the standard, before AC deactivation (Median latency: 17.1 and 17.5 ms, respectively; Wilcoxon signed rank test: $n=41, Z=4.879, P<0.001$; Fig. 6c; cf., (Antunes et al., 2010)); and that this latency difference was maintained during AC deactivation (Median latency: 19.5 and 21.3 ms, deviant and standard, respectively; Wilcoxon signed rank test: $n=41, Z=2.041, P=0.04$; Fig. 6c).This indicates that the AC is not generating the latency gap in the responses to the standard versus the deviant exhibited by the MGB neurons.

To further evaluate if the AC deactivation had a differential effect on the latency across SSA levels, we plotted the CSI of the neurons versus the difference in the mean first-spike latency between the warm and cool conditions (Fig. 6e, f; standard and deviant, respectively; $n=41$, active neurons during cooling): negative values indicate a lengthening in the latency during AC deactivation; and positive values a shortening (Fig. 6e, f; below and above the horizontal line at the origin, respectively). This difference in latency was significantly and positively correlated with CSI, for the responses to the standard stimulus (Pearson: $r=0.319, P=0.042$; Fig. 6e). The latency of the responses to the deviant stimulus showed the same trend, but the correlation was not significant (Pearson: $r=0.262, \mathrm{P}=0.099$; Fig. $6 \mathrm{f}$ ). The slopes of the standard and deviant regression lines are not significantly different from each other indicating that 
there is no significant difference between the correlation coefficient obtained for both stimuli (ANCOVA: $F_{(1,78)}=0.34, P=0.561$, main effect of stimuli; $F_{(1,78)}=7.14, P=$ 0.009, main effect of CSI; and $F_{(1,78)}=0.05, P=0.829$, interaction; $n=41$; Fig. 6e, f). This analysis showed that all neurons not showing SSA $(\mathrm{CSI} \leq 0.18)$ had a longer latency during AC deactivation to both stimuli (Fig. 6e, f; Wilcoxon signed rank test, between warm and cool conditions: $n=15, \mathrm{Z}=2.95$ and $\mathrm{Z}=3.408, P=0.002$ and $P<$ 0.001, deviant and standard, respectively). By contrast, the few neurons that had a shorter latency during AC deactivation, showed some level of adaptation (CSI > 0.18; Fig. 6e, f; dots above the horizontal line); but still, the median latency of the population of neurons with SSA was significantly longer during AC deactivation to both stimuli (Wilcoxon signed rank test, between control and cooling, CSI > 0.18: $n=26, \mathrm{Z}=2.451$ and $\mathrm{Z}=2.578, P=0.015$ and $P=0.01$, deviant and standard, respectively). The higher warm-cool differences were exhibited by neurons with zero or intermediate CSI values $(<0.45)$ from the MGV subdivision (Fig. 6e, f; blue dots). This indicates that the MGV is the subdivision in which latency depends strongest on modulation from the AC.

Although there was a significant effect of AC deactivation on the latencies in the population of the neurons that were localized, there was no effect of subdivision nor an interaction between condition and subdivision (Two way repeated measures ANOVA, for the responses to the deviant: $F_{(1,36)}=4.520, P=0.04$, main effect of condition; $F_{(2,36)}=2.103, P=0.137$, main effect of subdivision; and $F_{(2,36)}=0.821, P=0.448$, interaction; Two way repeated measures ANOVA, for the responses to the standard: $F_{(1,36)}=6.788, P=0.013$, main effect of condition; $F_{(2,36)}=1.732, P=0.191$, main effect of subdivision; and $F_{(2,36)}=0.64, P=0.533$, interaction). 


\section{DISCUSSION}

In this study, we reversibly deactivated the AC using the cooling technique to silence its neurons and the descending (ipsilateral) projections to the auditory thalamus, in order to examine if the AC exerts an effect on the SSA exhibited by MGB neurons. Overall, our results demonstrate that AC deactivation produced non-significant changes in the mean SSA levels over the population and small changes in the individual neurons in the MGB. Furthermore, the temporal dynamics of SSA in the MGB were not affected by AC deactivation. These findings demonstrate that SSA exhibited by MGB neurons is not a property inherited from the AC but instead can be inherited from lower levels such as the inferior colliculus and/or generated de novo in the MGB. This is in agreement with the fact that high-SSA neurons in the IC and MGB are mainly onset responders with short latencies (Malmierca et al., 2009;Perez-Gonzalez et al., 2005). We suggest that SSA generated at lower levels, can be transmitted in a bottom-up manner and likely be modulated intrinsically at each level of the auditory pathway. Such bottom-up transmission of SSA would enable each level of the auditory system to take the responses of the previous level in order to eliminate as much statistical redundancy as possible (Schwartz and Simoncelli, 2001). In view of this, synaptic depression can be a potential mechanism underlying SSA (Chung et al., 2002;Rothman et al., 2009), since it is input-specific and causes the responses of a neuron to depend on the previous history of afferent firing, enhancing its sensitivity to non-repeated stimuli (Abbott et al., 1997;Rothman et al., 2009). Moreover, it is compatible with the participation of additional mechanisms linked to neuronal intrinsic properties (Abolafia et al., 2010), that can transform SSA at each level of the auditory pathway.

Our data also demonstrate that in contrast to SSA the response patterns of the MGB neurons, such as their FRAs, spontaneous activity, discharge rate and latencies, 
were significantly altered with AC deactivation. Such changes occurred in all neurons, although to different degrees in the different neurons, demonstrating that our results are genuine and not the consequence of technical artefacts. Furthermore, these findings confirm previous studies that used the cooling technique (Palmer et al., 2007;Ryugo and Weinberger, 1976;Villa and Abeles, 1990;Villa et al., 1991;Villa et al., 1999) and electrical stimulation (He, 2003a;He, 2003b;Ojima and Rouiller, 2011) , and corroborate the strong corticofugal modulation that the MGB like other subcortical nuclei receive (Bajo et al., 2010;Malmierca and Ryugo, 2011;Nakamoto et al., 2008;Nakamoto et al., 2010;Villa and Abeles, 1990;Villa et al., 1991;Villa et al., 1999; Yu et al., 2009), as also demonstrated in the visual (Rushmore et al., 2005; Sillito et al., 1994) and somatosensory systems (Ghosh et al., 1994). Here, we demonstrate that such corticofugal modulation does not account significantly for the SSA exhibited in the MGB neurons, but rather, modulates the discharge rate of these neurons in a gain control manner, affecting similarly the responses to the standard and the deviant stimulus. As a result, the degree of SSA quantified by a ratio of driven rates, was largely unaffected by cooling. Indeed, recent studies suggest that the corticofugal system can participate in a gain control process that leads to improved coding of salient stimuli (Robinson and McAlpine, 2009), and possibly underlies auditory attention (He, 2003a) and learning-induced plasticity (Bajo et al., 2010). Our results are consistent with the role of the corticofugal pathway in scaling the sensitivity of the MGB neurons to its driving inputs in a gain control fashion.

Although SSA in the MGB is only weakly affected by cortical deactivation, we did find a highly significant relationship between SSA and changes elicited by cooling. Our findings demonstrate that the corticofugal modulation of the discharge rate of MGB neurons vary significantly with the SSA level that they exhibited, such that the 
facilitation exerted by the AC on the MGB neurons reduces as the SSA increases, with some high adapting neurons being suppressed (Fig. 5). This relation is not dependent on the anatomical subdivision to which the MGB neurons belong but on the SSA they exhibit, linking this property to the type of corticofugal modulation that they receive. Since some high SSA neurons from the non-lemniscal MGB received suppressive influence from the corticofugal pathway, inhibition is a possible mechanism underlying such modulation, via the thalamic reticular nucleus (TRN; (He, 2003a;Yu et al., 2009)), a nucleus that also exhibits SSA (Yu et al., 2009). Our results show that the possible inhibition driven by the corticofugal pathway does not underlie SSA on the MGB neurons. Hence, if inhibition plays a role in SSA as suggested in previous studies (Eytan et al., 2003;Richardson et al., 2011;Yu et al., 2009) other pathways should be involved, such as those coming from the IC (Peruzzi et al., 1997) as well as the TRN-MGB connections themselves (Yu et al., 2009).

Furthermore, we demonstrate that the AC modulates the latency of the MGB neurons, mainly shortening their latencies, as previously shown in some subcortical neurons using electrical stimulation of AC (Luo et al., 2008). This effect becomes less pronounced as the neuronal adaptation increases. The slight latency shift that the strong adapting neurons from the thalamus and the midbrain with the shortest latencies $(<25$ ms) exhibit comparatively to the weaker or non-adapting ones (Antunes et al., 2010;Malmierca et al., 2009) may be due to a weaker cortical influence that mainly shortens the latency of the MGB neurons. The MGB neurons maintained a shorter latency to the deviant than to the standard (cf., Antunes et al.,(Antunes et al., 2010)) during cortical deactivation, demonstrating that this latency phenomenon is not of cortical origin. 
The fact that the non-adapting neurons are mainly facilitated and their latencies shortened by corticofugal modulation can be achieved by direct excitation from the AC and/or by a release of inhibitory inputs coming from neurons in the thalamus and in its input stations (IC-MGB projection; (Bartlett et al., 2000;Peruzzi et al., 1997)) via TRN inhibition on these inhibitory inputs.

Our findings together demonstrate that the AC and the corticofugal pathway provide a gating or gain control mechanism (He, 2003a;Robinson and McAlpine, 2009;Villa and Abeles, 1990;Villa et al., 1991;Yu et al., 2009) modulating the general responses of the MGB neurons, without changing significantly SSA in this thalamic nucleus. However, a subset of neurons had their acoustic responsiveness eliminated with cortical deactivation (4 in the MGD; 2 in the MGV; the other was not histologically localized). These data are in agreement with the drivers and modulators hypothesis proposed originally by Sherman and Guillery (Guillery, 1995;Sherman and Guillery, 1998). The main corticofugal projections to the MGB arise from layer VI neurons whose terminals are mostly small and modulatory (Bajo et al., 1995;Bartlett et al., 2000;Ojima and Rouiller, 2011;Ojima, 1994;Rouiller and Welker, 1991). In addition, a few pyramidal neurons from layer $\mathrm{V}$ with large terminal buttons of the driver type project to the MGD and MGV subdivisions (Bajo et al., 1995;Bartlett et al., 2000;Ojima and Rouiller, 2011;Ojima, 1994;Rouiller and Welker, 1991). These seven neurons that ceased firing during cooling had none or very low levels of SSA (CSI < 0.28), agreeing with our main result that SSA in the MGB is not inherited from the AC. In conclusion, we demonstrate that the corticofugal pathway exerts a gain control modulation of the responses of the MGB neurons but does not drive or transform SSA in this nucleus. This property could therefore be generated in a bottom- 
up fashion throughout the auditory pathway, as a pre-attentive gating involved in reducing sensory input to behaviourally relevant aspects.

\section{Acknowledgements:}

We are most grateful to Alan Palmer for his assistance in setting up the cooling technique. We also thank Drs. Israel Nelken, Daniel Llano, Adrian Rees, Alan Palmer and Xiaoqin Wang for their critical and valuable comments on a previous version of the manuscript.

Financial support was provided by the Spanish MEC (BFU2009-07286), EU (EUI200904083) and JCYL-UE (GR221) to MSM. FMA held a fellowship from the Spanish MEC (BES-2007-15642).

FMA performed experiments, collected and analyzed data and wrote the manuscript; MSM designed the experiments, wrote the manuscript and supervised the project. All authors discussed the results and implications and commented on the manuscript at all stages. 


\section{FIGURE LEGENDS}

Figure 1: Examples of single unit responses in the MGB before, during and after AC deactivation. (a-c) The frequency response area (FRA) of a neuron localized to the medial subdivision (MGM) in the warm, cool and recovery conditions. (d-f) Responses of the neuron to the oddball paradigm as dot rasters, which plot individual spikes (red and blue dots, to the deviant and standard, respectively) in each of the three conditions, for the first block ( $f_{1} / f_{2}$ as standard/deviant) and (g-i) second block $\left(f_{2} / f_{1}\right.$ as standard/deviant) of stimulus presentations (stacked along the y-axis: trial \#, 400 trials each block). The time between trials (250 ms; x-axis) corresponds to the stimulus repetition rate ( $4 \mathrm{~Hz}$ rate; with $75 \mathrm{~ms}$ stimulus duration, black horizontal lines under the plots). (j-l) PSTHs show the number of spikes/stimulus (bin duration: 3ms) averaged over the two blocks [(f1+f2)/2; blue line is standard, red line is deviant]. The CSI calculated for each condition is noted as an insert on the PSTHs. (m-x) responses of another neuron localized to the dorsal subdivision (MGD), presented as in a-l.

Figure 2: Examples of single unit responses in the MGB before, during and after AC deactivation. (a-c) The frequency response areas (FRA) in the three conditions of a neuron localized to the MGM that was facilitated during AC deactivation.(d-f) Responses of the neuron to the oddball paradigm as dot rasters, which plot individual spikes (red and blue dots, to the deviant and standard, respectively) in each of the three conditions, for the first block ( $f_{1} / f_{2}$ as standard/deviant) and (g-i) second block $\left(f_{2} / f_{1}\right.$ as standard/deviant) of stimulus presentations (stacked along the y-axis: trial \#, 400 trials each block). The time between trials (250 ms; x-axis) corresponds to the stimulus repetition rate ( $4 \mathrm{~Hz}$ rate; with $75 \mathrm{~ms}$ stimulus duration, black horizontal lines under the plots). (j-l) PSTHs show the number of spikes/stimulus (bin duration: 3ms) averaged over the two blocks [(f1+f2)/2; blue line is standard, red line is deviant]. The CSI calculated for each condition is noted as an insert on the PSTHs. (m-x) responses of another neuron localized to the ventral subdivision (MGV) with a V-shaped type FRA that did not show SSA (similar response to both stimuli: CSI $\sim 0$ ). 
Figure 3: Stages of the AC deactivation cycle. (a) Temperature changes recorded at the cooling loop during a complete deactivation cycle. (b) PSTHs show the activity of the units that Fig. 1a-l and (c) Fig. 1m-x show in the five stages of the cycle. Note the strong decrease in activity during the cool condition compared with the activity in the warm and recovery conditions, and the gradual changes during the transitional stages between conditions.

Figure 4: SSA quantification and its time course of adaptation in the MGB neurons before, during and after AC deactivation. (a) Box plots showing the distribution of CSI values in the warm (red), cool (blue) and recovery conditions (orange), for the population of active neurons that responded to both frequencies during cooling $(n=37)$. The continuous and dashed horizontal lines across the plots represent the median and mean values, respectively. (b) CSI values for each individual neuron in the warm (red dots), cool (blue dots) and recovery (orange dots) conditions. Of the 48 neurons only 37 had a CSI value for the cool condition. Error bars represent SD calculated using bootstrapping. Asterisks indicate neurons that had a CSI value in the cool condition outside 2 SD of the bootstrapped sample. (c) Average population firing rate (spikes/stimulus) in response to the standard stimulus of the neurons with adaptation $(\mathrm{CSI}>0.18)$ and $(\mathbf{d})$ without adaptation $(\mathrm{CSI} \leq 0.18)$ versus trial number, in the warm (red line), cool (blue line) and recovery (orange line) conditions. (e) Responses to the deviant stimulus for all neurons, presented as in c-d.

Figure 5: Effect of AC deactivation on the firing rate of MGB neurons. (a) Scatterplots of the responses of all neurons (spikes/stimulus, $n=48$ ) to the deviant (red dots) and standard stimulus (blue dots) in the warm versus cool condition $(P<0.001$, both stimuli, Wilcoxon signed rank test), and (b) warm versus recovery condition (n.s., both stimuli, Wilcoxon signed rank test). (c) Box plots showing the distribution of firing rate values in the whole population $(n=48)$ in the warm, cool and recovery conditions, in response to the standard (blue plots) and the deviant stimulus (red plots). (d) Scatterplots of the CSI (warm condition) versus the difference in firing rate between the warm and cool conditions (spikes/stimulus difference) in response to the standard, and (e) in response to the deviant stimulus, for each neuron. Blue, green and red dots 
represent the neurons that were localized to the ventral $(n=12)$, dorsal $(n=24)$ and medial $(n=9)$ subdivisions of the MGB, respectively $(n=45)$. Positive values indicate a reduction in firing rate with AC deactivation; and negative values an increment (above and bellow the horizontal line at the origin, respectively).

Figure 6: Effect of AC deactivation on the latency of MGB neurons. (a) Scatterplots showing the mean first spike latencies (latency, ms) of the active neurons during cooling ( $n=41)$ to the deviant (red dots) and standard stimulus (blue dots) in the warm versus cool condition ( $P<0.001$, both stimuli, Wilcoxon signed rank test), and (b) the latencies of all neurons $(n=48)$ in the warm versus recovery conditions (n.s., both stimuli, Wilcoxon signed rank test). (c) Box plots showing the distribution of latency values in response to the standard (blue plots) and the deviant stimulus (red plots) in the warm and cool conditions for the population of active neurons during cooling $(n=41)$, and (d) in the warm and recovery conditions for all neurons $(n=48)$. (e) Scatterplots of the CSI (warm condition) versus the difference in latency between the warm and cool conditions (latency difference) in response to the standard, and (f) in response to the deviant stimulus, for each neuron. Blue, green and red dots represent the neurons that were localized to the ventral $(n=12)$, dorsal $(n=24)$ and medial $(n=9)$ subdivisions of the MGB, respectively $(n=45)$. Positive values indicate a decrease in latency with AC deactivation; and negative values an increase (above and bellow the horizontal line at the origin, respectively). 


\section{Reference List}

Abbott LF, Varela JA, Sen K, Nelson SB (1997) Synaptic depression and cortical gain control. Science 275:220-224.

Abolafia JM, Vergara R, Arnold MM, Reig R, Sanchez-Vives MV (2011) Cortical Auditory Adaptation in the Awake Rat and the Role of Potassium Currents. Cereb Cortex 21:977-990.

Antunes FM, Malmierca MS (2011) Top-Down Modulation of Stimulus-Specific Adaptation in the Auditory Thalamus. ARO Abst. pp 93-94.

Antunes FM, Nelken I, Covey E, Malmierca MS (2010) Stimulus-specific adaptation in the auditory thalamus of the anesthetized rat. PLoS One 5:e14071.

Bajo VM, Nodal FR, Moore DR, King AJ (2010) The descending corticocollicular pathway mediates learning-induced auditory plasticity. Nat Neurosci 13:253260.

Bajo VM, Rouiller EM, Welker E, Clarke S, Villa AE, De RY, De RF (1995) Morphology and spatial distribution of corticothalamic terminals originating from the cat auditory cortex. Hear Res 83:161-174.

Bartlett EL, Stark JM, Guillery RW, Smith PH (2000) Comparison of the fine structure of cortical and collicular terminals in the rat medial geniculate body. Neuroscience 100:811-828.

Carrasco A, Lomber SG (2009b) Evidence for hierarchical processing in cat auditory cortex: nonreciprocal influence of primary auditory cortex on the posterior auditory field. J Neurosci 29:14323-14333.

Carrasco A, Lomber SG (2009a) Differential modulatory influences between primary auditory cortex and the anterior auditory field. J Neurosci 29:8350-8362.

Chung S, Li X, Nelson SB (2002) Short-term depression at thalamocortical synapses contributes to rapid adaptation of cortical sensory responses in vivo. Neuron 34:437-446.

Coomber B, Edwards E, Shackleton T.M., Pamer AR (2010) Cortical inactivation by cooling in smaller animals. pp 99.

Doron NN, LeDoux JE, Semple MN (2002) Redefining the tonotopic core of rat auditory cortex: physiological evidence for a posterior field. J Comp Neurol 453:345360.

Eytan D, Brenner N, Marom S (2003) Selective adaptation in networks of cortical neurons. J Neurosci 23:9349-9356.

Games KD, Winer JA (1988) Layer V in rat auditory cortex: projections to the inferior colliculus and contralateral cortex. Hear Res 34:1-25. 
Ghosh S, Murray GM, Turman AB, Rowe MJ (1994) Corticothalamic influences on transmission of tactile information in the ventroposterolateral thalamus of the cat: effect of reversible inactivation of somatosensory cortical areas I and II. Exp Brain Res 100:276-286.

Guillery RW (1995) Anatomical evidence concerning the role of the thalamus in corticocortical communication: a brief review. J Anat 187 ( Pt 3):583-592.

Gutfreund Y, Knudsen EI (2006) Adaptation in the auditory space map of the barn owl. J Neurophysiol 96:813-825.

He J (2003a) Corticofugal modulation of the auditory thalamus. Exp Brain Res 153:579590.

He J (2003b) Corticofugal modulation on both ON and OFF responses in the nonlemniscal auditory thalamus of the guinea pig. J Neurophysiol 89:367-381.

Kimura A, Donishi T, Okamoto K, Imbe H, Tamai Y (2007) Efferent connections of the ventral auditory area in the rat cortex: implications for auditory processing related to emotion. Eur J Neurosci 25:2819-2834.

Kimura A, Donishi T, Okamoto K, Tamai Y (2005) Topography of projections from the primary and non-primary auditory cortical areas to the medial geniculate body and thalamic reticular nucleus in the rat. Neuroscience 135:1325-1342.

Lee CC, Winer JA (2005) Principles governing auditory cortex connections. Cereb Cortex 15:1804-1814.

Lomber SG (1999) The advantages and limitations of permanent or reversible deactivation techniques in the assessment of neural function. J Neurosci Methods 86:109-117.

Lomber SG, Malhotra S (2008) Double dissociation of 'what' and 'where' processing in auditory cortex. Nat Neurosci 11:609-616.

Lomber SG, Payne BR, Horel JA (1999) The cryoloop: an adaptable reversible cooling deactivation method for behavioral or electrophysiological assessment of neural function. J Neurosci Methods 86:179-194.

Luo F, Wang Q, Kashani A, Yan J (2008) Corticofugal modulation of initial sound processing in the brain. J Neurosci 28:11615-11621.

Malmierca MS, Cristaudo S, Perez-Gonzalez D, Covey E (2009) Stimulus-specific adaptation in the inferior colliculus of the anesthetized rat. J Neurosci 29:54835493.

Malmierca MS, Hernandez O, Rees A (2005) Intercollicular commissural projections modulate neuronal responses in the inferior colliculus. Eur J Neurosci 21:27012710. 
Malmierca MS, Izquierdo MA, Cristaudo S, Hernandez O, Perez-Gonzalez D, Covey E, Oliver DL (2008) A discontinuous tonotopic organization in the inferior colliculus of the rat. J Neurosci 28:4767-4776.

Malmierca MS, Ryugo DK (2011) Descending Connections of Auditory Cortex to the midbrain and Brian Stem. In: The Auditory Cortex (Winer J.A., Schreiner C.E., eds), pp 189-208. New York: Springer.

Merryll EG, Ainswoth A (1972) Glass-coated platinum coated tungsten microelectrodes. Med and Biol Eng 10:662-672.

Nakamoto KT, Jones SJ, Palmer AR (2008) Descending projections from auditory cortex modulate sensitivity in the midbrain to cues for spatial position. J Neurophysiol 99:2347-2356.

Nakamoto KT, Shackleton TM, Palmer AR (2010) Responses in the inferior colliculus of the guinea pig to concurrent harmonic series and the effect of inactivation of descending controls. J Neurophysiol 103:2050-2061.

Nelken I (2004) Processing of complex stimuli and natural scenes in the auditory cortex. Curr Opin Neurobiol 14:474-480.

Nelken I, Ulanovsky N (2007) Mismatch negativity and stimulus-specific adaptation in animal models. Journal of Psycophysiology214-223.

Ojima H (1994) Terminal morphology and distribution of corticothalamic fibers originating from layers 5 and 6 of cat primary auditory cortex. Cereb Cortex 4:646-663.

Ojima H, Rouiller EM (2011) Auditory Cortical Projections to the Medial Geniculate Body. In: The Auditory Cortex (Winer J.A., Schreiner C.E., eds), pp 171-188. New York: Springer.

Palmer AR, Hall DA, Sumner C, Barrett DJ, Jones S, Nakamoto K, Moore DR (2007) Some investigations into non-passive listening. Hear Res 229:148-157.

Paxinos G, Watson C (2005) The Rat Brain in Stereotaxic Coordinates. Burlington: Elsevier-Academic Press.

Perez-Gonzalez D, Malmierca MS, Covey E (2005) Novelty detector neurons in the mammalian auditory midbrain. Eur J Neurosci 22:2879-2885.

Peruzzi D, Bartlett E, Smith PH, Oliver DL (1997) A monosynaptic GABAergic input from the inferior colliculus to the medial geniculate body in rat. J Neurosci 17:3766-3777.

Ranganath C, Rainer G (2003) Neural mechanisms for detecting and remembering novel events. Nat Rev Neurosci 4:193-202.

Reches A, Gutfreund Y (2008) Stimulus-specific adaptations in the gaze control system of the barn owl. J Neurosci 28:1523-1533. 
Reches A, Netser S, Gutfreund Y (2010) Interactions between stimulus-specific adaptation and visual auditory integration in the forebrain of the barn owl. $\mathrm{J}$ Neurosci 30:6991-6998.

Rees A (1990) A close-field sound system for auditory neurophysiology. J of Physiol 430:2.

Richardson BD, Ling LL, Uteshev VV, Caspary DM (2011) Extrasynaptic GABA(A) receptors and tonic inhibition in rat auditory thalamus. PLoS One 6:e16508.

Robinson BL, McAlpine D (2009) Gain control mechanisms in the auditory pathway. Curr Opin Neurobiol 19:402-407.

Rothman JS, Cathala L, Steuber V, Silver RA (2009) Synaptic depression enables neuronal gain control. Nature 457:1015-1018.

Rouiller EM, Welker E (1991) Morphology of corticothalamic terminals arising from the auditory cortex of the rat: a Phaseolus vulgaris-leucoagglutinin (PHA-L) tracing study. Hear Res 56:179-190.

Rouiller EM, Welker E (2000) A comparative analysis of the morphology of corticothalamic projections in mammals. Brain Res Bull 53:727-741.

Rushmore RJ, Payne BR, Lomber SG (2005) Functional impact of primary visual cortex deactivation on subcortical target structures in the thalamus and midbrain. $\mathrm{J}$ Comp Neurol 488:414-426.

Ryugo DK, Weinberger NM (1976) Corticofugal modulation of the medial geniculate body. Exp Neurol 51:377-391.

Schwartz O, Simoncelli EP (2001) Natural signal statistics and sensory gain control. Nat Neurosci 4:819-825.

Sherman SM, Guillery RW (1998) On the actions that one nerve cell can have on another: distinguishing "drivers" from "modulators". Proc Natl Acad Sci U S A 95:71217126.

Sillito AM, Jones HE, Gerstein GL, West DC (1994) Feature-linked synchronization of thalamic relay cell firing induced by feedback from the visual cortex. Nature 369:479-482.

Ulanovsky N, Las L, Farkas D, Nelken I (2004) Multiple time scales of adaptation in auditory cortex neurons. J Neurosci 24:10440-10453.

Ulanovsky N, Las L, Nelken I (2003) Processing of low-probability sounds by cortical neurons. Nat Neurosci 6:391-398.

Villa AE, Abeles M (1990) Evidence for spatiotemporal firing patterns within the auditory thalamus of the cat. Brain Res 509:325-327. 
Villa AE, Rouiller EM, Simm GM, Zurita P, De RY, De RF (1991) Corticofugal modulation of the information processing in the auditory thalamus of the cat. Exp Brain Res 86:506-517.

Villa AE, Tetko IV, Dutoit P, De RY, De RF (1999) Corticofugal modulation of functional connectivity within the auditory thalamus of rat, guinea pig and cat revealed by cooling deactivation. J Neurosci Methods 86:161-178.

Volgushev M, Kudryashov I, Chistiakova M, Mukovski M, Niesmann J, Eysel UT (2004) Probability of transmitter release at neocortical synapses at different temperatures. J Neurophysiol 92:212-220.

von der Behrens W, Bauerle P, Kossl M, Gaese BH (2009) Correlating stimulus-specific adaptation of cortical neurons and local field potentials in the awake rat. $\mathrm{J}$ Neurosci 29:13837-13849.

Winer JA, Diehl JJ, Larue DT (2001) Projections of auditory cortex to the medial geniculate body of the cat. J Comp Neurol 430:27-55.

Winer JA, Kelly JB, Larue DT (1999) Neural architecture of the rat medial geniculate body. Hear Res 130:19-41.

Winkler I, Denham SL, Nelken I (2009) Modeling the auditory scene: predictive regularity representations and perceptual objects. Trends Cogn Sci 13:532-540.

Yu XJ, Xu XX, He S, He J (2009) Change detection by thalamic reticular neurons. Nat Neurosci 12:1165-1170. 
a

Warm

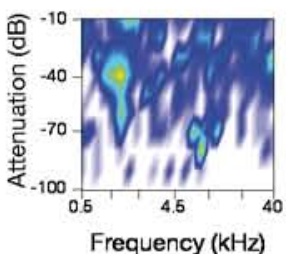

d
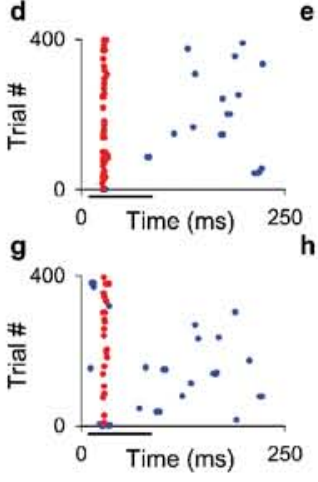

j

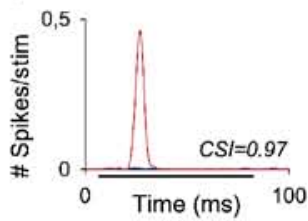

k
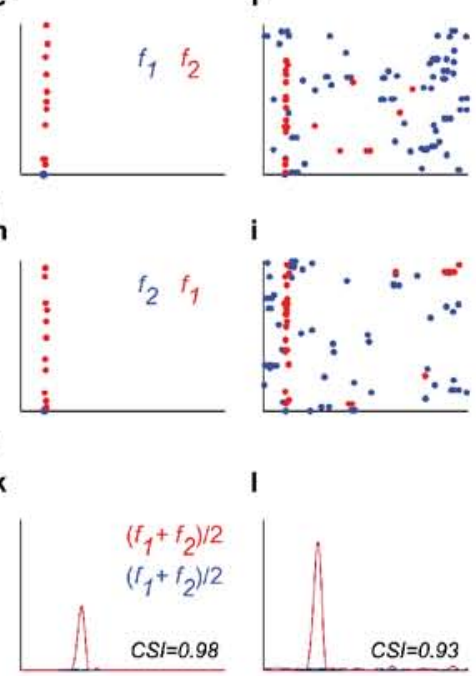

Recovery

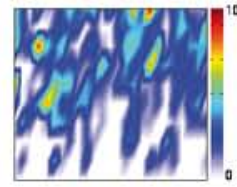

f

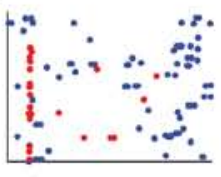

i

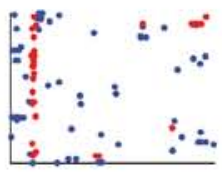

m



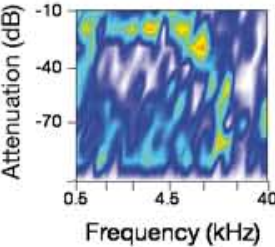

p$$
\text { 非 }
$$$$
\text { 要 }
$$$$
\text { ह }
$$

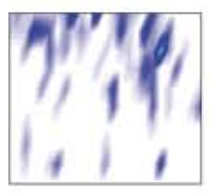

o

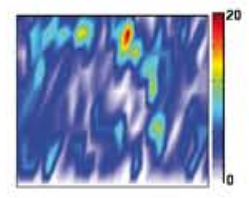

q

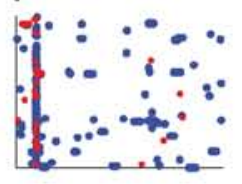

r

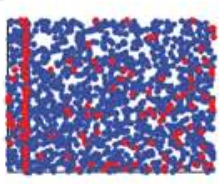

u
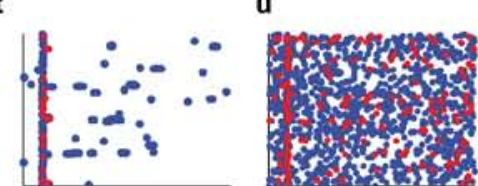

w

x 


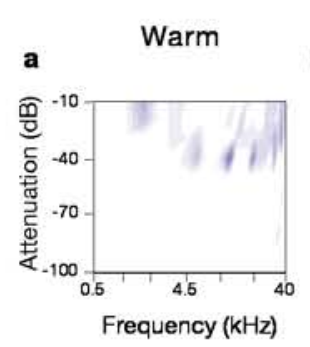

b Cool

c Recovery
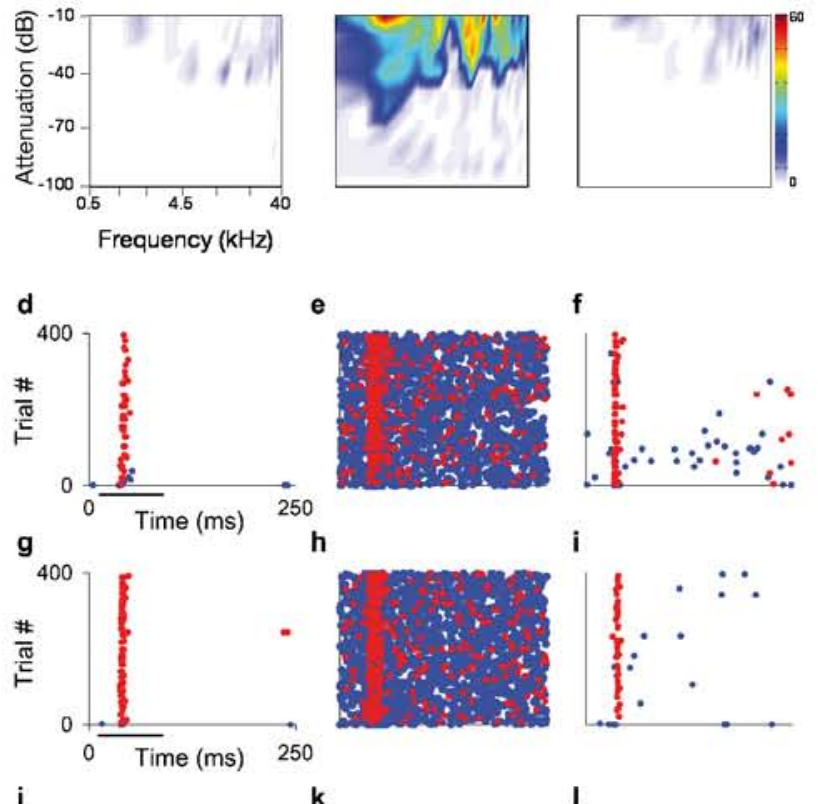

$$
\text { j }
$$
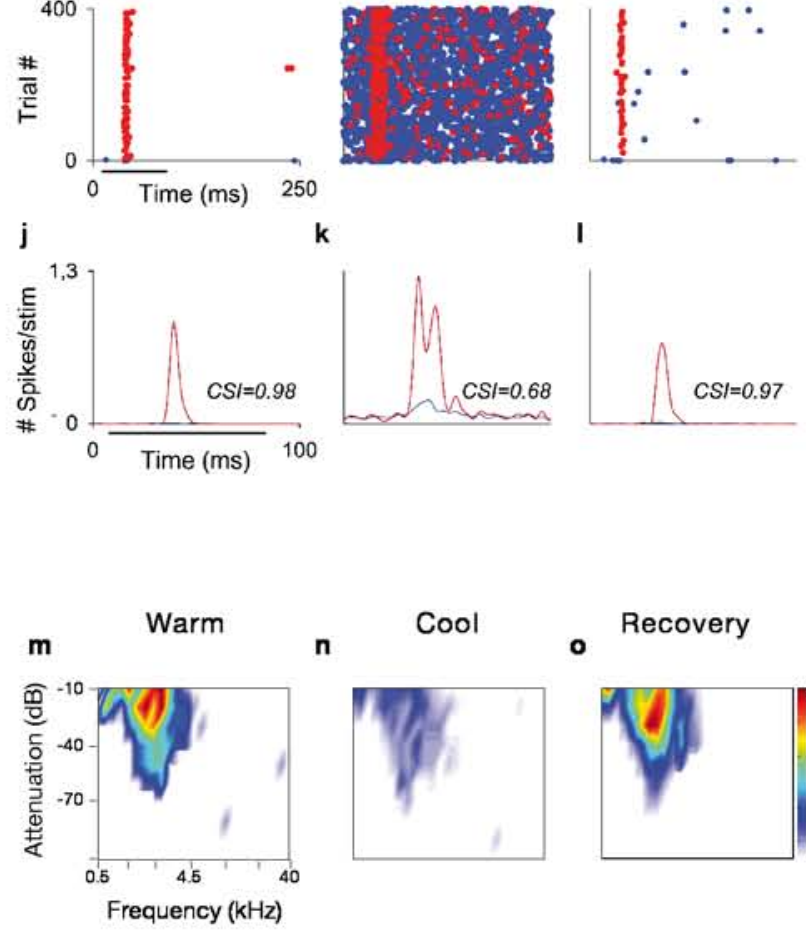

o

Recovery
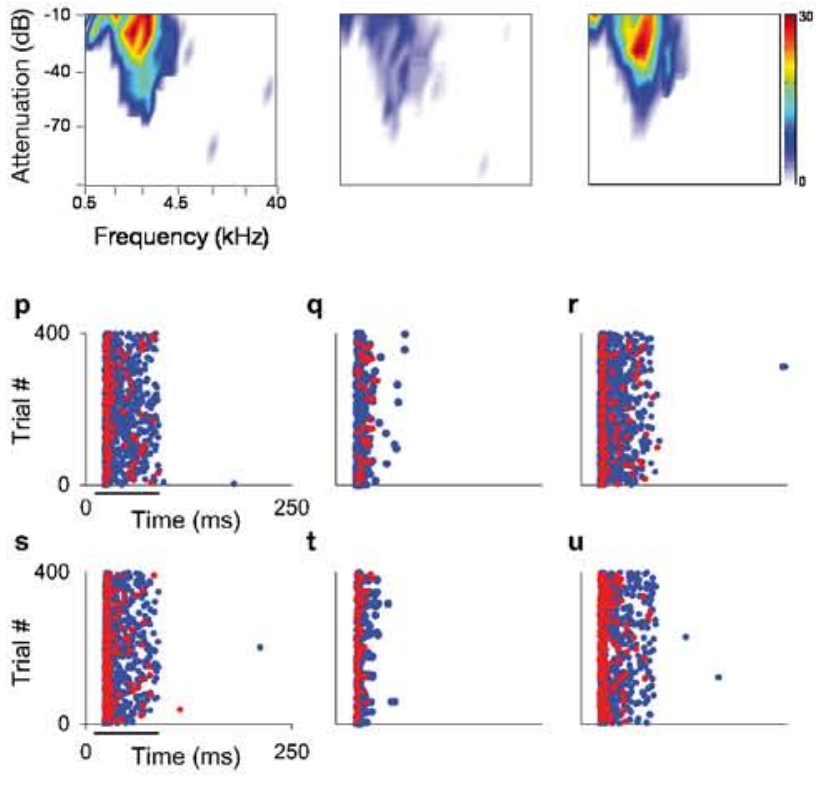

$$
\text { ह }
$$
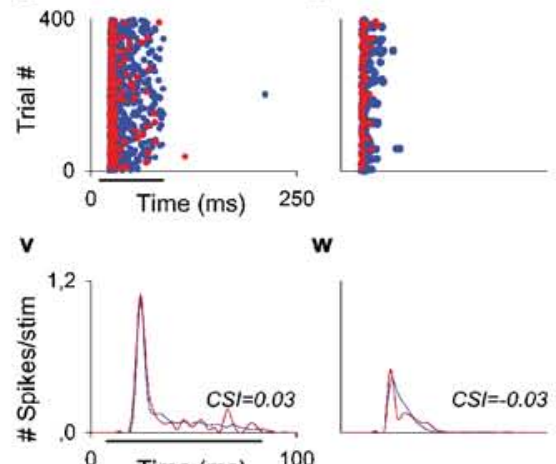

W
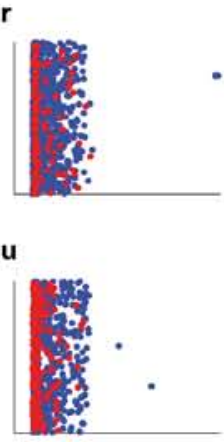

x 
Warm Transitional cooling

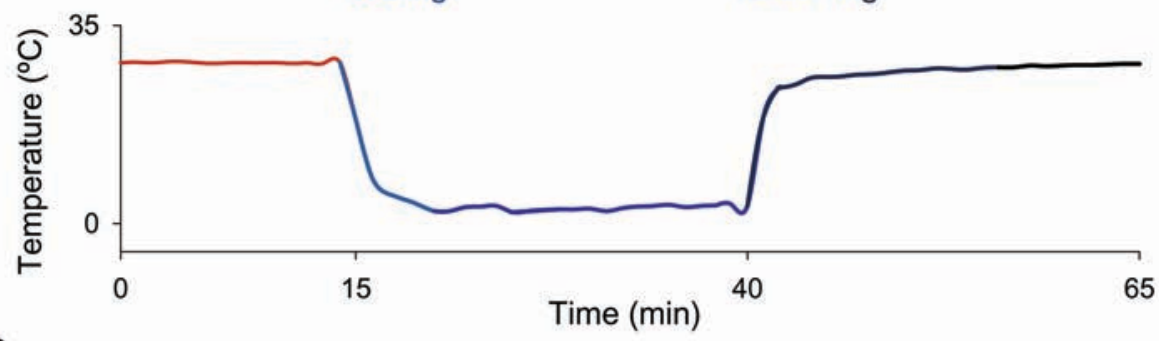

b
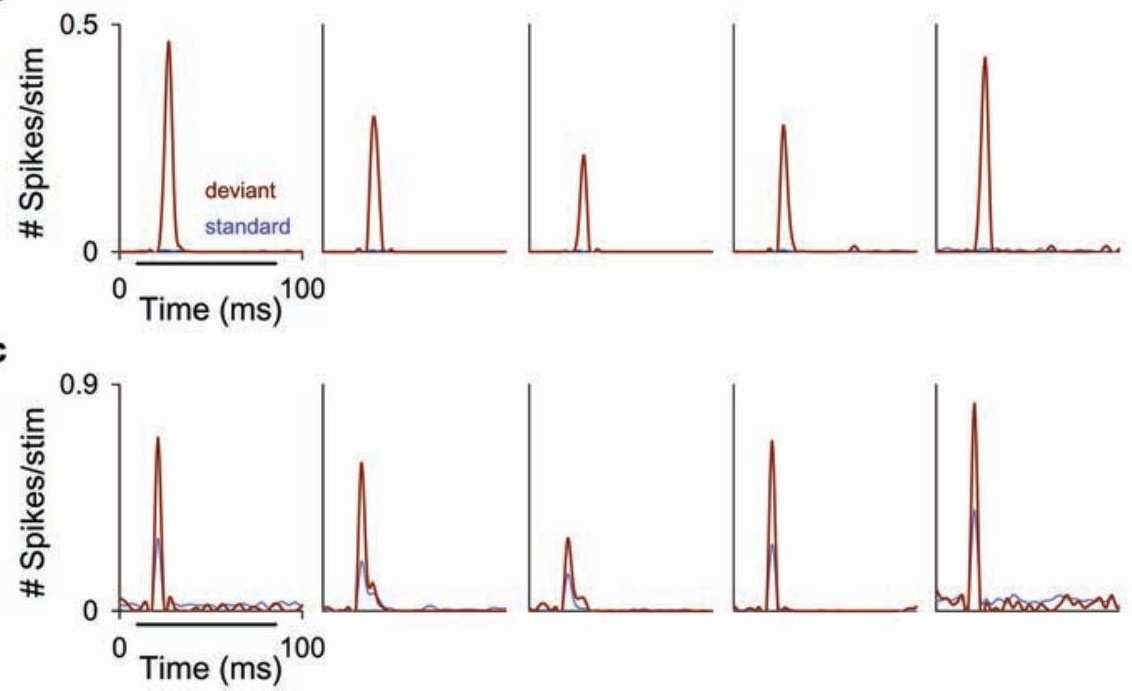

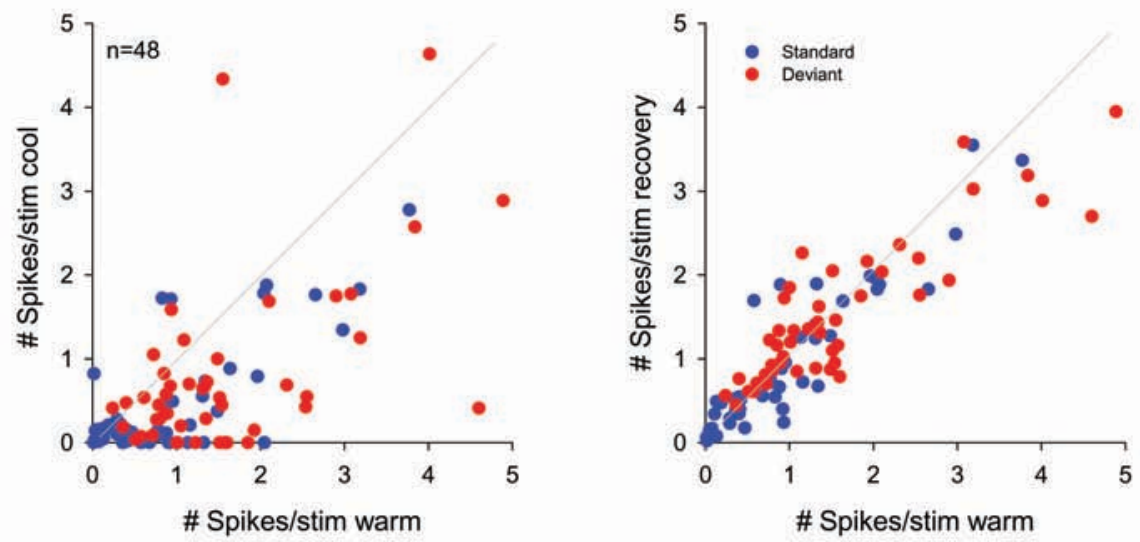

C
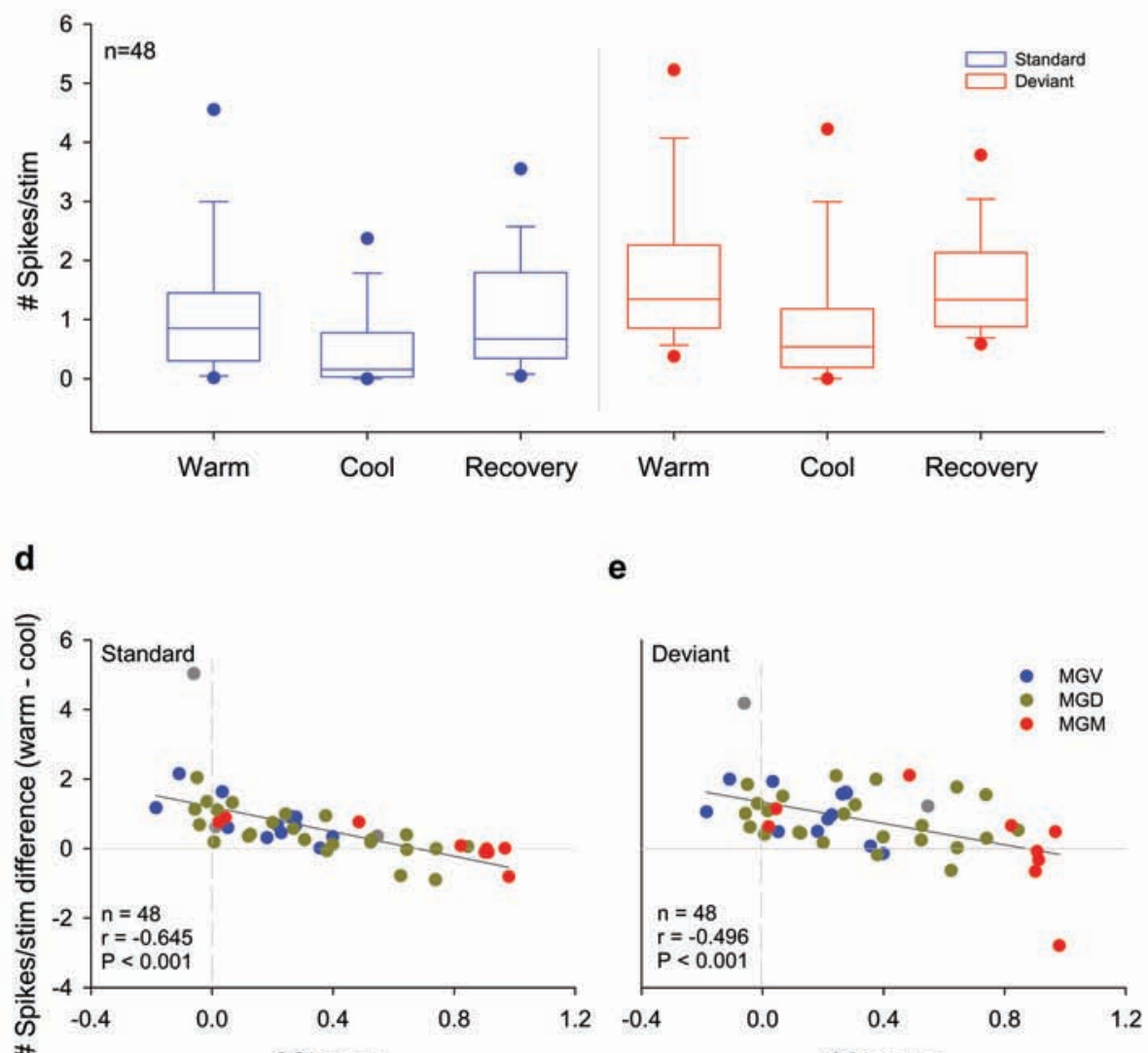

CSI warm

CSI warm 
